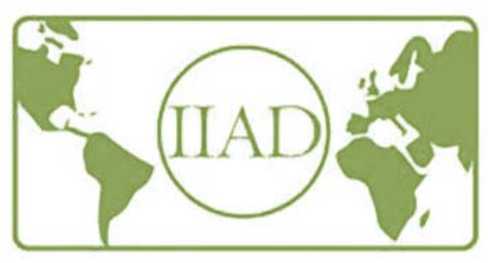

\title{
STARCH-PROTEIN \\ ACTIVE FILMS FOR \\ FOOD PRESERVATION
}

DOCTORAL THESIS

Olga Moreno Marro

Supervisors

Amparo Chiralt Boix

Lorena Atarés Huerta

Valencia, Febrero 2017 


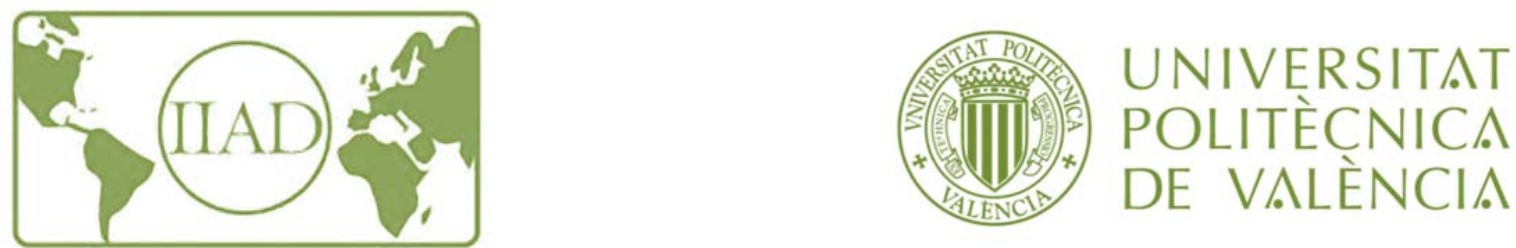

Dra. Amparo Chiralt Boix, Catedrática de Universidad, perteneciente al Departamento de Tecnología de Alimentos de la Universitat Politècnica de València.

Dra. Lorena Atarés Huerta, Profesora Titular de Universidad, perteneciente al Departamento de Tecnología de Alimentos de la Universitat Politècnica de València.

Hacen constar que:

La memoria titulada "STARCH-PROTEIN ACTIVE FILMS FOR FOOD PRESERVATION" que presenta $D^{a}$ Olga Moreno Marro para optar al grado de Doctor por la Universitat Politècnica de València, ha sido realizada en el Instituto de Ingeniería de Alimentos para el Desarrollo (IuIAD - UPV) bajo su dirección y que reúne las condiciones para ser defendida por su autora.

Valencia, 15 de Febrero 2017

Fdo. Amparo Chiralt Boix

Fdo. Lorena Atarés Huerta 

A la meua familia 

A trompellots, i quasi amb els ulls tancats, done els últims passos, mentres deixe caure la motxilla. Adolorida. Esgotada. Amb una set desesperada. Em tombe a terra, sentint totes les pedres del camí clavant-se a la meua esquena i com el meu cor batega apressuradament. M'incorpore i obric els ulls. Ara que he arribat al cim de la muntanya, pareix que l'espessa boira que m'ha acompanyat tot el cami, sense deixar-me veure on estava la fi, finalment desapareix.

Comence a veure-ho tot amb claredat. Tots aquells trams que $m^{\prime}$ han semblat tan durs, ara apareixen en perfecta sintonia amb el seu voltant, amb tot el paisatge, $i$ amb la resta de camins que he fet en companyia. Totes aquelles mans amigues dispostes a donar-me l'espenta a voltes necessària, a oferir-me un glop d'aigua, o a portar la meua motxilla una estona. Ara veig que no ha hagut temps perdut. Que no he escollit rutes equivocades. Que res ha estat un error. Cada pas endavant $m$ 'ha dut més a prop de valls que ara no escolliria no veure. I al final de tot camí tortuós, sempre he trobat on descansar, agafar alè, i continuar fent marxa.

L'aire fresc de la muntanya em toca la cara mentres una llàgrima fugida em recorre la galta. Pot ser siga l'aire, o pot ser siga l'alegria d'una fi aconseguida.

De sobte veig que allà on he deixat la motxilla les brosses dibuixen el principi d'un nou camí. La boira, pràcticament desapareguda, ara deixa veure com realment no em trobe al cim de la muntanya, sinó a la vall d'una altra encara més gran.

I torne a sentir les ganes de caminar. 

he structure of this Doctoral Thesis is divided into five sections: Introduction, Objectives, Chapters, General Discussion and Conclusions. The Introduction discusses the current situation in biodegradable packaging, focusing on starch applications as food packaging material, blended with proteins and/or oxidized, and containing different active agents. In the Objective section, the general and specific objectives of the Thesis are detailed. The five Chapters correspond to different scientific publications and present the obtained results organized in the usual sections: introduction, materials and methods, results and discussion and conclusion. The General Discussion section summarizes the most relevant results thoroughly analysed in every Chapter, from an overall perspective. Finally, the last section presents the most relevant conclusions of the Doctoral Thesis.

In accordance with the defined objectives, biodegradable active films based on starch/protein blends were obtained; the effect of the introduction of buttermilk powder (BM), enzymes (lactoferrin (LF) and/or lysozyme (LZ)) and bovine gelatin (BG) on the active and functional properties of the films was analysed, in terms of their suitability for food packaging applications. The influence of the differing film processing methods was also considered for some film formulations. Ethyl lauroyl arginate (LAE) was incorporated as antimicrobial compound and its interactions with the polymer matrix and its effect on the films' functional and antimicrobial properties were analysed. The oxidation of starch to reinforce the polymeric network by the crosslinking effect with gelatin was also evaluated. The obtained films were characterized as to their functional properties as food packaging material, as well as to their antimicrobial and/or antioxidant ability for food preservation in different food systems. The obtained results are organized in the following Chapters:

Chapter 1 is entitled "Physical and bioactive properties of corn starch - buttermilk edible films" and deals with the effect of incorporating different ratios of both non-heated and heated BM on the properties of corn starch films. The obtained films showed a heterogeneous structure, although a protein gel was formed when BM dispersion was heated with starch. Heat treatment enhanced tensile and barrier properties, and conferred antioxidant activity on the films, although no antilisterial activity was observed for any film containing BM. 
Chapter 2, entitled "Effect of the incorporation of antimicrobial/antioxidant proteins on the properties of potato starch films", analyses the influence of the incorporation of different ratios of LF and/or LZ into potato starch films on their structural, thermal, physical and active properties. Both enzymes showed a partial compatibility with starch, which affected the microstructure and tensile properties of the films. The formation of a globular protein layer at the top of the films enhanced their barrier properties. Although only the films with LF/LZ blend reduced the growth of coliforms in minced pork meat, due to their synergistic action, all of the films tested were effective at controlling the lipid oxidation progress in pork lard.

In Chapter 3, "Influence of the processing method and antimicrobial agents on properties of starch-gelatin biodegradable films", the effect of LZ or LAE incorporation into corn starch-BG blend films was analysed, in terms of their structural, thermal, physical and active properties. Films were obtained by both casting and thermoprocessing methods, leading to a stratified structure or separate domains of both polymers, respectively, due to the phase separation. The incorporation of $L Z$, but mainly that of LAE, enhanced the compatibility between polymers, but they had an opposite effect on barrier properties. Casting films exhibited better barrier properties, while thermoprocessed films were less rigid and resistant and more stretchable. All of the films containing LAE showed intense antilisterial activity.

Chapter 4, entitled "Influence of starch oxidation on the functionality of starch-gelatin based active films", analyses the effect of the periodate oxidation of corn starch on properties of the starch-BG blend films, with and without LAE, obtained by casting. The structural and functional properties of the films, as affected by the carbonyl-amino crosslinking, were analysed. The films showed a higher polymer compatibility and improved tensile and barrier properties, with lower water uptake capacity. However, film browning, due to the formation of Maillard compounds, was observed. LAE incorporation affected crosslinking and the films' properties, due to its bi-functional character (carbonyl-amino). Crosslinking processes progressed throughout storage time, leading to an increase in mechanical resistance and browning of the films.

Chapter 5 analyses the "Application of the active films containing LAE on real foods: marinated salmon and chicken breast fillets". The Maillard compounds formed in films with oxidized starch conferred antimicrobial capacity on the films, which increased with the storage time. Blend films of oxidized starch and BG, with and without $1.3 \%$ of LAE, were effective at controlling microbial growth in marinated salmon fillets throughout 45 days of storage, even when inoculated with Listeria innocua. Blended films of native or 
oxidized starch and BG, with and without $10 \%$ of $\mathrm{LAE}$, were applied to vacuum packaging of chicken breast fillets. Although samples packaged with films containing oxidized starch showed higher antimicrobial effectiveness than those films containing native starch, they also promoted the lipid oxidation of the chicken breast fillets. On the contrary, native starch based films did not promote meat oxidation and were also effective at extending the shelf-life of chicken breast fillets. 


\section{DISEMINATION OF RESULTS}

\section{International Journals JCR}

\section{Published}

"Physical and bioactive properties of corn starch - Buttermilk edible films". O. Moreno, C. Pastor, J. Muller, L. Atarés, C. González, A.Chiralt (2014). Journal of Food Engineering 141, 27-36.

"Effect of the incorporation of antimicrobial/antioxidant proteins on the properties of potato starch films". O. Moreno, L. Atarés, A. Chiralt. (2015) Carbohydrate Polymers 133, 353-364.

"Influence of the processing method and antimicrobial agents on properties of starchgelatin biodegradable films". O. Moreno, R. Díaz, L. Atarés, A. Chiralt. (2016) Polymer international.

\section{Submitted}

"Influence of starch oxidation on the functionality of starch-gelatin based active films". O. Moreno, J. Cárdenas, L. Atarés, A. Chiralt. Carbohydrate Polymers.

"Starch-gelatin antimicrobial packaging materials to extend the shelf life of chicken breast fillets" O. Moreno, L. Atarés, A. Chiralt, M. Cruz-Romero, J. Kerry. Food Control.

"Active starch-gelatin films for shelf-life extension of marinated salmon". O. Moreno, À. Gil, L. Atarés, A. Chiralt. LWT- Food Science and Technology.

\section{Communication in International Congresses}

"Propiedades físicas y antioxidantes de películas comestibles de almidón de maíz y suero de mantequilla". O. Moreno, C. Pastor, J. Muller, L. Atarés, C. González, A.Chiralt. $9^{\circ}$ CIBIA, ISBN 978-84-9048-168-4 Vol. 3 (474-482). València (2014).

Poster and Article. 
"Efecto de la incorporación de lactoferrina y lisozima sobre las propiedades físicas de películas biodegradables de almidón de patata". O. Moreno, L. Atarés, A. Chiralt. Foodlnnova 2014. ISBN 978-950-698-376-5. Entreríos, Argentina.

Poster and Article.

"Antimicrobial properties of potato starch biodegradable films containing lactoferrin and Iysozyme". O. Moreno, L. Atarés, A. Chiralt. VIII Congreso CYTA-CESIA. 2015, Badajoz, Spain.

Poster.

"Antimicrobial films based on starch-gelatine and lysozyme". O. Moreno, L. Atarés, A. Chiralt. 3rd international meeting on Material/Bioproduct Interaction. Matbim 2015, Zaragoza., Spain.

Poster.

"Starch-gelatin biodegradable films containing LAE or lyzozyme as antimicrobial agents" O. Moreno, R., Díaz, L. Atarés, A. Chiralt. 5th Intenational Conference on Biobased and Biodegradable Polymers, Biopol 2015. Donostia, Spain.

Poster.

"Effect of starch oxidation on the functional properties and migration of blend films with gelatin". O. Moreno, J. Cárdenas, L. Atarés, A. Chiralt. 6th International Symposium on Food Packaging: Scientific Developments Supporting Safety and Innovation, ILSI, 2016. Barcelona, Spain.

Poster.

"Increasing shelf-life of marinated salmon with oxidized starch-gelatin active films". O. Moreno, À. Gil, L. Atarés, A. Chiralt. International conference on Food, Foodlnnova 2017. Cesena, Italy.

Poster. 


\section{Communication in scientific events}

"Películas biodegradables a base de almidón con propiedades antioxidantes y antimicrobianas para su aplicación en alimentos". O., Moreno. II Encuentro de estudiantes de Doctorado de la UPV (2015). Universitat Politècnica de València, Valencia, Spain.

Poster and oral communication.

\section{PREDOCTORAL STAYS AT FOREIGN INSTITUTIONS}

Application of different packaging strategies based on starch-gelatin blends for chicken breast fillets preservation. School of Food and Nutritional Sciences, Food Packaging Group, University College Cork (UCC), Cork, Ireland. From May 2016 to August 2016, under the supervision of Joseph Kerry. 


\section{TABLE OF CONTENTS}

\section{INTRODUCTION}

1.1. Current situation of food packaging

1.2. Biodegradable polymers for food packaging

1.3. Strategies for improving properties of starch films used in the present study

1.3.1. Starch oxidation

1.3.2. Starch-protein blend films

1.4. Active biodegradable films for food packaging

1.4.1. Use of lactoferrin, lysozyme and ethyl lauroyl arginate (LAE) as antimicrobial compounds

2. OBJECTIVES

3. CHAPTERS

CHAPTER 1 Physical and bioactive properties of corn starch - buttermilk edible films

CHAPTER 2 Effect of the incorporation of antimicrobial/antioxidant proteins on the properties of potato starch films

CHAPTER 3 Influence of the processing method and antimicrobial agents on properties of starch-gelatin biodegradable films

CHAPTER 4 Influence of starch oxidation on the functionality of starch-gelatin based active films

CHAPTER 5 Active starch-gelatin films for shelf-life extension of marinated salmon

Starch-gelatin antimicrobial packaging materials to extend the shelf life of chicken breast fillets 

he overall objective of the doctoral thesis was the development of starch-based (S) biodegradable active films for food packaging applications, by applying both casting method and thermoprocessing. Different blends of $S$ with protein material have been studied in order to improve the functional properties of the films or confer antimicrobial/antioxidant activity. The following protein materials were used: powder buttermilk (BM); lactoferrin (LF) and/or lysozyme (LZ), and bovine gelatin (BG). Ethyl lauroyl arginate (LAE, E243) was also incorporated as antimicrobial compound. Likewise, S:BG blend films, either with or without LAE, with previously oxidized S, have been studied to enhance the crosslinking of polymer chains and to improve the film properties. The films have been characterized as to their functional properties as packaging material, their antioxidant and/or antimicrobial properties, as well as their capacity for preserving different food systems, in terms of lipid oxidation and microbial spoilage.

Blends of $S$ with BM gave rise to films with a heterogeneous structure, in which the formation of a protein gel was observed when BM dispersion was heated with $\mathrm{S}$ at $90^{\circ} \mathrm{C}$ for $30 \mathrm{~min}$. The heat treatment promoted an increase in the resistance to break and stretchability of films, together with a decrease in water vapour permeability. Only those films subjected to heat treatment exhibited antioxidant activity, probably due to the release of active peptides as a result of high temperatures. However, no antilisterial activity was observed for any film containing BM.

The incorporation of LF and/or LZ into S films, obtained by the casting method, led to a partial compatibility between polymers, thus affecting the microstructure of $S$ films, as well as leading to an rise in the glass transition temperature. Films with proteins were less extensible, especially when LF was incorporated. All of the films tested were effective at controlling the progress of lipid oxidation in pork lard, whereas only films with LF/LZ blend reduced the growth of coliforms in minced pork meat, as a result of their synergistic action.

Films based on $S$ and BG blends (1:1) were obtained by both casting method and thermo-processing. Phase separation of both polymers (stratified structure or separated 
domains of both polymers, respectively) was observed in both cases. The incorporation of $L Z$, but mainly $L A E$, into films, enhanced the compatibility between polymers. Thermoprocessed films were more permeable to water vapour and oxygen, less rigid and resistant and more stretchable, in comparison with those films obtained by casting. While LAE incorporation improved the water vapour barrier capacity, it worsened the oxygen barrier properties, contrary to the effect produced by LZ. All films with LAE exhibited high antilisterial activity.

Films based on oxidized S and BG (1:1), obtained by casting, showed a high polymer compatibility, and crosslinking between the polymer chains occurred due to the carbonylamino condensation reaction. As a result, the water uptake ability of the films decreased and the mechanical and barrier properties improved, although film browning was induced due to the formation of Maillard compounds. LAE incorporation implied its involvement in condensation reactions, due to its bi-functional character (carbonyl-amino), thus affecting crosslinking and the film properties. These reactive processes progressed throughout storage time, leading to an increase in the mechanical resistance and browning of the films. The obtained Maillard compounds conferred antimicrobial capacity on the films, which increased as the storage time progressed.

The application of blend films of native or oxidized $S$ and BG with LAE, for the purposes of preserving vacuum packaged chicken breast fillets, extended the shelf-life through the inhibition of bacterial growth (total viable counts; psicrotrophic, anaerobic,lactic acid bacteria and coliforms). Samples packaged in non-oxidized S films, showed total viable counts that were lower than the established legal limit (106 CFU/g) up to 16 days; while those packaged in contact with oxidized $S$ did not reach the legal limit after 19 days of storage. Then, a combined effect of LAE and Maillard compounds was observed. Nonetheless, the hydrogen peroxide production, responsible for the antimicrobial activity of Maillard compounds, promoted the lipid oxidation of chicken fillets, which reached the maximum acceptability limit ( $1 \mathrm{mg} \mathrm{MDA} / \mathrm{kg}$ ) after 3 days of packaging in films containing LAE and oxidized $S$. Blend films of oxidized $S$ and $B G$, with and without $1,3 \%$ of LAE were also effective at controlling microbial growth in marinated salmon fillets throughout 45 days of storage. Both films, either with or without LAE, showed similar antilisterial activity in inoculated salmon samples. Therefore, blend films of oxidized starch and gelatin are promising packaging materials for the purposes of controlling microbial growth in foods that are not susceptible to oxidation. 
I objetivo general de la presente tesis doctoral se basa en el desarrollo de films activos biodegradables a base de almidón (S) para su aplicación en sistemas de envasado de alimentos, por medio de dos métodos diferentes de obtención, método en húmedo por extensión y secado (casting) y método en seco (termoprocesado). Se estudiaron mezclas de $S$ con diferentes materiales proteicos, con fin de disminuir la alta higroscopicidad de los films de $S$ y su retrogradación a lo largo del tiempo de almacenamiento y mejorar sus propiedades funcionales, así como conferirles actividad antimicrobiana/antioxidante. Los materiales proteicos utilizados fueron los siguientes: suero de mantequilla en polvo (BM); lactoferrina (LF) y/o lisozima (LZ), y gelatina bovina (BG). El etil lauroil arginato (LAE, E243) fue también incorporado como compuesto antimicrobiano. Asimismo, se estudiaron los films mezcla de $S$ con BG, con y sin LAE incorporado, habiendo oxidado previamente el $S$, para así potenciar el entrecruzado de las cadenas poliméricas y mejorar las propiedades de los films. Estos fueron caracterizados en sus propiedades funcionales como material de envase, sus propiedades antioxidantes y/o antimicrobianas, así como por su capacidad de conservación de diferentes sistemas alimentarios, en términos de su oxidación lipídica y deterioro microbiológico.

Las mezclas de $\mathrm{S}$ con BM dieron lugar a películas con una estructura heterogénea, en las que se observó la formación de un gel proteico como resultado del calentamiento de la dispersión $\mathrm{BM}$ con $\mathrm{S}$ a $90{ }^{\circ} \mathrm{C}$ durante $30 \mathrm{~min}$. El tratamiento térmico promovió un aumento de la resistencia a la rotura y extensibilidad de los films, junto con una disminución en la permeabilidad al vapor de agua. Sólo las películas sometidas a tratamiento térmico y homogeneización con cizalla mostraron actividad antioxidante, probablemente debido a la liberación de péptidos activos en consecuencia de la alta temperatura y fuerza de cizalla aplicada Sin embargo, no se observó actividad antilisteria para ninguno de los films con BM.

La incorporación de LF y/o LZ en films de $S$ condujo a una compatibilidad parcial entre polímeros, afectando así a la microestructura de los films de $\mathrm{S}$, y produciendo un aumento de la temperatura de transición vítrea y disminución de la capacidad de 
alargamiento de los films, especialmente cuando se incorporó LF. Todos los films resultaron eficaces en el control del progreso de la oxidación lipídica de la manteca de cerdo, mientras que sólo las películas con mezcla LF/LZ redujeron el crecimiento de coliformes en carne picada de cerdo, como resultado de su acción sinérgica.

Los films basados en la mezcla S y BG (1: 1) fueron obtenidos por casting y termomoldeado y compresión, llevando a la separación de fases entre ambos polímeros (estructura esratificada o separación de dominios de ambos polímeros, respectivamente). La incorporación de $L Z$, y principalmente de $L A E$, en los films, aumentó la compatibilidad entre ambos polímeros. Los films termoprensados fueron más permeables al vapor de agua y al oxígeno, menos rígidos y resistentes y más extensibles, en comparación con aquellos obtenidos por casting. La incorporación de LAE mejoró la capacidad de barrera contra el vapor de agua, mientras que incurrió en un empeoramiento de la barrera frente al oxígeno, contrariamente al efecto producido por la LZ. Los films con LAE, moldeados o termoprensados, mostraron una alta eficacia antilisteria.

Los films basados en S oxidado y BG (1: 1), fueron obtenidos por casting y mostraron una alta compatibilidad polimérica, lo cual condujo al entrecruzado de las cadenas como resultado de la reacción de condensación carbonilo-amino producida entre ambos polímeros. En consecuencia, la capacidad de absorción de agua de los films disminuyó y se mejoraron las propiedades mecánicas y de barrera, aunque también se indujo a un pardeamiento de los films, indicando a la formación de compuestos de Maillard. La incorporación de LAE implicó su participación en las reacciones de condensación, debido a su carácter bi-funcional (carbonilo-amino), lo que afectó al entrecruzado y las propiedades de los films. Estos procesos reactivos progresaron a lo largo del tiempo de almacenamiento, dando lugar a un aumento de la resistencia mecánica y pardeamiento de los films. Los compuestos de Maillard obtenidos también confirieron capacidad antimicrobiana a los films, coherentemente con el tiempo de almacenamiento.

La aplicación de films basados en $\mathrm{S}$ nativo u oxidado, en sus mezclas con BG, y con la incorporación de $\mathrm{LAE}$, para la conservación de filetes de pechuga de pollo envasados a vacío, condujo a una prolongación de la vida útil por medio de la inhibición del crecimiento bacteriano, en términos de recuentos de viables totales, bacterias psicrotróficas, anaeróbicas y de ácido láctico, y coliformes. Las muestras envasadas con films con $S$ nativo, mostraron recuentos de viables totales inferiores al límite legal establecido ( $\left.10^{6} \mathrm{UFC} / \mathrm{g}\right)$, hasta 16 días de envasado; mientras que aquellas que fueron envasadas en contacto con $S$ oxidado no alcanzaron el límite legal en 19 días de 
almacenamiento. Se observó, entonces, un efecto combinado entre el LAE y los compuestos de Maillard formados. La capacidad antimicrobiana de dichos compuestos fue atribuida a la capacidad de producción de peróxido de hidrógeno, que incurrió en la oxidación lipídica de los filetes de pollo, los cuales alcanzaron el nivel máximo de aceptabilidad ( $1 \mathrm{mg}$ MDA / $\mathrm{kg}$ ) después de 3 días de envasado en contacto con films que contenían LAE y $S$ oxidado. Los films basados en $S$ oxidado en su mezcla con BG y con 200 ppm de LAE (con respecto al producto alimenticio) fueron también eficaces en la conservación de los filetes de salmón marinado durante 45 días de almacenamiento. Ambas formulaciones, con o sin LAE, mostraron actividad antilisteria in vitro. 
'objectiu general de la tesi doctoral és el desenvolupament de films actius biodegradables a base de midó (S) per a la seua aplicació en sistemes d'envasat d'aliments, amb l'utitització del mètode d'extensió i assecat (casting) i termoprocessat (barrejat en fos i termo-compressió). Es van estudiar barreges de $\mathrm{S}$ amb diferents materials proteics, per millorar les propietats funcionals dels films o conferir activitat antimicrobiana. Els materials protèics utilitzats van ser: sèrum de mantega en pols (BM); lactoferrina (LF) i/o lisozima (LZ), i gelatina bovina (BG). L'ètil lauroil arginat (LAE, E243) va ser també incorporat com a compost antimicrobià. Així mateix, es van estudiar els films barreja de $S$ amb BG, amb i sense LAE, havent oxidat prèviament el $S$, per potenciar l'entrecreuat de les cadenes polimèriques i millorar les propietats dels films. Aquests van ser caracteritzats en les seues propietats funcionals com a material d'envàs, les seues propietats antioxidants i/o antimicrobianes, així com en la seua capacitat de conservació en diferents sistemes alimentaris, en termes de la seua oxidació lipídica i deteriorament microbià.

Les barreges de $\mathrm{S}$ amb BM van donar lloc a films amb una estructura heterogènia, en què es va observar la formació d'un gel protèic com a resultat del calfament de la dispersió $\mathrm{BM}$ amb $\mathrm{S}$ a $90{ }^{\circ} \mathrm{C}$ durant $30 \mathrm{~min}$. El tractament tèrmic va promoure un augment de la resistència al trencament i extensibilitat dels films, juntament amb una disminució en la permeabilitat al vapor d'aigua. Només el films sotmesos a tractament tèrmic van mostrar activitat antioxidant, probablement a causa de l'alliberament de pèptids actius com a conseqüència de l'alta temperatura. No obstant això, no es va observar activitat antilisteria per cap dels films amb BM.

La incorporació de LF i/o LZ en films de $S$ obtinguts per casting va donar lloc a una compatibilitat parcial entre polímers, afectant a la microestructura dels films de $\mathrm{S}$, i produint un augment de la temperatura de transició vítria. Els films amb les proteïnes van ser menys extensibles, especialment quan es va incorporar LF. Tots els films van resultar eficaços en el control de l'oxidació lipídica de la mantega de porc, mentre que només el films amb barreja LF/LZ van reduir el creixement de coliforms en carn picada de porc, com a resultat de la seua acció sinèrgica. 
Els films amb barreges S i BG (1: 1) van ser obtinguts per casting i termo-processat. En tots dos casos es va observar separació de fases entre els dos polímers (estructura estratificada o separació de dominis d'ambdós polímers, respectivament). La incorporació de LZ, i principalment de LAE, en els films, va augmentar la compatibilitat entre tots dos polímers. Els films termo-processats van ser més permeables al vapor d'aigua i l'oxigen, menys rígids i resistents i més extensibles, en comparació amb els obtinguts per càsting. La incorporació de LAE va millorar la capacitat de barrera al vapor d'aigua, a l'hora que va disminuir la capacitat de barrera davant l'oxigen, contràriament a l'efecte produït per la LZ. Tots els films amb LAE, van mostrar una alta capacitat antilisteria.

Els films amb S oxidat i BG (1: 1), van ser obtinguts per casting i van mostrar una alta compatibilitat dels polímers, tot produint entrecreuat de les cadenes com a resultat de la reacció de condensació carbonil-amino. En conseqüència, va disminuir la capacitat d'absorció d'aigua dels films i es van millorar les propietats mecàniques i de barrera, encara que es va promoure l'enfosquiment dels films, cosa que indica la formació de compostos de Maillard. La incorporació de LAE va implicar la seua participació en les reaccions de condensació, a causa del seu caràcter bi-funcional (carbonil-amino), el que va afectar a l'entrecreuat i les propietats dels films. Aquests processos reactius van progressar al llarg del temps d'emmagatzematge, donant lloc a un augment de la resistència mecànica i enfosquiment dels films. Els compostos de Maillard formats van conferir capacitat antimicrobiana als films, la qual va augmentar amb el temps d'emmagatzematge.

L'aplicació de films barreja de $S$ natiu o oxidat i BG, amb LAE, per a la conservació de filets de pit de pollastre envasats al buit, va prolongar la seua vida útil en termes del creixement bacterià (recomptes de viables totals, bacteris psicrotrófiques, anaeròbiques, de l'àcid làctic, i coliformes). Les mostres envasades amb films de $\mathrm{S}$ natiu, van mostrar recomptes de viables totals inferiors al límit legal establert $\left(10^{6} \mathrm{UFC} / \mathrm{g}\right)$, fins a 16 dies; mentre que les envasades en contacte $a m b S$ oxidat no van arribar al límit legal en 19 dies d'emmagatzematge. Per tant, es va observar un efecte antimicrobià combinat del LAE i els compostos de Maillard formats. No obstant això, la producció de peròxid d'hidrogen, responsable de la capacitat antimicrobiana d'aquests compostos, va provocar l'oxidació lipídica dels filets de pollastre, els quals van aconseguir el nivell màxim d'acceptabilitat ( $1 \mathrm{mg} \mathrm{MDA} / \mathrm{kg}$ ) després de 3 dies d'envasat per a les mostres envasades en els films amb LAE i $S$ oxidat. Els films de $S$ oxidat i BG amb o sense 1.3 $\%$ de LAE van ser també eficaços en el control del creixement microbià en filets de salmó marinat durant 45 dies d'emmagatzematge. Totes dues formulacions, amb o 
sense LAE, van mostrar una activitat similar antilisteria en mostres de salmó inoculades.

Per tant, els films barreja de midó oxidat i gelatina són materials prometedors per al control del creixement microbià en aliments no sensibles a l'oxidació. 


\subsection{Current situation of food packaging}

ood packaging is becoming increasingly important in the food industry, where advances in functionality, such as convenience and portioning, are gaining more attention (Peelman et al., 2013). The overall goal of food packaging is to contain food in a cost-effective way that satisfies industry requirements and consumer desires, maintains food safety, and minimizes environmental impact (Marsh and Bugusu, 2007). More specifically, the primary function of the packaging is to isolate the foodstuff from the external environment, protecting it from the deterioration caused by spoilage microorganisms, chemical contaminants, oxygen, moisture, external mechanical force, etc., from the time of packaging to its delivery to the ultimate consumer (Majeed et al., 2013; Mihindukulasuriya and Lim, 2014; Rhim et al., 2013; Sung et al., 2013). Additionally, good food packaging should serve as a vehicle to incorporate food additives, namely antimicrobial or antioxidant compounds, thus contributing to food preservation, which constitutes the so-called active packaging (Dutta et al., 2006), as well as to facilitate communication to the consumers (Mihindukulasuriya and Lim, 2014). In consideration of these important functions, packaging has become the third largest industry in the world, and it represents about $2 \%$ of the Gross National Product (GNP) in developed countries (Han, 2005; Robertson, 2016).

Of the materials available for food packaging, the use of plastics has increased exponentially over the past two decades, as reflected by an annual growth of approximately $5 \%$ (Malathi et al., 2014). More specifically, worldwide annual plastic production was estimated to exceed 300 million tonnes by 2015 (Reddy et al., 2013), being about 59 million tonnes in Europe in 2014 (Plastic Europe - Association of plastics manufacturers, Plastics, the facts 2015). In fact, nowadays, plastic represents almost 40 $\%$ of the European packaging market (Figure I.1). 


\section{Market share of Food Packaging Material}

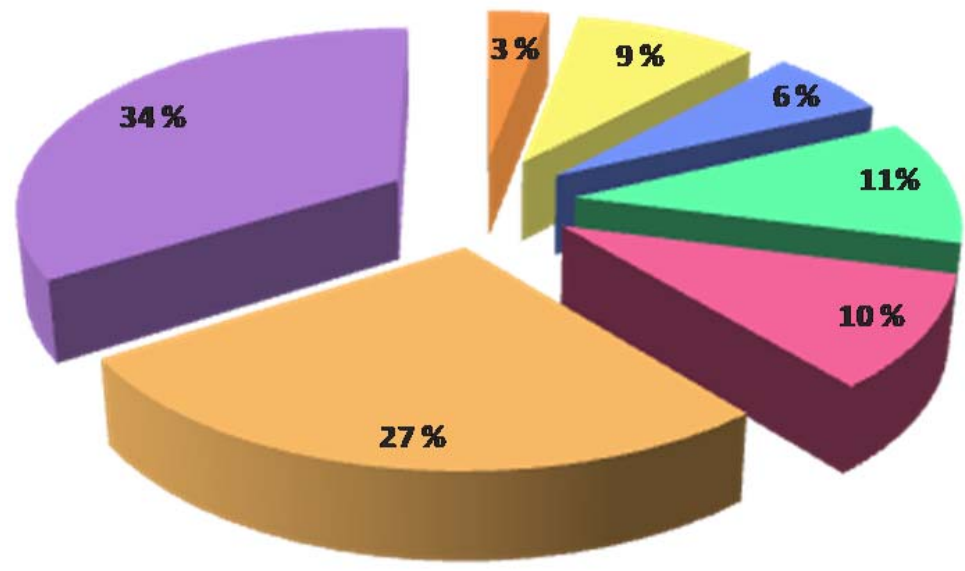

mother

Other metal

- Beverage cans

Glass

Flexible plastic

= Rigid plastic

- Paper and board

Figure I.1. Market share of Packaging Material. Source: Food Packaging Forum - Food Packaging Health, Food Packaging Materials.

Of plastic materials, petroleum-based plastics, such as polyethylene terephthalate (PET), polyvinylchloride $(P V C)$, polyethylene (PE), polypropylene (PP), polystyrene (PS) and polyamide (PA), are widely used as packaging material due to their ready availability at relatively low cost, good mechanical and barrier properties, thermo-processing ability and their chemical characteristics, making them suitable for food packaging (Siracusa et al., 2008). In terms of food packaging, it is mainly lightness and the ability to keep the food fresh and free of contaminant that are the reasons for the real success of petroleum-based plastics (Ferreira et al., 2016). However, despite the good properties of traditional plastics for food packaging, their use and accumulation imply huge environmental problems and dependence on fossil fuels, which are highly polluting (Sánchez-García et al., 2008). As much as $63 \%$ of the current plastic waste comes from packaging applications (GreenFacts - Report highlights), and it is estimated that less than $14 \%$ of plastic packaging materials are recyclable (Ferreira et al., 2016), since food packaging is often contaminated with foodstuffs or biological substances, which makes recycling either impractical or economically inconvenient (Siracusa et al., 2008). More precisely, the amount of plastic packaging generated in the municipal solid waste is on the rise and has severely damaging effects on the eco-system, water supplies, and sewer systems as well as the rivers and streams (Majeed et al., 2013). In particular, an increase of 0.1 to 13.7 million of tonnes from 1960 to 2005 was noticed (data obtained from EPA 2006a), and the recovery corresponding to these 13.7 million of tonnes was just $9.4 \%$ (Marsh and Bugusu, 2007). 
Taking both this scenario and the growing environmental awareness into account, much research work has been focused on the development of alternative packaging materials for the purposes of substituting petroleum-based plastics. Using biopackaging, namely biobased food packaging materials derived from renewable sources, which are biodegradable or compostable, is seen as a solution to the environmental problems derived from waste and a dependence on fossil fuels (Byun \& Kim, 2014; Cazón et al., 2016; De Moraes Crizel et al., 2016). In this sense, one of the challenges faced by the food packaging industry is to match the durability of biopackaging with the product shelflife, since the biologically based packaging materials must remain stable without any changes in their mechanical and/or barrier properties and must function properly during storage until disposal (Dutta et al., 2006).

\subsection{Biodegradable polymers for food packaging}

The current research lined focusing on the obtaining of packaging materials derived from renewable sources have given rise to the following, new concepts in the field of plastic packaging:

\section{Bioplastic}

Plastic made from biological or renewable resources, or able to be degraded by the action of micro-organisms, biological activity or both (European-Bioplastics - Bioplastic. Materials).

\section{Biobased plastic}

Plastic obtained totally or partially from biological resources, i.e. all or any of the monomers used in the synthesis are derived from biological resources (Vert et al., 2012).

\section{Degradable plastic}

A plastic which undergoes major structural changes under prescribed environmental conditions (Reddy et al., 2013).

\section{Biodegradable plastic}

Plastic able to be degraded by the action of micro-organisms, i.e. under appropriate conditions of moisture, temperature, and oxygen availability; biodegradation leads to the fragmentation or disintegration of the plastics with no toxic or environmentally harmful residue (Chandra et al., 1998; Vert et al., 2012). 
"Biobased plastic" and "biodegradable plastic" are often used interchangeably; however, they are not always linked concepts, since bioplastics can be made of $100 \%$-renewable material, biodegradable fossil-based polymers, or from a combination of both renewable and fossil material (Figure I. 2) (Reddy et al., 2013). On the other hand, biopolymers are those materials obtained from renewable biological resources and are biodegradable (Rhim et al., 2013). Synthetic packaging materials could be replaced by edible and biodegradable films in several applications, due to their ability to prevent moisture and aroma loss, solute transport, water absorption in the food matrix or oxygen penetration (Cazón et al., 2016). Furthermore, biopolymer packaging materials can act as carriers of a wide variety of bioactive compounds, such as antioxidants, antifungal agents, antimicrobials, or other nutrients, which could contribute to food preservation (SánchezGarcía et al., 2008).

As regards biobased polymers, they can be divided into three main categories on the basis of their origin and production (Byun and Kim, 2014; Dutta et al., 2006; Rhim et al., 2013), as described below, with especial emphasis on the starch and proteins used in the present study.

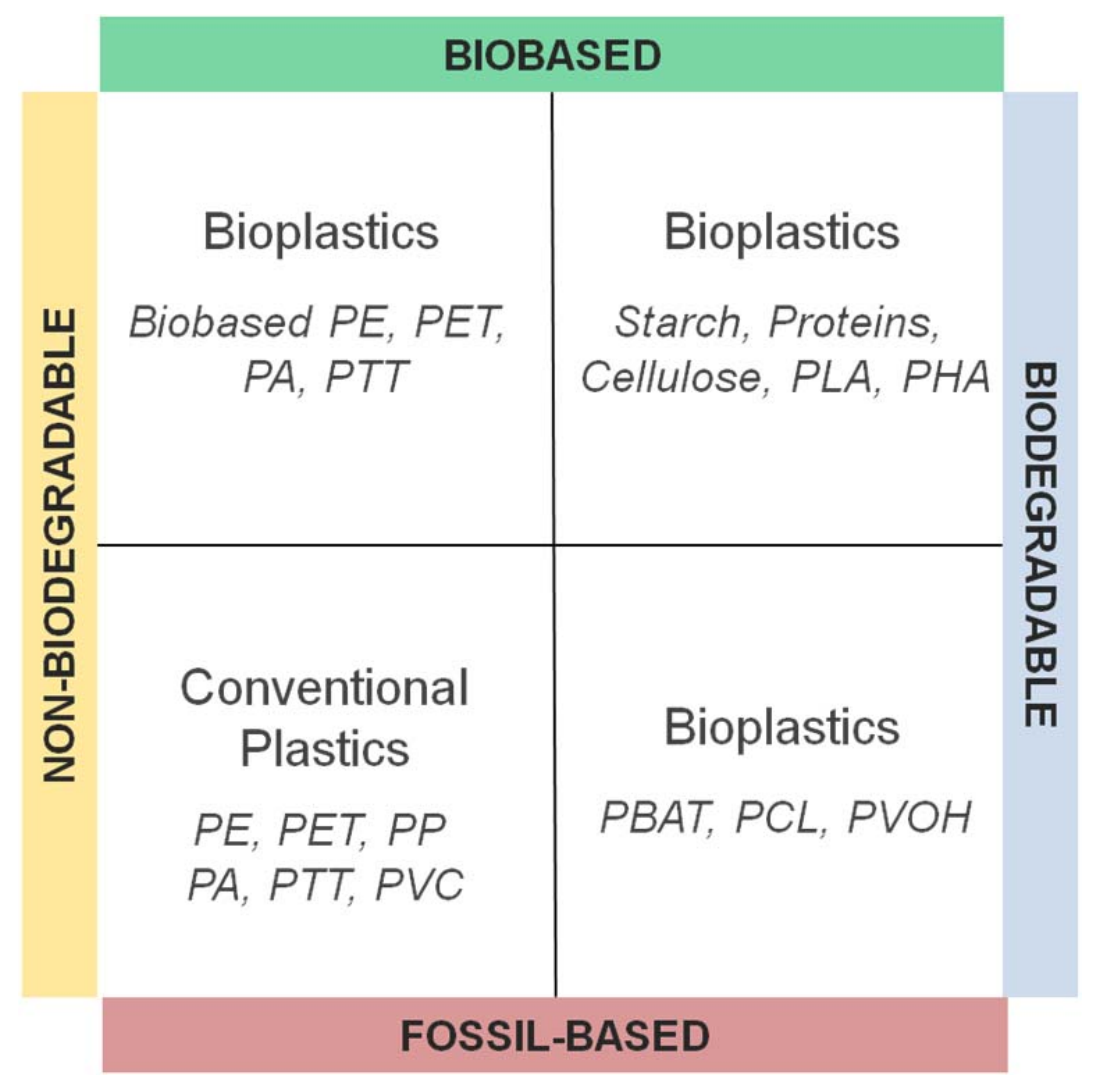

Figure I. 2. Classification of polymers according to their biodegradable-biobased nature. Source: European Bioplastics - Bioplastics, Materials. 


\section{a) Polymer obtained from biomass}

These are natural biopolymers, such as polysaccharides and proteins, directly extracted from biological and natural resources. They are characterized as being hydrophilic and somewhat crystalline in nature, making an excellent gas barrier (Dutta et al., 2006).

\section{- Polysaccharides}

Polysaccharides are long-chain polymers formed from mono- or disaccharide repeating units joined together by glycosidic bonds. As a consequence of their high - $\mathrm{OH}$ group content, polysaccharides are generally very hydrophilic and highly water-sensitive, leading to films with a poor water vapour barrier (Bourtoom, 2008). However, polysaccharides have good film-forming properties; their films present good mechanical and gas barrier properties, acting as efficient barriers against oil and lipids (Janjarassku and Krochta, 2010). In order to deal with their physicochemical drawbacks, polysaccharides can be chemically modified, cross-linked, hydrolysed or improved by using nanotechnology (De Moura et al., 2009).

\section{Starch and derivates}

Of all the natural polysaccharides available, starch is one of the most abundant, which is mainly obtained from corn, cereal grain, rice and potatoes. Likewise, it consists of a biopolymer derived from renewable resources, easily biodegradable, low cost and widely available (Jiménez et al., 2012a). Native starch granules are composed of both amylose and amylopectin, in different ratios depending on the origin and age of the starch (Cazón et al., 2016; Smith, 2001). For instance, corn and potato starch contain between 20 and $30 \%$ of amylose (Liu, 2005). Chemically, while amylose is a linear polymer composed of $\alpha-1,4$ anhydroglucose units, amylopectin is a highly branched polymer of short $\alpha-1,4$ chains linked by $\alpha-1,6$ glucosidic branching points (Cazón et al., 2016; Liu, 2005). Both amylose and amylopectin are structured by $\mathrm{H}$-bonding, leading to starch granules, which are made up of semicrystalline domains alternating with amorphous rings (Janjarassku and Krochta, 2010). The main crystalline component in granular starch is associated with the short-branching chains of the amylopectin; hence, the higher the content in amylopectin, the greater the crystallinity of the starch granules (Jiménez et al., 2012a). 
Although native starch granules are not soluble in cold water, due to the high number of intermolecular $\mathrm{H}$-bonds, they reach partial solubilisation when heated in water. In these conditions, the semi-crystalline nature and three-dimensional architecture of starch granules are gradually disrupted, leading to a phase transition from the ordered granular structure into a disordered state (Reddy et al., 2013; Xie et al., 2013), since water molecules interact with the hydroxyl groups of amylose and amylopectin (Hoover, 2001). When it takes place in an excess of water (>90\% wt/wt), this process is known as gelatinization and is irreversible and relevant when obtaining starch-based biodegradable films (Jiménez et al., 2012a). The addition of plasticizers during the heat treatment enables native starch to become thermoplastic (TPS, thermoplastic starch), acquiring similar properties to those of conventional plastics. In this sense, TPS-based films can be obtained by two main techniques, similarly to petroleum-based plastics: casting solution followed by drying (wet method), and thermoprocessing (dry method) (Zhang et al., 2014b). While the casting method is generally preferred as a means of obtaining edible preformed films or for the application of coatings by dipping, brushing or spraying onto food products, dry methods are more suitable for industrial-scale film manufacturing (Cazón et al., 2016). However, starch processing is much more complicated, due to the unsatisfactory processing properties resulting from its unique phase transitions, high viscosity, water evaporation and fast retrogradation. Nonetheless, many of these drawbacks can be dealt with by the proper development of the formulation and suitable processing conditions, namely plasticizer and lubricant addition, by using modified starch or copolymer and by blending it with more hydrophobic polymers/compounds or nanoclays (Liu et al., 2009).

As concerns the casting method, starch, plasticizer and the selected additives are firstly formulated into a water dispersion, which is heat treated to achieve starch gelatinization. The temperature of the treatment will depend on the starch source, taking into account that the heating temperature has a remarkable effect on TPS and starch degradation. Secondly, the suspension is cast into a well-levelled platform, cooled down and dried until a starch-based film can be peeled off (Zhang et al., 2014b). However, the casting method requires a high amount of solvent and is more applicable in labs than industry, where the dry method is preferred. A dry process can be used with those raw materials which have thermoplastic properties; meaning that they melt or become rubbery below decomposition temperature, acquiring the capability to be molded into a determined shape when submitted to a thermal/mechanical process. Nowadays, the main dry techniques employed are sheet/film extrusion, foaming extrusion, injection molding, compression molding, and reactive extrusion, using starch usually in combination with 
other polymers (Jiménez et al., 2012a). Extrusion, usually applied in a two-stage technique, is the most widely used technique for processing starch-based polymers, while compression-molding has been recently researched in depth for the processing of starch-based bioplastics (Liu et al., 2009). The great interest in biodegradable TPS that has been gained over the last few decades has increased the amount of research focusing on these techniques.

As commented on above, amylopectin is responsible for crystallinity in starch granules; however, when it comes to starch films, the higher the content in amylose, the higher the degree of crystallinity (García et al., 2000). The rearrangement of the linear molecules of amylose during the retrogradation process, occurring after gelatinization, leads to a more organized and crystallized structure for amylose regions, with respect to the amorphous formation gathered through amylopectin regions, which will be more sensitive to the effects of plasticizer addition. Hence, starch-based biodegradable films are transparent, odourless, tasteless and colourless; however, mainly because of their ability to form a continuous matrix, they are highly ordered due to the hydrogen-bonded network structure, in which crystalline and non-crystalline regions in the film are organized into alternating layers, leading to an excellent oxygen barrier. However, starch films present significant drawbacks that inhibit their use over synthetic polymers: mainly, their mechanical weaknesses (relatively high tensile strength (TS) but very low elongation capacity), and their highly hydrophilic nature, which makes starch films a poor barrier against water vapour (Cazón et al., 2016). In addition, the retrogradation process that takes place gives rise to a great variation in the mechanical properties over time (OrtegaToro et al., 2014). High-amylose starches have been reported to show better film-forming ability and mechanical properties (Liu et al., 2009); specifically, they have shown characteristics, such as greater strength and toughness (Van Soest et al., 1997), as well as a decrease in $T_{g}$ of TPS, leading to more ductile films (Byun and Kim, 2014). Moreover, starch films with a more crystalline structure are less sensitive to moisture and to the environmental relative humidity (Cazón et al., 2016). On the other hand, the presence of plasticizers in the matrix can lead to a decrease in the brittleness of starch films, leading to a decrease in strength, while increasing the elongation at break. However, plasticizers also improve molecular mobility throughout the polymeric network, leading to an increase in permeability to $\mathrm{O}_{2}$, water vapour and aroma compounds (Jiménez et al., 2012a). Different strategies have been used to deal with these drawbacks: 
- Incorporation of other components, such as carboxymethylcellulose (CMC), microcrystalline cellulose (MC), nanoclays, fibers, carbon nanotubes, surfactants, etc. (Byun and Kim, 2014; Ortega-Toro et al., 2014).

- Chemical modification through esterification, etherification and oxidation (Masina et al., 2016). More information about starch oxidation is detailed in section 1.3.1.

- Starch blends with other biopolymers or synthetic polymers, such as polyvinyl alcohol (PVA) (Bertuzzi et al., 2007), poly ( $\varepsilon$-caprolactone) (Newman et al., 2015), poly lactic acid (PLA) (Muller et al., 2016), chitosan (Mendes et al., 2016) or gelatin (Acosta et al., 2015). More information about starch blends with proteins is detailed in section 1.3.2.

Despite all of the disadvantages commented on above, starch remains the most promising of the polysaccharides available for food packaging, since, jointly with PLA, starch is the most widely used bioplastic material (Barnett, 2011). In this sense, different commercial bioplastics containing starch are nowadays available on the market. Ediflex $®$ is a flexible, good oxygen barrier, oil-resistant and heat-sealable bioplastic based on an extruded hydroxypropylated high-amylose starch film, which is effective at protecting meat products during frozen storage; MaterBi $\AA^{\circledR}$ is a starch-based material available in granular form that can be processed as thermoplastic material to form films or bags, which is commercialized by Novamont (Italy); Bio-P-TM®, commercialized by Bioenvelope (Japan); BIOPAR ${ }^{\circledR}$ is a material based on potato starch and is fully biodegradable, commercialized by BIOP Biopolymer Technologies AG, (Germany) (Jiménez et al., 2012a); LDPE-starch blends, commercialized under the trade name Ecostar $\AA$, Bioplast $\AA$ (from Biotec $\mathrm{GmbH}$ ) and NOVON ${ }^{\circledR}$ (from NOVON International); Biopur ${ }^{\circledR}$ (from Biotec $\mathrm{GmbH}$ ), Eco-Foam ${ }^{\circledR}$ (from National Starch \& Chemical) and Envirofill $\circledast$ (from Norel), which are obtained from transforming starch into a foamed material, capable of being pressed into trays (Siracusa et al., 2008); Starch-based materials applied in food packaging, such as milk chocolates packaged in corn starch trays, commercialized by Cadbury Schweppes food group (Marks \& Spencer), or cornbased packaging for organic tomatoes, commercialized by Iper supermarkets (Coop Italia, Italy) (Peelman et al., 2013). 


\section{Chitin and Chitosan}

Both polymers exhibit unique properties: they are renewable, biocompatible, biodegradable and non-toxic with excellent adsorption properties (Avérous, 2004). In particular, chitin is an abundantly available natural polysaccharide originating from the exoskeleton of invertebrates and chemically composed of repeating units of 1,4-linked 2deoxy-2acetoamido-a-D-glucose (Dutta et al., 2006; Reddy et al., 2013). When deacetylated to more than $50 \%$, it gives rise to chitosan (Kumar, 2000), which consists of a biodegradable cationic hydrocolloid with film-forming ability and with antimicrobial and antioxidant activity, both associated with its positive charge (Talón et al., 2016). Although chitosan is currently receiving more attention as a polysaccharide resource for biomedical applications (Francis and Matthew, 2000), extensive research aiming to develop biodegradable packaging for food preservation has been carried out, including its combination with other biopolymers, namely starch (Talón et al., 2016), gelatine (Ahmed and Ikram, 2016) or whey proteins (Jiang et al., 2016); it can also act as a vehicle of other antimicrobial compounds, such as essential oils (Perdones et al., 2012), cinnamaldehyde (Chen et al., 2016), or ethyl lauroyl arginate (LAE) (Rubilar et al., 2016).

\section{Cellulose}

Cellulose is a widely available, low cost material which is both renewable and biodegradable, mainly obtained from wood and cotton (Reddy et al., 2013). Chemically, cellulose is a polydisperse linear homogeneous polysaccharide originating from the repetition of $\beta$-1,4-D-glucopyranose units (Malmström and Carlmark, 2012). In its unmodified chemical structure, cellulose is highly crystalline, fibrous, and insoluble, with poor barrier and moisture resistance properties (Petersen et al., 1999). However, cellulose esters, such as cellulose acetate (CA), cellulose acetate butyrate $(C A B)$ and cellulose acetate propionate (CAP), are used in a broad variety of applications, including coating, biomedical and plastic applications (Amass et al., 1998). Other commercial water-soluble cellulose ethers, such as methyl cellulose (MC), hydroxypropyl cellulose (HPC), hydroxypropylmethyl cellulose (HPMC), and carboxymethyl cellulose (CMC), also show good film-forming properties (Janjarassku and Krochta, 2010). Bacterial cellulose, produced by Acetobacter xylinum, has lately been attracting interest, since it produces cellulose with good mechanical strength and biodegradability (Reddy et al., 2013). On the other hand, cellulose nanofillers are extensively used in the field of biodegradable packaging. Cellulose nanofibrils present both amorphous and crystalline regions. The 
isolation of a crystalline region, mainly by acid hydrolysis, gives rise to cellulose nanocrystals (Gardner et al., 2008), used as a reinforcement material due to their large specific surface area $\left(150 \mathrm{~m}^{2} \mathrm{~g}^{-1}\right)$, surface energy and their very high elastic modulus (about $150 \mathrm{GPa}$ ) (Cano et al., 2015).

\section{Other polysaccharides}

Pectin is a linear polysaccharide extracted from citrus peels and apple pomace by hot dilute mineral acid at $\mathrm{pH}$ 1.5-3.5. Chemically, it is composed of D-galacturonic acid units linked by $\alpha-1,4-$ glycosidic bonds (Farris et al., 2009). Commercially, it is possible to find pectin available with different degree of esterification (DE), high-methoxyl pectin (HMP, $D E>50)$, low-methoxyl pectin (LMP, DE $<50$ ), affecting solubility and gelation properties of pectin (Baldwin et al., 1995). Among their applications, pectin has been investigated as food to retard moisture loss and lipid migration, while improving handling and appearance of foods (Kester and Fennema 1986). More recently, Farris et al. (2009) described its suitability for obtaining hydrogels.

Alginates are salts of alginic acid, a copolymer consisting of D-mannuronic and Lguluronic acid monomers, which leads to films being obtained with a poor water resistance because they are hydrophilic in nature (Maizura et al., 2007). However, film strength and permeability can be altered by the concentration and rate of addition of polyvalent cations, the time of exposure, the $\mathrm{pH}$, the temperature and the presence of composite constituents (Janjarassku and Krochta, 2010).

\section{- $\quad$ Proteins}

Chemically constituted as random copolymers of different amino acids (Janjarassku and Krochta, 2010), proteins have been traditionally used in adhesives and as edible films or coatings (Petersen et al., 1999), being highly suitable for biodegradable packaging applications, due to their excellent gas barrier properties, good mechanical and optical properties and the fact that they are thermoplastically processable (Dutta et al., 2006; Janjarassku and Krochta, 2010). However, because of their high sensitivity to water,much research has been focused on improving their properties by physical, chemical or enzymatic treatments (Wihodo and Moraru, 2013). 


\section{Milk Proteins}

Mainly divided into two classes, Caseins (80 \%) and Whey Proteins (20\%), they are broadly used to obtain edible films. Caseins show a very low cysteine content, which enables them to obtain water-insoluble films by heat denaturation (Chen, 2002). However, the highly stretchable melts obtained from casein make them suitable for film blowing (Dutta et al., 2006); in addition, their films act as an excellent barrier against $\mathrm{O}_{2}$, and they have great potential to be used as carriers of flavours, nutrients, or bioactive ingredients (McHugh et al. 1994). As regards whey proteins, available as concentrates (WPC) or isolates (WPI), they are able to form water-insoluble films by means of heat denaturation, promoting intermolecular disulfide bonding and hydrophobic interactions (McHugh and Krochta, 1994); in addition, water-soluble edible films originate from the cohesion of WPI through $\mathrm{H}$ bonding between native globular molecules (Pérez-Gago et al., 1999). Their films and coatings have been used to prevent rancidity due to their excellent barrier properties against $\mathrm{O}_{2}$. Besides, research has focused on their ability as carriers and the controlled release of antimicrobial compounds (Janjarassku and Krochta, 2010).

\section{Wheat Gluten}

Mainly composed of gliadin and glutenin fractions, gluten is a globular protein with filmforming ability through the combination of hydrophobic interactions and hydrogen, ionic, and disulphide bonds (Janjarassku and Krochta, 2010). Gluten is easily available on the market at low cost and its films exhibit good viscoelastic properties, an ability to crosslink upon heating and low water solubility, which all make gluten an interesting biopolymer for packaging (Zubeldía et al., 2015). Other compounds, such as lipids (Rocca-Smith et al., 2016) or essential oils (Ansorena et al., 2016) have been incorporated with gluten in its application. Research into gliadin-based films is also available (Balaguer et al., 2015; Hernández-Muñoz et al., 2004; Hong et al., 2016; Soares and Soldi, 2010).

\section{Collagen and gelatin}

Collagen is a fibrous insoluble protein, widely found in nature as the major constituent of skin, bones and connective tissue (Park et al., 2008). Traditionally, it has been used for 
preparing edible sausage casing, being one of the most commercially successful edible protein films (Dutta et al., 2006; Janjarassku and Krochta, 2010). On the other hand, gelatin consists of a water soluble protein with a high content of glycine, proline and hydroxyproline amino acids, which is obtained by means of collagen controlled hydrolysis (Park et al., 2008). Gelatin has the ability to form thermo reversible gels on cooling, after its dissolution at $40^{\circ} \mathrm{C}$. The drying of the gel, gives rise to films obtained by cross-linking between amino and carboxyl components of amino acid residue side groups. The obtained films, with the addition of a plasticizer, have sufficient stability, strength and flexibility to allow them to be used as support and packaging material (Janjarassku and Krochta, 2010; Park et al., 2008). Moreover, gelatin coatings can reduce $\mathrm{O}_{2}$, moisture and oil migration, while acting as carriers of bioactive compounds (Krochta and De Mulder-Johnston, 1997). Gelatin films have been commonly applied in both food and pharmaceutical practice (De Reynal and Multon, 2009); nonetheless, its effectiveness as biodegradable packaging material is supported by a wide number of studies. More recently, active agents, such as ginger essential oil (Alexandre et al., 2016), lysozyme (Dekina et al., 2016) or silver-cooper nanoparticles (Arfat et al., 2017) has been incorporated into gelatin. Mohajer et al. (2017) successfully obtained fish gelatin films blended with agar, improving the thermal behaviour of gelatin. Sahraee et al. (2017) incorporated corn oil and chitin nano fibers (N-chitin), improving the physical and antifungal properties of gelatin films. Other authors also studied the properties of gelatin-chitosan blends (Kim et al., 2005; Pereda et al., 2011). Likewise, a combination of gelatin with starch has been thoroughly studied. In this sense, more studies into starch-gelatin blends are discussed in section1.3.b.

\section{Other proteins}

Soy protein and Corn Zein are proteins of plant origin that are of interest in the obtaining of films. Specifically, Soy Protein Isolate (SPI) generates films by the heat denaturation of casting solutions (Kunte et al., 1997; Monedero et al., 2009, 2010). These films can be applied on pre-cooked meat products to control lipid oxidation and limit surface moisture loss (Wu et al., 2000), as well as on the scoating of fruits, vegetables, and cheese (Petersen et al., 1999). As regards Corn Zein, it comprises a group of alcohol soluble proteins (prolamines) found in corn endosperm, insoluble in water, except at very low or high $\mathrm{pH}$, and insoluble in anhydrous alcohols (Gennadios \& Weller, 1990). Corn Zein films are brittle and need plasticizers to make them flexible. Corn zein has been used in formulations of specialty food and pharmaceutical coatings (Dutta et al., 2006). 


\section{b) Synthetic biodegradable polymers}

Of the polymers produced by chemical synthesis using renewable biobased monomers, polylactic acid (PLA) is the main biopolymer (Dutta et al., 2006).

PLA is a family of biodegradable aliphatic thermoplastic polyesters derived from the controlled polymerisation of lactic acid and obtained from $100 \%$ renewable plant sources, such as corn starch or sugar. PLA is a biocompatible material which has been approved by the US Food and Drug Administration for direct contact with biological fluids. It can be processed by extrusion, injection moulding, film casting or fibre spinning, giving rise to transparent films with great mechanical strength (Muller et al., 2016). However, PLA films are very brittle with very low elongation at break, although a great deal of research is being carried out with the aim of improving their flexibility, mainly by blending with plasticizer (Rasal and Hirt, 2009). On this basis, PLA is nowadays one of the most promising polymers for commercial use as a substitute for low-density polyethylene (LDPE), high-density polyethylene (HDPE), polystyrene (PS) and polyethyleneterephthalate (PET) (Peelman et al., 2013).

Poly( caprolactone) (PCL) is another aliphatic polyester obtained by chemical synthesis from crude oil or from renewable resources, such as polysaccharides. It is a thermoplastic, biodegradable, biocompatible and semi-crystalline polymer that has a low glass transition temperature $\left(\sim-60^{\circ} \mathrm{C}\right)$ and melting point $\left(58-60^{\circ} \mathrm{C}\right)$ (Cao and Huneault., 2008). PCL-based films have good water resistance and are easily processable (Flieger et al., 2003), exhibiting low water vapor permeability but relatively high oxygen permeability (Ortega-Toro et al., 2016).

\section{c) Biopolymers produced by microbial fermentation}

Apart from bacterial cellulose, the olyhydroxialkanoates' (PHA) family, of which polydroxybutirate (PHB) is the most common, are the main biodegradable polymers derived from microbial fermentation. More specifically, these polymers are produced in the microbial cells through a fermentation process and then harvested by using solvents, such as chloroform, methylene chloride or propylene chloride (Peelman et al., 2013). PHB shows good processability, yielding materials with a high degree of transparency and stiffness, since it presents physical properties (melting points, degrees of crystallinity and glass transition temperatures) that are very similar to polypropylene (Requena et al., 2016b). However, its high degree of crystallinity makes it stiffer and more brittle than PP. 
In order to minimize these drawbacks, the copolymer polyhydroxybutyrate-valerate (PHBV), less stiff and tougher, has been developed (Siracusa et al., 2008).

\subsection{Strategies for improving properties of starch films used in the present study.}

Different actions aimed at enhancing starch hydrophobicity in order to reduce its water sensitivity and compatibility with other biopolymers, such as proteins, have been used (Azeredo and Waldron, 2016). In this study, starch oxidation and blending with different proteins have been analyzed. Proteins can improve the properties of starch films, as reported by different authors (Acosta et al., 2015; Al-Hassan and Norziah, 2012; Fakhoury et al., 2012, 2013), as well as impart active properties in line with their antioxidant or antimicrobial properties, as discussed below.

\subsubsection{Starch oxidation}

The chemical modification of native starch introduces remarkable changes in terms of gelatinization, swelling, solubility properties, pasting and the retrogradation characteristics of starch (Tharanathan, 2005). Consequently, modified starches can acquire more adequate physicochemical or biodegradable properties. Of all the native starch modification possibilities available, oxidized starches have been reported to show a significant modification in their molecular structure, enhancing the controlled release of active agents entrapped in the starch materials (Masina et al., 2016). Oxidation process of starch is commonly headed for the three available hydroxyl groups which can be substituted through oxidative or substitutive mechanisms, which typically involve a series of reactions, occurring at a suitable temperature and $\mathrm{pH}$ value (Balakrishnan and Jayakrishnan, 2005; Li et al., 2011). Firstly, the oxidation of hydroxyl groups to carbonyl or carboxyl groups takes place, followed by the depolarisation of chains by cleaving the $\alpha-(1-4)$ links between the glucopyronose units (Zhang et al., 2011; Zhang et al., 2012). Subsequent to the reaction, dyaldehyde starch (DAS) is obtained, which has the ability to act as a crosslinking agent while increasing the hydrophobic nature of the polymer, due to the reduction in hydroxyl groups and the formation of carboxyl and carbonyl groups.

Starch oxidation can be performed by employing different oxidizing reagents, the most frequently used being: permanganate, nitrogen dioxide, sodium hypochlorite, sodium 
periodate and chromic acid (Balakrishnan \& Jayakrishnan, 2005). Nowadays, hypochlorite oxidation is the most common method for the production of oxidized starches on an industrial scale (Zhang et al., 2012). However, periodate oxidation is being widely researched as an oxidizing agent in the laboratory (Fiedorowicz and Para, 2006; Kamoun, 2015; Zhang et al., 2014a; Para and Konieczna-Molenda, 2010; Wang et al., 2015; Yu et al., 2010). In particular, the periodate oxidation of starch is a selective reaction in which periodate ions yield the cleavage of the $\mathrm{C} 2-\mathrm{C} 3$ bond of the anhydroglucose units of the starch polysaccharide chain, forming the dialdehyde groups (Fiedorowicz and Para, 2006) (Figure I.3).
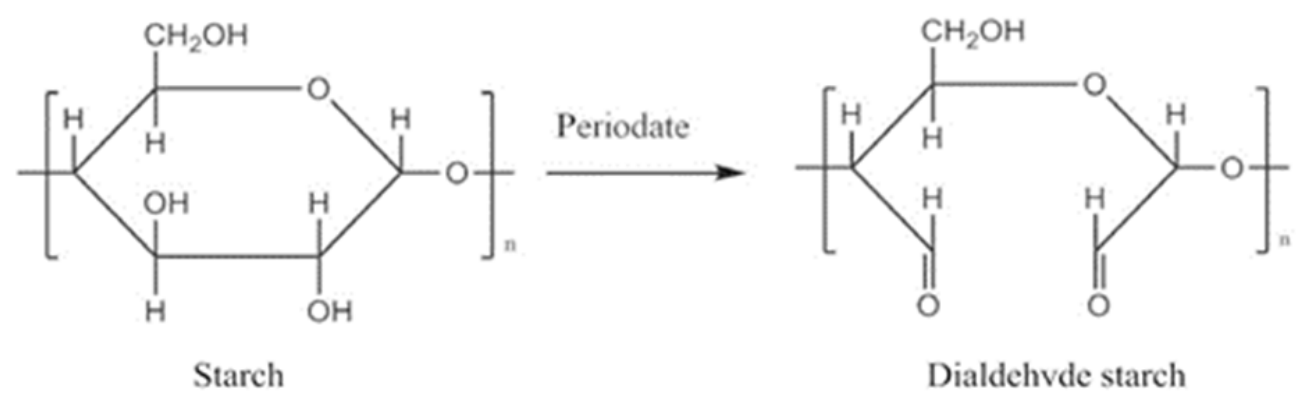

Dialdehvde starch

Figure I.3. Periodate oxidation of starch.

As a consequence of the oxidation process, the polysaccharide chains in native starch undergo fragmentation, resulting in changes in the physicochemical properties, such as thermal and crystalline properties (Zhang et al., 2014a). In fact, the oxidation of starch greatly affects the thermostability of the polymer, decreasing the temperature of both onset and maximum degradation rate (Soliman et al., 1997; Zhang et al., 2012). Moreover, as a result of the changes occurring in its chemical structure, DAS also shows a great crosslinking ability (Figure 1.4). In this sense, it is currently being targeted in biomedical studies, mainly due to its suitability as a drug delivery carrier (Yu et al., 2007), and in enzyme immobilization applications (Masina et al., 2016). Oxidized starch derivatives are able to form hemiceacetyls/acetyls crosslinked derivatives, leading to reinforced systems with controllable swellability, such as bioplastics and hydrogels (Singh et al., 2007). In addition, DAS has a great potential to act as a crosslinking agent with proteins, due to the condensation reaction between carbonyl and amino groups (Wang et al., 2015). On the other hand, Song et al. (2010) also pointed out the antimicrobial activity of the DAS aqueous suspension, which makes it a potential material for antibacterial applications. In this sense, the potential applications of DAS has garnered it a great deal of attention from the food industry, especially as a component of 
biodegradable plastics for packaging purposes, as well as for its very low toxicity when compared with traditional crosslinking agents, such as glutaraldehyde (Zhang et al., 2014a).

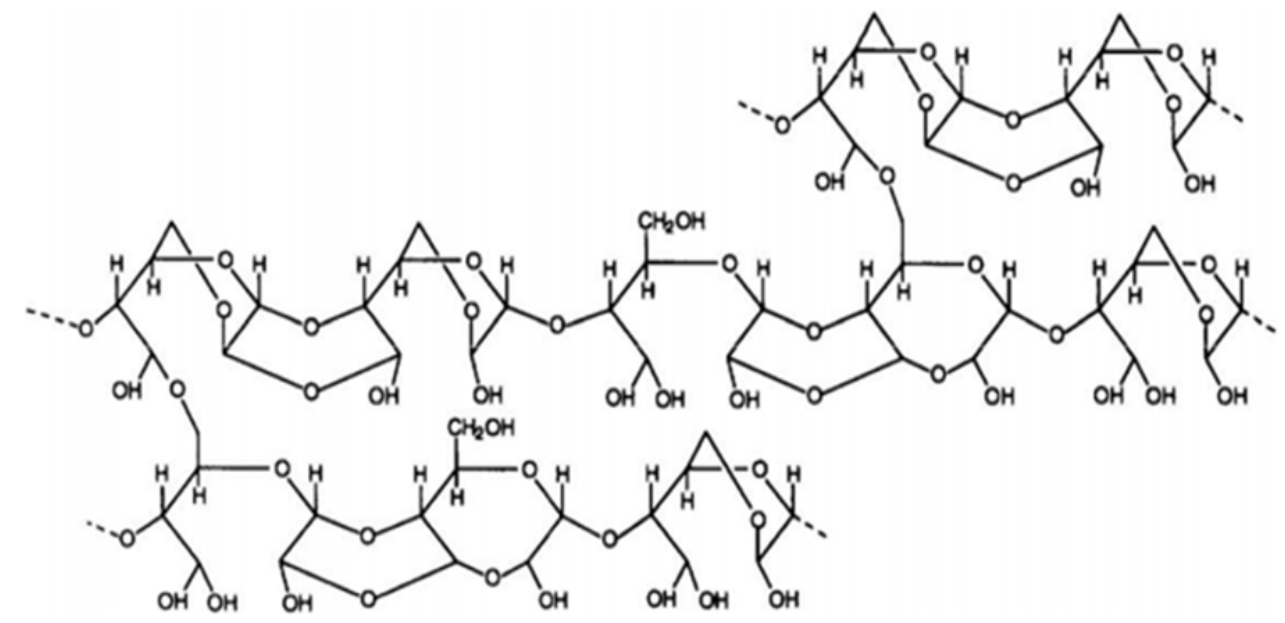

Figure I. 4. Internal crosslinking of DAS by formation of acetal bonds between carbonyl and hydroxyl groups (Du et al., 2008).

\subsubsection{Starch-protein blend films}

In order to modulate/enhance the properties of starch films, its blending with proteins has been extensively studied. Jagannath et al. (2003) reported that, although protein and starch films separately are highly permeable to water vapour, a completely miscible, blended or compatible film may decrease its permeability. Interaction between both polymers can be produced by non-covalent attractive forces, namely electrostatic forces, hydrogen bonding, hydrophobic or van der Waals interactions, and covalent bonding, which is determined by a wide variety of functional groups (ionic, polar, non-polar), greatly influenced by the polymer conformation (globule, random coil, rigid rod, helix, etc.) and the molecular weight of both starch and protein (Semenova et al., 2016). Crosslinking mechanisms are especially useful for biopolymer materials, since the reduction in the mobility in the inner network enhances their mechanical, barrier and thermal properties as well as their water resistance. DAS has been reported to form crosslinks with $\varepsilon$-amino groups of protein side chains by $\mathrm{C}=\mathrm{N}$ linkages (Schiff's base formation) (Azeredo and Waldron, 2016). In this sense, DAS-protein blends may be a great approach in the area of biodegradable packaging applications for food. 
Of the possible starch-protein blends used to form films, starch-gelatin (S-G) blends have been studied by different authors as shown in Table I. 1.

Table I. 1. Recent studies in starch - gelatin (S-G) blend films.

\begin{tabular}{|c|c|c|c|c|}
\hline Starch source & $\begin{array}{l}\text { Gelatin } \\
\text { source }\end{array}$ & $\begin{array}{l}\text { Starch:Gelatin } \\
\text { ratios }\end{array}$ & $\begin{array}{l}\text { Method for obtaining } \\
\text { film }\end{array}$ & Reference \\
\hline Cassava starch & $\begin{array}{l}\text { Bovine gelatin } \\
\text { type A }\end{array}$ & $1: 0,1: 1,3: 1,0: 1$ & Casting & $\begin{array}{c}\text { Acosta et al., } \\
2015\end{array}$ \\
\hline Sago starch & Fish gelatin & $1: 0,2: 1,3: 1,4: 1,5: 1$ & Casting & $\begin{array}{l}\text { Al-Hassan and } \\
\text { Norziah, } 2012\end{array}$ \\
\hline $\begin{array}{l}\text { Native, acetylated } \\
\text { and crosslinked } \\
\text { Manioc starch }\end{array}$ & $\begin{array}{l}\text { Bovine gelatin } \\
\text { type A }\end{array}$ & $4: 1,1: 1,1: 4$ & Casting & $\begin{array}{l}\text { Fakhoury et } \\
\text { al., } 2012\end{array}$ \\
\hline $\begin{array}{l}\text { Lipophilic Corn } \\
\text { starch }\end{array}$ & $\begin{array}{l}\text { Bovine gelatin } \\
\text { type A }\end{array}$ & $4: 1,1: 1,1: 4$ & $\begin{array}{l}\text { Casting, press- } \\
\text { blowing, extrusion- } \\
\text { blowing }\end{array}$ & $\begin{array}{l}\text { Fakhoury et } \\
\text { al., } 2013\end{array}$ \\
\hline $\begin{array}{l}\text { Native, waxy and } \\
\text { modified, Corn } \\
\text { starch }\end{array}$ & $\begin{array}{l}\text { Bovine gelatin } \\
\text { type A }\end{array}$ & $4: 1,1: 1,1: 4$ & Casting & $\begin{array}{l}\text { Fakhoury et } \\
\text { al., } 2015\end{array}$ \\
\hline DAS & $\begin{array}{l}\text { Bovine gelatin } \\
\text { type B }\end{array}$ & $0: 1,1: 20,1: 10,3: 10$ & Compression molding & $\begin{array}{c}\text { Martucci et al., } \\
2009\end{array}$ \\
\hline Potato starch & $\begin{array}{l}\text { Food grade } \\
\text { gelatin }\end{array}$ & $\begin{array}{c}0: 1,1: 10,1: 5,3: 10 \\
4: 10,1: 2\end{array}$ & Casting & $\begin{array}{l}\text { Podshivalov et } \\
\text { al., } 2016\end{array}$ \\
\hline $\begin{array}{l}\text { Modified water- } \\
\text { soluble Potato and } \\
\text { Corn starches }\end{array}$ & $\begin{array}{l}\text { Food grade } \\
\text { gelatin Gelatin }\end{array}$ & $\begin{array}{c}0: 1,1: 1,6: 4,7: 3,4: 1 \\
9: 1,1: 0\end{array}$ & Casting & $\begin{array}{l}\text { Soliman and } \\
\text { Furuta, } 2014\end{array}$ \\
\hline $\begin{array}{l}\text { High amilyose } \\
\text { Corn starch }\end{array}$ & $\begin{array}{l}\text { Bovine gelatin } \\
\text { type A }\end{array}$ & $1: 10,1.2$ & Casting & $\begin{array}{l}\text { Wang et al., } \\
2017\end{array}$ \\
\hline $\begin{array}{l}\text { Hydroxypropylated } \\
\text { high amylose Corn } \\
\text { starch }\end{array}$ & $\begin{array}{l}\text { Food grade } \\
\text { gelatin Gelatin }\end{array}$ & $\begin{array}{c}1: 0,4: 1,6: 4,4: 6,1: 4 \\
0: 1\end{array}$ & Casting & $\begin{array}{c}\text { Zhang et al., } \\
2013\end{array}$ \\
\hline
\end{tabular}

The variation in the films' properties was dependent on the proportion of both polymers. Generally, on the basis of the mechanical and barrier properties, an equal proportion of both polymers in the film resulted in the best S-G blend (Acosta et al., 2015, Fakhoury et al., 2013). In comparison with pure starch films, S-G films show a great improvement in the tensile behaviour, leading to harder films with a greater resistance to break and greater extensibility (Acosta et al., 2015; Al-Hassan and Norziah, 2012; Fakhoury et al., 2013, 2015). Acosta et al. (2015) also observed an increase in the stiffness and resistance to break after 5 storage weeks in controlled conditions, which may be caused by the enhancement of the polymers' interaction over time. Wang et al. (2017) observed a decrease in the solubility as well as a higher degree of thermal stability for S-G films when compared to pure $G$ films. On the other hand, a remarkable influence of the filmobtaining methodology and the chemical composition of starch has been evidenced. Casting procedure yields films with lower WVP values and greater resistance to break, in comparison with those obtained by thermoprocessing (Fackhoury et al., 2013). More 
specifically, compression moulded films exhibited a greater ability for mass transport processes than cast films, since they might show multiphasic structures with weak interphase adhesion, resulting in a structure that is not as tight as in cast films, where polymers' interactions are promoted in the water solution before the drying step (Fackhoury et al., 2013). As regards the chemical composition of starch, Soliman and Furuta (2014) observed a better miscibility with $G$ in the case of those films based on high amylose content starch, which gave rise to an enhancement of both barrier and mechanical properties, depending on the S-G ratio. The presence of a higher proportion of linear chains than branched molecules may lead to a better interaction of starch and gelatin chains.

Other authors have focused their studies on the development of starch films incorporating other proteins, such as soy protein (Chinma et al., 2012; Galus et al., 2013; Rhim et al., 1998), whey protein (Azevedo et al., 2016, Basiak et al., 2015), zein (Gao et al., 2016; Parris et al., 1997; Spence et al., 1995), peanut protein (Li et al., 2015; Sun et al., 2013) or caseinate (Arvanitoyannis and Biliaderis, 1997; Jiménez et al., 2012b). As reported for S-G blends, the incorporation of protein into starch edible films improved the functionality and applicability of the films by enhancing their mechanical, thermal and barrier properties (Azevedo et al., 2016; Chima et al., 2012; Gao et al., 2016; Li et al., 2015; Sun et al., 2013). Jiménez et al. (2012b) also observed a reduction in the crystallinity of the starch films when blended with sodium caseinate, as well as an inhibition of recrystallization during the films' storage.

Special attention is required for DAS-protein films due to the covalent interactions promoted by carbonyl-amino reactions. The introduction of DAS into protein films has given rise to films with better functionality (Martucci and Ruseckaite, 2009; Rhim et al., 1998). Spencer et al. (1995) also noticed an increase in water resistance after DAS incorporation. However, crosslinking with the protein network could imply a reduction in the biodegradability of the films (Martucci and Ruseckaite, 2009). Moreover, the reaction that takes place between carbonyl and amino groups leads to the formation of Maillard compounds, resulting in film browning, which can be undesirable for some food packaging materials. The thermoprocessing of these films implies the application of high temperatures, which could extend the interaction between both DAS and proteins, increasing film browning. In addition, the formation of carbonyl groups decreases the thermal stability of DAS (Soliman et al., 1997; Zhang et al., 2007), limiting its application in thermoprocessing methods. 


\subsection{Active biodegradable films for food packaging}

Nowadays, consumer concerns about health-related issues has given rise to a growing interest in developing active packaging for food preservation, based on the addition of natural compounds to the biodegradable matrices (Irkin and Esmer, 2015). Food spoilage can be produced by several factors, leading to changes in the food that can affect human health after food consumption. In this sense, microbial growth is the most common cause of spoilage (Ibarra et al., 2016). Consequently, active packaging is focused on fighting not only spoilage microorganisms, whose metabolic end products or enzymes cause off-odours, off-flavours, texture problems, and discoloration of food; but also pathogenic microorganisms, both infective agents and toxin producers (Davidson and Taylor, 2007). In addition, oxidative processes occurring during the processing and storage of food products also greatly affect both the sensory and nutritional properties of food. Specifically, lipid oxidation is responsible for rancid odours and flavours, a decrease in nutritional quality and the formation of potentially toxic compounds (Atarés et al., 2016).

On the basis of this scenario, a wide number of studies are available that focus on the development of active biodegradable packaging by means of the addition of antimicrobial and/or antioxidant compounds with no negative effects on human health, (Atarés and Chiralt, 2016; Ibarra et al., 2016; Irkin and Esmer, 2015; Raybaudi-Massilia et al., 2016; Sánchez-González et al., 2015). As defined by Quintavalla and Vicini (2002), an active packaging is "a type of packaging that changes the condition of the packaging to extend shelf-life or improve safety or sensory properties while maintaining the quality of the food". Many active compounds have been effectively applied during the last few decades to obtain biodegradable active films: essential oils, plant volatiles and extracts, bacteriocins, organic acids, metallic nanoparticles, peptides, enzymes or chelating agents. Hence, starch/protein blends have been proven to act as good carriers for a broad variety of active compounds, exhibiting antioxidant and antimicrobial capacity (Acosta et al., 2016; Jagannath et al., 2006; Jiménez et al., 2014; De Oliveira Pizzoli et al., 2016). Antimicrobial films can be classified as migrating and non-migrating systems. The former include volatile antimicrobials that release to the head space, acting on the surface microorganisms. In non-migrating systems, covalent immobilization of actives, such as antimicrobial polymers or enzymes in polymer matrices, limits their release to the food and their action occurs through their direct contact with the potentially contaminated surface or by adsorption of the electrostatically charged microbial cells. Materials with activated surfaces (for instance with amino groups) by using different 
chemical or physical methods have been also studied as antimicrobial materials. The mode of action of active films is summarized in Figure I. 5 (Ibarra et al., 2016).

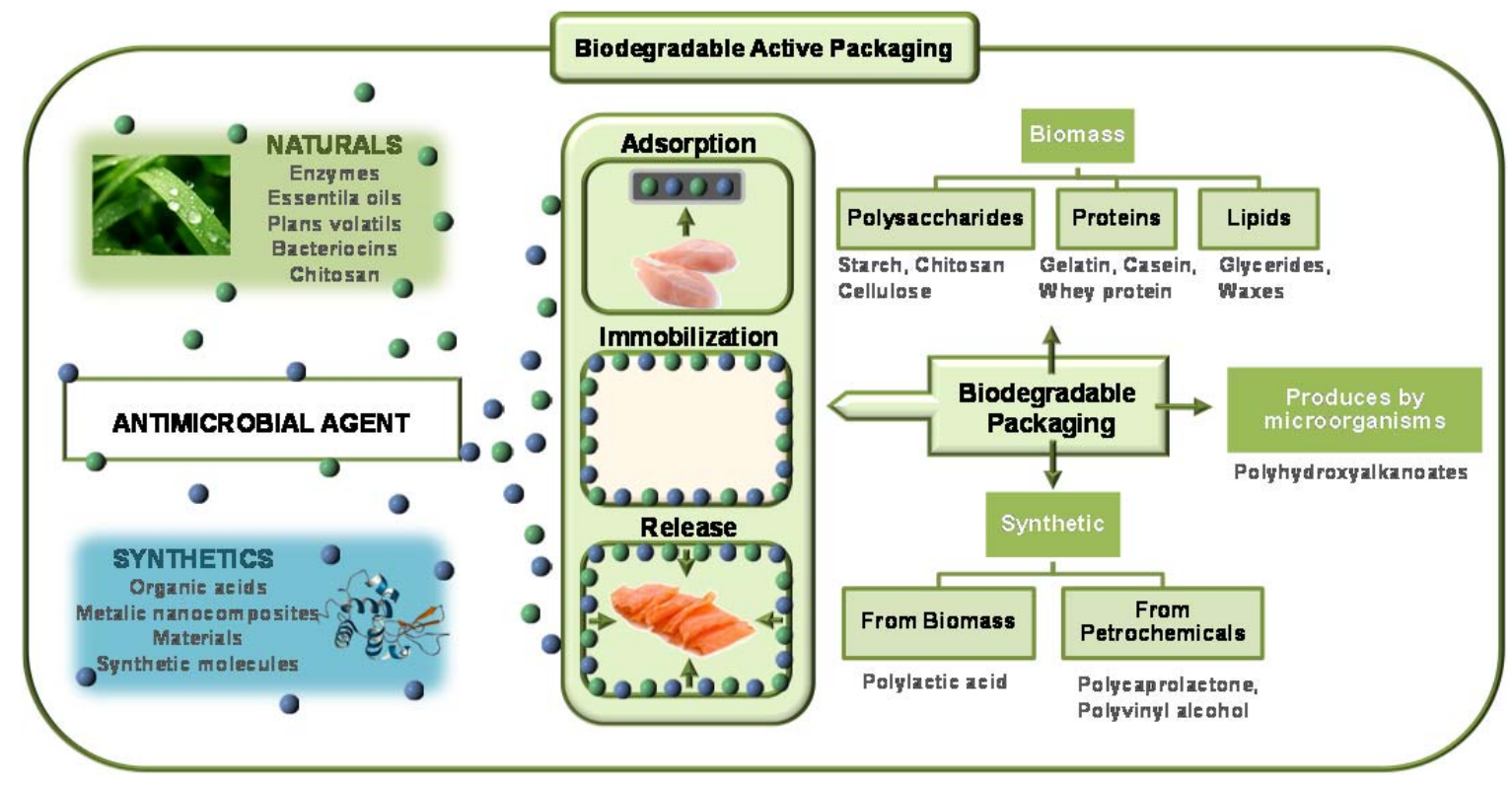

Figure I. 5. Scheme of a biodegradable active packaging system, comprised of biodegradable polymers and active agents incorporated into the packaging material through absorption, release, or immobilization systems (adapted from Ibarra et al. 2016).

Table I. 2 summarizes some of the most recent studies into active biodegradable films. The use of essential oils (EOs) for the development of active biodegradable films has been exhaustively studied during the last few years. Recognized as safe by the US Food and Drug Administration, EOs are oily, aromatic and volatile liquids of complex composition with two or three major components (Requena et al., 2016a). Despite their great effectiveness as both antioxidant and antimicrobial agents, their volatile nature leads to great losses during the process of obtaining the film, resulting in a decrease in the effectiveness and the need to use large initial amounts (Jiménez et al., 2014). In this sense, Atarés and Chiralt (2016) report an extensive revision on the use of essential oils as active compounds in biodegradable materials for food packaging, summarizing the antimicrobial activity of a great number of EOs in different matrices. They pointed out that the EO losses are minimized by their encapsulation into nanometric surfactant micelles. Jiménez et al. (2014) incorporated lemon EO into nanoliposomes in starchsodium caseinate based films, but no antimicrobial activity against Listeria monocytogenes was noticed, probably due to the low antilisterial activity of the EOs or as a result of the lack of effective release of active due to the encapsulation. However, Acosta et al. (2016) obtained effective antifungal activity against Fusarium oxysporum f.sp. gladiolo and Colletotrichum gloesporoides by incroporating cinnamon bark, clove 
and oregano EOs into starch-gelatin blend films, although only $35-45 \%$ of the initial essential oil was retained in the film matrix. On the other hand, Kechichian et al. (2010) applied cinnamon and clove powder into starch films for the preservation of bread slices. Nevertheless, the viable yeast and mould counts at the end of the storage of bread slices in contact with the films were similar or higher than in the respective control.

Other natural compounds with antioxidant properties have been incorporated into biodegradable films. Marcos et al. (2014) obtained antioxidant films based on polystyrenes with the incorporation of $\alpha$-tocopherol and olive leaf extract. Ciannamea et al. (2016) observed a higher antioxidant activity of soy protein films with incorporated red grape extract when films were obtained by compression moulding instead of casting method; this is probably due to a weaker retention of the active in the thermoprocessed matrix, since protein-polyphenol interactions occur to a greater extent in cast films, inhibiting the release of the active. This indicates the great influence of the method employed to obtain the films on the release properties of the matrix and, thus, the film activity. However, Jagannath et al. (2006) tested the antimicrobial activity of neem extract incorporated into starch-gelatin blend based films, observing a decrease in their in vitro effectiveness against E.coli, Staphylococcus aureus, Bacillus cereus, Salmonella typhimorium, Pseudomonas sp. when films were heat-processed, which could be related with the losses of active agents as a result of the thermal treatment.

The incorporation of metallic nanoparticles into biodegradable packaging for the purposes of enhancing the mechanical and barrier properties and extending food shelf life has also been extensively studied by different authors. Recently, Cano et al. (2015) and De Oliveira Pizzoli et al. (2016) incorporated silver nanoparticles, which show strong inhibitory or bactericidal effects for a broad spectrum of bacteria, fungi, and viruses, into starch/PVA and PLA/TPS/Gelatin blend films, respectively. The antimicrobial activity of silver nanoparticles was successfully proven, finding the effectiveness to be dependent on the release behaviour of silver from the films in contact with the food medium (Cano et al., 2015). 
Table I. 2. Some examples of antimicrobial/ antioxidant biodegradable films obtained by the incorporation of different active compounds.

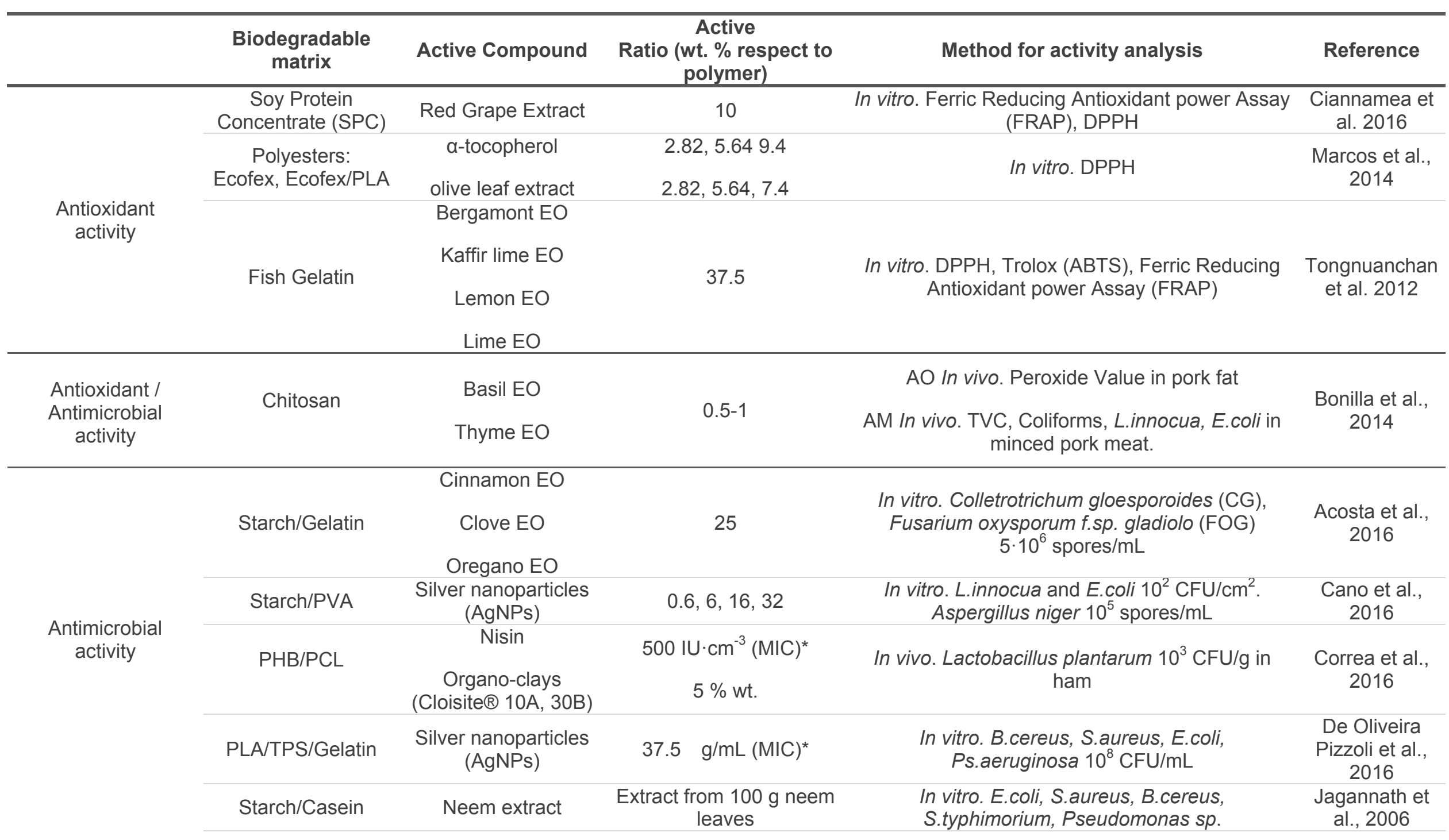




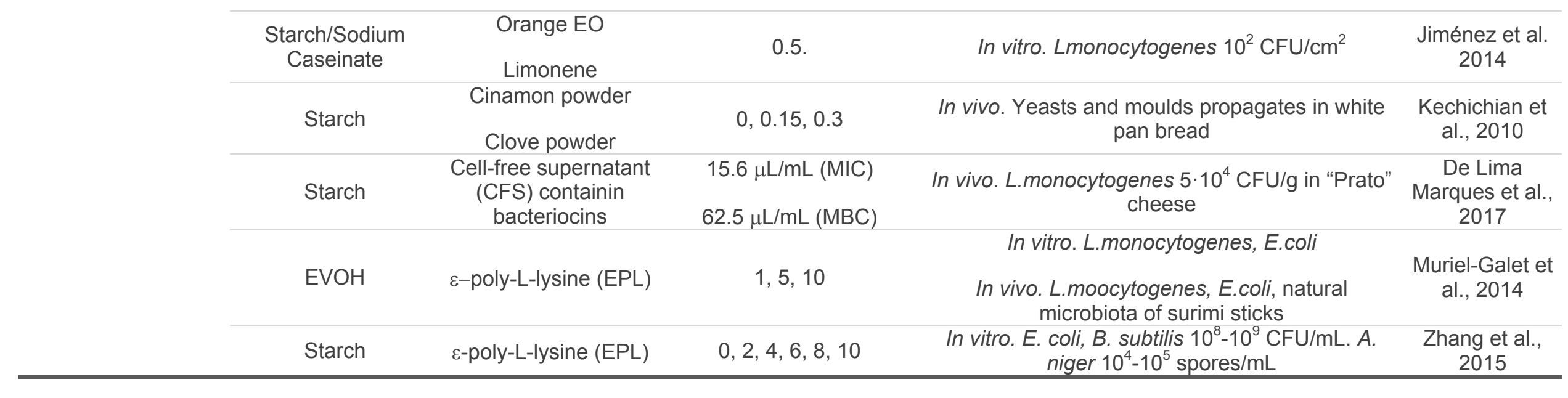

*activated surface by introducing the film into a stock with the indicated concentration. 
Other biologically-derived active compounds which have increasingly been the subject of much interest in recent years, especially due to their antilisterial activity, are bacteriocins, which consist of peptidic antimicrobial metabolites, originating from different bacteria, with bactericidal activity against other generally related species (Irkin and Esmer, 2015). Bacteriocins are thermo-stable, odourless, colourless and tasteless, nisin being the only commercial bacteriocin approved for food applications (Elsser-Gravesen and ElsserGravesen, 2013). Correa et al. (2017) successfully incorporated nisin into PHB/PCL blend based films containing oregano-clays, and proved them to be effective against Lactobacillus plantarum inoculated in ham slices. However, De Lima Marques et al. (2017) pointed out the loss of activity of purified bacteriocins when incorporated directly into food, the application of cell-free supernatant (CFS) containing bacteriocins being an interesting alternative, due to the incorporation of biologically active metabolites that cause synergistic effects on the products. The starch films obtained with these CFS were effective at controlling Listeria monocytogenes Scott A in slices of "Prato" cheese, maintaining the activity for 30 days.

In line with the use of peptidic antimicrobial agents, $\varepsilon$-poly-L-lysine (EPL) is also a biologically-derived active compound of interest for food preservation purposes due to its high degree of antimicrobial activity and established safety. Chemically, EPL is a homopoly amino acid characterized by a peptide bond between the $\alpha$-carboxyl and the $\varepsilon$ amino groups, which is industrially produced by the aerobic fermentation of Streptomyces albulus (Shih et al., 2006). Muriel-Galet et al. (2014) incorporated EPL into $\mathrm{EVOH}$ films and observed a strong antimicrobial effectiveness on both Listeria monocytogenes and Eschericha coli, in in vitro studies and in inoculated surimi sticks stored under refrigeration, showing a lower degree of inhibition in Escherichia coli. Likewise, Zhang et al. (2015) also observed a greater inhibition of the Gram positive bacteria Bacillus subtilis than Gram negative Escherichia coli, for EPL, although in both cases, the effectiveness was higher than against the fungi Aspergillus niger.

The incorporation of peptidic active compounds into starch or starch/protein blend matrices could be an interesting approach, since the interaction between the hydroxyl groups of starch and the amino groups of the peptidic compounds can be expected, leading to an enhancement in the mechanical properties of the films while improving the compatibility between polymers. In this sense, the molecular weight of the compounds may interfere with the integration into the polymer matrix, as well as with the diffusion toward the food system (Min and Krochta, 2005). In the present study, peptidic/protein active compounds have been used to develop starch films with antimicrobial properties, 
on the basis of previous research. Butter milk, lactoferrin and lysozyme (proteic substances) and Ethyl Lauroyl Arginate (LAE) have been combined with starch, using different strategies to obtain active, biodegradable films. In the next section, the main findings concerning the use of these compounds in the development of active films are summarised. Buttermilk has previously been reported to exhibit antioxidant properties (Wong and Kitts, 2003). More specifically, the breaking of the fat globule membrane during processing releases a high quantity of proteins and membrane peptides with bioactive properties (Affolter et al., 2010). No previous studies into its antimicrobial properties have been reported, but it constitutes a by-product whose revalorization through its use in active packaging could be of great interest.

\subsubsection{Use of lactoferrin, lysozyme and ethyl lauroyl arginate (LAE) as antimicrobial compounds}

Different authors have studied the antimicrobial properties of enzymes, such as lysozyme and lactoferrin, either isolated or forming part of polymer films. Some of the recent studies into their application in active films are summarized in Table I. 3.

Lysozyme (LZ) is a globular protein whose polypeptide chain consists of 129 amino acids and has a molecular weight of, approximately, $14.4 \mathrm{kDa}$. Its four inner disulphide bridges (S-S) confer a high degree of thermal stability on LZ. Moreover, it consists of a very stable protein over a wide range of both $\mathrm{pH}$ and temperature, due to its high isoelectric point $(\mathrm{IP}=11)$, being positively charged at the $\mathrm{pH}$ of most food products (Barbiroli et al., 2016). Although LZ is abundant in a wide number of secretions (tears, milk, mucus, etc.), the chicken type is the most common one (Barbiroli et al., 2016; Corradini et al., 2013). Hen egg LZ is a widely used enzyme authorized for food preservation in the European Union (E1105) and considered as GRAS (Generally Recognized As Safe) by the Food and Drug Administration (FDA) in U.S.A (Colak et al., 2015). The antimicrobial activity of $L Z$ is based on its enzymatic activity against beta 1-4 glycosidic linkages between $\mathrm{N}$-acetylmuramic acid and $\mathrm{N}$-acetylglucosamine found in peptidoglycan (Barbiroli et al., 2016; Irkin and Esmer, 2015; Güçbilmez et al., 2007). The hydrolysis of the peptidoglycan, which is the major component of the cell wall of both Gram positive and Gram negative bacteria, can damage the structural integrity of the cell wall, resulting in the lysis of bacterial cells (Irkin and Esmer, 2015). However, LZ is less effective against Gram negative bacteria, since the peptidoglycan is shielded by the 
lipopolysaccharidic layer of the outer membrane (Callewaert et al., 2011; Benkerroum, 2008; Güçbilmez et al., 2007).

LZ has been widely used as an antimicrobial enzyme to develop active packaging (Güçbilmez et al., 2007). Specifically, it has been incorporated into a great variety of polymeric materials, leading to the obtaining of effective antimicrobial films. Corradini et al. (2013) developed an active coating for PET films based on polyvinyl alcohol (PVOH) and tetraethoxysilane (TEOS) and LZ, which exhibit antimicrobial activity against Micrococcus lysodeikticus. The incorporation of LZ into chitosan films has also been reported to improve the antimicrobial effectiveness of the films. Park et al. (2004) observed an enhancement in the inhibition efficacy of chitosan films against both Streptococcus faecalis and E. coli, while Duan et al. (2007) also reported that chitosan films and coatings were more effective when incorporating LZ. These were applied for mozzarella cheese preservation, which was inoculated with different bacteria (E. coli, $P$. fluorescens, and L. monocytogenes) as well as mould and yeast. The incorporation of LZ into protein-based films has also been proven to be a good strategy with which to obtain antimicrobial packaging materials. Zein films containing LZ have yielded effective antimicrobial films against $L$. innocua (Arcan and Yemenicioglu, 2013), as well as against E. coli and Bacillus subtilis, in combination with EDTA (Güçbilmez et al., 2007). Colak et al. (2015) obtained sodium caseinate-based antimicrobial films containing lysozyme by extrusion. Antimicrobial activity against Micrococcus luteus was observed when pellets were dissolved in the medium, but it was not detected for the films containing LZ through the disk diffusion method. This was attributed to the lack of release or to an insufficient amount of the enzyme. Fabra et al. (2014) incorporated LZ into pea protein and corn starch films, separately, and observed that both protein and starch matrices were effective at controlling L.monocytoneges growth at $10^{\circ} \mathrm{C}$. However, LZ seemed to lose its antimicrobial activity at room temperature. Nam et al. (2004) obtained pea starch antimicrobial films containing LZ using extrusion. The antimicrobial activity of the extrudates was demonstrated against Brochotrix thermosphacta B2, a representative Gram positive bacterium, which causes food spoilage on vacuum packaged refrigerated meat products. Carbohydrate-protein blend films carrying LZ have also been studied. Dekina et al. (2016) incorporated LZ into gelatin/sodium carboxymethyl cellulose films, which was effective at inhibiting the growth of $S$. aureus, $P$. aeruginosa, E. coli and $C$. albicans.

As commented on above, the outer membrane of Gram negative bacteria interferes with the antimicrobial action of LZ, which constitutes a drawback for those food products 
mainly contaminated with these bacteria, such as meat-based products commonly spoiled by Enterobacteriaceae and Pseudomonadaceae,(Coma, 2008). The combination of LZ with detergents and chelators, which lead to the destabilization of the outer membrane in Gram negative bacteria, has been pointed out as being a successful strategy with which to extend the activity of LZ (Branen \& Davidson, 2004; Gill \& Holley, 2000). Its combination with EDTA, one of the most widely used chelators, has been effectively proven (Güçbilmez et al., 2007). However, the replacement of EDTA by lactoferrin (LF), an iron binding protein naturally present in milk (Barbiroli et al., 2016), has been studied in order to obtain active packaging materials wholly based on natural antimicrobial compounds (Barbiroli et al., 2012; Brown et al., 2008).

LF is an $80 \mathrm{kDa}$ glycoprotein consisting of 700 amino acids, with the ability of binding and transferring $\mathrm{Fe}^{3+}$ ions (Barbiroli et al., 2016). Among the wide range of activities reported, such as immunoregulatory and anti-cancer, LF has been previously reported to show antimicrobial activity against a large variety of Gram positive and Gram negative bacteria (Drago, 2006; Padrão et al., 2016; Pan et al., 2007). Its antimicrobial capacity is caused by two different and independent mechanisms: the bacteriostatic activity based on its iron-ion binding ability, which makes this nutrient unavailable for bacteria (Arnold \& Cole, 1977; Reyes et al., 2005), and the bactericidal activity related to its direct interaction with the outer membrane of Gram negative bacteria (Garcia-Montoya et al., 2012; Liceaga-Gesualdo et al., 2001). More concretely, the large cationic patches present on LF surface (Jenssen and Hancock, 2009), permits it to interact directly with the anionic lipid A, a component of the lipopolysaccharide (LPS) membrane in Gram negative bacteria, thus altering the outer membrane permeability and causing the release of the LPS (Barbiroli et al., 2016).

Despite the reported antimicrobial effectiveness of LF, the available research into its application on active packaging is still reduced, either when applied alone or in combination with other antimicrobial agents, such as LZ. Regarding its combined application, Barbiroli et al. (2012) obtained and characterized a cellulose-based active packaging material incorporating both LZ and LF, and observed a synergistic effect against common food contaminants when they were simultaneously released. The obtained material was also effective at preserving ready-to-eat veal meat, "carpaccio". Brown et al. (2008) also studied the combined effects of LF with LZ and observed that, although chitosan films containing LF were ineffective at controlling the growth of the pathogenic bacteria tested, E.coli and L.monocytogenes, its combination with LZ led to inhibitory effects comparable to, or even improving on, those observed for EDTA-LZ 
blends, at higher concentrations. As concerns the application of LF on its own for the purposes of obtaining active films, Min and Krochta (2005) obtained whey protein isolate based films containing LF and LF hydrolysate and observed a growth inhibition capacity for Penicillium commune. Quintieri et al. (2013) immobilized LF, and a derived peptide (LfcinB), on plasma deposited ethylene/acrylic acid coatings. Although both formulations showed antimicrobial activity against strains belonging to three Pseudomonas species, LfcinB exhibited higher antimicrobial activity than LF. Padrão et al. (2016) obtained bacterial cellulose films modified by LF adsorption, which were effective at controlling the viability of both E.coli and S.aureus in vitro. When applied for fresh sausage preservation, the bactericidal efficacy was greater for $E$. coli than for $S$. aureus, although the results were contrary to those in the in vitro study. This is a common trend when comparing the effectiveness of an antimicrobial compound in vitro or when applied in real food systems, pointing to the great influence of the food matrices on the antimicrobial effect. Hence, the antimicrobial effectiveness is closely related not only with the target microorganisms, but also with the interactive effects of a number of factors coming from the food system, such as $\mathrm{pH}$, water activity, fat and protein content, or its nature microflora (Han, 2005). On the other hand, Balçao et al., 2013 developed lipid nanovesicles encasing lactoferrin and observed antimicrobial effectiveness against Gram positive bacteria (S. aureus, L. innocua, B. cereus) and C. albicans; however, although the Gram negative bacteria tested (Salmonella sp, E. coli, Pseudomonas fluorescens) were not inhibited, they might have destabilized their outer membrane.

Ethyl-N $\alpha$-dodecanoyl-L-arginate hydrochloride (LAE) is a potent food antimicrobial agent with a wide spectrum of antimicrobial activity (Muriel-Galet et al., 2014). Chemically, LAE is a synthetic cationic surfactant derived from lauric acid, L-arginine and ethanol(Rubilar et al., 2016; Ma et al., 2016; Muriel-Galet et al., 2015), and its hydrolysis in the digestive tract transforms LAE into all its constituents (Bakal and Diaz, 2005; Kashiri et al., 2016, Muriel-Galet et al., 2012). On this basis, the United States Food and Drug Administration (USDA, 2005) and the European Food Safety Agency (EFSA) approved LAE as a Generally Recognized As Safe (GRAS) food additive (Rubilar et al., 2016). More specifically, the Commission Regulation (EU 506/2014) authorized the use of LAE to be applied on heat treated meat products as a food additive with the assigned number $\mathrm{E}$ 243 , with a maximum dose of $160 \mathrm{mg} / \mathrm{kg}(\mathrm{ppm})$, while FDA permits its application as a food preservative at a concentration of up to $200 \mathrm{ppm}$ (Muriel-Galet et al., 2015). LAE has exhibited a marked antimicrobial effectiveness, even applied at a low dose, against moulds, Gram positive and Gram negative bacteria (Pezo et al., 2012), accomplished by its interaction with the negatively charged microbial proteins present in cell membranes 
or enzymatic systems, causing protein denaturation, jointly with the inhibition of cell growth or even death (Luchansky et al., 2005; Pezo et al., 2012; Rodriguez et al., 2004).

LAE has been widely studied as an antimicrobial agent with the aim of preserving food against microbial spoilage. Specifically, it has been tested in several food systems, either by coating, spraying or directly incorporating it into food formulations, for the purposes of avoiding foodborne infections, mainly listeriosis caused by Listeria monocytogenes, in roasted turkey (Jiang et al., 2011), cold-smoked salmon (Kang et al., 2014), frankfurters (Martín et al., 2010; Porto-Fett et al., 2010), cheese (Soni et al., 2012) or cooked cured ham (Stopforth et al., 2010). Additionally, Nair et al. (2014) also tested how LAE affected the growth control of Campylobacter jejuni in chicken breast fillets. Ma et al. (2013) observed the effectiveness of LAE at preserving reduced fat milk and Terjung et al. (2014) observed the effect of LAE addition on the growth of Listeria innocua in meat emulsions. On the other hand, the combination of LAE with other antimicrobial compounds has also been assessed. Chang et al. (2015) obtained a nanoemulsion based on the combination of LAE with thyme oil, and pointed out the synergistic activity between both antimicrobial agents. Pattanayaiying et al. (2014) observed an increased inhibition capacity when nisin Z was applied in combination with LAE, against both Gram positive and Gram negative bacteria.

Despite the LAE's wide and strong antimicrobial activity and its effectiveness at controlling food spoilage, few research studies are available that deal with its incorporation into polymeric matrices with the aim of obtaining active packaging for food preservation. The recent contributions in this sense are summarized in Table I. 3.

Higueras et al. (2013) incorporated LAE into chitosan films, and observed a significant increase of the antimicrobial activity, tested in vitro, of chitosan films against a wide variety of microorganisms. In addition, the obtained films were also effective at reducing the common microbiota of fresh chicken, which makes them a promising material for the packaging of fresh poultry products. More recently, Ma et al. (2016) also observed that the incorporation of LAE into chitosan films greatly enhances the bacterial growth inhibition of the films. The incorporation of LAE into EVOH films has also been studied. Specifically, the incorporation of 5 and $10 \%$ wt of LAE with respect to the dry polymer produced a total growth inhibition of Listeria monocytogenes, Escherichia coli, and Salmonella enterica. However, a higher proportion would be required to produce a total growth inhibition of Listeria monocytogenes and Salmonella enterica when applied into infant formula (Muriel-Galet et al., 2012). EVOH films containing LAE have also proven to be effective at preserving chicken stock and surimi sticks by reducing the growth of 
their natural flora and the inoculated Listeria monocytogenes and Escherichia coli, increasing the safety of the products after the package is opened (Muriel-Galet et al., 2015). LAE has also been successfully incorporated into other polymeric matrices, such as zein (Kashiri et al., 2016) and pullulan (Pattanayaiying et al., 2015), leading to a decrease in the counts or even a total growth inhibition of foodborne pathogens. LAE has also been used as an active layer to be applied on packaging materials. In this sense, Guo et al. (2014) developed newly designed antimicrobial coatings based on chitosan solutions containing LAE, either to be applied directly on foods or for making double layer antimicrobial PLA films. The growth of $L$. innocua in ready-to-eat deli meat product was significantly reduced, and an increase in the LAE concentration in the coating solutions led to an enhancement of the antilisterial effectiveness. Theinsathid et al. (2012) also developed environmentally friendly packaging based on LAE-coated PLA films, and observed that the films were effective at reducing the initial levels of Listeria monocytogenes and Salmonella typhimurium on the surface of cooked sliced ham. Otero et al. (2014) applied a LAE-coating onto PET and PP films and observed an influence of the polymer on the antimicrobial effectiveness. An in vitro test against two strains of E.coli demonstrated how LAE-coated-PET films were slightly more effective than LAEcoated-PP films. Additionally, when the films were tested for Zamorano cheese preservation, LAE-coated-PP films were less effective against the inoculated E.coli strain than that predicted from in vitro tests. As commented on above, each food system provides specific characteristics that could actively interfere with the antimicrobial action of the active agent.

For all antimicrobial compounds, their release from the polymeric matrix is a complex phenomenon that has a marked influence on the effectiveness of the films. This diffusion phenomenon depends on different factors, including the method employed to form the film, the chemical properties of the compound (volatility and polarity), the chemical nature of the polymer (hydrophobicity and hydrophilicity), their molecular weight, and, mainly, the chemical interactions between the antimicrobial agent and polymer chains, which may introduce changes into the arrangement of the polymeric network of the film. In addition, environmental factors, such as storage conditions (temperature and relative humidity), as well as food composition, water activity $\left(a_{w}\right)$ and $\mathrm{pH}$ of the food, also play an important role in the active agents' release and action (Kuorwel et al., 2013, SánchezGonzález et al., 2015)

In this sense, as commented on above, the high degree of interaction between peptidic antimicrobial agents containing starch and starch/protein blend matrices may interfere in 
the release of the active compounds, resulting in a decrease of the antimicrobial capacity of the active films. Fabra et al. (2014) pointed out the interaction of lysozyme when incorporated into starch films, which may affect the antimicrobial effectiveness of the films. Likewise, Higueras et al. (2013) observed the influence of LAE concentration on its release kinetics from chitosan films; the higher the LAE concentration in the polymeric matrix, the slower the diffusion, due to an antiplasticizing effect. As a result of the greater polymer cohesion promoted by the addition of some active substances, the transport processes may be affected (López-Rubio et al., 2009).

In addition, the high molecular weight of the antimicrobial agents could disable them to diffuse into the food model, coherently with the results obtained by Fabra et al. (2014) for LZ incorporated into both starch and protein films. Likewise, the fact that LF and its hydrolysate are large in size in comparison with the small antimicrobial compounds, such as nisin, pediocin, and lacticin, could lead to a slower diffusion from the polymer matrices to the film surface, limiting their antimicrobial effectiveness (Min and Khrocta, 2005). Quintieri et al. (2013) also observed a higher degree of activity for LF-derived peptides, which could be due to both the smaller size and easier release and diffusion of the antimicrobial compound.

$\mathrm{LAE}$, and especially both $\mathrm{LZ}$ and $\mathrm{LF}$, are active agents with high molecular weight, compared with other compounds that are usually incorporated as antimicrobial agents, such as the EO compounds. They are highly compatible with the starch and starch/gelatin blend-based polymeric matrices used in the present study, due to their composition in amino groups and the amphiphilic nature, which could greatly interfere with their release and antimicrobial effectiveness. Nonetheless, as hydrophilic polymers, starch and gelatin are able to gain a large amount of water, leading to the swelling and plasticization of the polymer network, increasing its flexibility while reducing interchain cohesion energy. This, consequently, results in an increase in the mass transport kinetics within the matrix (Higueras et al., 2013). Several authors have pointed out the higher diffusion of LAE from hydrophilic matrices in comparison with the more hydrophobic ones, thus, being less able to absorb water (Higueras et al., 2013; Kashiri et al., 2016). In this sense, given their capacity to enhance polymer cohesion and their ability to be released towards the foodstuff, the incorporation of LAE, LZ and LF into starch or starch/gelatin blends may be a good strategy with which to obtain active biodegradable packaging for food preservation, thus extending the shelf-life. 
Table I. 3. Recent studies using lactoferrin, lysozyme or LAE in active films.

\begin{tabular}{|c|c|c|c|c|}
\hline Active compound & $\begin{array}{l}\text { Biopolymer } \\
\text { Matrix }\end{array}$ & $\begin{array}{c}\text { Active ratio (wt. \% } \\
\text { with respect polymer) }\end{array}$ & Antimicrobial test & Reference \\
\hline \multirow{9}{*}{ Lysozyme } & Zein & 66.9 & In vitro. Listeria innocua, $13 \cdot 10^{7} \mathrm{CFU} / \mathrm{mL}$ & $\begin{array}{l}\text { Arcan and } \\
\text { Yemenicioglu, } \\
2013\end{array}$ \\
\hline & $\begin{array}{l}\text { Corn Starch } \\
\text { Pea Protein }\end{array}$ & $0,5,7.5,10$ & In vitro. L.monocytogenes, $10^{2} \mathrm{CFU} / \mathrm{cm}^{2}$ & $\begin{array}{l}\text { Fabra et al., } \\
2014\end{array}$ \\
\hline & Sodium Caseinate & 1 & In vitro. Micrococcus luteus. & $\begin{array}{l}\text { Colak et al., } \\
\quad 2015\end{array}$ \\
\hline & $\begin{array}{l}\text { PVOH/tetraethoxysilane } \\
\text { (TEOS) }\end{array}$ & 6.25 & In vitro. Micrococcus lysodeikticus s & $\begin{array}{l}\text { Corradini et } \\
\text { al., } 2013\end{array}$ \\
\hline & $\begin{array}{l}\text { Gelatin/Carboxymethyl } \\
\text { Cellulose }\end{array}$ & 22 & $\begin{array}{c}\text { In vitro. S.aureus, P.aeruginosa, E.coli and } \\
\text { Candida albicans } 10^{7} \mathrm{CFU} / \mathrm{mL}\end{array}$ & $\begin{array}{l}\text { Dekina et al., } \\
2016\end{array}$ \\
\hline & Chitosan & $0-60$ & $\begin{array}{c}\text { In vivo. Mozzarella cheese inoculated with } E \text {. } \\
\text { coli, } P \text {. fluorescens, and } L \text {. monocytogenes } \\
\left(10^{6} \mathrm{CFU} / \mathrm{mL}\right) \text {, and mould and yeast }\left(10^{4}\right. \\
\text { CFU/mL) }\end{array}$ & $\begin{array}{l}\text { Duan et al., } \\
2007\end{array}$ \\
\hline & Zein & $2.4-4.9$ & In vitro. Escherichia coli, Bacillus subtilis & $\begin{array}{l}\text { Güçbilmez et } \\
\text { al., } 2007\end{array}$ \\
\hline & Pea Starch & 1 & In vitro. Brochotrix thermosphacta B2. & $\begin{array}{l}\text { Nam et al., } \\
2007\end{array}$ \\
\hline & Chitosan & $0,20,60,100$ & $\begin{array}{c}\text { In vitro. Escherichia coli, Streptococcus } \\
\text { faecalis } 10^{7} \mathrm{CFU} / \mathrm{mL}\end{array}$ & $\begin{array}{l}\text { Park et al., } \\
2004\end{array}$ \\
\hline \multirow{2}{*}{ Lactoferrin/Lysozyme } & Cellulose & 10 & $\begin{array}{l}\text { In vitro. Escherichia coli and Listeria innocua, } \\
\mathrm{OD}_{600}=0.200 \\
\text { In vivo. Total Aerobic Counts of ready-to-eat } \\
\text { veal meat,"carpaccio". }\end{array}$ & $\begin{array}{l}\text { Barbiroli et al., } \\
\qquad 2012\end{array}$ \\
\hline & Chitosan & $\begin{array}{l}\text { Lysozyme: } 46.9 \\
\text { Lactoferrin: } 13.3,26.7 \\
53.3\end{array}$ & $\begin{array}{c}\text { In vitro. Escherichia coli and Listeria } \\
\text { monocytogenes }\end{array}$ & $\begin{array}{l}\text { Brown et al., } \\
2008\end{array}$ \\
\hline
\end{tabular}




\begin{tabular}{|c|c|c|c|c|}
\hline \multirow{4}{*}{ Lactoferrin } & $\begin{array}{l}\text { Whey Protein Isolate } \\
\text { (WPI) }\end{array}$ & 0.1 & $\begin{array}{l}\text { In vitro. Penicillium comune, } 10^{3}-10^{4}-10^{5} \\
\text { spores/plate and } 10^{5}-10^{6}-10^{7} \text { spores } / \mathrm{mL}\end{array}$ & $\begin{array}{c}\text { Min and } \\
\text { Khrocta, } 2005\end{array}$ \\
\hline & Ethylene/acrylic acid & $170 \mu \mathrm{g} / \mathrm{mL}^{*}$ & $\begin{array}{c}\text { In vitro. Pseudomonas fragi } 23 \mathrm{~A}, \\
\text { Pseudomonas gessardii PS36 and } \\
\text { Pseudomonas fluorescens TO95 } 10^{2}-10^{3} \\
\text { CFU/mL }\end{array}$ & $\begin{array}{l}\text { Quintieri et al., } \\
\qquad 2013\end{array}$ \\
\hline & & & $\begin{array}{l}\text { In vitro. Escherichia coli, Staphillocuccus } \\
\text { aureus } 1.510^{6} \mathrm{CFU} / \mathrm{mL} .\end{array}$ & \multirow[b]{2}{*}{$\begin{array}{l}\text { Padrão et al., } \\
2016\end{array}$} \\
\hline & Bacterial cellulose & $10 \mathrm{mg} / \mathrm{mL}^{*}$ & $\begin{array}{c}\text { In vivo. Sausages inoculated with Escherichia } \\
\text { coli }\left(9.510^{5} \mathrm{CFU} / \mathrm{mL}\right) \text { and Staphillocuccus } \\
\text { aureus }\left(1.010^{6} \mathrm{CFU} / \mathrm{mL}\right)\end{array}$ & \\
\hline \multirow{6}{*}{ LAE } & $\begin{array}{l}\text { Chitosan-LAE coating } \\
\text { in PLA films }\end{array}$ & $20,50,100,200$ & $\begin{array}{l}\text { In vivo. Listeria innocua inoculated in ready-to- } \\
\text { eat turkey meat, } 6-7 \mathrm{CFU} / \mathrm{cm}^{2} \text {. }\end{array}$ & $\begin{array}{l}\text { Guo et al., } \\
2014\end{array}$ \\
\hline & Chitosan & $0.7,3.5,6.9$ & $\begin{array}{c}\text { In vitro. Escherichia coli, Staphylococcus } \\
\text { aureus, Listeria monocytogenes, Salmonella } \\
\text { enterica and Pseudomonas putida; Candida } \\
\text { utilis Saccharomyces cerevisiae var. } \\
\text { Ellipsoideus and Torulopsis pinus; Aspergillus } \\
\text { niger, Penicillium chrysogenum and } \\
\text { Cladosporium cladosporioides. }\end{array}$ & \multirow[t]{2}{*}{$\begin{array}{l}\text { Higueras et } \\
\text { al., } 2013\end{array}$} \\
\hline & & & $\begin{array}{l}\text { In vivo. Mesophiles and psychrophiles, Yeasts } \\
\text { and fungi, Pseudomonas spp., Coliforms, } \\
\text { Lactic acid bacteria, Hydrogen sulfide- } \\
\text { producing bacteria in chicken breast fillets. }\end{array}$ & \\
\hline & Zein & 5,10 & $\begin{array}{c}\text { In vitro. Escherichia coli and Listeria } \\
\text { monocytogenes, } 10^{3} \mathrm{CFU} / \mathrm{mL}\end{array}$ & $\begin{array}{l}\text { Kashiri et al., } \\
\quad 2016\end{array}$ \\
\hline & Chitosan & 10,20 & $\begin{array}{l}\text { In vitro. Escherichia coli, S.enterica and } \\
\text { Listeria monocytogenes, } 10^{6} \mathrm{CFU} / \mathrm{mL}\end{array}$ & $\begin{array}{l}\text { Ma et al., } \\
2016\end{array}$ \\
\hline & $\mathrm{EVOH}$ & $0.25,1,5,10$ & $\begin{array}{l}\text { In vitro. Escherichia coli, S.enterica and } \\
\text { Listeria monocytogenes, } 10^{3} \mathrm{CFU} / \mathrm{mL} \\
\text { In vivo. L. monocytogenes and S. enterica } \\
\text { inoculated in infant formula, } 10^{3} \mathrm{CFU} / \mathrm{mL}\end{array}$ & $\begin{array}{l}\text { Muriel-Galet et } \\
\quad \text { al., } 2012\end{array}$ \\
\hline
\end{tabular}


In vitro. Escherichia coli and Listeria monocytogenes $10^{7} \mathrm{CFU} / \mathrm{mL}$

$\mathrm{EVOH}$

5,10

polypropylene (PP)-

and polyethylene

terephthalate (PET)

films

LAE

Pullulan

20

LAE-coated PLA films

$0.07,0.14,0.28,2.6$

In vivo. L.monocytogenes and E.coli, Total Enteriobacteria, Lactic Acid Bacteria, Tota

Muriel-Galet et

Aerobic Baceria Total Psychrotrophic

al., 2015

Bacteria and Pseudomonas in Chicken stock and Surimi sticks.

In vitro. E.coli, $10^{8} \mathrm{CFU} / \mathrm{mL}$

In vivo. E.coli inoculated in Zamorano sheep cheese, $10^{4} \mathrm{CFU} / \mathrm{g}$.

Otero et al., 2014

In vitro. S. Typhimurium, S. Enteritidis, $L$. monocytogenes, S. aureus, E. coli and $B$. thermosphacta, $10^{6} \mathrm{CFU} / \mathrm{mL}$

In vivo. S. Typhimurium, S. Enteritidis, $L$. monocytogenes, S. aureus, E. coli and $B$. thermosphacta in raw turkey brest, deli ham, and raw beef, $10^{5} \mathrm{CFU} / \mathrm{cm}^{2}$

In vitro. Listeria monocytogenes and

Salmonella typhimorium, $10^{7} \mathrm{CFU} / \mathrm{mL}$

In vivo. Listeria monocytogenes and Salmonella typhimorium inoculated in ham
Theinsathid et

Pattanayaiying

et al., 2015

al., 2012

*activated surface by introducing the film into a stock with the indicated concentration. 


\section{REFERENCES}

Acosta, S., Jiménez, A., Cháfer, M., González-Martínez, C., \& Chiralt, A. (2015). Physical properties and stability of starch-gelatin based films as affected by the addition of esters of fatty acids. Food Hydrocolloids, 49, 135-143.

Acosta, S., Chiralt, A., Santamarina, P., Rosello, J., González-Martínez, C., \& Cháfer, M. (2016). Antifungal films based on starch-gelatin blend, containing essential oils. Food Hydrocolloids, 61, 233-240.

Affolter, M., Grass, L., Vanrobaeys, F., Casado, B., \& Kussmann, M. (2010). Qualitative and quantitative profiling of the bovine milk fat globule membrane proteome. Journal of proteomics, 73(6), 1079-1088.

Ahmed, S., \& Ikram, S. (2016). Chitosan and gelatin based biodegradable packaging films with UV-light protection. Journal of Photochemistry and Photobiology B: Biology, $163,115-124$.

Alexandre, E. M. C., Lourenço, R. V., Bittante, A. M. Q. B., Moraes, I. C. F., \& do Amaral Sobral, P. J. (2016). Gelatin-based films reinforced with montmorillonite and activated with nanoemulsion of ginger essential oil for food packaging applications. Food Packaging and Shelf Life, 10, 87-96.

Al-Hassan, A. A., \& Norziah, M. H. (2012). Starch-gelatin edible films: water vapor permeability and mechanical properties as affected by plasticizers. Food Hydrocolloids, 26(1), 108-117

Amass, W., Amass, A., \& Tighe, B. (1998). A review of biodegradable polymers: uses, current developments in the synthesis and characterization of biodegradable polyesters, blends of biodegradable polymers and recent advances in biodegradation studies. Polymer International, 47(2), 89-144.

Ansorena, M. R., Zubeldía, F., \& Marcovich, N. E. (2016). Active wheat gluten films obtained by thermoplastic processing. LWT-Food Science and Technology, 69, 47-54.

Arcan, I., \& Yemenicioğlu, A. (2013). Development of flexible zein-wax composite and zein-fatty acid blend films for controlled release of lysozyme. Food Research International, 51(1), 208-216.

Arnold, R. R., \& Cole, M. F. (1977). A bactericidal effect for human lactoferrin. Science, 197(4300), 263-265.

Arvanitoyannis, I., \& Biliaderis, C. G. (1997). Physical properties of polyol-plasticized edible films made from sodium caseinate and soluble starch blends. Food chemistry, 62(3), 333-342. 
Arvanitoyannis, I., Nakayama, A., \& Aiba, S. I. (1998). Edible films made from hydroxypropyl starch and gelatin and plasticized by polyols and water. Carbohydrate Polymers, 36(2), 105-119.

Arfat, Y. A., Ahmed, J., Hiremath, N., Auras, R., \& Joseph, A. (2017). Thermomechanical, rheological, structural and antimicrobial properties of bionanocomposite films based on fish skin gelatin and silver-copper nanoparticles. Food Hydrocolloids, 62, 191-202.

Atarés, L., \& Chiralt, A. (2016). Essential oils as additives in biodegradable films and coatings for active food packaging. Trends in Food Science \& Technology, 48, 51-62.

Averous, L. (2004). Biodegradable multiphase systems based on plasticized starch: a review. Journal of Macromolecular Science, Part C: Polymer Reviews, 44(3), 231-274.

Azeredo, H. M., \& Waldron, K. W. (2016). Crosslinking in polysaccharide and protein films and coatings for food contact-A review. Trends in Food Science \& Technology, 52, 109-122.

Azevedo, V. M., Borges, S. V., Marconcini, J. M., Yoshida, M. I., Neto, A. R. S., Pereira, T. C., \& Pereira, C. F. G. (2016). Effect of replacement of corn starch by whey protein isolate in biodegradable film blends obtained by extrusion. Carbohydrate Polymers.

Bakal G \& Diaz A (2005) The lowdown on lauric arginate. Food quality (Feb./March), 6061.

Balaguer, M. P., Villanova, J., Cesar, G., Gavara, R., \& Hernandez-Munoz, P. (2015). Compostable properties of antimicrobial bioplastics based on cinnamaldehyde crosslinked gliadins. Chemical Engineering Journal, 262, 447-455.

Balakrishnan, B., \& Jayakrishnan, A. (2005). Self-cross-linking biopolymers as injectable in situ forming biodegradable scaffolds. Biomaterials, 26(18),3941-3951.

Balcão, V. M., Costa, C. I., Matos, C. M., Moutinho, C. G., Amorim, M., Pintado, M. E., ... \& Teixeira, J. A. (2013). Nanoencapsulation of bovine lactoferrin for food and biopharmaceutical applications. Food Hydrocolloids, 32(2), 425-431.

Baldwin, E. A., Nisperos-Carriedo, M. O., \& Baker, R. A. (1995). Edible coatings for lightly processed fruits and vegetables. HortScience, 30(1), 35-38.

Barbiroli, A., Bonomi, F., Capretti, G., lametti, S., Manzoni, M., Piergiovanni, L., et al. (2012). Antimicrobial activity of lysozyme and lactoferrin incorporated in cellulose-based food packaging. Food Control, 26(2), 387-392.

Barbiroli, A., Farris, S. \& Rollini, M. (2016). Chapter 48 - Combinational approaches for antimicrobial packaging: lysozyme and lactoferrin. Antimicrobial food packaging (pp. 589-97). Elsevier Inc. Adademic-Press.

Barnett, I., (2011). Packaging Solutions Throughout the Supply Chain: Technology, Trends and Future Outlook. Business Insight, London. 
Basiak, E., Galus, S., \& Lenart, A. (2015). Characterisation of composite edible films based on wheat starch and whey-protein isolate. International Journal of Food Science \& Technology, 50(2), 372-380.

Benkerroum, N. (2008). Antimicrobial activity of lysozyme with special relevance to milk. African Journal of Biotechnology, 7(25).

Bertuzzi, M. A., Vidaurre, E. C., Armada, M., \& Gottifredi, J. C. (2007). Water vapor permeability of edible starch based films. Journal of food engineering, 80(3), 972-978.

Bourtoom, T. (2008). Edible films and coatings: characteristics and properties. International Food Research Journal, 15(3), 237-248.

Branen, J. K., \& Davidson, P. M. (2004). Enhancement of nisin, lysozyme, and monolaurin antimicrobial activities by ethylendiaminetetraacetic acid and lactoferrin. International Journal of Food Microbiology, 90, 63-74.

Brown, C. A., Wang, B., \& Oh, J. H. (2008). Antimicrobial activity of lactoferrin against foodborne pathogenic bacteria incorporated into edible chitosan film. Journal of food protection, 71(2), 319-324.

Byun, Y., \& Kim, Y. T. (2014). Chapter 14 - Bioplastics for food packaging: Chemistry and physics. In J. H. Han (Ed.), Innovations in food packaging (2nd ed., pp. 353-368). San Diego: Academic Press.

Callewaert, L., Walmagh, M., Michiels, C. W., \& Lavigne, R. (2011). Food applications of bacterial cell wall hydrolases. Current opinion in biotechnology, 22(2), 164-171.

Campos, C. A., Gerschenson, L. N., \& Flores, S. K. (2011). Development of edible films and coatings with antimicrobial activity. Food and Bioprocess Technology, 4(6), 849-875.

Cano, A., Fortunati, E., Chafer, M., González-Martínez, C., Chiralt, A., \& Kenny, J. M. (2015). Effect of cellulose nanocrystals on the properties of pea starch-poly (vinyl alcohol) blend films. Journal of materials science, 50(21), 6979-6992.

Cao, X., Chang, P. R., \& Huneault, M. A. (2008). Preparation and properties of plasticized starch modified with poly ( $\varepsilon$-caprolactone) based waterborne polyurethane. Carbohydrate Polymers, 71(1), 119-125.

Cazón, P., Velazquez, G., Ramírez, J. A., \& Vázquez, M. (2016). Polysaccharide-based films and coatings for food packaging: A review.Food Hydrocolloids.

Chandra, R., \& Rustgi, R. (1998). Biodegradable polymers. Progress in polymer science, 23(7), 1273-1335.

Chang, Y., McLandsborough, L., \& McClements, D. J. (2015). Fabrication, stability and efficacy of dual-component antimicrobial nanoemulsions: essential oil (thyme oil) and cationic surfactant (lauric arginate). Food chemistry, 172, 298-304.

Chen, H. (2002). Formation and properties of casein films and coatings. Protein-based films and coatings, 181-211. 
Chen, H., Hu, X., Chen, E., Wu, S., McClements, D. J., Liu, S., ... \& Li, Y. (2016). Preparation, characterization, and properties of chitosan films with cinnamaldehyde nanoemulsions. Food Hydrocolloids, 61, 662-671.

Chiang, B. Y., \& Johnson, J. A. (1977). Gelatinization of starch in extruded products [Wheat flour]. Cereal Chemistry (USA).

Chinma, C. E., Ariahu, C. C., \& Abu, J. O. (2012). Development and characterization of cassava starch and soy protein concentrate based edible films. International Journal of Food Science \& Technology, 47(2), 383-389.

Ciannamea, E. M., Stefani, P. M., \& Ruseckaite, R. A. (2016). Properties and antioxidant activity of soy protein concentrate films incorporated with red grape extract processed by casting and compression molding. LWT-Food Science and Technology, 74, 353-362.

Colak, B. Y., Peynichou, P., Galland, S., Oulahal, N., Assezat, G., Prochazka, F., \& Degraeve, P. (2015). Active biodegradable sodium caseinate films manufactured by blown-film extrusion: Effect of thermo-mechanical processing parameters and formulation on lysozyme stability. Industrial Crops and Products, 72, 142-151.

Coma, V. (2008). Bioactive packaging technologies for extended shelf life of meat-based products. Meat science, 78(1), 90-103.

Commission Regulation (EU) No 506/2014 of 15 May 2014 amending Annex II to Regulation (EC) No 1333/2008 of the European Parliament and of the Council and the Annex to Commission Regulation (EU) No 231/2012 as regards Ethyl lauroyl arginate as a preservative in certain heat-treated meat products Text with EEA relevance

Corradini, C., Alfieri, I., Cavazza, A., Lantano, C., Lorenzi, A., Zucchetto, N., \& Montenero, A. (2013). Antimicrobial films containing lysozyme for active packaging obtained by sol-gel technique. Journal of Food Engineering, 119(3), 580-587.

Correa, J. P., Molina, V., Sanchez, M., Kainz, C., Eisenberg, P., \& Massani, M. B. (2017). Improving ham shelf life with a polyhydroxybutyrate/polycaprolactone biodegradable film activated with nisin. Food Packaging and Shelf Life, 11, 31-39.

Davidson, P.M., Taylor, T.M., 2007. Chemical preservatives and natural antimicrobial compounds. In: Doyle, M.P., Beuchat, L.R. (Eds.), Food Microbiology: Fundamentals and Frontiers, third ed. ASM Press, Washington, DC, pp. 713-746.

De Lima Marques, J., Funck, G. D., da Silva Dannenberg, G., dos Santos Cruxen, C. E., El Halal, S. L. M., Dias, A. R. G., ... \& da Silva, W. P. (2017). Bacteriocin-like substances of Lactobacillus curvatus P99: characterization and application in biodegradable films for control of Listeria monocytogenes in cheese. Food Microbiology, 63, 159-163.

De Moraes Crizel, T., Costa, T. M. H., de Oliveira Rios, A., \& Flôres, S. H. (2016). Valorization of food-grade industrial waste in the obtaining active biodegradable films for packaging. Industrial Crops and Products, 87, 218-228.

De Moura, M. R., Aouada, F. A., Avena-Bustillos, R. J., McHugh, T. H., Krochta, J. M., \& Mattoso, L. H. (2009). Improved barrier and mechanical properties of novel 
hydroxypropyl methylcellulose edible films with chitosan/tripolyphosphate nanoparticles. Journal of Food Engineering, 92(4), 448-453.

De Oliveira Pizzoli, A. P., Marchiore, N. G., De Souza, S. J., de Freitas Santos, P. D., Gonçalves, O. H., Yamashita, F., ... \& Leimann, F. V. (2016). Antimicrobial PLA/TPS/gelatin sheets with enzymatically crosslinked surface containing silver nanoparticles. Journal of Applied Polymer Science, 133(8).

De Reynal, B., \& Multon, J. (2009). Additifs et auxiliaires de fabrication dans les industries agroalimentaires.

Dekina, S., Romanovska, I., Ovsepyan, A., Tkach, V., \& Muratov, E. (2016). Gelatin/carboxymethyl cellulose mucoadhesive films with lysozyme: Development and characterization. Carbohydrate polymers, 147, 208-215.

Drago, M. E. (2006). Actividades antibacterianas de lactoferrina. Enfermedades Infecciosas y Microbiología, 26(2), 58-63.

Du, Y. L., Cao, Y., Lu, F., Li, F., Cao, Y., Wang, X. L., \& Wang, Y. Z. (2008). Biodegradation behaviors of thermoplastic starch (TPS) and thermoplastic dialdehyde starch (TPDAS) under controlled composting conditions. Polymer Testing, 27(8), 924930.

Duan, J., Park, S. I., Daeschel, M. A., \& Zhao, Y. (2007). Antimicrobial chitosanlysozyme $(\mathrm{CL})$ films and coatings for enhancing microbial safety of mozzarella cheese. Journal of Food Science, 72(9), M355-M362.

Dutta, A., Raychaudhuri, U., \& Chakraborty, R. (2006). Biopolymers for food packaging. Indian food industry, 25(1), 33-40.

Elsser-Gravesen, D., \& Elsser-Gravesen, A. (2013). Biopreservatives. Advances in Biochemical Engineering/Biotechnology, 143, 29-49.

European-Bioplastics - $\quad$ Bioplastic materials. http://www.europeanbioplastics.org/bioplastics/materials/. Accessed on November 2016.

Fabra, M. J., Sánchez-González, L., \& Chiralt, A. (2014). Lysozyme release from isolate pea protein and starch based films and their antimicrobial properties. LWT-Food Science and Technology, 55(1), 22-26.

Fakhoury, F. M., Martelli, S. M., Bertan, L. C., Yamashita, F., Mei, L. H. I., \& Queiroz, F. P. C. (2012). Edible films made from blends of manioc starch and gelatin-Influence of different types of plasticizer and different levels of macromolecules on their properties. LWT-Food Science and Technology, 49(1), 149-154.

Fakhouri, F. M., Costa, D., Yamashita, F., Martelli, S. M., Jesus, R. C., Alganer, K., ... \& Innocentini-Mei, L. H. (2013). Comparative study of processing methods for starch/gelatin films. Carbohydrate polymers, 95(2), 681-689.

Fakhouri, F. M., Martelli, S. M., Caon, T., Velasco, J. I., \& Mei, L. H. I. (2015). Edible films and coatings based on starch/gelatin: Film properties and effect of coatings on 
quality of refrigerated Red Crimson grapes. Postharvest Biology and Technology, 109, 57-64.

Farris, S., Schaich, K. M., Liu, L., Piergiovanni, L., \& Yam, K. L. (2009). Development of polyion-complex hydrogels as an alternative approach for the production of bio-based polymers for food packaging applications: a review. Trends in food science \& technology, 20(8), 316-332.

Ferreira, A. R., Alves, V. D., \& Coelhoso, I. M. (2016). Polysaccharide-Based Membranes in Food Packaging Applications. Membranes, 6(2), 22.

Fiedorowicz, M., \& Para, A. (2006). Structural and molecular properties of dialdehyde starch. Carbohydrate Polymers, 63(3), 360-366.

Flieger, M., Kantorová, M., Prell, A., Řezanka, T., \& Votruba, J. (2003). Biodegradable Plastics from Renewable Sources. Folia Microbiologica, 48(1), 27-44.

Food Packaging Forum- Food Packaging Health, Food Packaging Materials. http://www.foodpackagingforum.org/. Accessed on November, 2016.

Francis Suh JK, Matthew HWT. (2000). Application of chitosan-based polysaccharide biomaterials in cartilage tissue engineering: a review. Biomaterials 21:2589-98.

Galus, S., Lenart, A., Voilley, A., \& Debeaufort, F. (2013). Effect of oxidized potato starch on the physicochemical properties of soy protein isolate-based edible films. Food Technology and Biotechnology, 51(3), 403.

Gao, P., Wang, F., Gu, F., Liang, J., Li, N., \& Ludescher, R. D. (2016). Preparation and characterization of zein thermo-modified starch films. Carbohydrate Polymers.

García, M. A., Martino, M. N., \& Zaritzky, N. E. (2000). Microstructural Characterization of Plasticized Starch-Based Films. Starch-Stärke, 52(4), 118-124.

García-Montoya, I. A., Cendón, T. S., Arévalo-Gallegos, S., \& Rascón-Cruz, Q. (2012). Lactoferrin a multiple bioactive protein: An overview. Biochimica Et Biophysica Acta (BBA) - General Subjects, 1820(3), 226-236.

Gardner, D. J., Oporto, G. S., Mills, R., \& Samir, M. A. S. A. (2008). Adhesion and surface issues in cellulose and nanocellulose. Journal of Adhesion Science and Technology, 22(5-6), 545-567.

Gennadios, A., \& Weller, C. L. (1990). Edible films and coatings from wheat and corn proteins. Food Technology.

Gill, A. O., \& Holley, R. A. (2000). Inhibition of bacterial growth on ham and bologna by lysozyme, nisin and EDTA. Food Research International, 33, 83-90.

GreenFacts- Report highlights, Trends of plastic waste in the EU. http://www.greenfacts.org/highlights/2011/02/trends-of-plastic-waste-in-the-euenvironment-options-for-regulatory-initiatives/. Accessed on December 2015. 
Güçbilmez, Ç. M., Yemenicioğlu, A., \& Arslanoğlu, A. (2007). Antimicrobial and antioxidant activity of edible zein films incorporated with lysozyme, albumin proteins and disodium EDTA. Food research international, 40(1), 80-91.

Guo, M., Jin, T. Z., Wang, L., Scullen, O. J., \& Sommers, C. H. (2014). Antimicrobial films and coatings for inactivation of Listeria innocua on ready-to-eat deli turkey meat. Food Control, 40, 64-70.

Han, J. H. (2005). Introduction to active food packaging technologies. In J. H. Han (Ed.), Innovations in food packaging (pp. 80e107). London: Academic Press.

Hernández-Muñoz, P., Villalobos, R., \& Chiralt, A. (2004). Effect of thermal treatments on functional properties of edible films made from wheat gluten fractions. Food Hydrocolloids, 18(4), 647-654.

Higueras, L., López-Carballo, G., Hernández-Muñoz, P., Gavara, R., \& Rollini, M. (2013). Development of a novel antimicrobial film based on chitosan with LAE (ethyl-N $\alpha$ dodecanoyl-L-arginate) and its application to fresh chicken. International journal of food microbiology, 165(3), 339-345.

Hong, N. V., Trujillo, E., Puttemans, F., Jansens, K. J., Goderis, B., Van Puyvelde, P., ... \& Van Vuure, A. W. (2016). Developing rigid gliadin based biocomposites with high mechanical performance. Composites Part A: Applied Science and Manufacturing, 85, 76-83.

Hoover, R. (2001). Composition, molecular structure, and physicochemical properties of tuber and root starches: a review. Carbohydrate polymers, 45(3), 253-267.

Ibarra, V., Sendón, R., Rodríguez-Bernaldo de Quirós, A. (2016) Chapter 29 Antimicrobial Food Packaging Based on Biodegradable Materials. In J. BarrosVelázquez (Ed.), Antimicrobial Food Packaging (pp 363-384). Elsevier Inc. Academic Press.

Irkin, R., \& Esmer, O. K. (2015). Novel food packaging systems with natural antimicrobial agents. Journal of food science and technology, 52(10), 6095-6111.

Jagannath, J. H., Nanjappa, C., Das Gupta, D. K., \& Bawa, A. S. (2003). Mechanical and barrier properties of edible starch-protein-based films. Journal of Applied Polymer Science, 88(1), 64-71.

Jagannath, J. H., Radhika, M., Nanjappa, C., Murali, H. S., \& Bawa, A. S. (2006). Antimicrobial, mechanical, barrier, and thermal properties of starch-casein based, neem (Melia azardirachta) extract containing film. Journal of applied polymer science, 101(6), 3948-3954.

Janjarasskul, T., \& Krochta, J. M. (2010). Edible packaging materials. Annual Review of Food Science and Technology, 1, 415-448.

Jenssen, H., \& Hancock, R. E. W. (2009). Antimicrobial properties of lactoferrin. Biochimie, 91(1), 19-29. 
Jiang, S. J., Zhang, X., Ma, Y., Tuo, Y., Qian, F., Fu, W., \& Mu, G. (2016). Characterization of whey protein-carboxymethylated chitosan composite films with and without transglutaminase treatment. Carbohydrate Polymers, 153, 153-159.

Jiang, Z., Neetoo, H., \& Chen, H. (2011). Efficacy of freezing, frozen storage and edible antimicrobial coatings used in combination for control of Listeria monocytogenes on roasted turkey stored at chiller temperatures. Food Microbiology, 28(7), 1394-1401.

Jiménez, A., Fabra, M. J., Talens, P., \& Chiralt, A. (2012a). Edible and biodegradable starch films: a review. Food and Bioprocess Technology, 5(6), 2058-2076.

Jiménez, A., Fabra, M. J., Talens, P., \& Chiralt, A. (2012b). Effect of sodium caseinate on properties and ageing behaviour of corn starch based films. Food hydrocolloids, 29(2), 265-271.

Jiménez, A., Sánchez-González, L., Desobry, S., Chiralt, A., \& Tehrany, E. A. (2014). Influence of nanoliposomes incorporation on properties of film forming dispersions and films based on corn starch and sodium caseinate. Food Hydrocolloids, 35, 159-169.

Kamoun, E. A. (2016). N-succinyl chitosan-dialdehyde starch hybrid hydrogels for biomedical applications. Journal of advanced research, 7(1), 69-77.

Kang, J., Stasiewicz, M. J., Murray, D., Boor, K. J., Wiedmann, M., \& Bergholz, T. M. (2014). Optimization of combinations of bactericidal and bacteriostatic treatments to control Listeria monocytogenes on cold-smoked salmon. International journal of food microbiology, 179, 1-9.

Kashiri, M., Cerisuelo, J. P., Domínguez, I., López-Carballo, G., Hernández-Muñoz, P., \& Gavara, R. (2016). Novel antimicrobial zein film for controlled release of lauroyl arginate (LAE). Food Hydrocolloids, 61, 547-554.

Kechichian, V., Ditchfield, C., Veiga-Santos, P., \& Tadini, C. C. (2010). Natural antimicrobial ingredients incorporated in biodegradable films based on cassava starch. LWT-Food Science and Technology, 43(7), 1088-1094.

Kester, J. J., \& Fennema, O. R. (1986). Edible films and coatings: a review. Food technology (USA).

Kim, S., Nimni, M. E., Yang, Z., \& Han, B. (2005). Chitosan/gelatin-based films crosslinked by proanthocyanidin. Journal of Biomedical Materials Research Part B: Applied Biomaterials, 75(2), 442-450.

Krochta, J. M., \& Mulder-Johnston, D. E. (1997). Edible and biodegradable polymer films: challenges and opportunities. Food technology (USA).

Kumar, M. N. R. (2000). A review of chitin and chitosan applications. Reactive and functional polymers, 46(1), 1-27.

Kunte, L. A., Gennadios, A., Cuppett, S. L., Hanna, M. A., \& Weller, C. L. (1997). Cast films from soy protein isolates and fractions 1. Cereal Chemistry, 74(2), 115-118. 
Kuorwel, K. K., Cran, M. J., Sonneveld, K., Miltz, J., \& Bigger, S. W. (2013). Migration of antimicrobial agents from starch-based films into a food simulant. LWT-Food Science and Technology, 50(2), 432-438.

Li, X., Ji, N., Qiu, C., Xia, M., Xiong, L., \& Sun, Q. (2015). The effect of peanut protein nanoparticles on characteristics of protein-and starch-based nanocomposite films: A comparative study. Industrial Crops and Products, 77, 565-574.

Li, Y., Zhang, Z., van Leeuwen, H. P., Cohen, S., Martien, A., \& Norde, W. (2011).Uptake and release kinetics of lysozyme in and from an oxidized starch polymer microgel. Soft Matter, 7(21), 10377-10385.

Liceaga-Gesualdo, A., Li-Chan, E. C. Y., \& Skura, B. J. (2001). Antimicrobial effect of lactoferrin digest on spores of a Penicillium sp. isolated from bottled water. Food research international, 34(6), 501-506.

Liu, Z. (2005). Edible films and coatings from starch. In J. H. Han (Ed.), Innovations in food packaging (pp. 318-332). London: Elsevier Academic Press.

Liu, H., Xie, F., Yu, L., Chen, L., \& Li, L. (2009). Thermal processing of starch-based polymers. Progress in Polymer Science, 34(12), 1348-1368.

López-Rubio, A., Gavara, R., \& Lagarón, J. M. (2006). Unexpected partial crystallization of an amorphous polyamide as induced by combined temperature and humidity. Journal of applied polymer science, 102(2), 1516-1523.

Luchansky, J. B., Call, J. E., Hristova, B., Rumery, L., Yoder, L., \& Oser, A. (2005). Viability of Listeria monocytogenes on commercially-prepared hams surface treated with acidic calcium sulfate and lauric arginate and stored at 4C. Meat Science, 71(1), 92-99.

Ma, Q., Davidson, P. M., \& Zhong, Q. (2013). Antimicrobial properties of lauric arginate alone or in combination with essential oils in tryptic soy broth and $2 \%$ reduced fat milk. International journal of food microbiology, 166(1), 77-84.

Ma, Q., Zhang, Y., \& Zhong, Q. (2016). Physical and antimicrobial properties of chitosan films incorporated with lauric arginate, cinnamon oil, and ethylenediaminetetraacetate. LWT-Food Science and Technology, 65, 173-179.

Maizura, M., Fazilah, A., Norziah, M. H., \& Karim, A. A. (2007). Antibacterial activity and mechanical properties of partially hydrolyzed sago starch-alginate edible film containing lemongrass oil. Journal of Food Science, 72(6), C324-C330.

Majeed, K., Jawaid, M., Hassan, A., Bakar, A. A., Khalil, H. A., Salema, A. A., \& Inuwa, I. (2013). Potential materials for food packaging from nanoclay/natural fibres filled hybrid composites. Materials \& Design, 46, 391-410.

Malathi, A. N., Santhosh, K. S., \& Nidoni, U. (2014). Recent trends of biodegradable polymer: biodegradable films for food packaging and application of nanotechnology in biodegradable food packaging. Current Trends in Technology and Science, 3(2), 73-79. 
Mali, S., Grossmann, M. V. E., García, M. A., Martino, M. N., \& Zaritzky, N. E. (2006). Effects of controlled storage on thermal, mechanical and barrier properties of plasticized films from different starch sources. Journal of Food Engineering, 75(4), 453-460.

Malmström, E., \& Carlmark, A. (2012). Controlled grafting of cellulose fibres-an outlook beyond paper and cardboard. Polymer Chemistry, 3(7), 1702-1713.

Marcos, B., Sárraga, C., Castellari, M., Kappen, F., Schennink, G., \& Arnau, J. (2014). Development of biodegradable films with antioxidant properties based on polyesters containing a-tocopherol and olive leaf extract for food packaging applications. Food Packaging and Shelf Life, 1(2), 140-150.

Marsh, K., \& Bugusu, B. (2007). Food packaging—roles, materials, and environmental issues. Journal of food science, 72(3), R39-R55.

Martin, E. M., O’Bryan, C. A., Lary, R. Y., Griffis, C. L., Vaughn, K. L., Marcy, J. A., ... \& Crandall, P. G. (2010). Spray application of liquid smoke to reduce or eliminate Listeria monocytogenes surface inoculated on frankfurters. Meat science, 85(4), 640-644.

Martucci, J. F., \& Ruseckaite, R. A. (2009). Tensile properties, barrier properties, and biodegradation in soil of compression-Molded gelatin-dialdehyde starch films. Journal of Applied Polymer Science, 112(4), 2166-2178.

Masina, N., Choonara, Y. E., Kumar, P., du Toit, L. C., Govender, M., Indermun, S., \& Pillay, V. (2016). A review of the chemical modification techniques of starch. Carbohydrate Polymers.

McHugh, T. H., Weller, C. L., \& Krochta, J. M. (1994). Edible coatings and films based on proteins. Edible coatings and films to improve food quality, 201.

McHugh, T. H., \& Krochta, J. M. (1994). Milk-protein-based edible films and coatings. Food technology, 48(1), 97-103.

Mendes, J. F., Paschoalin, R. T., Carmona, V. B., Neto, A. R. S., Marques, A. C. P., Marconcini, J. M., Mattoso, LHC., Medeiros, E.T. \& Oliveira, J. E. (2016). Biodegradable polymer blends based on corn starch and thermoplastic chitosan processed by extrusion. Carbohydrate polymers, 137, 452-458.

Mihindukulasuriya, S. D. F., \& Lim, L. T. (2014). Nanotechnology development in food packaging: A review. Trends in Food Science \& Technology, 40(2), 149-167.

Min, S., \& Krochta, J. M. (2005). Inhibition of Penicillium commune by Edible Whey Protein Films Incorporating Lactoferrin, Lacto-ferrin Hydrolysate, and Lactoperoxidase Systems. Journal of Food Science, 70(2).

Mohajer, S., Rezaei, M., \& Hosseini, S. F. (2017). Physico-chemical and microstructural properties of fish gelatin/agar bio-based blend films. Carbohydrate Polymers, 157, 784793.

Monedero, F. M., Fabra, M. J., Talens, P., \& Chiralt, A. (2009). Effect of oleic acidbeeswax mixtures on mechanical, optical and water barrier properties of soy protein isolate based films. Journal of Food Engineering, 91(4), 509-515. 
Monedero, F. M., Hambleton, A., Talens, P., Debeaufort, F., Chiralt, A., \& Voilley, A. (2010). Study of the retention and release of $n$-hexanal incorporated into soy protein isolate-lipid composite films. Journal of food engineering, 100(1), 133-138.

Muller, J., Jiménez, A., González-Martínez, C., \& Chiralt, A. (2016). Influence of plasticizers on thermal properties and crystallization behaviour of poly (lactic acid) films obtained by compression moulding. Polymer International.

Muriel-Galet, V., López-Carballo, G., Gavara, R., \& Hernández-Muñoz, P. (2012). Antimicrobial food packaging film based on the release of LAE from EVOH. International Journal of Food Microbiology, 157(2), 239-244.

Muriel-Galet, V., López-Carballo, G., Hernández-Muñoz, P., \& Gavara, R. (2014). Characterization of ethylene-vinyl alcohol copolymer containing lauril arginate (LAE) as material for active antimicrobial food packaging. Food packaging and shelf life, 1(1), 1018.

Muriel-Galet, V., Lopez-Carballo, G., Gavara, R., \& Hernández-Muñoz, P. (2015). Antimicrobial effectiveness of lauroyl arginate incorporated into ethylene vinyl alcohol copolymers to extend the shelf-life of chicken stock and surimi sticks. Food and bioprocess technology, 8(1), 208-217.

Nair, D. V., Nannapaneni, R., Kiess, A., Mahmoud, B., \& Sharma, C. S. (2014). Antimicrobial efficacy of lauric arginate against Campylobacter jejuni and spoilage organisms on chicken breast fillets. Poultry science, 93(10), 2636-2640.

Nam, S., Scanlon, M. G., Han, J. H., \& Izydorczyk, M. S. (2007). Extrusion of pea starch containing lysozyme and determination of antimicrobial activity. Journal of food science, 72(9), E477-E484.

Newman, D., Bello, A., \& Laredo, E. (2015). Moisture effects on dielectric relaxations of poly ( $\varepsilon$-caprolactone)/starch biodegradable blends: Local, interfacial and segmental. Carbohydrate polymers, 131, 15-22.

Ortega-Toro, R., Jiménez, A., Talens, P., \& Chiralt, A. (2014). Effect of the incorporation of surfactants on the physical properties of corn starch films. Food Hydrocolloids, 38, 6675.

Ortega-Toro, R., Muñoz, A., Talens, P., \& Chiralt, A. (2016). Improvement of properties of glycerol plasticized starch films by blending with a low ratio of polycaprolactone and/or polyethylene glycol. Food Hydrocolloids, 56, 9-19.

Otero, V., Becerril, R., Santos, J. A., Rodríguez-Calleja, J. M., Nerín, C., \& GarcíaLópez, M. L. (2014). Evaluation of two antimicrobial packaging films against Escherichia coli O157: H7 strains in vitro and during storage of a Spanish ripened sheep cheese (Zamorano). Food Control, 42, 296-302.

Padrão, J., Gonçalves, S., Silva, J. P., Sencadas, V., Lanceros-Méndez, S., Pinheiro, A. C., ... \& Dourado, F. (2016). Bacterial cellulose-lactoferrin as an antimicrobial edible packaging. Food Hydrocolloids, 58, 126-140. 
Pan, Y., Shiell, B., Wan, J., Coventry, M. J., Roginski, H., Lee, A., et al. (2007). The molecular characterisation and antimicrobial activity of amidated bovine lactoferrin. International Dairy Journal, 17(6), 606-616.

Para, A., \& Konieczna-Molenda, A. (2010). Starch dialdehyde from potato starch illuminated with linearly polarized visible light. Carbohydrate polymers, 79(2), 445-448.

Park, J. W., Whiteside, W. S., \& Cho, S. Y. (2008). Mechanical and water vapor barrier properties of extruded and heat-pressed gelatin films. LWT-Food Science and Technology, 41(4), 692-700.

Park, S. I., Daeschel, M. A., \& Zhao, Y. (2004). Functional properties of antimicrobial lysozyme-chitosan composite films. Journal of Food Science, 69(8), M215-M221.

Parris, N., Dickey, L. C., Kurantz, M. J., Moten, R. O., \& Craig, J. C. (1997). Water vapor permeability and solubility of zein/starch hydrophilic films prepared from dry milled corn extract. Journal of food engineering, 32(2), 199-207.

Pattanayaiying, R., Aran, H., \& Cutter, C. N. (2014). Effect of lauric arginate, nisin Z, and a combination against several food-related bacteria. International journal of food microbiology, 188, 135-146.

Pattanayaiying, R., Aran, H., \& Cutter, C. N. (2015). Incorporation of nisin Z and lauric arginate into pullulan films to inhibit foodborne pathogens associated with fresh and ready-to-eat muscle foods. International journal of food microbiology, 207, 77-82.

Peelman, N., Ragaert, P., De Meulenaer, B., Adons, D., Peeters, R., Cardon, L., ... \& Devlieghere, F. (2013). Application of bioplastics for food packaging. Trends in Food Science \& Technology, 32(2), 128-141.

Perdones, A., Sánchez-González, L., Chiralt, A., \& Vargas, M. (2012). Effect of chitosan-lemon essential oil coatings on storage-keeping quality of strawberry. Postharvest Biology and Technology, 70, 32-41.

Petersen, K., Nielsen, P. V., Bertelsen, G., Lawther, M., Olsen, M. B., Nilsson, N. H., \& Mortensen, G. (1999). Potential of biobased materials for food packaging. Trends in Food Science \& Technology, 10(2), 52-68.

Pereda, M., Ponce, A. G., Marcovich, N. E., Ruseckaite, R. A., \& Martucci, J. F. (2011). Chitosan-gelatin composites and bi-layer films with potential antimicrobial activity. Food Hydrocolloids, 25(5), 1372-1381.

Pérez-Gago, M. B., Nadaud, P., \& Krochta, J. M. (1999). Water vapor permeability, solubility, and tensile properties of heat-denatured versus native whey protein films. Journal of Food Science, 64(6), 1034-1037.

Pezo, D., Navascues, B., Salafranca, J., \& Nerin, C. (2012). Analytical procedure for the determination of ethyl lauroyl arginate (LAE) to assess the kinetics and specific migration from a new antimicrobial active food packaging. Analytica Chimica Acta, 745, 92-98. 
Plastic Europe-Association of plastics manufacturers, Plastics, the facts 2015. http://www.plasticseurope.org/documents/document/20151216062602-

plastics_the_facts_2015_final_30pages_14122015.pdf. Accessed on November, 2016.

Porto-Fett, A. C. S., Campano, S. G., Smith, J. L., Oser, A., Shoyer, B., Call, J. E., \& Luchansky, J. B. (2010). Control of Listeriamonocytogenes on commercially-produced frankfurters prepared with and without potassium lactate and sodium diacetate and surface treated with lauric arginate using the Sprayed Lethality in Container (SLIC®) delivery method. Meat science, 85(2), 312-318.

Quintavalla, S., \& Vicini, L. (2002). Antimicrobial food packaging in meat industry. Meat science, 62(3), 373-380.

Quintieri, L., Pistillo, B. R., Caputo, L., Favia, P., \& Baruzzi, F. (2013). Bovine lactoferrin and lactoferricin on plasma-deposited coating against spoilage Pseudomonas spp. Innovative Food Science \& Emerging Technologies, 20, 215-222.

Rasal, R. M., \& Hirt, D. E. (2009). Toughness decrease of PLA-PHBHHx blend films upon surface-confined photopolymerization. Journal of Biomedical Materials Research Part A, 88(4), 1079-1086.

Raybaudi-Massilia, R., Mosqueda-Melgar, J., Soliva-Fortunyt, R., Martín-Belloso O. (2016) Chapter 52 - Combinational Edible Antimicrobial Films and Coatings. In J. Barros-Velázquez (Ed.), Antimicrobial Food Packaging (pp 363-384). Elsevier Inc. Academic Press.

Reddy, M. M., Vivekanandhan, S., Misra, M., Bhatia, S. K., \& Mohanty, A. K. (2013). Biobased plastics and bionanocomposites: Current status and future opportunities. Progress in Polymer Science, 38(10), 1653-1689.

Requena, R., Jiménez, A., Vargas, M., \& Chiralt, A. (2016b). Effect of plasticizers on thermal and physical properties of compression-moulded poly [(3-hydroxybutyrate)-co(3-hydroxyvalerate)] films. Polymer Testing, 56, 45-53.

Requena, R., Jiménez, A., Vargas, M., \& Chiralt, A. (2016a). Poly [(3-hydroxybutyrate)co-(3-hydroxyvalerate)] active bilayer films obtained by compression moulding and applying essential oils at the interface. Polymer International.

Reyes, R. E., Manjarrez, H. A., \& Drago, M. E. (2005). El hierro y la virulencia bacteriana. Enfermedades Infecciosas y Microbiología, 25, 104-107.

Rhim, J. W., Gennadios, A., Weller, C. L., Cezeirat, C., \& Hanna, M. A. (1998). Soy protein isolate-dialdehyde starch films. Industrial Crops and Products, 8(3), 195-203.

Rhim, J. W., Park, H. M., \& Ha, C. S. (2013). Bio-nanocomposites for food packaging applications. Progress in Polymer Science, 38(10), 1629-1652.

Robertson, G. L. (2016). Food packaging: principles and practice. CRC press.

Rocca-Smith, J. R., Marcuzzo, E., Karbowiak, T., Centa, J., Giacometti, M., Scapin, F., Venir, E., Sensidoni, A., \& Debeaufort, F. (2016). Effect of lipid incorporation on 
functional properties of wheat gluten based edible films. Journal of Cereal Science, 69, 275-282.

Rodriguez, E., Seguer, J., Rocabayera, X., \& Manresa, A. (2004). Cellular effects of monohydrochloride of I-arginine, Na-lauroyl ethylester (LAE) on exposure to Salmonella typhimurium and Staphylococcus aureus. Journal of Applied Microbiology, 96(5), 903912.

Rubilar, J. F., Candia, D., Cobos, A., Díaz, O., \& Pedreschi, F. (2016). Effect of nanoclay and ethyl-Na-dodecanoyl-l-arginate hydrochloride (LAE) on physico-mechanical properties of chitosan films. LWT-Food Science and Technology, 72, 206-214.

Sahraee, S., Milani, J. M., Ghanbarzadeh, B., \& Hamishehkar, H. (2017). Effect of corn oil on physical, thermal, and antifungal properties of gelatin-based nanocomposite films containing nano chitin. LWT-Food Science and Technology, 76, 33-39.

Sánchez-García, M.D., Giménez, E., Lagaron, J.M., (2008). Morphology and barrier properties of solvent cast composites of thermoplastic biopolymers and purified cellulose fibers. Carbohydrate. Polymers. 71, 235-244.

Sánchez-González, L., Arab-Tehrany, E., Cháfer, M., González-Martínez, C., \& Chiralt, A. (2015). Active Edible and Biodegradable Starch Films. Polysaccharides: Bioactivity and Biotechnology, 717-734.

Semenova, Maria (2016). Protein- polysaccharide associative interactions in the design of tailor-made colloidal particles, Current Opinion in Colloid \& Interface Science.

Shih, I. L., Shen, M. H., \& Van, Y. T. (2006). Microbial synthesis of poly(e-lysine) and its various applications. Bioresource Technology, 97, 1148-1159.

Singh, J., Kaur, L., \& McCarthy, O. J. (2007). Factors influencing the physico-chemical, morphological, thermal and rheological properties of some chemically modified starches for food applications-A review. Food Hydrocolloids, 21(1), 1-22.

Siracusa, V., Rocculi, P., Romani, S., \& Dalla Rosa, M. (2008). Biodegradable polymers for food packaging: a review. Trends in Food Science \& Technology, 19(12), 634-643.

Smith, A. M. (2001). The biosynthesis of starch granules. Biomacromolecules, 2(2), 335341.

Soares, R. M., \& Soldi, V. (2010). The influence of different cross-linking reactions and glycerol addition on thermal and mechanical properties of biodegradable gliadin-based film. Materials Science and Engineering: C, 30(5), 691-698.

Soliman, A. A., El-Shinnawy, N. A., \& Mobarak, F. (1997). Thermal behaviour of starch and oxidized starch. Thermochimica Acta, 296(1), 149-153.

Soliman, E. A., \& Furuta, M. (2014). Influence of Phase Behavior and Miscibility on Mechanical, Thermal and Micro-Structure of Soluble Starch-Gelatin Thermoplastic Biodegradable Blend Films. Food and Nutrition Sciences, 2014. 
Song, L., Sang, Y. J., Cai, L. M., Shi, Y. C., Farrah, S. R., \& Baney, R. H. (2010). The effect of cooking on the antibacterial activity of the dialdehyde starch suspensions. Starch/Stärke, 62, 458-466.

Soni, K. A., Desai, M., Oladunjoye, A., Skrobot, F., \& Nannapaneni, R. (2012). Reduction of Listeria monocytogenes in queso fresco cheese by a combination of listericidal and listeriostatic GRAS antimicrobials. International journal of food microbiology, 155(1), 8288.

Spence, K. E., Jane, J. L., \& Pometto Jr, A. L. (1995). Dialdehyde starch and zein plastic: mechanical properties and biodegradability. Journal of environmental polymer degradation, 3(2), 69-74.

Stopforth, J. D., Visser, D., Zumbrink, R., Van Dijk, L., \& Bontenbal, E. W. (2010). Control of Listeria monocytogenes on cooked cured ham by formulation with a lactatediacetate blend and surface treatment with lauric arginate. Journal of food protection, 73(3), 552-555.

Sun, Q., Sun, C., \& Xiong, L. (2013). Mechanical, barrier and morphological properties of pea starch and peanut protein isolate blend films. Carbohydrate polymers, 98(1), 630637.

Sung, S. Y., Sin, L. T., Tee, T. T., Bee, S. T., Rahmat, A. R., Rahman, W. A. W. A., Tan, A-C \& Vikhraman, M. (2013). Antimicrobial agents for food packaging applications. Trends in Food Science \& Technology, 33(2), 110-123.

Terjung, N., Loeffler, M., Gibis, M., Hinrichs, J., \& Weiss, J. (2014). Control of listeria in meat emulsions by combinations of antimicrobials of different solubilities. Food research international, 66, 289-296.

Tharanathan, R. N. (2005). Starch—value addition by modification. Critical reviews in food science and nutrition, 45(5), 371-384.

Theinsathid, P., Visessanguan, W., Kruenate, J., Kingcha, Y., \& Keeratipibul, S. (2012). Antimicrobial Activity of Lauric Arginate-Coated Polylactic Acid Films against Listeria monocytogenes and Salmonella Typhimurium on Cooked Sliced Ham. Journal of Food Science, 77(2), M142-M149.

Talón, E., Trifkovic, K. T., Nedovic, V. A., Bugarski, B. M., Vargas, M., Chiralt, A., \& González-Martínez, C. (2016). Antioxidant edible films based on chitosan and starch containing polyphenols from thyme extracts. Carbohydrate Polymers.

Van Soest, J. J. G., \& Borger, D. B. (1997). Structure and properties of compressionmolded thermoplastic starch materials from normal and high-amylose maize starches. Journal of applied polymer science, 64(4), 631-644.

Vert, M., Hellwich, K. H., Hess, M., Hodge, P., Kubisa, P., Rinaudo, M., \& Schué, F. (2012). Terminology for biorelated polymers and applications (IUPAC Recommendations 2012). Pure and Applied Chemistry, 84(2), 377-410. 
Wang, W., Wang, K., Xiao, J., Liu, Y., Zhao, Y., \& Liu, A. (2017). Performance of high amylose starch-composited gelatin films influenced by gelatinization and concentration. International Journal of Biological Macromolecules, 94, 258-265.

Wang, Y., Zhang, Y., Hou, C., Qi, Z., He, X., \& Li, Y. (2015). Facile synthesis of monodisperse functional magnetic dialdehyde starch nano-composite and used for highly effective recovery of $\mathrm{Hg}$ (II). Chemosphere, 141, 26-33.

Wihodo, M., \& Moraru, C. I. (2013). Physical and chemical methods used to enhance the structure and mechanical properties of protein films: A review. Journal of Food Engineering, 114(3), 292-302.

Wong, P. Y. Y., \& Kitts, D. D. (2003). Chemistry of buttermilk solid antioxidant activity. Journal of dairy science, 86(5), 1541-1547.

Wu, Y., Rhim, J. W., Weller, C. L., Hamouz, F., Cuppett, S., \& Schnepf, M. (2000). Moisture loss and lipid oxidation for precooked beef patties stored in edible coatings and films. Journal of food science, 65(2), 300-304.

Xie, F., Pollet, E., Halley, P. J., \& Avérous, L. (2013). Starch-based nano-biocomposites. Progress in Polymer Science, 38(10), 1590-1628.

Yu, J., Chang, P. R., \& Ma, X. (2010). The preparation and properties of dialdehyde starch and thermoplastic dialdehyde starch. Carbohydrate Polymers, 79(2), 296-300.

Yu, D. M., Xiao, S. Y., Tong, C. Y., Chen, L., \& Liu, X. M. (2007). Dialdehyde starch nanoparticles: Preparation and application in drug carrier. Chinese Science Bulletin, 52, 2913-2918.

Zhang, L., Liu, P., Wang, Y., \& Gao, W. (2011). Study on physico-chemical properties of dialdehyde yam starch with different aldehyde group contents. Thermochimica Acta, 512(1-2), 196-201.

Zhang, L., Zhang, S., Dong, F., Cai, W., Shan, J., Zhang, X., \& Man, S. (2014a). Antioxidant activity and in vitro digestibility of dialdehyde starches as influenced by their physical and structural properties. Food chemistry, 149, 296-301.

Zhang, L., Li, R., Dong, F., Tian, A., Li, Z., \& Dai, Y. (2015). Physical, mechanical and antimicrobial properties of starch films incorporated with $\varepsilon$-poly-I-lysine. Food chemistry, 166, 107-114.

Zhang, N., Liu, X., Yu, L., Shanks, R., Petinaks, E., \& Liu, H. (2013). Phase composition and interface of starch-gelatin blends studied by synchrotron FTIR micro-spectroscopy. Carbohydrate polymers, 95(2), 649-653.

Zhang, S. D., Zhang, Y. R., Zhu, J., Wang, X. L., Yang, K. K., \& Wang, Y. Z. (2007). Modified corn starches with improved comprehensive properties for preparing thermoplastics. Starch-Stärke, 59(6), 258-268.

Zhang, Y., Wang, X., Zhao, G., \& Wang, Y. (2012). Preparation and properties of oxidized starch with high degree of oxidation. Carbohydrate Polymers, 87(4),2554-2562 
Zhang, Y., Rempel, C., \& McLaren, D. (2014b). Chapter 16 - Thermoplastic starch. In J. H. Han (Ed.), Innovations in food packaging (2nd ed., pp. 391-412). San Diego: Academic Press.

Zubeldía, F., Ansorena, M. R., \& Marcovich, N. E. (2015). Wheat gluten films obtained by compression molding. Polymer Testing, 43, 68-77. 


\section{OBJECTIVES}

he main objective of the present doctoral thesis is to develop both starch and protein-based active and biodegradable films for packaging applications; these have antibacterial and/or antioxidant properties and are obtained by both wet (extension and drying) and dry (melt blending and compression moulding) methods. The films will be characterized as to their functional properties as a packaging material, as well as to their antimicrobial and antioxidant ability for food preservation.

\section{Specific objectives}

The specific objectives of the thesis are to improve the functional properties of the starch films, while conferring antimicrobial or antioxidant properties on them, by the incorporation or blending of different protein materials. In this sense, different approaches have been considered:

O1 The blending of corn starch and buttermilk, as a potentially active component, in films obtained by casting.

O2 The incorporation of lysozyme and lactoferrin into potato starch films obtained by casting.

03 The blending of corn starch and bovine gelatin with the incorporation of lysozyme and LAE as antimicrobial compounds, in films obtained by both casting and melt blending-compression moulding.

O4 The oxidation of corn starch for the purposes of obtaining oxidized starch - bovine gelatin blend films by casting, incorporating LAE as an antimicrobial compound.

O5 The application of the active films containing LAE on real foods: marinated salmon and chicken breast fillets. 


\section{CHAPTERS}

CHAPTER 1 Physical and bioactive properties of corn starch buttermilk edible films

CHAPTER 2 Effect of the incorporation of antimicrobial/antioxidant proteins on the properties of potato starch films

CHAPTER 3 Influence of the processing method and antimicrobial agents on properties of starch-gelatin biodegradable films

CHAPTER 4 Influence of starch oxidation on the functionality of starch-gelatin based active films

CHAPTER 5 Application of the active films containing LAE on real foods: marinated salmon and chicken breast fillets

Active starch-gelatin films for shelf-life extension of marinated salmon

Bioactive packaging with LAE to prolong the shelf life of chicken breasts fillets 


\section{CHAPTER 1}

\section{PHYSICAL AND BIOACTIVE PROPERTIES OF CORN STARCH - BUTTERMILK EDIBLE FILMS}

Olga Moreno*, Clara Pastor, Justine Muller, Lorena Atarés, Chelo González, Amparo Chiralt.

Departamento de Tecnología de Alimentos - Instituto de Ingeniería de Alimentos para el Desarrollo. Universitat Politècnica de València, Camino de Vera s/n 46022 Valencia, Spain

Journal of Food Engineering 141 (2014) 27-36 


\title{
ABSTRACT
}

\begin{abstract}
he effect of incorporating different ratios of both non-heated and heated $\left(95^{\circ} \mathrm{C}\right)$ buttermilk (BM) to corn starch (CS) films was analyzed in terms of its structural, mechanical, barrier, optical and bioactive properties. The properties of the film forming dispersions (particle size distribution, $\zeta$-potential and rheological behavior) were also analyzed. As the BM increased in the blend, both the average particle size and the apparent viscosity of the film forming dispersions were reduced. The low degree of compatibility between both materials resulted in heterogeneous structures, where an interpenetrated protein phase in the starch matrix was observed as a result of the protein gelation when BM was heated. This affected the mechanical and barrier properties giving rise to more resistant and extensible, and less permeable films than in non-heated BM. Only films formulated with heated BM exhibited antioxidant activity, probably due to the release of the antioxidant peptides during thermal treatment of proteins. BM did not have any effect on the growth of Listeria innocua.
\end{abstract}

KEYWORDS: edible films, corn starch, buttermilk, heat treatment. 


\section{INTRODUCTION}

urrently, most of the plastics used are petroleum-derived (Saiah et al., 2009) and about a third of the world's plastic production goes into packaging applications (Wiles, 2005). The use of these non-biodegradable materials represents a huge worldwide environmental problem (Azeredo, 2009), since these materials are highly polluting and their recycling implies a great expense (SánchezGarcía et al., 2008). To face up to this situation, much research work has been focused on the substitution of synthetic plastics by biodegradable polymers (biopolymers) obtained from renewable resources (Saiah et al., 2009), the use of which would reduce the environmental impact of petroleum plastics (Sánchez-García et al., 2008).

Of the renewable sources with film-forming ability, polysaccharides are the most abundant (Carvalho, 2008). Starch is often used due to its low cost and easy availability (Cuq et al., 1997, Carvalho, 2008). Native starch becomes thermoplastic after heat treatment with plasticizers, with properties similar to those of common synthetic polymers. The material obtained is called thermoplastic starch (TPS).

The development of biodegradable packaging materials with adequate physical properties (mechanical and water and gas barrier), with antimicrobial or antioxidant activity, is especially relevant for food preservation. This stems both from reasons related to environmental aspects and from consumer demand for safe and high quality products. The incorporation of active compounds into food packaging increases the efficiency of food preservation. Packaging becomes the vehicle for preservatives or compounds of interest from a nutritional point of view, such as nutraceuticals.

Several authors have developed and characterized edible films based on starch of different origins containing diverse bioactive ingredients (Pyla et al., 2010; Kechichian et al., 2010; Shen et al., 2010; Mathew \& Abraham, 2008). Buttermilk is a by-product of the butter-making process, which is spray-dried to obtain a commercial powder, whose principal compounds are lactose, proteins, fat and mineral salts. The breaking of the fat globule membrane during the process releases a high quantity of proteins and membrane peptides with bioactive properties, such as antioxidants and others with physiological effects (Affolter et al. 2010; Michalski \& Januel, 2006). Previous studies have pointed out the antioxidant role of buttermilk, (Wong \& Kitts, 2001, 2003), and of 
different dairy peptides (Pihlanto, 2006). Both lactoferrin and its derived peptide lactoferricin have been reported to have bactericidal, fungicidal, and antiviral activities (Van der Kraan et al, 2004). The heat treatment of buttermilk leads to the inactivation of its native flora and could release antimicrobial peptides from milk proteins (Mills et al, 2011).

No previous studies have been found into the use of buttermilk to form films, despite their bioactive properties and high protein content (whey protein) with film-forming ability. The other compounds, lactose and minerals, would act as plasticizers which can reduce the requirements of other agents to this end. Likewise, the blend of buttermilk with other film-forming compounds, such as starch, might improve the functional properties of the film and its bioactivity.

The objective of this work was to analyse the effect of buttermilk incorporation on the properties of the film-forming dispersions and the physical (mechanical, barrier, optical) and microstructural characteristics of corn starch films. The impact that heat treatment has on films containing buttermilk was analyzed. The antioxidant and antimicrobial activities of the films were also tested.

\section{MATERIALS AND METHODS}

\subsection{Raw materials}

Corn starch (CS) and buttermilk (BM), supplied respectively by Roquette Laisa España, SA (Valencia, Spain) and Lactotecnia, S.L. (Barcelona, Spain), were used to obtain the films. BM composition was: lactose $(51 \%)$, proteins $(31 \%)$, fat $(7 \%)$ and salts $(7 \%)$. Glycerol and magnesium nitrate were purchased from Panreac Química S.L.U. (Barcelona, Spain). The reactants for the antioxidant capacity assay - Trolox (6-hydroxy2,5,7,8-tetramethylchroman-2-carboxylic acid), $\mathrm{K}_{2} \mathrm{~S}_{2} \mathrm{O}_{8}$ and ABTS (202-azino-bis-[3etilbenzotiazol-6-sulfonic acid]) - were supplied by Sigma-Aldrich (Madrid, Spain). For the antimicrobial activity analysis, stock culture of Listeria innocua (CECT 910) was supplied by the Spanish Type Culture Collection (CECT, Burjassot, Spain). Tryptone Soy 
Broth, Agar bacteriological and tryptone phosphatewater were provided by Scharlab, (Barcelona, Spain). NaCl was purchased from (Panreac, Barcelona, Spain).

\subsection{Preparation of film forming dispersions (FFD)}

CS was dispersed at $3 \%(\mathrm{w} / \mathrm{w})$ in distilled water and stirred for 5 min at room temperature. Then the dispersion was heated at $95{ }^{\circ} \mathrm{C}$ for $30 \mathrm{~min}$ to induce starch gelatinization and cooled down under running water to reach room temperature. Glycerol was added as a plasticizer in a CS:glycerol ratio of 1:0.25 (Jiménez et al., 2012, Talja et al., 2007, Teixeira et al., 2007). Distilled water was added to adjust the concentration, and homogenization was carried out in a rotor-stator ultraturrax (DI25, Janke and Kunkel, Germany) at 13,500 rpm for 4 min. CS dispersion was degasified for $15 \mathrm{~min}$ at room temperature by means of a vacuum pump (MZ 2C NT, Vacuubrand GMBH + CO KG, Wertheim, Germany). BM (3\% w/w) was dispersed in distilled water and stirred for 5 min at room temperature. Glycerol was added in a BM:glycerol ratio of 1:0.25, and the dispersion was stirred at room temperature for another $10 \mathrm{~min}$. Finally, both suspensions were mixed in four different CS:BM w/w ratios $(1: 0,0.75: 0.25,0.50: 0.50,0.40: 0.60)$ and kept under stirring at room temperature for $10 \mathrm{~min}$.

A second series of FFDs was prepared with the aim of testing the effect that heat treatment had on buttermilk. In this case, both dispersions were mixed prior to heating them for $30 \mathrm{~min}$ at $95^{\circ} \mathrm{C}$. The resulting formulations were referred to as $\mathrm{CS}_{0.75}: \mathrm{BM}_{0.25} \mathrm{Q}$, $\mathrm{CS}_{0.50}: \mathrm{BM}_{0.50} \mathrm{Q}$ and $\mathrm{CS}_{0.40}: \mathrm{BM}_{0.60} \mathrm{Q}$.

\subsection{Characterization of the film-forming dispersions}

\subsubsection{Particle size, $\mathrm{pH}$ and $\zeta$-potential}

The particle size analysis of the FFDs was carried out by using a laser scattering instrument (MasterSizer 2000, Malvern Instruments,UK). The samples were dispersed in distilled water at 2,000 rpm until an obscuration rate of 8-10\% was obtained. The Mie theory was applied by considering a refractive index of 1.52 and absorption of 0.1 . Three samples of each FFD were measured at $25^{\circ} \mathrm{C}$. Two average diameters were obtained: the area-volume mean diameter $\left(d_{32}\right)$, which is related to the average surface area of droplets exposed to the continuous phase per unit volume of emulsion, and the volume- 
length diameter $\left(d_{43}\right)$, which is the sum of the volume ratio of droplets in each size-class multiplied by the mid-point diameter of the size-class.

$$
\begin{aligned}
& \mathrm{d}_{3,2}=\frac{\sum \mathrm{n}_{\mathrm{i}} \mathrm{d}_{\mathrm{i}}^{3}}{\sum \mathrm{n}_{\mathrm{i}} \mathrm{d}_{\mathrm{i}}^{2}} \\
& \mathrm{~d}_{4,3}=\frac{\sum \mathrm{n}_{\mathrm{i}} \mathrm{d}_{\mathrm{i}}^{4}}{\sum \mathrm{n}_{\mathrm{i}} \mathrm{d}_{\mathrm{i}}^{3}}
\end{aligned}
$$

The $\mathrm{pH}$ of the FFDs was measured in triplicate at $25{ }^{\circ} \mathrm{C}$ by using a $\mathrm{pH}$-meter (SevenEasy, Mettler-Toledo, S.A.E, Barcelona, Spain). Prior to the measurement of Zeta

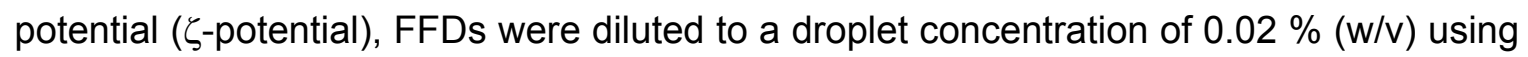
distilled water. $\zeta$-potential was determined in triplicate by measuring the electrophoretic mobility of the dispersed particles in a charged field by using ZetaSizer equipment (Nano-Z, Malvern Instruments, UK). The Smoluchowsky mathematical model was used by the software to convert the electrophoretic mobility measurements into $\zeta$-potential values.

\subsubsection{Rheological behaviour}

The rheological behaviour of the FFDs was analysed in triplicate at $25^{\circ} \mathrm{C}$ by means of a rotational rheometer (HAAKE RheoStress 1, Thermo Electric Corporation, Germany) with a type ISO 3219 Z34DIN sensor system of coaxial cylinders. Rheological curves were obtained after a stabilization time of $5 \mathrm{~min}$ at $25^{\circ} \mathrm{C}$. Shear stress $(\sigma$ in Pa) was measured as a function of shear rate $\left(\dot{\gamma}\right.$ in s $\left.{ }^{-1}\right)$ from 0 to $512 \mathrm{~s}^{-1}$ in the following way: 5 min to reach the maximum shear rate and 5 min to attain zero shear rate. The power law model (Equation 1.3) was applied to determine both the consistency index ( $\mathrm{K}$ in Pa. $\mathrm{s}^{\mathrm{n}}$ ) and the flow behaviour index $(n)$. Additionally, the apparent viscosity $\left(\eta_{a p}\right)$ at $100 \mathrm{~s}^{-1}$ was determined.

$$
\sigma=\mathrm{K} \cdot \dot{\mathrm{Y}}^{\mathrm{n}}
$$




\subsection{Film preparation}

FFDs were poured onto framed and levelled polytetrafluorethylene (PTFE) plates $(15 \mathrm{~cm}$ diameter) and were dried for at least $24 \mathrm{~h}$ under natural convection at $25^{\circ} \mathrm{C}$ and $45( \pm 2)$ $\%$ relative humidity $(\mathrm{RH})$. Film thickness was controlled by pouring the amount of FFD onto the PTFE plate that would provide a surface density of solids of $56 \mathrm{~g} / \mathrm{m}^{2}$. Dry films were peeled off the casting surface and preconditioned for 14 days in desiccators at 25 ${ }^{\circ} \mathrm{C}$ and $53 \% \mathrm{RH}$, by using an oversaturated $\mathrm{Mg}\left(\mathrm{NO}_{3}\right)_{2}$ solution.

\subsection{Film characterization}

\subsubsection{Film thickness}

A hand-held digital micrometer (Electronic Digital Micrometer, Comecta S.A., Barcelona, Spain) was used to measure film thickness to the nearest $0.0001 \mathrm{~mm}$. This was measured in triplicate for samples submitted to mechanical tests and water vapour permeability analyses.

\subsubsection{Microstructure}

Cross-section images of the films were obtained by using Scanning Electron Microscopy (SEM) with a JEOL $®$ microscope, model JSM-5410. The samples were immersed in liquid nitrogen and cryofractured. After gold coating, the samples were observed using an accelerating voltage of $10 \mathrm{kV}$.

The surface morphology of studied films, previously dried with $\mathrm{P}_{2} \mathrm{O}_{5}$, was observed by using Atomic Force Microscopy (AFM), with an 8 multimode microscope, Bruker AXS, (Santa Barbara, California), under V NanoScope ${ }^{\circledR}$ electronic control. Three $1 \times 1 \mathrm{~cm}$ square samples per formulation were cut and the surface scanning was carried out by using the tapping mode, on a 50x50 $\mu \mathrm{m}$ area and with a maximum vertical limit of $6 \mu \mathrm{m}$. According to the ASME B46.1 (1995) method, the following statistical parameters, related to the surface roughness of each sample, were calculated: 
Average roughness $\left(R_{a}\right)$ : arithmetic average of the absolute values of height deviations from a mean surface (Equation 1.4).

$$
\mathrm{R}_{\mathrm{a}}=\frac{1}{\mathrm{~N}} \sum_{\mathrm{J}=1}^{\mathrm{N}}\left|\mathrm{Z}_{\mathrm{j}}\right|
$$

Root-mean-square roughness $\left(R_{q}\right)$ : root-mean-square average of height deviations taken from the mean data plane $\left(Z_{\mathrm{j}}\right)$ (Equation 1.5).

$$
R_{\mathrm{q}}=\sqrt{\frac{\sum_{\mathrm{J}=1}^{N} Z_{J}^{2}}{N}}
$$

The percentage image surface area difference (\% ISAD) was also calculated. This parameter represents the difference between the image's three-dimensional surface area and the two-dimensional projected surface area. Surface images were also obtained by using the Phase Imaging mode, which allows surface variations of the composition, adhesion, friction, viscoelasticity and other properties to be detected.

\subsubsection{Mechanical properties}

A texture analyser (TA-XTplus, Stable Micro Systems, Surrey, United Kingdom) was used to measure the mechanical properties of films equilibrated at $53 \% \mathrm{RH}$ and $25^{\circ} \mathrm{C}$. Film strips (25.4 mm wide and $100 \mathrm{~mm}$ long) were mounted in the tensile grips (A/TG model) and stretched at a rate of $50 \mathrm{~mm} / \mathrm{min}$ until breaking. The elastic modulus (EM), tensile strength at break (TS) and percentage of elongation at break (\% E) were determined from stress-Henky strain curves, obtained from force-deformation data. The experiments were carried out at $25^{\circ} \mathrm{C}$ on twelve replicates per formulation. 


\subsubsection{Moisture content}

In order to determine the moisture content of the films, six samples of each formulation were dried at $60{ }^{\circ} \mathrm{C}$ for $24 \mathrm{~h}$ in a natural convection oven, and for another $24 \mathrm{~h}$ in a vacuum oven $\left(60^{\circ} \mathrm{C}\right)$. Afterwards, the samples were placed into desiccators with $\mathrm{P}_{2} \mathrm{O}_{5}$ at room temperature, until constant weight was reached.

\subsubsection{Water vapour permeability}

The water vapour permeability (WVP) of films was measured with a modification of the ASTM E96-95 (ASTM, 1995) gravimetric method, using Payne permeability cups (Elcometer SPRL, Hermelle/s Argenteau, Belgium) of $3.5 \mathrm{~cm}$ in diameter. For each formulation, measurements were replicated six times and WVP was calculated following the methodology described by Gennadios et al. (1994), at $25^{\circ} \mathrm{C}$ and a $53-100 \%$ relative humidity gradient, which was generated by using an oversaturated $\mathrm{Mg}\left(\mathrm{NO}_{3}\right)_{2}$ solution and pure water, respectively. To determine WVP, the cups were weighed every $2 \mathrm{~h}$, for $10 \mathrm{~h}$. After the steady state was reached, the slope obtained from the weight loss vs. time was used to calculate WVP, according to ASTM (1995).

\subsubsection{Optical properties}

The optical properties of the films were determined in film samples previously equilibrated at $25^{\circ} \mathrm{C}$ and $53 \% \mathrm{RH}$. CIE-L*a* ${ }^{*}{ }^{*}$ coordinates: lightness $\left(\mathrm{L}_{a b}{ }^{*}\right)$, chrome $\left(\mathrm{C}_{\mathrm{ab}}{ }^{*}\right)$ and hue $\left(\mathrm{h}_{\mathrm{ab}}{ }^{*}\right)$ of the films were obtained through the surface reflectance spectra determined by means of a spectrocolorimeter (CM-3600d, Minolta Co., Tokyo, Japan) with a $10-\mathrm{mm}$ diameter window, using $\mathrm{D}_{65}$ illuminant $/ 10^{\circ}$ observer. Measurements were taken on black and white backgrounds and the reflectance infinite $\left(R_{\infty}\right)$ was determined. The whiteness index (WI) was calculated using Equation 1.6:

$$
W I=100-\sqrt{(100-L *)+a *^{2}+b *^{2}}
$$


The internal transmittance $\left(T_{i}\right)$ of the films was determined by applying the KubelkaMunk theory (Hutchings, 1999) for multiple scattering to the reflection spectra, following the methodology described by Pastor et al. (2010).

The gloss was measured on the film side in contact with air during drying, at a $60^{\circ}$ incidence angle according to the ASTM standard D-523 (ASTM, 1999), using a flat surface gloss meter (Multi-Gloss 268, Minolta Co., Tokyo, Japan). Six replicates were obtained per formulation. All the results are expressed as gloss units, relative to a highly polished surface of black glass standard with a value near to 100 .

\subsubsection{Antioxidant activity}

The antioxidant capacity of BM and of the films was determined through a spectrophotometric method, as described by $\mathrm{Re}$ et al. (1999). The objective of this method is to compare the antioxidant activity of the analyzed substance with that of an antioxidant standard, trolox (6-hydroxy-2,5,7,8-tetramethylchroman-2-carboxylic acid), a vitamin $\mathrm{E}$ analogue.

ABTS (2,2'-azino-bis[3-ethylbenzothiazoline-6-sulphonic acid]) was dissolved in water to a concentration of $7 \mathrm{mM}$, and allowed to react with a $2.45 \mathrm{mM}$ potassium persulfate solution (final concentrations) for $16 \mathrm{~h}$ in the dark. ABTS radical cation $\left(\mathrm{ABTS}^{-+}\right.$), a blue chromophore, was produced during that period. The ABTS ${ }^{++}$solution was diluted with ethanol until an initial absorbance of $0.70( \pm 0.02)$ at $734 \mathrm{~nm}\left(\mathrm{~A}_{0}\right) .10 \mu \mathrm{l}$ of the test solution was added to $1 \mathrm{~mL}$ of this solution, and the percentage of absorbance reduction at 6 minutes was registered. All absorbance measurements were taken with a Beckman Coulter DU 730 spectrophotometer, using ethanol as blank. The test solutions (BM or film extracts) were prepared by completely dissolving $0.5 \mathrm{~g}$ of the BM or film in $10 \mathrm{ml}$ of bidistilled water, and stirring for $16 \mathrm{~h}$. Tests were performed in triplicate.

A calibration curve ( $\%$ absorbance reduction vs. concentration of Trolox) was obtained with different dilutions ( $0 \mathrm{mg} / \mathrm{l}$ to $50 \mathrm{mg} / \mathrm{L}$ ) of trolox as standard antioxidant agent. The Trolox equivalent antioxidant capacity (TEAC) of BM and films was defined as the concentration of BM or dry film (g BM or dry film /L) producing the same perceptual absorbance reduction as $1 \mathrm{mM}$ Trolox. 


\subsubsection{Antimicrobial activity}

The antimicrobial properties of BM were analyzed following a modification of the method described by Kristo et al. (2008). Stock culture of L.innocua (CECT was kept frozen (-18 ${ }^{\circ} \mathrm{C}$ ) in Tryptone Soy Broth (TSB) supplemented with $30 \%$ of glycerol. To regenerate the culture, a loopful was transferred into $10 \mathrm{~mL}$ of TSB, the tube was incubated at $37^{\circ} \mathrm{C}$ overnight and $10 \mu \mathrm{L}$ were again transferred into $10 \mathrm{~mL}$ of TSB. The tube was kept at 37 ${ }^{\circ} \mathrm{C}$ for $48 \mathrm{~h}$ to reach the exponential phase of growth. Finally, the culture was adequately diluted for the inoculation of the agar plates in order to obtain $10^{2} \mathrm{UFC} / \mathrm{cm}^{2}$ target inocula.

Tryptone Soy Agar - TSB with Agar bacteriological with $3 \% \mathrm{NaCl}$ - was used as a model solid food system (TSA-NaCl) (Sánchez-González et al., 2011). Under sterile conditions, $20 \mathrm{~g}$ of TSA-NaCl were poured into each Petri dish and left to solidify. The culture of Listeria innocua was properly diluted and inoculated on the surface of the culture medium. Then, a maximally concentrated solution of heated buttermilk $(10 \% \mathrm{w} / \mathrm{w})$ was homogenously poured onto the inoculated surface to provide the same surface density of $\mathrm{BM}$ as the films $\left(44.8 \mathrm{~g} / \mathrm{m}^{2}\right)$, and the plates were dried under sterile conditions for 2 hours. Inoculated and uncoated TSA-NaCl Petri dishes were used as control. Plates were then covered with parafilm to avoid dehydratation and stored at $10^{\circ} \mathrm{C}$ for 13 days. Counts were made periodically during the storage period. To this end, the agar was removed aseptically from the Petri dishes and placed in a sterile plastic bag with $100 \mathrm{~mL}$ of Tryptone phosphate-water. Homogenization was performed for 2 minutes in a Stomacher blender (Bag Mixer 400, Interscience). Then, serial dilutions were made and poured onto TSA. Plates were incubated at $37^{\circ} \mathrm{C}$ for $24 \mathrm{~h}$ before colonies were counted. All tests were run in triplicate.

\subsection{Statistical analysis}

A statistical analysis of data was performed through analyses of variance using Statgraphics ${ }^{\circledR}$ Plus for Windows 5.1. Homogeneous sample groups were obtained by using LSD test (95\% significance level). 


\section{RESULTS AND DISCUSSION}

\subsection{Properties of the film-forming dispersions}

\subsubsection{Particle size, $\mathrm{pH}$ and $\zeta$-potential}

Figure 1.1 shows the particle size distributions of FFDs. The dispersions showed similar distributions with a main peak at about 10-30 $\mu \mathrm{m}$. The fact that the formulation without buttermilk $\left(\mathrm{CS}_{1}: \mathrm{BM}_{0}\right)$ presents a particle size distribution which is detectable in the range of the equipment used, suggests the formation of amylose aggregates. The amylose concentration in the system is lower than the critical concentration for gel formation, since the dispersions did not form gels at rest when cooling. Nevertheless, this does not limit the possible association of the amylose chains, probably through the helical conformation zones. The addition of BM resulted in a displacement of the main peak towards slightly smaller particles, although distributions were wider. The samples with the lowest ratio of BM submitted to heat treatment exhibit a more similar distribution to the one containing only starch. Table 1.1 shows the results obtained for diameters $d_{3} 2$ and $d_{4,3}$ for every formulation. Coherently with the distributions shown in Figure 1.1, an increase in the BM ratio led to smaller average $d_{3,2}$ and $d_{4,3}$ diameters. This could be attributed to an inhibition effect of the amylose aggregation in the more complex composition system, while other smaller particles, such as fat globules from BM, contribute to the light dispersion pattern. The heat treatment of the buttermilk led to a slight increase in the average diameters, probably because heat induces whey protein denaturation and aggregation, thus increasing particle size. In this sense, Nicolai et al, 2011 report that the rate at which protein aggregation takes place increases as the temperature rises. The major whey protein in milk is $\beta$-lactoglobuline, and its aggregation kinetics is known to govern that of the whole whey protein (Ndoye et al., 2013). Two factors, namely heat and calcium concentration, affect whey protein aggregation. The presence of calcium divalent ions enhances heat-induced whey protein aggregation and strongly influences the size of whey protein aggregates (Ndoye et al, 2013, Nicolai et al, 2011). 


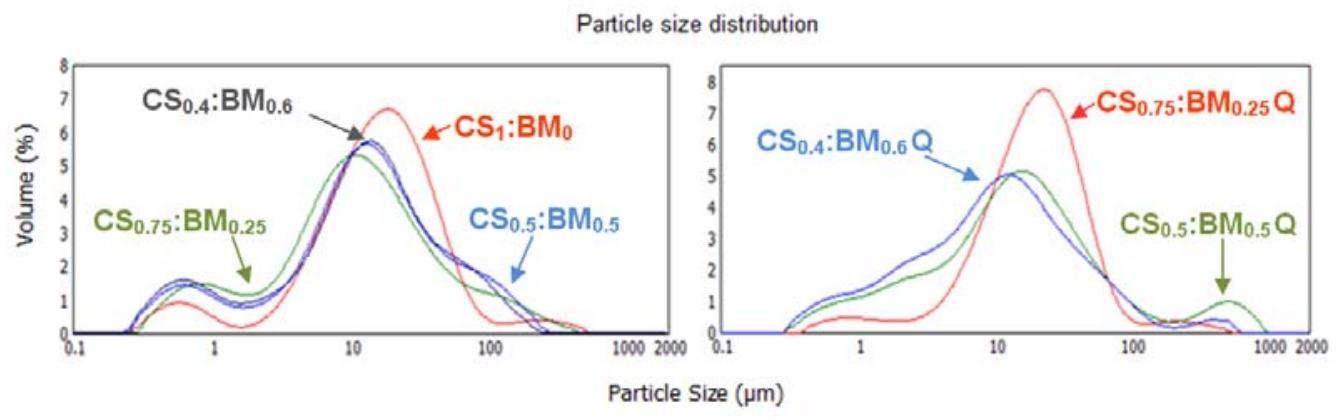

Figure 1.1. Particle size distribution of the FFD.

The values of $\zeta$-potential are shown in Table 1.1. The corresponding values for the sample without $\mathrm{BM}\left(\mathrm{CS}_{1}: \mathrm{BM}_{0}\right)$ were slightly negative, as a result of the adsorption of negative ions from the aqueous medium onto neutral starch chains. When adding BM, lipid particles appear in the medium probably coated by whey proteins, as well as whey protein aggregates when $\mathrm{BM}$ is heat treated. At the $\mathrm{pH}$ of the system (about 6), which is higher than the isoelectric point of the proteins, the carboxylic groups of amino acids are dissociated. Therefore, the adsorbed proteins induced a greater negative net charge on the particles present (Pelegrine \& Gasparetto, 2005). Heating BM provokes a significant $\mathrm{pH}$ increase, probably due to the partial depolymerization of protein and the release of aminoacids into the medium. The $\mathrm{pH}$ increase did not have a significant impact on $\zeta$ potential, due to the fact that it is still higher than the protein isoelectric point.

Particle size and $\zeta$-potential have a great impact on both the FFD stability and on the changes which take place during their drying step in the film formation process. The progressive water loss can promote flocculation of the particles and coalescence and creaming phenomena, which will affect the film's microstructure and functionality. The viscosity of the FFDs also plays an important role in the described phenomena, since it greatly contributes to the stabilization of the dispersion, thus limiting the coalescence and creaming which may imply a more homogeneous film structure. 
Table 1.1 Properties of film forming dispersions: average particle diameters, $\mathrm{pH}$, -potential and rheological parameters. Average values and standard deviation in brackets.

\begin{tabular}{|c|c|c|c|c|c|c|c|}
\hline & $\mathrm{d}_{32}(\mu \mathrm{m})$ & $\mathrm{d}_{43}(\mu \mathrm{m})$ & $\mathrm{pH}$ & $\zeta(\mathrm{mV})$ & $K(P a . s)^{n}$ & $\mathrm{n}$ & $\eta_{\mathrm{ap}}$ at $100 \mathrm{~s}^{-1}(\mathrm{~Pa} . \mathrm{s})$ \\
\hline $\mathrm{CS}_{1}: \mathrm{BM}_{0}$ & $5.43 \pm 0.11^{f}$ & $33 \pm 4^{d}$ & $6.250^{d}$ & $-3 . \pm 00.6^{d}$ & $0.02180 \pm 0.00014^{d}$ & $0.8706 \pm 0.0009^{a}$ & $0.01205 \pm 0.00007^{\mathrm{e}}$ \\
\hline $\mathrm{CS}_{0.75}: \mathrm{BM}_{0.25}$ & $3.62 \pm 0.17^{\mathrm{c}}$ & $29 \pm 3^{b c}$ & $6.150 .00^{a}$ & $-5.5 \pm 0.9^{c}$ & $0.01133 \pm 0.00012^{c}$ & $0.9090 \pm 0.0008^{b}$ & $0.00747 \pm 0.00006^{d}$ \\
\hline $\mathrm{CS}_{0.50}: \mathrm{BM}_{0.50}$ & $3.39 \pm 0.13^{b}$ & $27 \pm 3^{a b}$ & $6.220 .00^{c}$ & $-17 \pm 2^{a}$ & $0.00403 \pm 0.00006^{b}$ & $0.990 \pm 0.003^{\mathrm{cd}}$ & $0.00387 \pm 0.00006^{b}$ \\
\hline $\mathrm{CS}_{0.40}: \mathrm{BM}_{0.60}$ & $3.04 \pm 0.07^{\mathrm{a}}$ & $25.2 \pm 1.9^{a}$ & $6.210 .00^{b}$ & $-17 \pm 2^{a}$ & $0.00293 \pm 0.00015^{a}$ & $1.007 \pm 0.008^{\mathrm{e}}$ & $0.00303 \pm 0.00006^{a}$ \\
\hline $\mathrm{CS}_{0.75}: \mathrm{BM}_{0.25} \mathrm{Q}$ & $9.07 \pm 0.18^{9}$ & $26 \pm 3^{a}$ & $6.8030 .006^{\mathrm{e}}$ & $-6.0 \pm 0.7^{c}$ & $0.0109 \pm 0.0006^{c}$ & $0.910 \pm 0.008^{b}$ & $0.00725 \pm 0.00007^{c}$ \\
\hline $\mathrm{CS}_{0.50}: \mathrm{BM}_{0.50} \mathrm{Q}$ & $4.38 \pm 0.11^{\mathrm{e}}$ & $30 \pm 5^{c}$ & $6.830 .00^{f}$ & $-7.861 .06^{b}$ & $0.00420 \pm 0.00014^{b}$ & $0.979 \pm 0.006^{c}$ & $0.0038 \pm 0.0000^{b}$ \\
\hline $\mathrm{CS}_{0.40}: \mathrm{BM}_{0.60} \mathrm{Q}$ & $3.85 \pm 0.07^{d}$ & $27 \pm 2^{\mathrm{ab}}$ & $6.80 .0^{\mathrm{e}}$ & $-17 \pm 5^{a}$ & $0.0032 \pm 0.0002^{a}$ & $0.993 \pm 0.009^{d}$ & $0.00305 \pm 0.00007^{a}$ \\
\hline
\end{tabular}

Different superscripts $(a, b, c, d)$ indicate significant differences among film-forming dispersions $(p<0.05)$. 


\subsubsection{Rheological behaviour}

Figure 1.2 shows the flow curves for the different film-forming dispersions, and the rheological parameters resulting from fitting the Ostwald de Waale law (Equation 1.3) are shown in Table 1.1, together with the apparent viscosity at $100 \mathrm{~s}^{-1}$. The FFDs exhibited shear thinning behaviour in the range of the shear rate considered, but tend towards Newtonian behaviour when the BM ratio increases. The formulation without BM $\left(\mathrm{CS}_{1}: \mathrm{BM}_{0}\right)$ showed the lowest flow behaviour index $(\mathrm{n})$, which tended towards 1 as the $\mathrm{BM}$ ratio increased in the mix. The formulations with the highest quantity of BM $\left(\mathrm{CS}_{0.40}: \mathrm{BM}_{0.60}\right.$ and $\left.\mathrm{CS}_{0.40}: \mathrm{BM}_{0.60} \mathrm{Q}\right)$ exhibited Newtonian behaviour and the lowest values of viscosity. No notable effect of the thermal treatment of BM was observed on the sample rheological behaviour. This indicates that the possible protein aggregations did not have an impact on the flow properties.

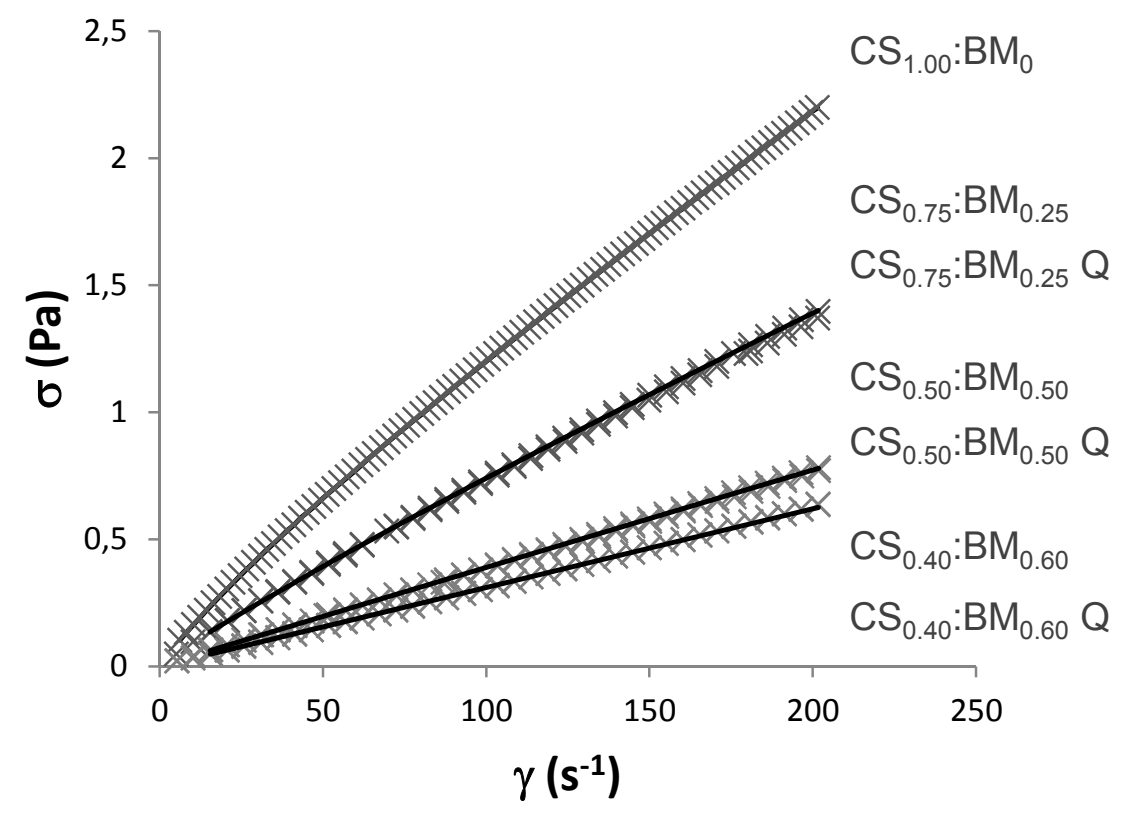

Figure 1.2 Typical flow curves, at $25^{\circ} \mathrm{C}$, of the film-forming dispersions. Fitting to the Ostwald de Waale law (continuous line).

As the BM ratio increased in the mix, a progressive decrease in apparent viscosity $\left(\eta_{\mathrm{ap}}\right)$ was observed, both with heated and non-heated BM. This can be explained by to the lower average molecular weights of the components (the highest molecular weight 
compound of BM is whey protein, whose molecular size is lower than that of starch chains) and the subsequent decrease in the hydrodynamic volume of polymeric chains. For macromolecules, the higher the molecular weight, the higher the hydrodynamic volume and the higher thickening power. Additionally, the incorporation of ionic and polar solutes from BM makes the solvent poor for the macromolecules, which, in turn, reduces their hydrodynamic volume and intrinsic viscosity (Dickinson and Stainsby, 1982). Greater hydrodynamic volumes are more sensitive to shear rate since they can be easily deformed during shear giving rise to the shear-thinning effects. As commented on above, as the BM ratio increased, the formation of amylose aggregates seemed to be limited, which could also contribute to the drop in viscosity.

\subsection{Film Properties}

\subsubsection{Microstructure of the films}

Figure 1.3a shows the cross-section SEM images of CS films and CS:BM blend films with non-heated BM, while Figure 1.3b shows the corresponding images of CS:BM blend films with heated $B M$. For films without buttermilk $\left(\mathrm{CS}_{1}: \mathrm{BM}_{0}\right)$, a rather homogenous structure was observed, with linear formations in the direction of the water flow during film drying, which could be attributed to amylose crystalline associations. Different authors (Gelders et al. 2004; Famá et al. 2005), have reported the formation of $V$ type crystalline shapes of oriented amylose helixes, which are formed by complexing lipids or other non-polar molecules, which can be endogens of starch. The formation of these helicoidal complexes and their aggregates is coherent with the results commented on in section 3.1.1. On the other hand, the continuous matrix fractures more irregularly when the BM content is high, due to a heterogeneous distribution of components with areas of different mechanical resistance. This suggests the coexistence of two phases: a starchrich phase and a protein-rich phase, resulting from the lack of compatibility of both polymers. This occurs for both film series, with and without BM heating.

In films with a higher BM content, small irregularly-shaped lipid particles are clearly observed corresponding to solid dairy fat during film formation (in many cases, the hole that these left as the film is cryofractured is observed). In films with heated buttermilk, a great deal fewer holes from irregular lipid particles were observed. When comparing the two films with the highest buttermilk ratio, it was observed that films with heated BM showed a better inclusion of the lipids in the matrix and a more cohesive structure, which 
could be explained by the formation of protein gel during the film drying, as reported by Nicolai et al. (2011). Zuniga et al. (2010) also observed curved linear aggregates (strands) of milk whey protein caused by heating at $\mathrm{pH} 6.8$, which at a high enough concentration, and in the presence of salts, would form gel.

A)

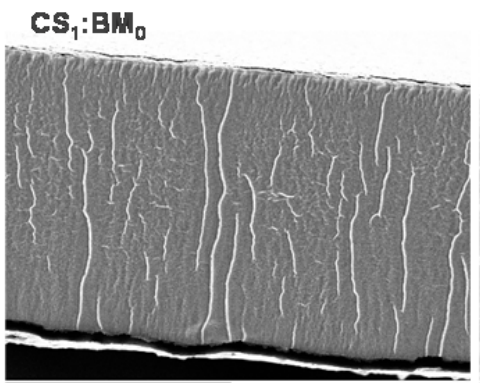

$\mathrm{CS}_{0.75}: \mathrm{BM}_{0.25}$
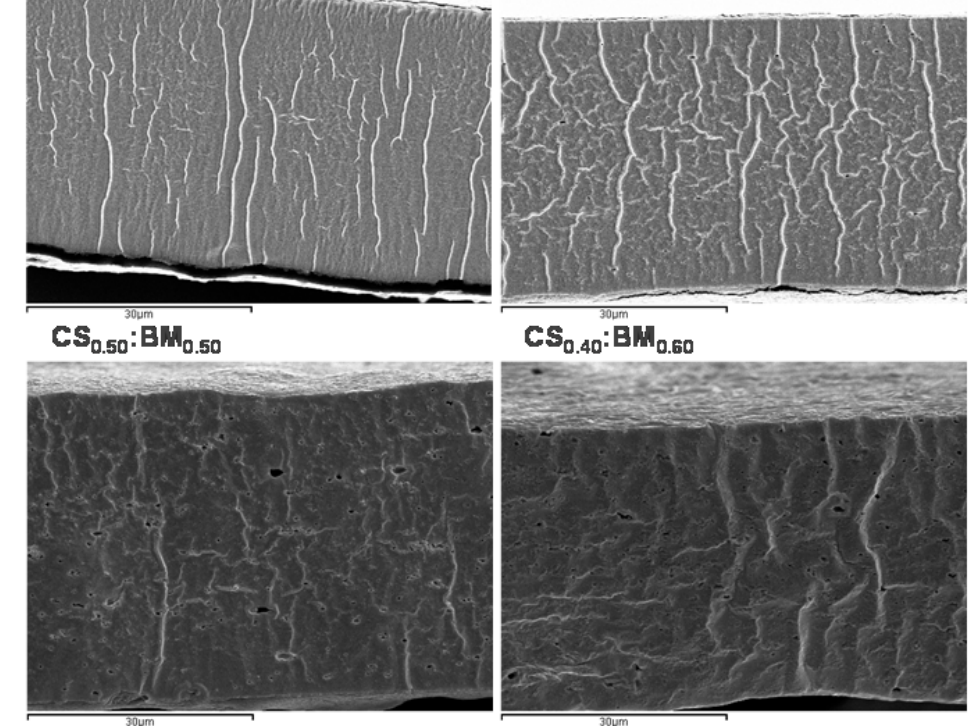

$\mathrm{CS}_{0.40}: \mathrm{BM}_{0.60}$

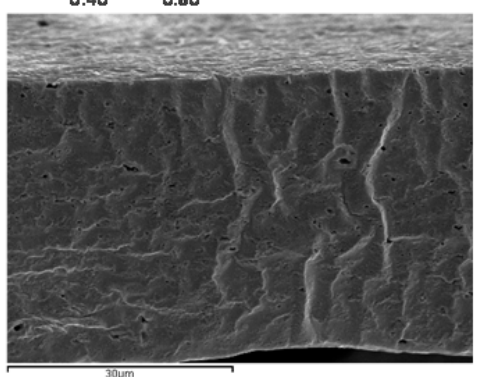

B)
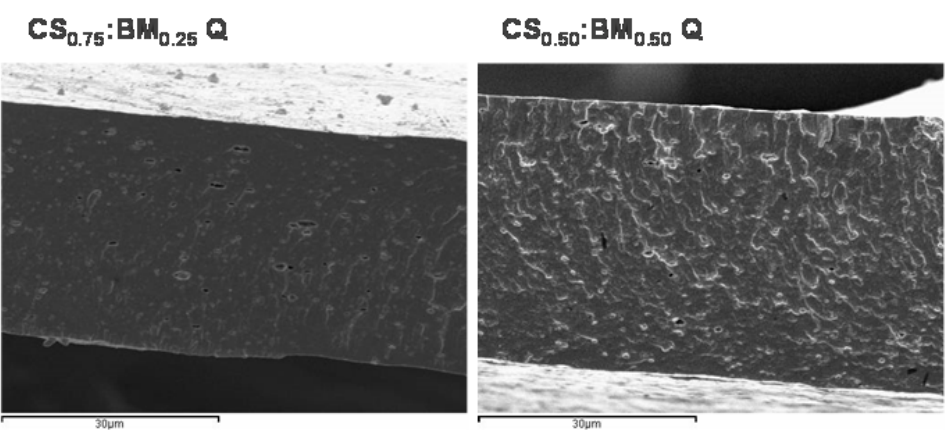

$\mathrm{CS}_{0.40}: \mathrm{BW}_{0.60} \mathrm{Q}$

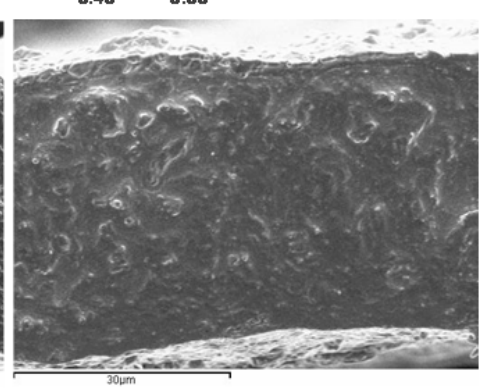

Figure 1.3 a) SEM images (30 $\mu \mathrm{m}$ bars) of the cross-sections of the films containing non heated $\mathrm{BM}$, equilibrated with $\mathrm{P}_{2} \mathrm{O}_{5}$ at $25^{\circ} \mathrm{C}$ and b) SEM images of the cross-sections of the films containing heated $\mathrm{BM}$ equilibrated with $\mathrm{P}_{2} \mathrm{O}_{5}$ at $25^{\circ} \mathrm{C}$.

Figure 1.4 presents the topographic images of the surface of the films obtained by AFM (Phase Imaging mode). In these images, the differences in the mechanical response (or other properties) at different points on the surface of each sample can be seen. In the $\mathrm{CS}_{1}: \mathrm{BM}_{0}$ sample, the heterogeneous response of different surface zones can be observed, which could be explained by the presence of crystalline areas of amylose. In 
films with BM, the surface heterogeneity increases along with the ratio of BM, which agrees with the formation of two phases in the polymer matrix: one rich in starch and the other in proteins, each one of them with different properties. The area of zones with different surface properties increased when the BM proportion rose, which confirms the phase separation process with the formation of a great amount of protein-rich fraction.

a: $\mathrm{CS}_{0.75}: \mathrm{BM}_{0.25}$

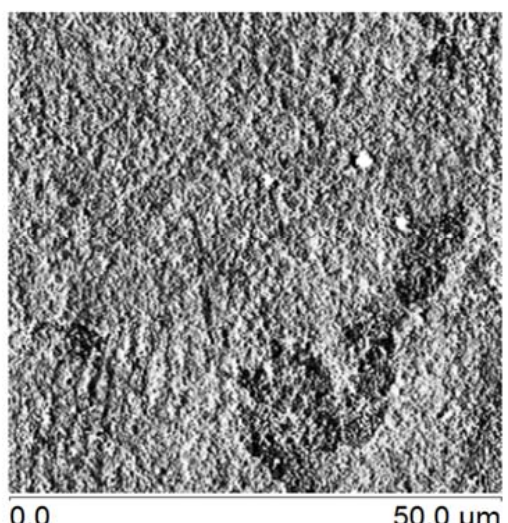

0.0

b: $\mathrm{CS}_{0.75}: \mathrm{BM}_{0.25} \mathrm{Q}$

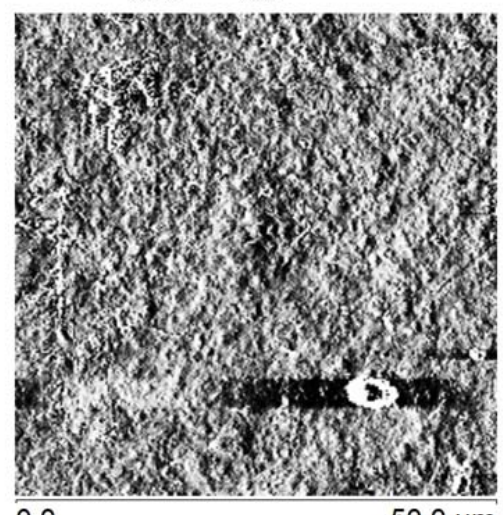

0.0

$50.0 \mu \mathrm{m}$

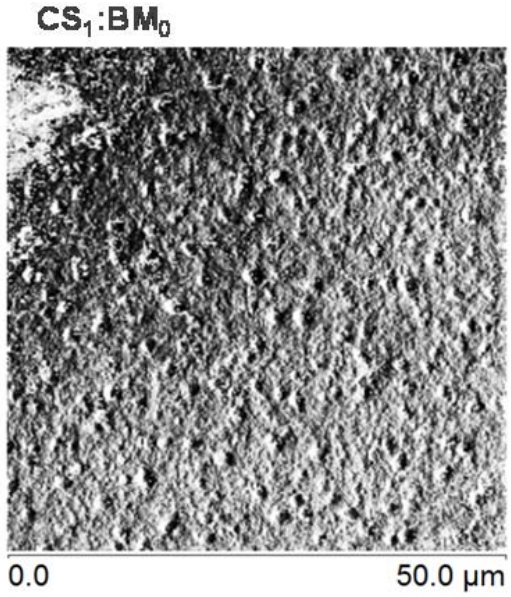

$$
\text { a: } \mathrm{CS}_{0.50}: \mathrm{BM}_{0.50}
$$

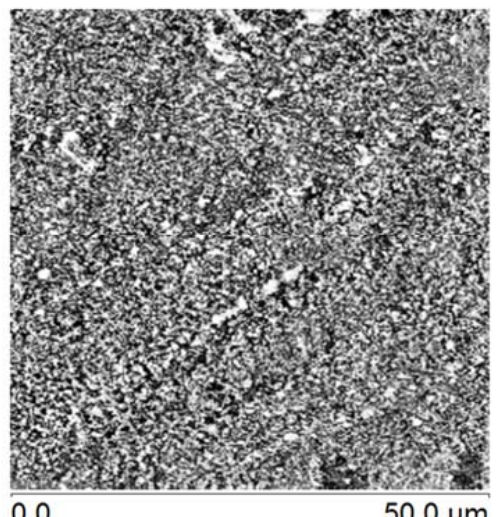

0.0

b: $\mathrm{CS}_{0.50}: \mathrm{BM}_{0.50} \mathrm{Q}$

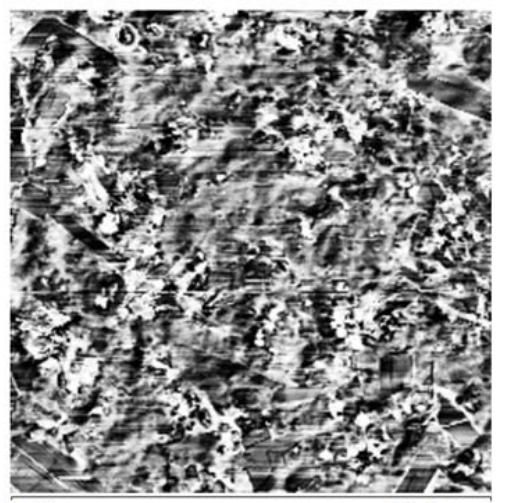

$50.0 \mu \mathrm{m}$

$$
\text { a: } \mathrm{CS}_{0.40}: \mathrm{BM}_{0.60}
$$

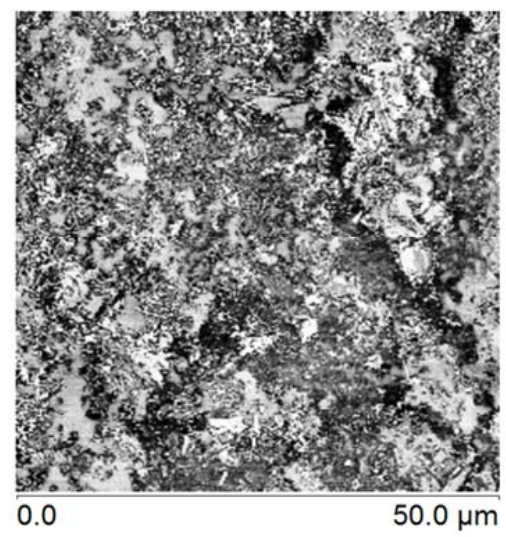

b: $\mathrm{CS}_{0.40}: \mathrm{BM}_{0.60} \mathrm{Q}$

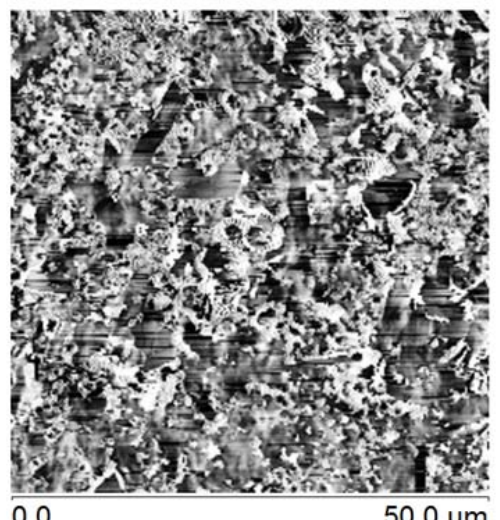

$50.0 \mu \mathrm{m}$

Figure 1.4 AFM maps (phase image) of the different starch film formulations with non heated (a) and heated (b) BM (observations of $50 \times 50 \mu \mathrm{m}$ ). 


\subsubsection{Mechanical properties and equilibrium moisture content}

Table 1.2 shows the thickness, the mechanical parameters and the equilibrium moisture content of the films equilibrated at $53 \% \mathrm{RH}$. Thickness was significantly affected by the heat treatment $(p<0.05)$ but not by the CS:BM ratio $(p>0.05)$. Apparently, the changes induced by the heat treatment on the structure of buttermilk greatly affect the interactions with corn starch and the molecular arrangement of the film components, causing an increase in film thickness.

Table 1.2 Film thickness, mechanical parameters (EM, TS, \% E) of films equilibrated at

$53 \% \mathrm{RH}$ and $25^{\circ} \mathrm{C}$, equilibrium moisture content in dry basis $\left(X_{w}\right)$ and water vapour permeability $\left(\mathrm{g} \cdot \mathrm{mm} / \mathrm{kPa} \cdot \mathrm{h} \cdot \mathrm{m}^{2}\right) \times 10^{7}$. Average values and standard deviation in brackets.

\begin{tabular}{lcccccc}
\hline & Thickness $(\mu \mathrm{m})$ & $\mathrm{EM}(\mathrm{MPa})$ & $\mathrm{TS}(\mathrm{MPa})$ & $\mathrm{E} \%$ & $\mathbf{X}_{\mathrm{w}}$ (d.b.) & WVP \\
\hline $\mathrm{CS}_{1}: \mathrm{BM}_{0}$ & $45 \pm 4^{\mathrm{a}}$ & $1331 \pm 91^{\mathrm{e}}$ & $31 \pm 6^{\mathrm{e}}$ & $2.8 \pm 0.6^{\mathrm{bc}}$ & $8.7 \pm 1.2^{\mathrm{c}}$ & $12.81 . \pm 2^{\mathrm{a}}$ \\
\hline $\mathrm{CS}_{0.75}: \mathrm{BM}_{0.25}$ & $45 \pm 2^{\mathrm{a}}$ & $849 \pm 83^{\mathrm{d}}$ & $8 \pm 3^{\mathrm{d}}$ & $1.1 \pm 0.5^{\mathrm{a}}$ & $8.10 \pm 0.05^{\mathrm{abc}}$ & $12.4 \pm 0.5^{\mathrm{a}}$ \\
\hline $\mathrm{CS}_{0.50}: \mathrm{BM}_{0.50}$ & $47 \pm 4^{\mathrm{ab}}$ & $304 \pm 171^{\mathrm{b}}$ & $5.0 \pm 1.9^{\mathrm{c}}$ & $3 \pm 3^{\mathrm{c}}$ & $8.1 \pm 0.8^{\mathrm{bc}}$ & $15.16 \pm 1.11^{\mathrm{ab}}$ \\
$\mathbf{C S}_{0.40}: \mathrm{BM}_{0.60}$ & $51 \pm 4^{\mathrm{bc}}$ & $8.0 \pm 1.1^{\mathrm{a}}$ & $0.66 \pm 0.09^{\mathrm{a}}$ & $16 \pm 4^{\mathrm{d}}$ & $17.3 \pm 0.3^{\mathrm{d}}$ & $20 \pm 4^{\mathrm{c}}$ \\
$\mathbf{C S}_{0.75}: \mathrm{BM}_{0.25} \mathrm{Q}$ & $57.0 \pm 1.1^{\mathrm{d}}$ & $540 \pm 99^{\mathrm{c}}$ & $1.8 \pm 0.6^{\mathrm{ab}}$ & $0.44 \pm 0.10^{\mathrm{a}}$ & $7.79 \pm 0.08^{\mathrm{ab}}$ & $17 \pm 4^{\mathrm{bc}}$ \\
\hline $\mathbf{C S}_{0.50}: \mathrm{BM}_{0.50} \mathrm{Q}$ & $52 \pm 4^{\mathrm{c}}$ & $270 \pm 33^{\mathrm{b}}$ & $3.0 \pm 1.4^{\mathrm{abc}}$ & $1.3 \pm 0.5^{\mathrm{a}}$ & $8.4 \pm 0.8^{\mathrm{bc}}$ & $15 \pm 2^{\mathrm{ab}}$ \\
$\mathbf{C S}_{0.40}: \mathrm{BM}_{0.60} \mathrm{Q}$ & $52 \pm 6^{\mathrm{c}}$ & $342 \pm 84^{\mathrm{b}}$ & $4.1 \pm 0.8^{\mathrm{bc}}$ & $1.6 \pm 0.5^{\mathrm{ab}}$ & $7.2 \pm 0.4^{\mathrm{a}}$ & $16 \pm 2^{\mathrm{b}}$ \\
\hline
\end{tabular}

Different (a, b, c, d) superscripts indicate significant differences among films $(p<0.05)$.

The mechanical parameters obtained for the $\mathrm{CS}_{1}: \mathrm{BM}_{0}$ films are similar to those reported by Jiménez et al. (2012). The addition of BM to the formulation significantly affected the elastic modulus and the tensile strength at break $(p<0.05)$. For both series, as the BM proportion increased the films became less rigid and less resistant, which is coherent with the appearance of a dispersed phase of protein-rich polymer which limits the cohesion forces of the starch matrix. The incompatibility of both materials results in an interrupted starch matrix, leading to the reduction of its mechanical resistance. In addition, BM incorporation is associated with a high proportion of non-polymeric solids, such as lactose and salts, which do not contribute to the strength of the polymeric network and that promote the plasticization of the matrix. However, in films with the 
highest amount of buttermilk, heating had a positive impact on the mechanical behaviour, since EM and TS were much higher than those of the non-heated sample. As commented on above, in films with heated BM, aggregates may form a gel during the film drying when the critical concentration for gel formation is reached, which seems to have a positive impact (increased EM and TS) on the mechanical properties. This gel is formed by cross-linked protein strands above a critical concentration and this aggregation progresses when the film loses the remaining water till it is totally dry. Moreover, the presence of calcium salts in the medium reduces the critical concentration for gel formation, having a positive impact on the gel strength (Nicolai et al., 2011). According to Baussay et al. (2004), the critical gelation concentration at $\mathrm{pH} 7$ is less than $1 \mathrm{gL}^{-1}$ in $1 \mathrm{mM} \mathrm{CaCl}_{2}\left(0.111 \mathrm{gL}^{-1}\right)$. In the films studied, the protein concentration for $\mathrm{CS}_{0.4}: \mathrm{BM}_{0.6} \mathrm{Q}$ sample was $5.4 \mathrm{gL}^{-1}$ at the beginning of the film drying, while BM provided the medium with a substantial amount of salts $\left(1.3 \mathrm{gL}^{-1}\right)$ including $\mathrm{CaCl}_{2}$. Consequently, it can be concluded that a protein gel was formed during film drying when heating was applied to BM formulations, which contributes to the cohesion of the film structure, having a positive impact on the stiffness and resistance of the films.

The stretchability of the films depended on the BM ratio and the heat treatment. For films with only corn starch, the value was in the order of that obtained by Jimenez et al. (2012) for films with the same composition. In films with non-heated BM, a significant elongation increase was found when the $\mathrm{BM}$ ratio was $60 \%$. The $\mathrm{CS}_{0.4}: \mathrm{BM}_{0.6}$ formulation was the most extensible, while showing the lowest EM and TS values (Table 1.2). This behaviour is explained by both the high proportion of lactose in the film coming from BM (which acts as a plasticizer), and the high equilibrium moisture content of these films (Table 1.2). The high ratio of ionic and low molecular weigh solutes (salts and lactose) contributed to such a high moisture content. So, the results suggest that the highest BM proportion is critical, since it introduces a notable amount in this type of solids which favours the water sorption capacity of the film by solvent effects when they equilibrate at $53 \%$ RH (Fabra et al., 2010). The plasticizing effects of the adsorbed water and lactose make these films both very soft and poorly resistant, even though they are very extensible. However, at the same BM proportion, films with heated BM appeared less hygroscopic and extensible (Table 1.2). It is likely that salts and lactose were trapped in the formed protein gel network, rendering them less available for water interaction, thus reducing the water retention capacity of the film. Heating the BM greatly reduced the film extensibility in all cases, which agrees with the formation of the above- mentioned protein network after the gelling process. This reduces the possibility of the polymer 
chain slippage during the extension test, in line with the cross-linking effect induced by gel formation.

\subsubsection{Water vapour permeability}

Values of water vapour permeability (WVP) at $25{ }^{\circ} \mathrm{C}$ and $53-100 \% \mathrm{RH}$ gradient are shown in Table 1.2. The WVP found for films without BM is comparable to that reported in previous studies (Jiménez et al., 2012). The addition of non-heated BM up to $50 \%$ did not entail significant changes in the water vapour barrier properties of the films. The presence of lipid compounds incorporated with BM (which, in principle, could favour the barrier effects) is actually mitigated because of the lower structural cohesion of the films caused by the non-compatible compounds, which favours the mass transfer across the film. In this sense, the film formulation with the highest content of non-heated BM, presented the highest WVP value $(p<0.05)$, which can be attributed to its remarkable structural heterogeneity and to its higher moisture content, which plasticizes the matrix, promoting molecular mobility and mass transfer through the film. Nevertheless, the equivalent films with heated BM showed lower WVP values, in agreement with the previously commented on protein network formation; this contributed to the greater cohesion of the film components, limiting mass transfer processes.

\subsubsection{Optical properties}

Table 1.3 shows the colour parameters of all formulations: lightness $\left(L^{*}\right)$, chrome $\left(C_{a b}{ }^{*}\right)$ and hue $\left(\mathrm{h}_{\mathrm{ab}}{ }^{*}\right)$, together with the whiteness index $(\mathrm{WI})$. The incorporation of BM into CS films, provoked a drop in the lightness of films with non-heated BM, which was statistically significant for $\mathrm{CS}_{0.40}: \mathrm{BM}_{0.60}$ samples $(\mathrm{p}<0.05)$. On the contrary, the films with heated BM experienced a significant increase in lightness $(p<0.05)$ as compared to the corn starch films. This difference in the lightness behaviour can be attributed to the different film structure, which affects film-light interactions and final colour parameters. The saturation of yellowness of the films notably $(p<0.05)$ increased for both series along with the BM ratio. This is due to the natural colour of the BM (slightly yellow) which affects the overall matrix colour. The whiteness index (WI) was coherently modified, and it decreased as the BM proportion increased. These effects were less sensitive to the 
BM ratio when it was heated due to the heat induced structural differences commented on above.

Table 1.3 Colour coordinates ( $L^{*}$ : Lightness, $C_{a b}{ }^{*}$ : Chrome and $h_{a b}{ }^{*}$ : hue) and whiteness index (WI) of the films. Average values and standard deviation in brackets.

\begin{tabular}{lcccc}
\hline & $\mathrm{L}^{*}$ & $\mathrm{C}_{\mathrm{ab}}{ }^{*}$ & $\mathrm{~h}_{\mathrm{ab}}{ }^{*}$ & $\mathrm{WI}$ \\
\hline $\mathrm{CS}_{1}: \mathrm{BM}_{0}$ & $79.2 \pm 1.9^{\mathrm{b}}$ & $2.9 \pm 0.2^{\mathrm{a}}$ & $69 \pm 4^{\mathrm{a}}$ & $79.0 \pm 1.9^{\mathrm{cd}}$ \\
$\mathrm{CS}_{0.75}: \mathrm{BM}_{0.25}$ & $77.6 \pm 1.3^{\mathrm{ab}}$ & $7 \pm 2^{\mathrm{b}}$ & $113 \pm 7^{\mathrm{d}}$ & $76.4 \pm 1.8^{\mathrm{bc}}$ \\
\hline $\mathrm{CS}_{0.50}: \mathrm{BM}_{0.50}$ & $78.4 \pm 1.1^{\mathrm{b}}$ & $10 \pm 3^{\mathrm{c}}$ & $102 \pm 5^{\mathrm{c}}$ & $76.0 \pm 1.3^{\mathrm{b}}$ \\
\hline $\mathrm{CS}_{0.40}: \mathrm{BM}_{0.60}$ & $76 \pm 4^{\mathrm{a}}$ & $16 \pm 3^{\mathrm{e}}$ & $93 \pm 5^{\mathrm{b}}$ & $71 \pm 5^{\mathrm{a}}$ \\
$\mathbf{C S}_{0.75}: \mathrm{BM}_{0.25} \mathrm{Q}$ & $84.2 \pm 0.6^{\mathrm{c}}$ & $14.0 \pm 1.0^{\mathrm{de}}$ & $93.4 \pm 1.2^{\mathrm{b}}$ & $78.2 \pm 0.2^{\mathrm{bcd}}$ \\
$\mathrm{CS}_{0.50}: \mathrm{BM}_{0.50} \mathrm{Q}$ & $83.2 \pm 0.7^{\mathrm{c}}$ & $11.9 \pm 1.7^{\mathrm{cd}}$ & $96.0 \pm 1.6^{\mathrm{b}}$ & $79.4 \pm 1.1^{\mathrm{d}}$ \\
\hline $\mathbf{C S}_{0.40}: \mathrm{BM}_{0.60} \mathrm{Q}$ & $82.4 \pm 0.5^{\mathrm{c}}$ & $15.7 \pm 1.0^{\mathrm{e}}$ & $91.9 \pm 0.3^{\mathrm{b}}$ & $76.5 \pm 0.9^{\mathrm{bc}}$ \\
\hline
\end{tabular}

Different superscripts $(a, b, c, d)$ indicate significant differences among films $(p<0.05)$.

Figure 1.5 shows the spectral distribution of the internal transmittance $\left(T_{i}\right)$ of the films, as an indicator of the translucency level. The internal transmittance decreased as the BM content increased, mainly at low wavelengths, which indicates a rise in the film opacity. This is coherent with the formation of a more heterogeneous structure with changes in the refraction index through the film structure, which promotes light dispersion. As the ratio of dispersed phase (BM components) becomes higher, a loss of transparency occurs. The films with heated BM showed smoother curves as compared to non-heated, and were less transparent. This also agrees with the formation of a more compact and complex structure, in line with the formation of the protein gel and network (as shown in Figure 1.3 and Figure 1.4), which caused the loss of film transparency.

The gloss values of the films are shown in Table 1.4. The measurements were taken at a $60^{\circ}$ angle, for the requirements of the standard to be fulfilled, according to the gloss intensity of the samples. Every film had average gloss values ranging between 10 and 40 , meaning that they could be considered mostly matt. The incorporation of non-heated buttermilk caused the starch films to lose gloss, whereas the opposite was observed when they contain heated buttermilk. The generation of a different structure due to 
heating and the promotion of the protein network favours gloss development, in all likelihood due to the fact that the surface formed is smoother.

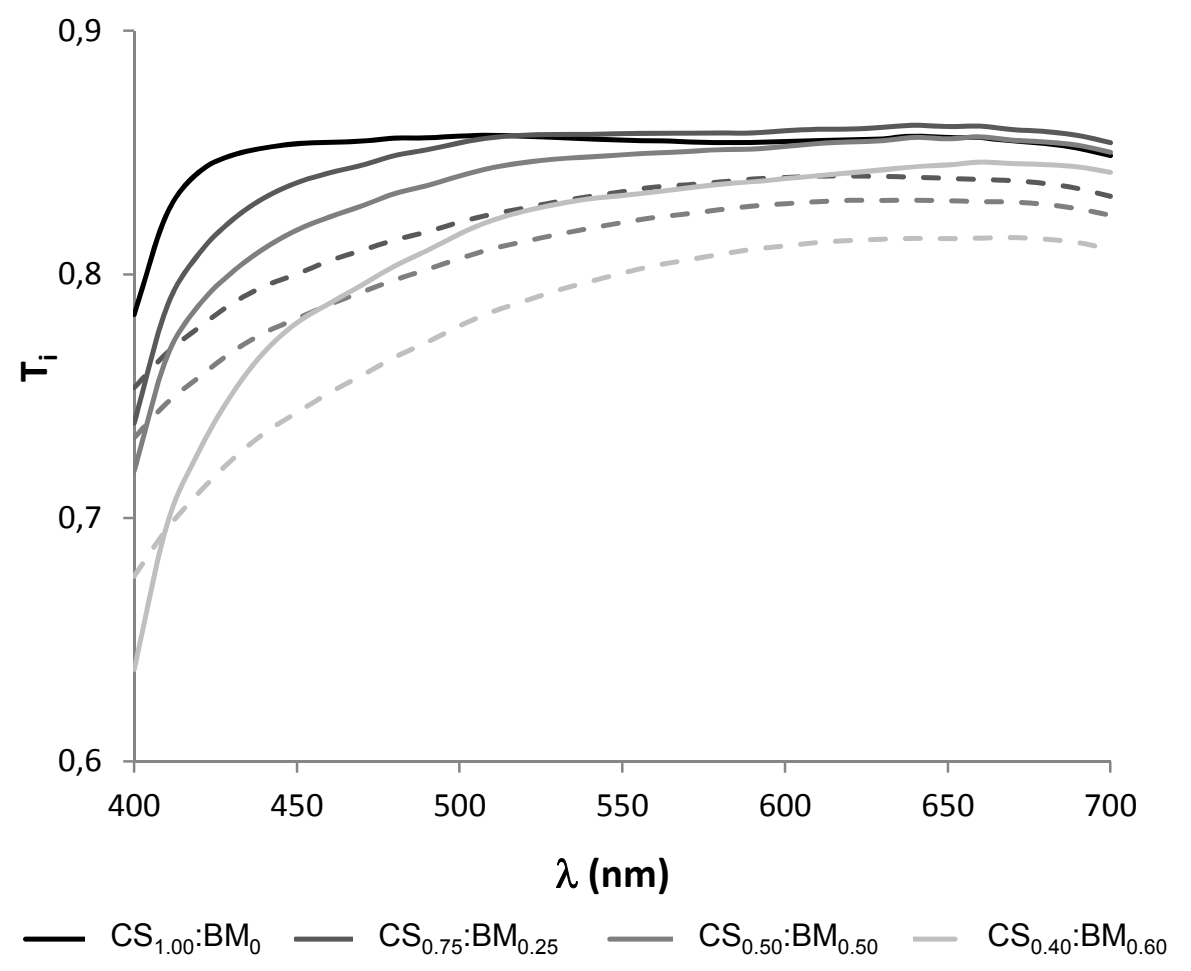

Figure 1.5 Spectral distribution of internal transmittance of films with non-heated buttermilk (solid lines) and heated buttermilk (dashed lines).

Table 1.4 also shows the surface roughness values $\left(R_{a}, R_{q}\right.$ and Image Surface Area Difference \%), obtained from the AFM images. It was observed that, despite the high variability of the roughness values, a tendency can be established: the rougher the surface, the lower the gloss, as found by other authors (Villalobos et al. 2005; Fabra et al. 2009). The $\mathrm{CS}_{0.40}: \mathrm{BM}_{0.60}$ films showed the highest roughness and the lowest gloss $(p<0.05)$ and at the highest buttermilk ratio, heat treatment led to a gloss increase (as previously commented on) and a decrease in roughness. 
Table 1.4 Gloss values at $60^{\circ}$, surface roughness values $\left(R_{a}\right.$ and $\left.R_{q}\right)$ obtained from AFM images and Trolox equivalent antioxidant activity (TEAC) expresed as the concentration of dry film $(\mathrm{g} / \mathrm{L})$ yielding the same absorbance percentage reduction than Trolox $1 \mathrm{mM}$.

\begin{tabular}{|c|c|c|c|c|c|}
\hline & Gloss $\left(60^{\circ}\right)$ & $R_{q}(n m)$ & $R_{a}(n m)$ & $\begin{array}{c}\text { Surface area } \\
\text { difference (\%) }\end{array}$ & $\begin{array}{l}\text { TEAC ( } g \text { of dry } \\
\text { film / I) }\end{array}$ \\
\hline $\mathrm{CS}_{1}: \mathrm{BM}_{0}$ & $20 \pm 8^{c}$ & $64 \pm 13^{a}$ & $45 \pm 8^{a}$ & $1.4 \pm 0.4^{\mathrm{ab}}$ & n.d. ${ }^{*}$ \\
\hline $\mathrm{CS}_{0.75}: \mathrm{BM}_{0.25}$ & $14 \pm 4^{b}$ & $42 \pm 6^{a}$ & $32 \pm 4^{a}$ & $0.77 \pm 0.10^{a}$ & n.d. ${ }^{*}$ \\
\hline $\mathrm{CS}_{0.50}: \mathrm{BM}_{0.50}$ & $13 \pm 3^{a b}$ & $62 \pm 21^{a}$ & $45 \pm 15^{a}$ & $0.6 \pm 0.2^{a}$ & n.d.* \\
\hline $\mathrm{CS}_{0.40}: \mathrm{BM}_{0.60}$ & $10 \pm 2^{a}$ & $265 \pm 21^{c}$ & $208 \pm 11^{c}$ & $5 \pm 2^{c}$ & n.d.* \\
\hline $\mathrm{CS}_{0.75}: \mathrm{BM}_{0.25} \mathrm{Q}$ & $35 \pm 8^{\mathrm{de}}$ & $80 \pm 19^{a}$ & $56 \pm 10^{a}$ & $1.73 \pm 0.14^{\mathrm{ab}}$ & 337 \\
\hline $\mathrm{CS}_{0.50}: \mathrm{BM}_{0.50} \mathrm{Q}$ & $39 \pm 9^{e}$ & $75 \pm 31^{a}$ & $57 \pm 21^{a}$ & $1.0 \pm 0.6^{a b}$ & 98 \\
\hline $\mathrm{CS}_{0.40}: \mathrm{BM}_{0.60} \mathrm{Q}$ & $33 \pm 4^{d}$ & $142 \pm 31^{b}$ & $109 \pm 20^{b}$ & $2.5 \pm 0.6^{b}$ & 93 \\
\hline
\end{tabular}

Different superscripts $(a, b, c, d)$ indicate significant differences among films $(p<0.05)$.

${ }^{*}$ n.d.: non detected.

\subsubsection{Antioxidant activity}

The antioxidant capacity of BM (heated and non-heated) was analyzed and expressed as the Trolox Equivalent Antioxidant Capacity (TEAC), or the concentration of BM $(\mathrm{g} / \mathrm{L})$ that produces the same inhibition percentage of absorbance as $1 \mathrm{mM}$ trolox solution. The TEAC values were 76 and $70 \mathrm{~g} \mathrm{BM/L}$, respectively for heated and non-heated BM. This means that the thermal treatment did not notably affect the antioxidant capacity of the components.

The antioxidant potential of proteins derived from dairy products has been repeatedly reported in literature (Allen and Wrieden, 1982; Colbert and Decker, 1991; Stuchell and Krochta, 1995; Maté et al., 1996). Lactoferrin, present in the whey fraction of milk, has affinity for iron and inhibits iron-catalyzed oxidation in iron-supplemented infant formulas (Satué-Gracia et al., 2000) and liposomal containing phospholipid systems (Wakabayashi et al., 1999). Wong \& Kitts (2003) concluded that the reducing activity in buttermilk was mainly attributed to the sulfhydryl content.

Table 1.4 shows the TEAC values of the films, expressed as the concentration of dry film ( $g$ of dry film/L) that produces the same inhibition percentage of absorbance as $1 \mathrm{mM}$ 
trolox solution. Films without buttermilk and those with non-heated BM did not exhibit antioxidant activity, as opposed to those with heated BM. Assuming that the activity was due to BM components, the TEAC values can be referred to as $\mathrm{g} B M / L$. In this case, the values were 62,36 and 27 , respectively, for samples with 25,50 and $60 \%$ of BM. These values are lower than that obtained for isolated BM, which indicates a greater antioxidant capacity of BM when it is embedded in the film after heating; the higher the BM ratio in the film, the more activity.

Mills et al., 2011 report that the antioxidant components in the BM are released by heat treatment. Although it was not observed for isolated samples of BM, it was shown for the $\mathrm{BM}$ in the films, which could be due to the action of both thermal treatment and shear applied for homogenization of the film forming dispersions. In this sense, it is remarkable that BM exhibited a greater antioxidant capacity in the film than when isolated. This could be attributed to a certain degree of protein depolymerization during the combined homogenization thermal treatment when obtaining film forming dispersions, with the subsequent release of some active peptides.

\subsubsection{Antimicrobial activity}

Figure 1.6 shows the growth curves of Listeria innocua over a period of 13 storage days at $10^{\circ} \mathrm{C}$. The two sets of data represent the bacterial growth on control plates (without coating) and on those coated with BM $\left(44.8 \mathrm{~g} / \mathrm{m}^{2}\right)$. Both sets of data showed a bacterial growth starting at 2 log and reaching 8.8 logs UFC/cm ${ }^{2}$ after 13 days. The similarity between the two curves reveals that BM had no effect on the growth of $L$. innocua under the conditions tested. This apparently contradicts the results found in literature, pointing to the antibacterial effect of some buttermilk components, such as lactoferrin and its derived peptides (Farnaud \& Evans, 2003; Jenssen \& Hancock, 2009; Mishra et al., 2013). This was probably caused by the low content of lactoferrin (bovine milk contains between $0.02-0.35 \mathrm{mg} / \mathrm{mL}$ according to Madureira et al, (2007). It can therefore be stated that, at this low concentration, and accompanied by high proportions of nutritional compounds, the antimicrobial effect of these agents could not be detected. 


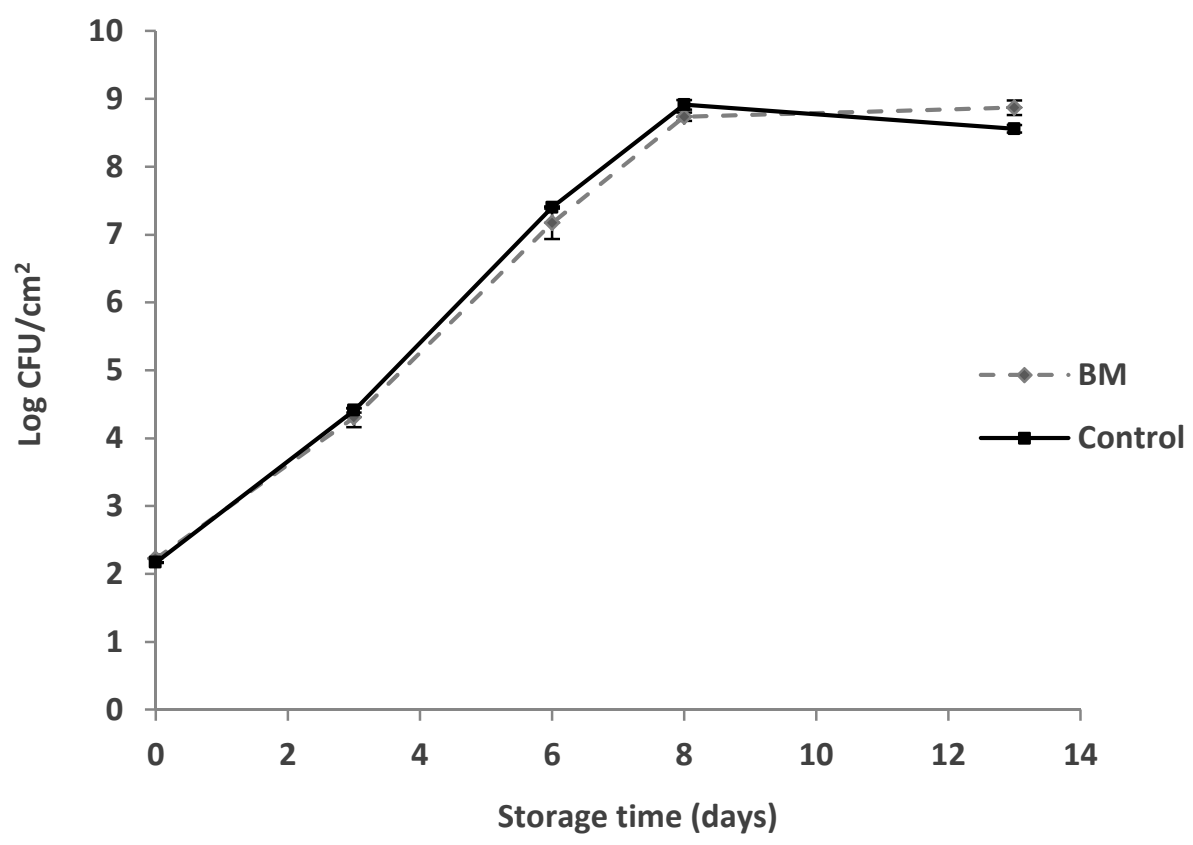

Figure 1.6 Effect of BM on the growth and survival of Listeria innocua on TSANaCl medium stored at $10^{\circ} \mathrm{C}$ for 13 days. Mean values and standard deviation for each time. 


\section{CONCLUSIONS}

icrostructural analysis of starch-buttermilk blend films revealed a reduced compatibility between the starch and milk proteins, leading to phase separation and a heterogeneous structure where lipid droplets can also be observed. Heating the buttermilk implied structural differences and the protein phase interpenetrated the starch matrix when there are $60 \%$ of BM in the film. Incorporation of BM to starch films provoke a significant decrease in film stiffness and resistance to break without notable changes in film stretchability, except for $60 \%$ non-heated BM, when films become more extensible but very soft. BM slightly promotes WVP of the starch films and imparted them a more saturated yellowness, reducing their gloss when not heated, but increasing it when heated. Only films containing heated BM showed antioxidant activity, which is attributed to the active peptides released during thermalhomogenization treatments. Buttermilk did not exhibit antimicrobial activity against Listeria innocua, probably due to the low proportion of antimicrobial compounds or to the difficulties involved in their release into the culture medium. Despite its high protein content, with potential antioxidant or antimicrobial properties, BM is not appropriate to formulate starch film due to the negative effect of the other solids present in the commercial powder on the film properties.

\section{Acknowledgements}

The authors acknowledge the financial support provided by Universitat Politècnica de València (PAID-06-11-2013), Generalitat Valenciana (GV/2013/152), and Ministerio de Educación y Ciencia (Project AGL2010-20694). Olga Moreno Marro also thanks Ministerio de Educación, Cultura y Deporte for a FPU grant. 


\section{REFERENCES}

Affolter, M., Grass, L., Vanrobaeys, F., Casado, B. \& Kussmann, M. (2010). Qualitative and quantitative profiling of the bovine milk fat globule membrane proteome. Journal of Proteomics 73, 1079-1088.

Allen, J. C., \& W. L. Wrieden (1982). Influence of milk proteins on lipid oxidation in aqueous emulsion. I. Casein, whey protein and $\alpha$-lactalbumin. J. Dairy Res. 49:239-248.

ASME B46.1 (1995). Surface texture: surface roughness, waviness and lay. An American National Standard; ASME: New York.

ASTM. (1999). Standard test method for specular gloss. Standard Designation: D523-89. In: Annual Book of American Society for Testing Materials, West Conshohocken, PA, USA.

ASTM. (1995). Standard test methods for water vapor transmission of materials. Standard Designations: E96-95. In: Annual Book of American Society for Testing Materials, West Conshohocken, PA, USA.

Azeredo, H.M.C. (2009). Nanocomposites for food packaging applications. Food Research International 42, 1240-1253.

Baussay, K., Le Bon, C., Nicolai, T., Durand, D., \& Busnel, J. (2004). Influence of the ionic strength on the heat-induced aggregation of the globular protein -lactoglobulin at $\mathrm{pH} 7$. International Journal of Biological Macromolecules, 34, $21 \mathrm{e} 28$.

Carvalho, A.J.F. (2008) Starch: major sources, properties and applications as thermoplastic materials. Monomers, Polymers and Composites from renewable Resources (Ed.: Belgacem, M.N. and Gandini, A.) Elsevier Ltd., p: 321-342.

Colbert, L. B., \& E. A. Decker (1991). Antioxidant activity of an ultrafiltration permeate from acid whey. J. Food Sci. 56:1248-1250.

Cuq, B., Gontard, N.\& Guilbert, S. (1997). Thermoplastic properties of fish myofibrillar proteins: application to biopackaging fabrication. Polymer 38 (16), 4071-4078.

Dickinson, E. \& Stainsby, G. (1982). Colloids in foods. Elsevier Applied Science Publishers. LTD Londres.

Fabra, M.J., Talens, P. \& Chiralt, A. (2009). Microstructure and optical properties of sodium caseinate films containing oleic acid - beeswax mixtures. Food hydrocolloids, 23(3), 676-683

Fabra, M.J., Talens, P. \& Chiralt, A. (2010). Water sorption isotherms and phase transitions of sodium caseinate-lipid films as affected by lipid interactions. Food Hydrocolloids 24, 384-391. 
Famá, L., Rojas, A., Goyanes, S., \& Gerschenson, L. (2005). Mechanical properties of tapioca-starch edible films containing sorbates. LWT - Food Science and Technology, 38 (6), 631-639.

Farnaud, S. \& Evans, R.W. (2003) Lactoferrin-a multifunctional protein with antimicrobial properties. Molecular Immunology 40 395-405.

Gelders, G.G., Vanderstukken, T.C., Goesaert, H., \& Delcour, J.A. (2004). Amylose lipid complexation: a new fractionation method. Carbohydrate Polymers, 56 (4), 447-458.

Gennadios, A., Weller, C.L., \& Gooding, C.H. (1994). Measurement errors in water vapor permeability of highly permeable, hydrophilic edible films. Journal of Food Engineering, 21, 395-409.

Hutchings, J.B. (1999). Food Color and Appearance, $2^{\text {nd }}$ ed. Ed. Aspen Publishers, Inc., Gaithersburg, Maryland, USA.

Jenssen, H. \& Hancock, R.E.W. (2009). Antimicrobial properties of lactoferrin. Biochimie 91 19-29.

Jiménez, A., Fabra, M.J., Talens, P. \& Chiralt, A. (2012). Effect of re-crystallization on tensile, optical and water vapour barrier properties of corn starch films containing fatty acids. Food Hydrocolloids, 26(1), 302-310

Kechichian, V., Ditchfield, C., Veiga-Santos, P. \& Tadini, C.C. (2010). Natural antimicrobial ingredients incorporated in biodegradable films based on cassava starch. LWT-Food Science and Technology 43, 1088-1094.

Kristo, E., Koutsoumanis, Konstaninos P., Biliaderis, \& Costas G. (2008). Thermal, mechanical and water vapor barrier properties of sodium caseinate films containing antimicrobials and their inhibitory action on Listeria monocytogenes. Food Hydrocolloids 22 373-386.

Mathew, S. \& Abraham, T.E. (2008). Characterisation of ferulic acid incorporated starchchitosan blend films. Food Hydrocolloids 22, 826-835.

Madureira, A.R., Pereira, C.I., Gomes, Ana M.P., Pintado, M.E. \& Malcata, F.X. (2007) Bovine whey proteins - Overview on their main biological properties. Food Research International 40 1197-1211.

Maté, J. I., Frankel, E. N., \& Krochta, J. M. (1996). Whey protein isolate edible coating: Effect on the rancidity process of dry roasted peanuts. J. Agric. Food Chem. 44:17361740.

Michalski, M.C., \& Januel, C. (2006). Does homogenization affect the human health properties of cow's milk? Trends in Food Science \& Technology 17, 423-437

Mills, S., Ross, R.P., Hill, C., Fitzgerald, G.F. \& Stanton, C. (2011) Milk intelligence: Mining milk for bioactive substances associated with human health. International Dairy Journal 21 377-401. 
Mishra, B., Leishangthem, G.D., Gill, K., Singh, A.K., Das, S., Singh, K., Xess, I., Dinda, A., Kapil, A., Patro, I. \& Dey S. (2013) A novel antimicrobial peptide derived from modified N-terminal domain of bovine lactoferrin: Design, synthesis, activity against multidrug-resistant bacteria and Candida. Biochimica et Biophysica Acta 1828 677-686.

Ndoye, F.T., Erabit, N., Flick, D. \& Álvarez, G. (2013) In-line characterization of a whey protein aggregation process: Aggregates size and rheological measurements. Journal of Food Engineering 115 73-82.

Nicolai, T., Britten, M. \& Schmitt, C. (2011) -Lactoglobulin and WPI aggregates: Formation, structure and applications. Food Hydrocolloids $251945 \mathrm{e} 1962$.

Pastor, C., Sánchez-González, L., Cháfer, M., Chiralt, A., \& González-Martínez, C. (2010). Physical and antifungal properties of hydroxypropylmethylcellulose based films containing propolis as affected by moisture content. Carbohydrate Polymers, 82, 11741183.

Pelegrine, D.H.G. \& Gasparetto, C.A. (2005). Whey proteins solubility as function of temperature and $\mathrm{pH}$. Lebensm.-Wiss. u.-Technol. 38, 77-80

Pihlanto, A. (2006). Antioxidative peptides derived from milk proteins. International Dairy Journal 16,1306-1314

Pyla, R., Kim, T.J., Silva, J.L. \& Jung, Y.S. (2010). Enhanced antimicrobial activity of starch-based film impregnated with thermally processed tannic acid, a strong antioxidant. International Journal of Food Microbiology 137, 154-160.

Re, R., Pellegrini, N., Proteggente, A., Pannala, A., Yang, M. \& Rice-Evans, C., (1999). Antioxidant activity applying an improved ABTS radical cation decoloration assay. Free Radical Biology and Medicine 26, 1231-1237

Saiah, R., Sreekumar, P.A., Leblanc, N. \& Saiter, J.M. (2009). Structure and thermal stability of thermoplastic films based on wheat flour modified by monoglyceride. Industrial Crops and Products 29, 241-247.

Sánchez-González, L., Cháfer, M., Hernández, M., Chiralt, A. \& González-Martínez, C. (2011) Antimicrobial activity of polysaccharide films containing essential oils. Food Control, 22, 1302-1310.

Sánchez-García, M.D., Giménez, E., \& Lagaron, J.M. (2008). Morphology and barrier properties of solvent cast composites of thermoplastic biopolymers and purified cellulose fibers. Carbohydrate Polymers 71, 235-244.

Satué-Gracia, M. T., Frankel, E. N., Rangavajhyala, N., \& German, J. B. (2000). Lactoferrin in infant formulas: Effect on oxidation. Journal of Agricultural and Food Chemistry, 48, 4984-4990.

Shen, X.L., Wu, J.M., Chen, Y. \& Zhao, G. (2010). Antimicrobial and physical properties of sweet potato starch films incorporated with potassium sorbate or chitosan. Food Hydrocolloids 24, 285-290. 
Stuchell, Y. M. \& Krochta, J. M. (1995). Edible coating on frozen king salmon: Effect of whey protein isolate and acetylated monoglycerides on moisture loss and lipid oxidation. J. Food Sci. 60:28-31.

Talja Riku, A., Harry, H., Roos Yrjö, H. \& Jouppilla, K. (2007) Effect of various polyols and polyol contents on physical and mechanical properties of potato starch-based films. Carbohydrate Polymers, 67, 288-295

Teixera, E. M., Da Róz, A. L., Carvalho, A. J. L. \& Curvelo, A. A. S. (2007) The effect of glycerol/sugar/water and sugar/water mixtures on the plasticization of thermoplastic cassava starch. Carbohydrate Polymers, 69, 619-624

Van der Kraan Marieke, I.A., Groenink, J., Nazmi, K., Verman Enno, C.I., Bolscher Jan, G.M. \& Amerongen Arie, V. (2004) Nieuw. Lactoferrampin: a novel antimicrobial peptide in the N1-domain of bovine lactoferrin. Peptides 25 177-183.

Villalobos, R., Hernández, P., Chanona, J., Gutiérrez-López, G. \& Chiralt, A. (2005) Gloss and transparency of hydroxypropilmethylcellulose films containig surfactants as affected by their microstructure. Food Hydrocolloids, 19, 53-61.

Wakabayashi, H., Matsumoto, H., Hashimoto, K., Teraguchi, S., Takase, M., \& Hayasawa, H. (1999). Inhibition of iron/ascorbateinduced lipid peroxidation by an Nterminal peptide of bovine lactoferrin and its acylated derivatives. Bioscience, Biotechnology and Biochemistry, 63, 955-957

Wiles, D.M. (2005). Oxo-biodegradable polyolefins in packaging. Biodegradable Polymers for industrial applications. Woodhead Publishing Limited.

Wong, P.Y.Y. \& Kitts, D.D. (2001). An iron binding assay to measure activity of known food sequestering agents: studies with buttermilk solids. Food chemistry 72, 245-254.

Wong, P.Y.Y. \& Kitts, D.D. (2003). Chemistry of buttermilk solid antioxidant activity. Journal of Dairy Science 86 (5), 1541-1547.

Zuniga, R. N., Tolkach, A., Kulozik, U., \& Aguilera, J. M. (2010). Kinetics of formation and physicochemical characterization of thermally-induced beta-lactoglobulin aggregates. Journal of Food Science, 75, E261-E268. 


\title{
CHAPTER 2
}

\section{EFFECT OF THE INCORPORATION OF ANTIMICROBIAL/ANTIOXIDANT PROTEINS ON THE PROPERTIES OF POTATO STARCH FILMS}

Olga Moreno*, Lorena Atarés, Amparo Chiralt.

Departamento de Tecnología de Alimentos - Instituto de Ingeniería de Alimentos para el Desarrollo. Universitat Politècnica de València, Camino de Vera s/n 46022 Valencia, Spain

\section{Carbohydrate Polymers 133 (2015) 353-364}

\author{
*Telephone: 0034963877369 Ext. 77369 Fax: 0034963877369 \\ e-mail: olmomar1@upvnet.upv.es
}




\title{
ABSTRACT
}

\begin{abstract}
G lycerol plasticized potato starch films containing bioactive proteins (lactoferrin (LF) and/or lysozyme (LZ), at 0.1 and 0.2 ratio with respect to starch) were obtained by casting method and characterised as to their microstructural, thermal and physical (water content, mechanical, water and oxygen barrier, optical) properties. The bioactive properties, named antioxidant and antimicrobial, of the proteins and the films were also characterized. The incorporation of proteins affected the structural and physical properties of potato starch films, while modifying their thermal behaviour and increasing the glass transition temperature. Both proteins showed a certain degree of compatibility with starch chains through the bond formations (increase in $\mathrm{Tg}$ ), while a part is separated and migrates to the film surface. Their incorporation, especially that of lactoferrin, greatly increased the film's brittleness, regardless of the films water content, although they enhance the water vapour and oxygen barrier properties, whatever the age of the film. Protein also reduced the film's transparency and gloss, while lactoferrin induced colour changes. The thermal degradation of blend films and isolated proteins occurred at temperatures of over $250^{\circ} \mathrm{C}$, which means that blend starch films can be thermoprocessed, according to their thermoplastic properties and following the usual practices of the plastics industries. A synergistic antimicrobial action against E.coli and coliforms was observed when both LZ and LF were simultaneously applied. Both of these exhibited antioxidant capacity.
\end{abstract}

KEYWORDS: edible films, potato starch, lactoferrin, lysozyme, bioactive properties. 


\section{INTRODUCTION}

owadays, the accumulation of non-biodegradable plastics is a paramount environmental concern which still has not been efficiently addressed (Azeredo, 2009). Bioplastics produced from renewable resources are being recognized as a solution to environmental problems concerning waste and dependence on fossil fuels (Byun \& Kim, 2014). Starch is one of the most widely used and promising materials in the bioplastics market due to its biodegradability, availability, renewability and low cost (Wilhelm et al., 2003; Barnett, 2011). Native starch does not have thermoplastic properties; however, with the addition of plasticizers and thermal-shearing processing, native starch gelatinizes and turns into thermoplastic starch (TPS), from which films can be obtained by using both solution casting or thermoprocessing (Zhang et al., 2014).

Biodegradable packaging materials can additionally be carriers of antioxidant and/or antimicrobial agents (Sánchez-García et al., 2008) in order to obtain active packaging products, in which active compounds are released into the food or the surrounding environment (e.g. head space) in the package so as to extend the shelf life of food and to improve its safety and quality properties (Realini \& Marcos, 2014).

Oxidation is a chemical process, slower than microbial spoilage, which lies in a primary quality factor limiting the shelf-life of a wide variety of foods, mainly dry and/or fatty foods. With the aim of avoiding the oxidation damage, edible films and coatings can be used as oxygen barrier layer and vehicle for antioxidant delivery. A trend towards using natural antioxidants instead of synthetic ones exists due to consumer perceptions of the safety and acceptance of such antioxidants compared to synthetics (Lee, 2014). Edible films containing natural antioxidants have been extensively applied to fresh products and dried foods (Das et al., 2013; Gimenez et al., 2011; Han et al., 2008; Lin et al., 2008).

As regards microbial spoilage, the growth of microorganisms is not only detrimental to the organoleptic characteristics of food (such as off-odors and accelerated changes in aroma, color and texture), but also some microorganisms and their toxins may cause food recalls and serious foodborne outbreaks (Corrales et al., 2014). In order to prolong the food shelf-life and maintain product safety, quality and freshness, it is necessary to select adequate materials and packaging technologies, of which biodegradable films 
containing antimicrobials are being extensively studied (Kechichian et al., 2010). The incorporation of active compounds into food packaging increases the efficiency of food preservation (Moreno et al., 2014). Likewise, the use of natural antimicrobials is gradually growing because of the greater consumer awareness of the potential health risks of some synthetic antimicrobials (Gyawali \& Ibrahim, 2014; Moreira et al., 2005).

Lactoferrin and lysozyme could be used for the purposes of conferring active properties to biodegradable films (Jenssen and Hancock, 2009). Lactoferrin (LF) is an iron-binding glycoprotein (approximately $80 \mathrm{KDa}$ ), belonging to the family of transferrin proteins (Farnaud and Evans, 2003; García-Montoya et al., 2012; Jenssen and Hancock, 2009; Pan et al., 2007), which has been reported as an antimicrobial enzyme against a wide array of Gram positive and Gram negative bacteria (Drago, 2006; Pan et al., 2007). The antibacterial action of LF is based on both bacteriostatic and bactericidal mechanisms. The bacteriostatic effect is due to its ability to sequestrate iron making this nutrient unavailable for bacteria (Arnold et al., 1977; Reyes et al., 2005). The bactericidal effect has been attributed to its direct interaction with the bacterial membranes (GarcíaMontoya et al., 2012). Specifically, LF has the ability to damage the outer membrane of Gram negative bacteria directly due to its interaction with lipolisacharide (LPS) (Ellison et al., 1988). The use of Lysozyme (LZ) in antimicrobial packaging applications has been described by several authors (Barbiroli et al., 2012; Gemili et al., 2009, Buonocore et al., 2005). The antimicrobial activity of this protein is based on its ability to break the bonds between $\mathrm{N}$-acetylmuramic acid and $\mathrm{N}$-acetylglucosamine of the peptidoglycan of the cell walls of Gram positive bacteria (Guçbilmez et al., 2007). In order to amplify the antimicrobial spectrum of the lysozyme, some authors have pointed out the possibility of combining it with detergents and chelators which lead to the destabilization of the outer membrane in Gram negative bacteria (Gill \& Holley, 2000; Branen \& Davidson, 2004). In this sense, LF has the ability to enhance the antibacterial activity of $L Z$, due to its interaction with the LPS (García-Montoya et al., 2012; González-Chávez et al., 2009, Sung et al., 2013). Yamauchi (1992) observed a direct interaction between both proteins against Micrococcus luteus, while Suzuki et al. (1989) obtained a greater bacteriostatic effect when both proteins were used in combination. Recently, other authors (Barbiroli et al., 2012) have obtained similar results, reporting a synergistic action against Listeria.

As concerns the antioxidant activity, LF has been pointed out as an natural antioxidant protein (García-Montoya et al., 2012; Joubran et al., 2013; Samarasinghe et al., 2014; Stejins and Hooijdonk, 2000; Wakabayashi et al., 2006). Elias et al. (2008) reported that different alimentary proteins and peptides can interfere with radical reactions, acting as primary or secondary antioxidants. LF could act as a secondary or preventive 
antioxidant, due to its chelation capability of transition metals (e.g. iron and copper), which would retard the oxidation process (Huang et al., 2005). On the other hand, LZ has been reported as capable of suppressing the generation of reactive oxygen species (ROS) (Liu et al., 2006), which confers it with antioxidant activity.

In order to obtain active starch films with adequate functional properties, the effect of incorporating LF, LZ, and their blend, on the structural, thermal and physical properties of starch biodegradable films was analysed. To evaluate the active properties of the films, the antioxidant and antibacterial properties were analyzed in both pure LF and LZ, and their blend, and in the obtained films.

\section{MATERIALS AND METHODS}

\subsection{Raw materials}

Potato starch (PS) with $17.9 \%$ amylose content was supplied by Roquette Laisa Spain, S.A. (Lestrem cedex, France); lyophilized bovine lactoferrin (LF) was provided by ABIAL Tecnología e Innovación S.L. (Santander, Spain) and lysozyme (LZ) by DSM Food Specialties B.V. (Delft, Netherland). Glycerol, magnesium nitrate and phosphorus pentoxide were supplied by Panreac Química S.A. (Castellar de Vallès, Barcelona, Spain). Stock cultures, Escherichia coli (CECT 101) and Listeria innocua (CECT 910), employed for the antimicrobial activity analysis, were supplied by the Spanish Type Culture Collection (CECT, Burjassot, Spain). Tryptone Soy Broth, Agar bacteriological, Buffered peptone water, Plate Count Agar, Palcam Agar and Violet Red Bile Agar were provided by Scharlab, (Barcelona, Spain). $\mathrm{NaCl}$ was purchased from (Panreac, Barcelona, Spain). Acetic Acid glacial and Potassium lodide (KI) were supplied by Panreac Química S.A. (Castellar de Vallès, Barcelona, Spain), lodine by Acros Organics (Geel, Belgium) and 1-Decanol by Alfa Aesar (Karlsruhe, Germany). 


\subsection{Experimental design and film casting}

PS was dispersed in distilled water at $2 \%$ wt., using magnetic stirring for 5 to 10 minutes. These PS dispersions were heated in a thermostatic bath at $99{ }^{\circ} \mathrm{C}$ for 30 minutes and stirred every 5 minutes. After cooling down with running water, glycerol was added (mass ratio of glycerol to PS was $0.25: 1$ ). The dispersions were homogenized with a rotor stator ultraturrax D125 for 4 minutes at 13,500 rpm, and finally were degassed at room temperature by means of a vacuum pump (MZ 2C NT, Vacuubrand $\mathrm{GMBH}+\mathrm{CO}$ KG, Wertheim, Germany). Separately, protein (LF and/or LZ) aqueous dispersions at $10 \%$ wt. were prepared with magnetic stirring for 20 minutes and degassed. Finally, the PS-glycerol dispersion and the protein dispersions were mixed in different proportions through magnetic stirring and degassed. Seven different combinations of PS, LF and LZ were obtained, with 0.1 or $0.2 \mathrm{~g}$ protein per $\mathrm{g}$ PS. Net LZ or LF and 1:1 blend of both were used. Sample codes (two digits) indicate the $\mathrm{g}$ of LF and LZ per $g$ of PS.

Teflon plates (150mm diameter) were used for film casting. The mass of film forming dispersions corresponding to $1.5 \mathrm{~g}$ of solids was cast on each plate. After drying for $48 \mathrm{~h}$ at $45 \% \mathrm{RH}$ and $25{ }^{\circ} \mathrm{C}$, the films were separated from the plates. For the purposes of studying the effect of storage time on the physical properties of the films, the samples were stored, at $25^{\circ} \mathrm{C}$, for 1 or 5 weeks prior to analyses in desiccators at $53 \% \mathrm{RH}$, by using an oversaturated $\mathrm{Mg}\left(\mathrm{NO}_{3}\right)_{2}$ solution. In order to assess the role of moisture content on the mechanical properties of the films, a part of the dried films was also conditioned, for 1 or 5 weeks, at $33 \% \mathrm{RH}$ and $25^{\circ} \mathrm{C}$, by using $\mathrm{MgCl}_{2}$ oversaturated solution.

\subsection{Microstructural characterization}

Cross-section and surface images of the films were obtained by Scanning Electron Microscopy (SEM) using a JEOL $®$ microscope, model JSM-5410. The film samples were previously stored in a desiccator with $\mathrm{P}_{2} \mathrm{O}_{5}$ in order to eliminate film moisture. Film stripes (5x2mm approximately) were cryofractured by immersion in liquid nitrogen and mounted on cupper stubs. After gold coating, the samples were observed using an accelerating voltage of $10 \mathrm{kV}$. 


\subsection{Thermal characterization}

\subsubsection{Thermogravimetric analysis (TGA)}

The thermal behaviour of the conditioned film samples at $53 \% \mathrm{RH}$ was analysed using a thermogravimetric analyzer (TGA/SDTA 851e, Mettler Toledo, Schwarzenbach, Switzerland). Approximately $3 \mathrm{mg}$ of film samples were gradually heated at $10^{\circ} \mathrm{C} / \mathrm{min}$ from room temperature to $600{ }^{\circ} \mathrm{C}$, under nitrogen flow $(50 \mathrm{~mL} / \mathrm{min})$. The initial degradation temperature $\left(T_{0}\right)$, i. e. the temperature at which $5 \%$ mass loss is registered, was recorded. The temperature at which the maximum degradation rate was observed $\left(T_{\max }\right)$, i.e. the temperature of the peak in the first derivative graphs, as well as the percentage of mass loss at the end of the test $\left(600{ }^{\circ} \mathrm{C}\right)$, were also registered. Measurements were run in duplicate.

\subsubsection{Differential scanning calorimetry (DSC)}

Film samples were desiccated with $\mathrm{P}_{2} \mathrm{O}_{5}$ and submitted to DSC analyses. Approximately $10 \mathrm{mg}$ of sample were weighed and sealed into aluminium pans. An empty sample pan was used as reference. Aiming to determine the glass transition temperature of the samples $\left(\mathrm{T}_{\mathrm{g}}\right)$, a first heating scan was done between 0 and $160^{\circ} \mathrm{C}$ at $50^{\circ} \mathrm{C} / \mathrm{min}$ (in order to allow the removal of residual water), followed by a cooling scan to $0{ }^{\circ} \mathrm{C}$ and a second heating scan to $200{ }^{\circ} \mathrm{C}$ at $10^{\circ} \mathrm{C} / \mathrm{min}$. The tests were perfomed with a DSC (TA Instruments, model DSC1 STARe System, Mettler Toledo) with a $20 \mathrm{~mL} / \mathrm{min}$ nitrogen flow. Each sample was analysed in duplicate.

\subsection{Physical characterization}

\subsubsection{Water content}

The moisture content of conditioned film samples (at 33 or $53 \% \mathrm{RH}$ ) was determined using a gravimetric method. Five samples per formulation were considered. Water was eliminated from the samples using a two-step process: they were firstly desiccated in a vacuum oven $\left(60^{\circ} \mathrm{C}-24 \mathrm{~h}\right.$ ), and secondly stored in desiccators with $\mathrm{P}_{2} \mathrm{O}_{5}$ until constant weight was reached. The results were expressed as $\mathrm{g}$ of water per $100 \mathrm{~g}$ of dry film. 


\subsubsection{Mechanical properties}

The mechanical behavior of the films was analyzed using a texture analyser (TA-XTplus, Stable Micro Systems, Surrey, United Kingdom) according to ASTM D882 (2001). Twelve film stripes $(25.4 \mathrm{~mm}$ wide and $100 \mathrm{~mm}$ long) per formulation were tested. Thickness was measured in four positions along the stripe by means of a hand-held digital micrometer (Electronic Digital Micrometer, Comecta S.A., Barcelona, Spain). Film strips were mounted in the tensile grips (A/TG model) and stretched at a rate of 50 $\mathrm{mm} / \mathrm{min}$ until breaking. The elastic modulus (EM (MPa)), tensile strength at break (TS $(\mathrm{MPa}))$ and percentage of elongation at break (\% E) were determined from stressHencky strain curves, obtained from force-deformation data. Films conditioned at $33 \%$ and $53 \% \mathrm{RH}$ and $25^{\circ} \mathrm{C}$ for 1 and 5 weeks were characterized.

\subsubsection{Water vapour and oxygen permeabilities}

The water vapour permeability (WVP) of the film samples was measured with a modification of the ASTM E96-95 (ASTM, 1995) gravimetric method, (McHugh et al., 1993) using Payne permeability cups (Elcometer SPRL, Hermelle/s Argenteau, Belgium) of $3.5 \mathrm{~cm}$ in diameter. Six round samples per formulation were cut, and the thickness was measured in six points per sample (Electronic Digital Micrometer, Comecta S.A., Barcelona, Spain). WVP was determined at $25^{\circ} \mathrm{C}$ and $53-100 \% \mathrm{RH}$ gradient, which was generated by using an oversaturated $\mathrm{Mg}\left(\mathrm{NO}_{3}\right)_{2}$ solution and pure water, respectively. The side of the film which was in contact with air during drying was oriented towards the gas phase at $53 \% \mathrm{RH}$. The cups were weighed every $1.5 \mathrm{~h}$, for $24 \mathrm{~h}$ with an analytical balance (ME36S Sartorius, Alemania). After the steady state was reached, the slope obtained from the weight loss vs. time was used to calculate WVP.

The oxygen permeability (OP) was measured following the standard method (ASTM D3985-05, 2005), by using an Oxtran System (Mocon, Minneapolis, USA). The measurements were obtained at $53 \% \mathrm{RH}$ using $50 \mathrm{~cm}^{2}$ film samples. Oxygen permeability was calculated by dividing the oxygen transmission rate (OTR) by the difference in oxygen partial pressure between the two sides of the film, and multiplying by the average film thickness. At least two replicates per formulation were made. 


\subsubsection{Optical properties: transparency, colour and gloss}

A spectrocolorimeter (CM-3600d, Minolta Co., Tokyo, Japan) was used to obtain the infinite reflectance spectra of the film samples. Measurements were taken on black and white backgrounds. The internal transmittance $\left(T_{i}\right)$ of the films was determined by applying the Kubelka-Munk theory (Hutchings, 1999) for multiple scattering to the reflection spectra, following the methodology described by Pastor et al. (2010). Six samples per formulation were analyzed, and three measurements per sample were taken. The measurements were performed on the side of the film in contact with air during drying.

CIE- $L^{*} a^{*} b^{*}$ coordinates: lightness $\left(\mathrm{L}_{a b}{ }^{*}\right)$, chrome $\left(\mathrm{C}_{a b}{ }^{*}\right)$ and hue $\left(\mathrm{h}_{\mathrm{ab}}{ }^{*}\right)$ of the films were obtained from the surface reflectance spectra using D65 illuminant $/ 10^{\circ}$ observer. The whiteness index (WI) was also calculated according to Atarés et al. (2010).

The gloss was measured on the film side in contact with air during drying, at a $60^{\circ}$ incidence angle, according to the ASTM standard D-523 (ASTM, 1999), using a flat surface gloss meter (Multi-Gloss 268, Minolta Co., Tokyo, Japan). Ten replicates were obtained per formulation. All the results were expressed as gloss units, relative to a highly polished surface of black glass standard with a value near to 100 .

\subsection{Characterization of active properties.}

\subsubsection{Antimicrobial tests}

In order to evaluate the antimicrobial activity of the proteins in the films, stock cultures of Listeria innocua (CECT 910) and Escherichia coli (CECT 101) were used. These were kept frozen $\left(-18^{\circ} \mathrm{C}\right)$ in Tryptone Soy Broth (TSB), supplemented with $30 \%$ of glycerol. To regenerate each culture, a loopful was transferred into $10 \mathrm{~mL}$ of TSB, then the tube was incubated at $37^{\circ} \mathrm{C}$ overnight and $10 \mu \mathrm{L}$ were again transferred into $10 \mathrm{~mL}$ of TSB. The tube was kept at $37^{\circ} \mathrm{C}$ for $24 \mathrm{~h}$ to reach the exponential phase of growth.

\subsubsection{In vitro assays}

The antimicrobial activity of the proteins was analysed following a modification of the method described by Kristo et al. (2008). Pure LF and LZ and their 1:1 wt. ratio blend 
were tested as to their antibacterial activity against Listeria innocua and Escherichia coli. Tryptone Soy Agar (TSA) with $3 \% \mathrm{NaCl}$ was used as a model solid food system (TSA$\mathrm{NaCl}$ ) (Sánchez-González et al., 2011). $10 \mathrm{~mL}$ of TSA-NaCl were poured into sterile petri dishes and left to solidify. Bacteria cultures in exponential phase of growth were adequately diluted for the inoculation of the agar plates in order to obtain $10^{2} \mathrm{CFU} / \mathrm{cm}^{2}$ target inoculum. At that point, $1 \mathrm{~mL}$ of protein dilution (LF, LZ or their blend) was poured into the agar and left to adsorb on the surface under sterile conditions. The protein dilutions were prepared in order to obtain the same surface solid density of protein as that contained in the films with $0,2 \mathrm{~g}$ of protein $/ \mathrm{g}$ of starch $\left(1.17 \mathrm{mg}\right.$ protein $\left./ \mathrm{cm}^{2}\right)$. Inoculated TSA-NaCl petri dishes without protein were used as inoculum control. Plates were then sealed with parafilm to avoid dehydratation and incubated at $10^{\circ} \mathrm{C}$ and $25^{\circ} \mathrm{C}$ for 24 hours. Then, the agar was aseptically removed from the petri dishes and placed in a sterile plastic bag with $90 \mathrm{~mL}$ of buffered peptone water. Homogenization was performed for 2 minutes in a Stomacher blender (Bag Mixer 400, Interscience). Then, serial dilutions were made and poured onto the specific culture media for L.innocua and E.coli, Palcam Agar and Violet Red Bile Agar, respectively. Plates were incubated at $37^{\circ} \mathrm{C}$ for $48 \mathrm{~h}$ before colonies were counted. All the tests were run in triplicate.

The same method was used to analyze the antimicrobial activity of the films containing the active proteins $(0,2 \mathrm{~g} / \mathrm{g}$ of starch; film samples: $0.2-0 ; 0-0.2 ; 0.1-0.1)$, in order to evaluate the effect of their inclusion in the film matrix on their activity. Instead of the protein dilutions, films with the same area were placed on the inoculated TSA-NaCl petri dishes. The film free drying surface (where the highest density of protein was found) was always put in contact with the agar medium. Inoculated petri dishes without film were used as inoculum control, while inoculated dishes coated with the starch film without proteins (sample 0-0) were used as film control. All the tests were also run in triplicate.

\subsubsection{In vivo assays.}

The effectiveness of the antimicrobial ability of the films in a real food system was tested in minced pork meat, which was obtained from a local supermarket and was processed immediately after arriving at the laboratory. The meat was ground with a mincer (Severin Elektrogeräte $\mathrm{GmbH}$, Sundern, Germany) and amounts, $10 \mathrm{~g}$ in weight, were molded by using petri dishes to obtain the test samples. Then, the surface of both sides of the samples was coated with the films with $0.2 \mathrm{~g}$ protein/g starch (samples 0.2-0;0-0.2; 0.1 0.1 ). Non-coated samples and samples coated with the formulation without protein $(0-0)$ 
were used as controls. All the samples were stored at $10^{\circ} \mathrm{C}$ for 14 days; meanwhile, total aerobic and coliforms counts were obtained. Each sample was aseptically obtained and homogenized in a Stomacher blender (Bag Mixer 400, Interscience) with $90 \mathrm{~mL}$ of Buffered peptone water for $2 \mathrm{~min}$. Then, serial dilutions were made and plated out. Total aerobic counts were determined in Plate Count Agar incubated at $30^{\circ} \mathrm{C}$ for $72 \mathrm{~h}$, while coliforms were determined in Violet Red Bile Agar incubated at $37^{\circ} \mathrm{C}$ for $48 \mathrm{~h}$. All the tests were run in triplicate.

\subsubsection{Antioxidant tests}

\subsubsection{ABTS radical scavenging assay}

The antioxidant capacity of LF, LZ, and their $1: 1$ wt. ratio blend was determined through a spectrophotometric method, as described by Re et al. (1999). The objective of this method is to compare the antioxidant activity of the analyzed substance with that of an antioxidant standard, trolox (6-hydroxy-2,5,7,8-tetramethylchroman-2-carboxylic acid), a vitamin E analogue.

ABTS (2,2'-azino-bis[3-ethylbenzothiazoline-6-sulphonic acid]) was dissolved in water to a concentration of $7 \mathrm{mM}$, and allowed to react with a $2.45 \mathrm{mM}$ potassium persulfate solution (final concentrations) for $16 \mathrm{~h}$ in the dark. ABTS radical cation (ABTS ${ }^{-+}$), a blue chromophore, was produced during that period. The $\mathrm{ABTS}^{-+}$solution was diluted with ethanol until an initial absorbance of $0.70( \pm 0.02)$ at $734 \mathrm{~nm}\left(\mathrm{~A}_{0}\right) .10 \mu$ of the test solution was added to $990 \mu \mathrm{L}$ of this solution, and the percentage of absorbance reduction at 6 minutes was registered. All absorbance measurements were taken with a Beckman Coulter DU 730 spectrophotometer, using ethanol as blank. In order to obtain the test solutions, both LF and LZ, as well as their blend, were completely dissolved at $5 \%$ in bidistilled water while stirring at $250 \mathrm{rpm}$ for $16 \mathrm{~h}$. All tests were performed in triplicate.

A calibration curve ( $\%$ absorbance reduction vs. concentration of Trolox) was obtained with different dilutions $(0 \mathrm{mg} / \mathrm{L}$ to $50 \mathrm{mg} / \mathrm{L}$ ) of trolox as standard antioxidant agent. The Trolox equivalent antioxidant capacity (TEAC) of the proteins was defined as the concentration ( $\mathrm{g}$ protein/L) producing the same perceptual absorbance reduction as $1 \mathrm{mM}$ Trolox. 


\subsubsection{Peroxide value (PV)}

The antioxidant ability of the films containing $0.2 \mathrm{~g}$ protein/g starch (samples 0.2-0;0-0.2; 0.1-0.1) was tested on a real food system, pure fresh fat (lard), which was purchased in a local market and kept in refrigeration until the experiment was started (no more than 24 h). Inert glass cups ( $36.5 \mathrm{~mm}$ diameter and $6.6 \mathrm{~mm}$ depth) were totally filled with fat and compressed to ensure the total absence of air bubbles. At this point, each cup surface was completely covered with a film disk. The film free drying surface (where the highest density of protein was found) was always put in contact with the lard. Non-covered cups and cups covered with film without protein (0-0) were used as controls. All the samples were stored at $40{ }^{\circ} \mathrm{C}$ and $53 \% \mathrm{RH}$ for 190 days. The extent of fat oxidation was evaluated throughout the storage by obtaining the peroxide value (PV). An automatic titrator was employed to perform the measurements (Titrando, Metrohm Ion Analysis, Switzerland). With this aim, between $1 \mathrm{~g}$ and $2 \mathrm{~g}$ of lard was dissolved in $10 \mathrm{~mL}$ of solvent (glacial acetic acid and 1-decanol containing 10-15 mg iodine, in a 3:2 mass ratio) and blended with $200 \mu \mathrm{L}$ of an oversaturated $\mathrm{KI}$ solution. The mixture was thoroughly mixed and kept in the dark for $1 \mathrm{~min}$. Then, $50 \mathrm{~mL}$ of distilled water was added and the solution was titrated with $0.01 \mathrm{M}$ or $0.001 \mathrm{M} \mathrm{Na}_{2} \mathrm{~S}_{2} \mathrm{O}_{3}$, depending on the $\mathrm{PV}$ predicted. Prior to the test, a blank value of solvent was obtained following the procedure mentioned above, without the addition of lard. PV was expressed as mequivalents of oxygen per kilogram of pork fat. All the analyses were performed in triplicate.

\subsection{Statistical analysis}

The statistical analysis of the data was performed through analysis of variance (ANOVA) using Statgraphics Centurion XVI. II. Fisher's least significant difference (LSD) procedure was used. 


\section{RESULTS AND DISCUSSION}

\subsection{Microstructural characterization}

Figure 2.1 shows the SEM images of PS films (cross section and film surface) while Figure 2.2 and Figure 2.3 show, respectively, SEM images of the cross section of the blend films and their surface, after 1 week of storage. The films with no protein (Figure 2.1) exhibited a homogeneous, compact structure without pores. Protein addition gave rise to more heterogeneous structures, as a result of the partial incompatibility of both proteins and starch. On blend film surfaces (Figure 2.3), globular formations can be observed which can be attributed to protein separation from the starch matrix, in agreement with a lack of complete miscibility of the polymers. The limited miscibility favoured protein creaming during the film drying, due to their lower density, which implied a heterogeneous distribution of protein through the film matrix.

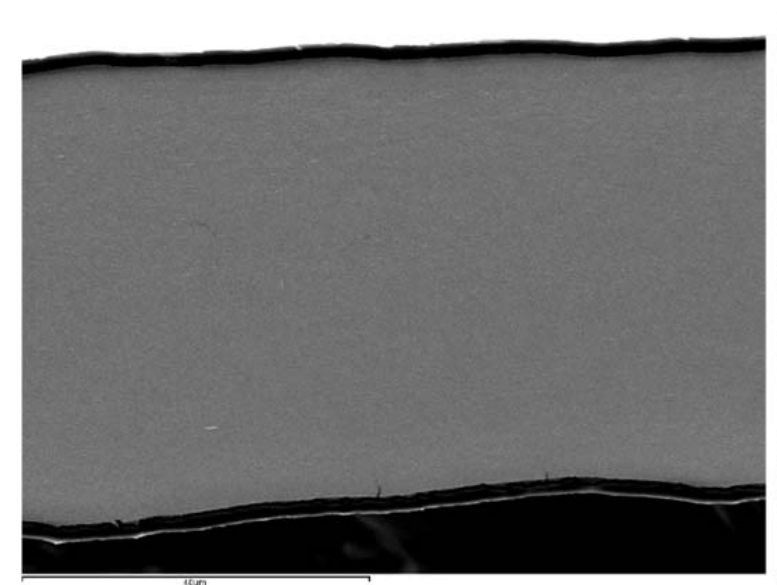

Cross section

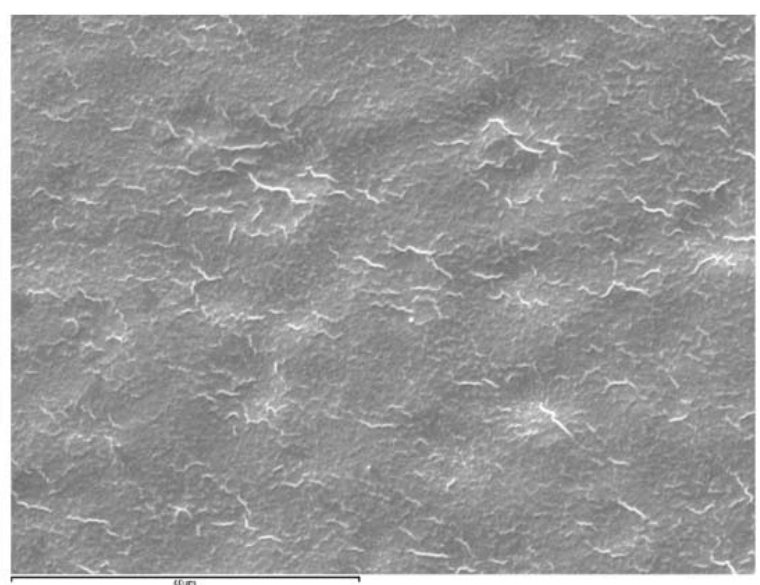

Surface

Figure 2.1 SEM images of the cross section and surface of dried net starch films (0:0 sample).

Likewise, the fact that a protein fraction remained dispersed in the PS matrix produced discontinuities, which generated micro-fractures in the film structure. This fragility was mainly noticeable in films with LF, particularly in the films with the highest LF proportion 
(sample 0.2-0), which suggests that PS is more compatible with LZ than LF. With the same protein ratio, films containing LZ or LZ-LF blends appeared more homogenous without discontinuities in the matrix. Differences in the proteins' compatibilities could be due to differences in their molecular weight, namely $80 \mathrm{kDa}$ for LF (Barbiroli et al., 2012) and $14.4 \mathrm{kDa}$ for LZ (Corradini et al., 2013) as well as their aminoacid sequence (primary structure) and the secondary and the tertiary structures, which can play a key role in the chemical interactions with the starch matrix. These differing molecular structures would, in turn, affect the availability of functional groups able to establish favourable interactions with the starch chains.

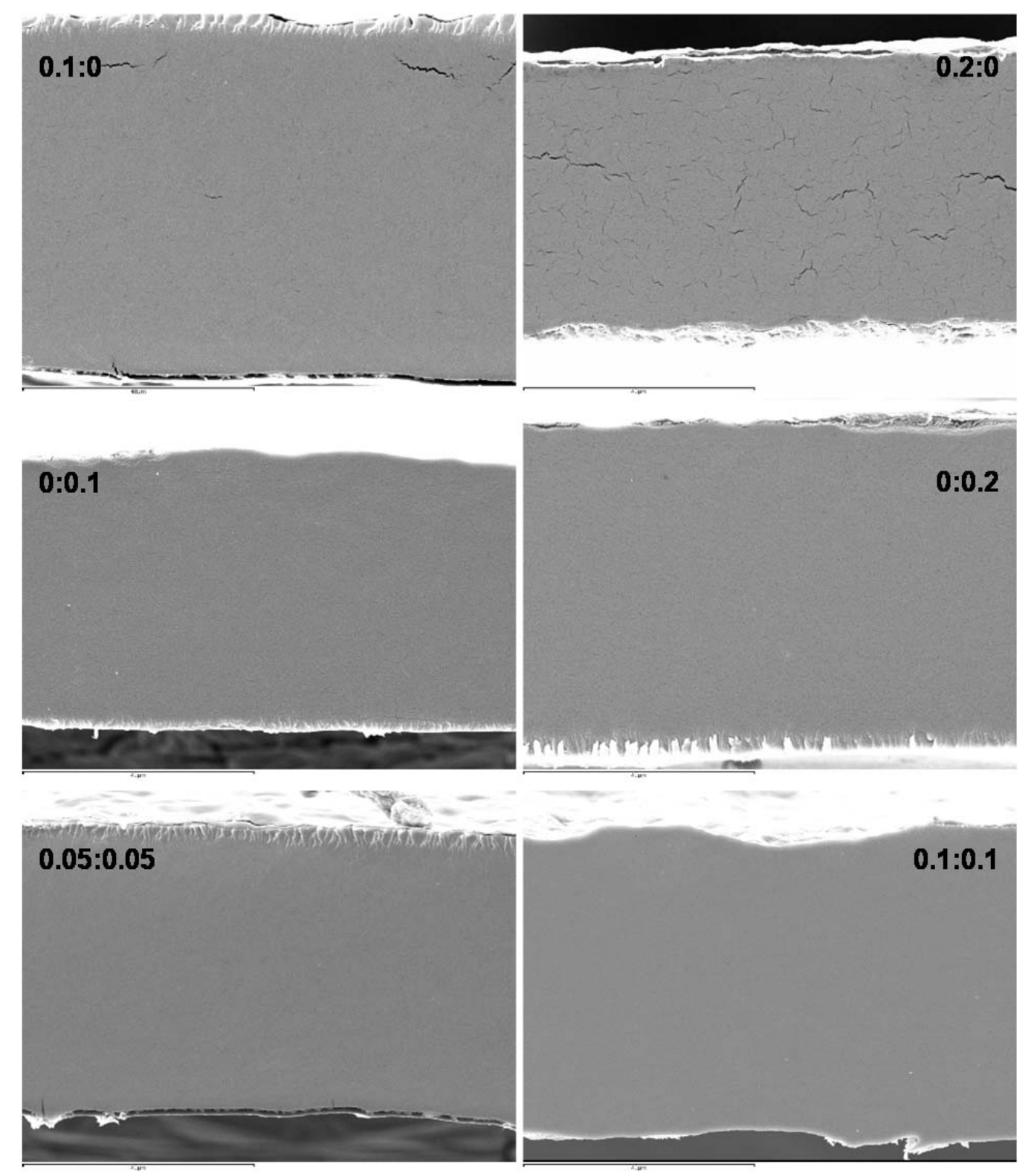

Figure 2.2 SEM images of the cross section of the dried films. Sample codes refer to the mass ratio of LF (first digit) and LZ (second digit) with respect to PS. 

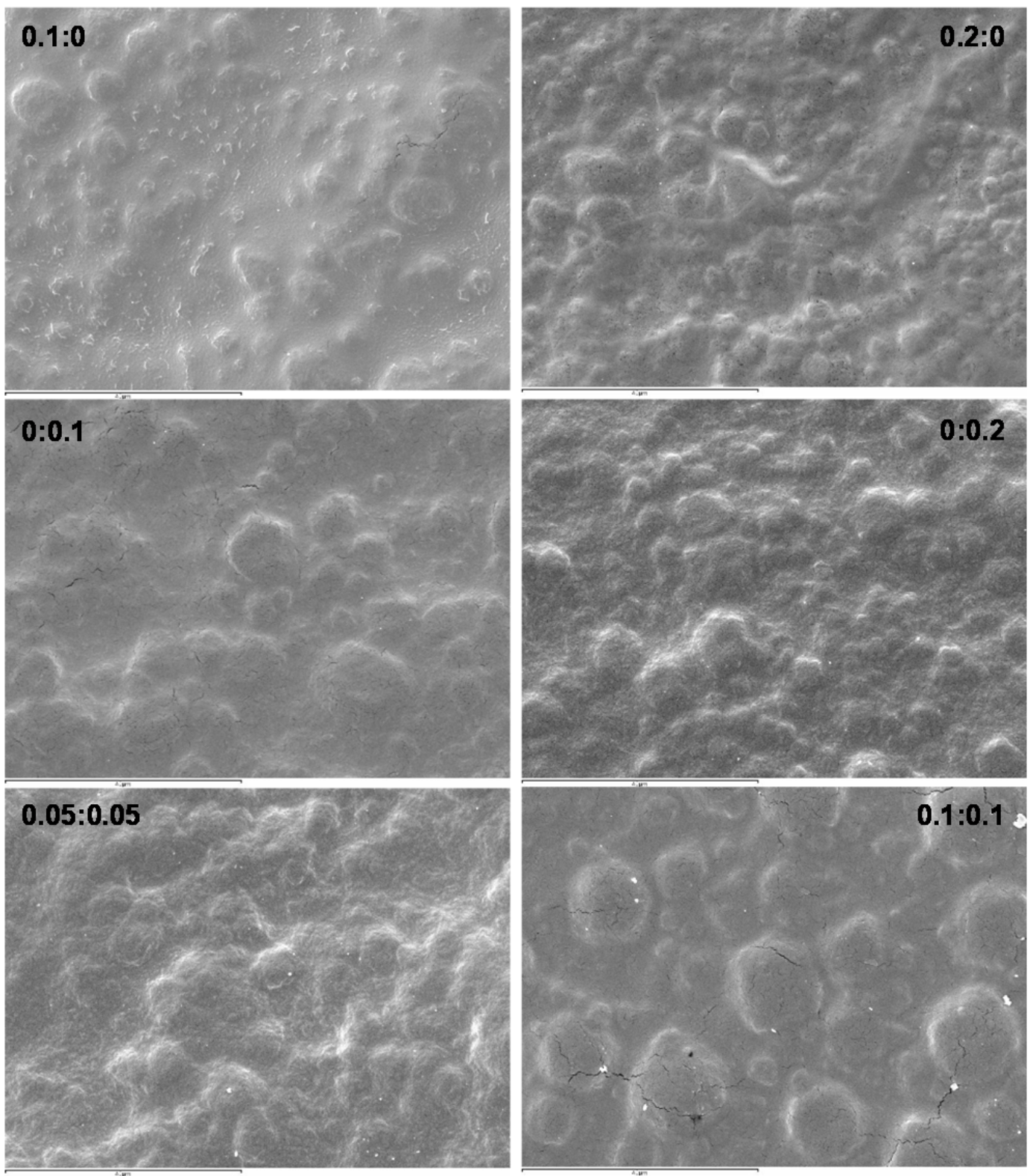

Figure 2.3 SEM images of the surface of the dried films. Sample codes refer to the mass ratio of LF (first digit) and LZ (second digit) with respect to PS.

\subsection{Thermal characterization}

Figure 2.4a shows the thermal degradation curves, determined by TGA, of the different films and pure proteins, where the influence of proteins (type and content) in the starchbased films' thermal behavior can be appreciated. A first weight loss step with a peak temperature near $100{ }^{\circ} \mathrm{C}$ was observed in all cases, due to the initial dehydration of the films. Table 2.1 shows the values of the initial degradation temperature $\left(T_{0}\right)$, maximum 
degradation rate temperature ( $T_{\max }$, in Figure 2.4b) and the percentage mass loss at the end of the TGA test $\left(600^{\circ} \mathrm{C}\right)$ for both the pure proteins and films.

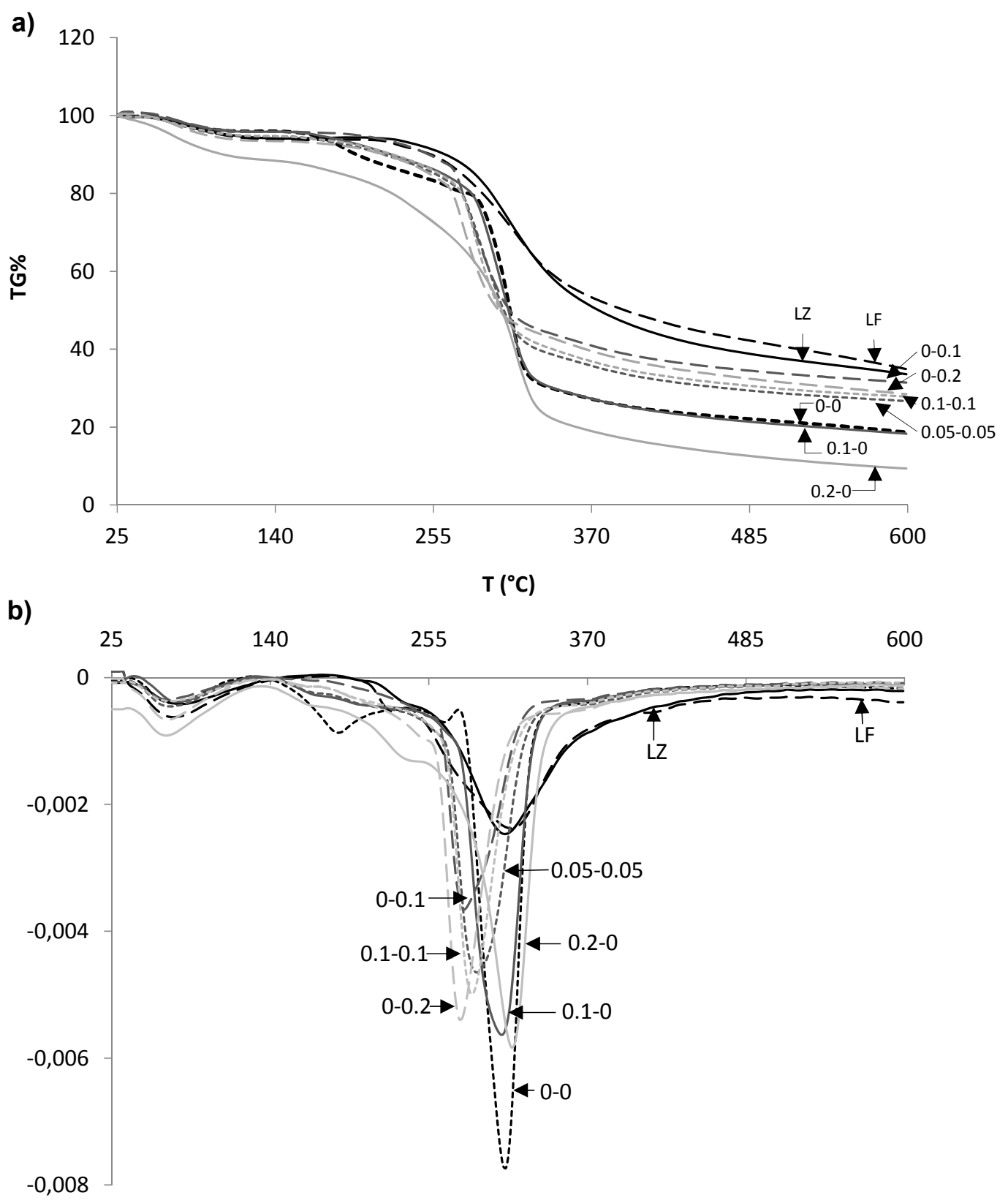

Figure 2.4. a) Thermogravimetric curves for the film samples and pure proteins ( $L Z$ and LF) and b) first derivative from TGA curves for the film samples and pure proteins (LF and LZ). Sample codes refer to the mass ratio of LF (first digit) and LZ (second digit) with respect to PS. 
The T0 and Tmax values of the starch films (sample 0-0) were $282{ }^{\circ} \mathrm{C}$ and $310{ }^{\circ} \mathrm{C}$, respectively, similar to previous reported values for potato, wheat and maize starch films (He et al., 2012; Soares et al., 2005). These values were significantly higher $(p<0.05)$ than that of the pure proteins (Table 2.1), which showed a similar degradation behaviour, although LF degraded slightly faster according to its lower molecular weight. Protein incorporation into starch films provoked significant changes in the degradation pattern of the films, depending on the protein type and ratio, always decreasing the $T_{0}$ and $T_{\max }$ values, but in some cases reducing the percentage mass loss.

Table 2.1 Thermal properties of the films obtained by TGA $\left(T_{0}, T_{\max }, \%\right.$ Mass loss at 600 $\left.{ }^{\circ} \mathrm{C}\right)$ and $\mathrm{DSC}(\mathrm{Tg})$.

\begin{tabular}{ccccc}
\hline Film sample & $\mathrm{T}_{0}\left({ }^{\circ} \mathbf{C}\right)$ & $\mathrm{T}_{\max }\left({ }^{\circ} \mathrm{C}\right)$ & \%Mass loss & $\mathrm{T}_{\mathbf{g}}\left({ }^{\circ} \mathrm{C}\right)$ \\
\hline $\mathbf{0 - 0}$ & $282.1 \pm 0,4^{\mathrm{e}}$ & $310.3 \pm 0.2^{\mathrm{d}}$ & $80.4 \pm 1.3^{\mathrm{e}}$ & $125.9 \pm 0.2^{\mathrm{a}}$ \\
\hline $\mathbf{0 . 1 - 0}$ & $279.1 \pm 0.4^{\mathrm{e}}$ & $308.1 \pm 0.4^{\mathrm{d}}$ & $77 \pm 7^{\mathrm{de}}$ & $129.62 \pm 1.07^{\mathrm{b}}$ \\
$\mathbf{0}-\mathbf{0 . 1}$ & $265.1 \pm 0.5^{\mathrm{c}}$ & $281.1 \pm 0.7^{\mathrm{a}}$ & $67.4 \pm 1.7^{\mathrm{abc}}$ & $153.2 \pm 0.9^{\mathrm{c}}$ \\
\hline $\mathbf{0 . 0 5 - 0 . 0 5}$ & $270.0 \pm 0.3^{\mathrm{d}}$ & $290.8 \pm 0.2^{\mathrm{c}}$ & $73.1 \pm 0.2^{\mathrm{cd}}$ & $138.6 \pm 0.7^{\mathrm{c}}$ \\
\hline $\mathbf{0 . 2 - 0}$ & $283 \pm 5^{\mathrm{e}}$ & $314 \pm 2^{\mathrm{e}}$ & $88 \pm 4^{\dagger}$ & $138.9 \pm 1.1^{\mathrm{c}}$ \\
\hline $\mathbf{0 - 0 . 2}$ & $263.0 \pm 0.9^{\mathrm{bc}}$ & $278.3 \pm 0.5^{\mathrm{a}}$ & $71.1 \pm 0.6^{\mathrm{abcd}}$ & $161.8 \pm 0.2^{\mathrm{d}}$ \\
\hline $\mathbf{0 . 1 - 0 . 1}$ & $269.0 \pm 0.3^{\mathrm{d}}$ & $286.1 \pm 0.4^{\mathrm{b}}$ & $72.3 \pm 0.2^{\mathrm{bcd}}$ & $154.6 \pm 1.5^{\mathrm{c}}$ \\
\hline LF & $248.4 \pm 0.3^{\mathrm{a}}$ & $317 \pm 4^{\mathrm{e}}$ & $65.25 \pm 0.19^{\mathrm{a}}$ & - \\
\hline LZ & $259.4 \pm 0.8^{\mathrm{b}}$ & $309.2 \pm 0.5^{\mathrm{d}}$ & $66.36 \pm 0.09^{\mathrm{ab}}$ & - \\
\hline
\end{tabular}

Different letters $(a, b, c, d, e)$ in the same column indicate significant differences among the different formulations $(p<0.05)$.

Sample codes refer to the mass ratio of LF (first digit) and LZ (second digit) with respect to PS.

It is remarkable that, whereas films with 0.1 of LF show degradation curve which practically overlaps with that of starch films, samples with $0.2 \mathrm{LF}$ showed the highest and fastest thermal degradation. Nevertheless, LZ or LZ-LF blends slightly accelerated the thermal degradation of the starch films, but reduced the total mass loss with respect to pure starch or starch-LF films. In this sense, it is remarkable that residual mass loss was greater for pure proteins than for starch films and that starch films containing $L Z$ (pure or blended with LF) showed an intermediate residual mass between net starch and proteins, in contrast with films containing only LF which exhibit higher mass degradation. This suggests that degradation compounds are different depending on the presence of protein and its type, thus also pointing out to the different starch-protein interactions in each case, as deduced from the microstructural observations. Hydrogen bonds between hydroxyl groups of starch and amino group of the protein chains can occur to different 
extent depending on the protein conformation in the blend. In fact, helical conformation of amylose could entrap different segments of the proteins, as occurs with other organic compounds, in a selective way.

Table 2. 1 also shows the values of the glass transition temperature ( $\mathrm{Tg}$ ) of the films. The Tg values of potato starch films without protein were similar to previously reported values for potato starch (Farahnaky et al., 2009). As proteins were incorporated into the film, a significant increase $(p<0.05)$ of $\mathrm{Tg}$ was found. This increase was promoted when the protein ratio increased and was more marked for films with $L Z$. This suggests that molecular interactions between the starch and the protein chains occurred in the films to a different extent depending on the kind of protein and the ratio. Likewise, the increase indicates that the amorphous starch region behaves with a higher mean molecular weight, which could be explained through the establishment of protein-amylose or amylopectin bonds forming starch-protein complexes. As commented on in section 3.1, LZ seemed to interact with PS to a greater extent than LF, thus leading to the highest complexation degree and, thereby, a greater Tg increase. At both protein:starch ratios, the films with the two proteins showed Tg values between those of films with only one protein. This behaviour points to a partial miscibility of both proteins with starch chains, through complex formation with a higher mean molecular weight than starch chains. This was more notable for LZ, in agreement with a higher protein compatibility with starch.

\subsection{Physical characterization}

\subsubsection{Thickness, water content and mechanical properties}

The thickness of the obtained films ranged between 60 and $80 \mu \mathrm{m}$ (results not shown). The protein addition led to thicker films, coherently with the protein proportion with respect to PS. This indicates that the packing of starch chains was partially limited by the presence of protein in the films probably due to the induced changes in the chain interactions.

Figure 2.5 shows stress-strain curves for the films stored for 1 week at 33 and $53 \%$ relative humidity. Protein incorporation greatly reduced the films' stretchability, even when conditioned at $53 \% \mathrm{RH}$, when net starch films showed a notable extensibility due to the increase in water content and its plasticization effect. This was not observed for

protein-containing films, which must be attributed to the discontinuities introduced in the 
starch matrix which increased its brittleness and to the anti-plasticizing role of the proteins ( $\mathrm{Tg}$ increase) in the starch blend.

33\% RH 1 week storage

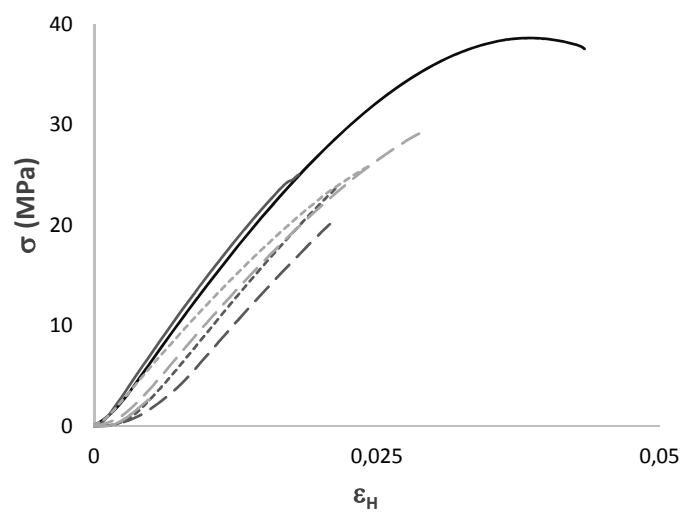

53\% RH 1 week storage

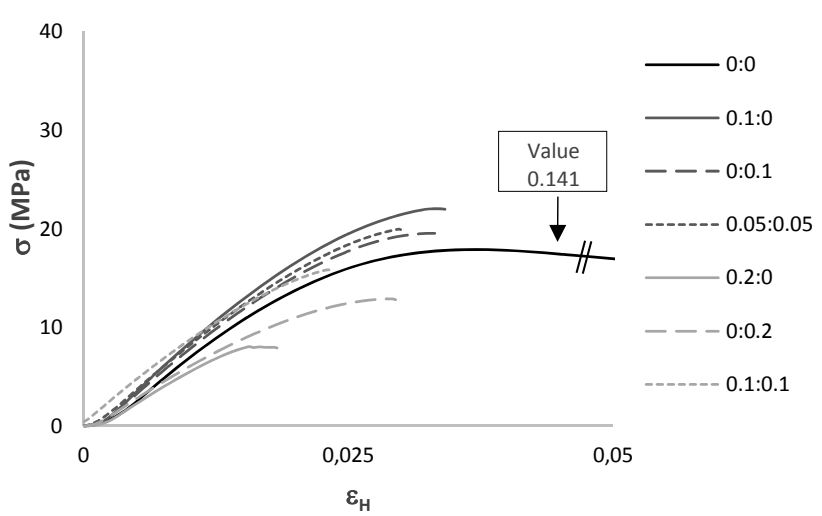

Figure 2.5 Stress - strain curves of the films conditioned for 1 week at $33 \%$ and $53 \%$ $\mathrm{RH}$. Sample code refers to mass ratio of LF (first digit) and LZ (second digit) with respect to PS.

Figure 2.6 shows the values of the mechanical parameters and moisture content of all the studied films conditioned for 1 and 5 weeks at $30 \%$ and $53 \% \mathrm{RH}$. The elasticity modulus (EM (MPa)), is related with the stiffness of the film; the tensile strength (TS (MPa)) corresponds to the resistance to fracture and the deformation percentage at break (\% E) describes the stretchability of the films. Films showed 4 levels of moisture content depending on the time and $\mathrm{RH}$ of conditioning. These levels ranged between 5 and $12 \mathrm{~g}$ water per $100 \mathrm{~g}$ of dried film and, in general, increased for a determined $\mathrm{RH}$ level throughout the conditioning time, thus indicating that after 1 storage week, the equilibrium moisture content was not reached. Nevertheless, it is remarkable that, whereas the moisture content of net starch films hardly changed during storage time, that of films containing proteins increased in every case, which suggests that water uptake in protein-containing films was slower, so, these films took longer to reach the near-equilibrium value. At $33 \% \mathrm{RH}$, films containing protein blends gained significantly greater water content than those containing only LF or LZ. Both moisture content and film composition affected the mechanical response of the films. 

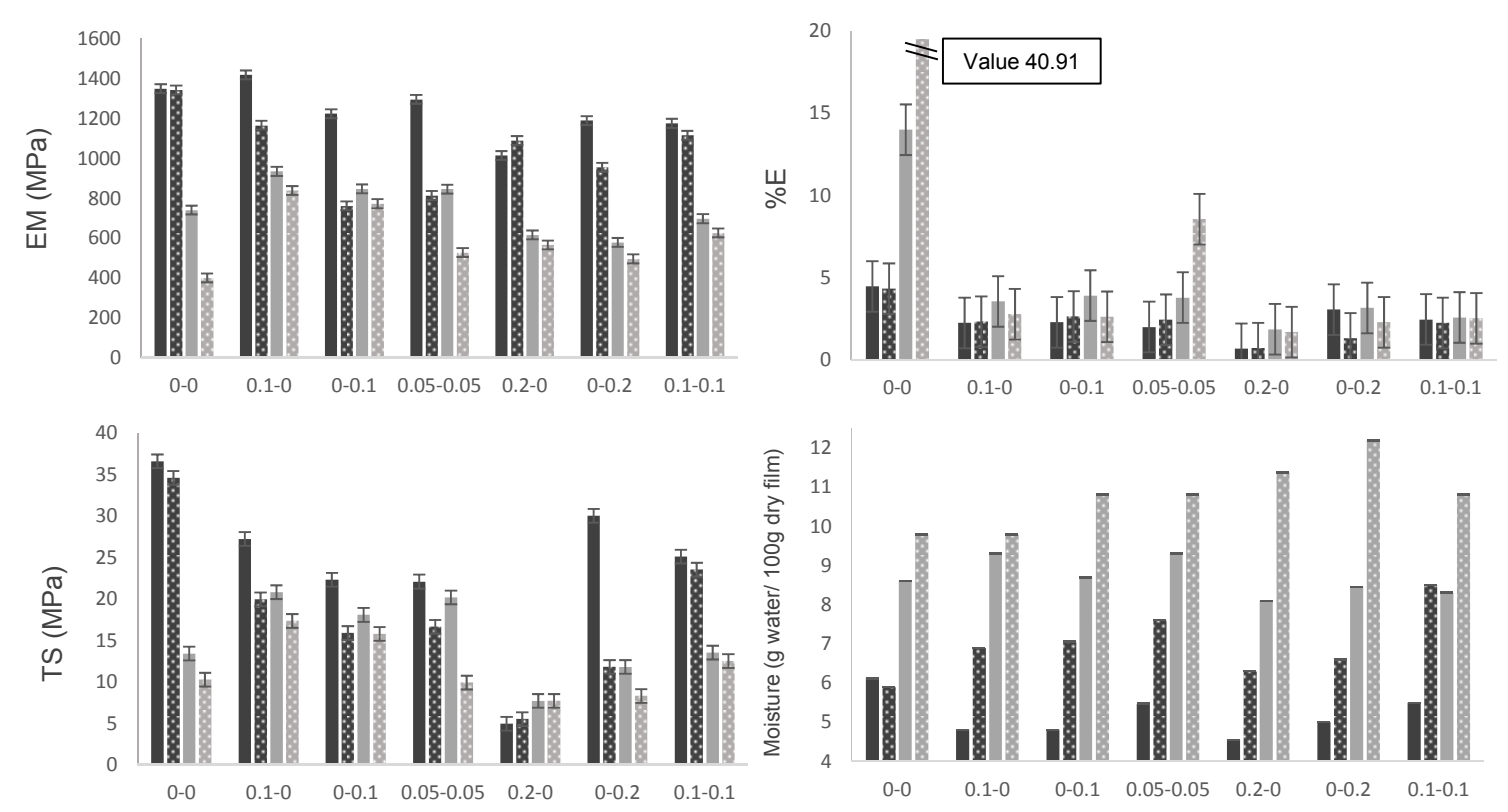

- $30 \%$ RH 1 week $\quad \mathbf{3} 30 \%$ RH 5 weeks

- $45 \%$ RH 1 week $\mathbf{9} 45 \%$ RH 5 weeks

Figure 2.6 Values of the mechanical parameters (elastic modulus -EM (MPa)- tensile strength -TS (MPa)- and deformation - \%E- at break) and moisture content of the films conditioned for 1 and 5 weeks at $33 \%$ and $53 \% \mathrm{RH}$ and $25^{\circ} \mathrm{C}$. Sample codes refer to the mass ratio of LF (first digit) and LZ (second digit) with respect to PS. Mean values and 95\% LSD intervals.

Water uptake provoked a significant decrease in EM and TS of net starch films while film stretchability was enhanced. This expected behaviour, associated with the water plasticization effect, has previously been described for corn starch films containing $25 \%$ glycerol, establishing the critical water content for an effective water plasticization at about $9 \%$ (Jiménez et al. 2013). In films containing proteins, water plasticization also occurred, thus decreasing EM and TS when moisture content rose, but did not suppose a notable increase in the elongation at break, which showed very low values for all moisture contents in every film. Only the film sample 0.1-0.1 with the highest moisture content showed a significantly higher elongation at break, as compared with the other films with proteins. Likewise, films with 0.2 LF were especially brittle, showing the lowest values of TS and \% E, regardless of their moisture content. This behaviour suggests that, although starch matrix was plasticised in all cases, the overall weakening of the starch network cohesion forces due to the presence of protein chains, and the development of specific molecular interactions with the starch molecules, limits the ability of the matrix to stretch, breaking at very low deformation values. The highest ratio of LF provoked the poorest mechanical response, which is coherent with its lower compatibility 
with starch, as deduced from structural and thermal analyses. The effect of storage time could not be analysed independently because of the overlapped effect of the moisture content increase. Other authors described film hardening and an increased in the film brittleness throughout storage time of starch films, which was attributed to the progressive starch chain aggregation or crystallization during storage (Jiménez et al. 2012; Cano et al. 2014).

\subsubsection{Water vapour and oxygen permeabilities}

The water vapour permeability (WVP) of the films after 1 and 5 weeks of storage is reported in Table 2.2. This parameter is closely linked to the films' ability to reduce the water vapour diffusivity when applied to food products, and accordingly it should be as low as possible (Ma et al., 2008). The WVP of films with net starch (sample 0-0) was in the order of those previously reported by Han et al., 2006, Ma et al., 2008, Jiménez et al., 2012 and Cano et al. 2014 for different starch films. WVP was slightly reduced when proteins were added to the films, according to their ratio. This improvement in the water vapour barrier could be due to two combined effects: the specific interactions between the starch and the proteins, which implied a greater Tg of the amorphous matrix and the formation of a surface protein layer, as observed by SEM, on the top of the film (Figure 3). WVP values of some protein films are lower than those of starch films (Monedero et al., 2010), which, in turn, can contribute to modify barrier properties of blend films. No significant differences $(p>0.05)$ were observed in WVP values due to the storage time, despite the abovementioned increase in the moisture content of the films. So, the small changes in water content in the films did not notably affect their water vapour barrier properties.

The oxygen permeability (OP) of the films is also reported in Table 2. OP values of net starch film were similar to those previously reported by Cano et al., (2014) for potato starch films, after both 1 and 5 storage weeks. They also observed a decrease in OP after storage time, which was attributed to the structural changes in the starch matrix, such as the progressive chain aggregations, that enhance the oxygen barrier properties, by limiting the mass transport of gas molecules. The protein addition led to a decrease in OP values in the films, with no significant changes due to the storage time. This behaviour can be explained in terms of the formation of starch-protein bonds, as commented on in section 3.1, which increased the effective size of the polymer chains, thus being more effective at limiting mass transfer processes. Likewise, the absence of 
changes in OP of the protein-containing films throughout time indicates that structural changes in starch matrix could be limited by protein interactions. No notable differences in oxygen barrier properties due to the kind or ratio of proteins were observed.

Table 2.2 Values of the water vapor permeability (WVP) and oxygen permeability (OP) for films conditioned at $53 \% \mathrm{RH}$ and $25^{\circ} \mathrm{C}$ for 1 and 5 weeks.

\begin{tabular}{|c|c|c|c|c|c|}
\hline \multirow{2}{*}{\multicolumn{2}{|c|}{ Samples }} & \multicolumn{2}{|c|}{ WVP $\times 10^{7}\left(\mathrm{~g} \cdot \mathrm{mm} / \mathrm{kPa} \cdot \mathrm{h} \cdot \mathrm{m}^{2}\right)$} & \multicolumn{2}{|c|}{$\begin{array}{c}\text { OP } \\
\left(10^{-14} \mathrm{~cm}^{3} / \mathrm{m} \mathrm{s} \mathrm{Pa}\right)\end{array}$} \\
\hline & & $1 \mathrm{w}$ & $5 \mathrm{w}$ & $1 \mathrm{w}$ & $5 \mathrm{w}$ \\
\hline \multirow{7}{*}{ Films } & $0-0$ & $6.7 \pm 0.3^{\mathrm{C}, 1}$ & $7.5 \pm 0.8^{\mathrm{d}, 1}$ & $15.7 \pm 1.0^{\mathrm{c}, 2}$ & $8.64 \pm 0.09^{a, 1}$ \\
\hline & $0.1-0$ & $6.4 \pm 0.16^{b c, 1}$ & $6.7 \pm 0.4^{\mathrm{cd}, 1}$ & $13 \pm 3^{\mathrm{abc}, 1}$ & $10 \pm 3^{a, 1}$ \\
\hline & $0-0.1$ & $6.1 \pm 0.3^{b, 1}$ & $5.8 \pm 0.3^{\mathrm{abc}, 1}$ & $14.0 \pm 0.3^{b c, 1}$ & $11 \pm 1^{a, 1}$ \\
\hline & $0.05-0.05$ & $6.4 \pm 0.4^{\mathrm{bc}, 1}$ & $5.9 \pm 0.3^{a b c, 1}$ & $11.83 \pm 0.17^{\mathrm{ab}, 1}$ & $10 \pm 2^{a, 1}$ \\
\hline & $0.2-0$ & $5.66 \pm 0.14^{a, 1}$ & $6.4 \pm 1.1^{b c, 1}$ & $10 \pm 1^{\mathrm{a}, 1}$ & $9.50 \pm 0.16^{a, 1}$ \\
\hline & $0-0.2$ & $5.62 \pm 0.11^{a, 1}$ & $5.7 \pm 0.3^{\mathrm{ab}, 1}$ & $12 \pm 2^{\mathrm{ab}, 1}$ & $9.787 \pm 0.014^{a, 1}$ \\
\hline & $0.1-0.1$ & $6.49 \pm 0.17^{\mathrm{c}, 2}$ & $5.6 \pm 0.3^{\mathrm{a}, 1}$ & $10 \pm 1^{a, 1}$ & $9.058 \pm 0.119^{a, 1}$ \\
\hline
\end{tabular}

Different letters $(a, b, c)$ in the same column indicate significant differences among the different formulations for the same storage time $(p<0.05)$.

Different numbers $(1,2)$ in the same row indicate significant differences between both storage times for the same formulation $(p<0.05)$.

Sample codes refer to the mass ratio of LF (first digit) and LZ (second digit) with respect to PS.

\subsubsection{Optical properties: transparency, colour and gloss}

Table 2.3 shows the corresponding colour parameters (lightness, chroma, and hue), the gloss values at $60^{\circ}$, and the internal transmittance (Ti) at $430 \mathrm{~nm}$, as an indicator of their transparency, for the different films conditioned for both 1 and 5 weeks. Protein incorporation provoked a statistically significant reduction $(p<0.05)$ in the film transparency (Ti values) at $430 \mathrm{~nm}$. The most relevant reduction was found for films with LF, due to the selective light absorption of LF components. This agrees with the greater structural heterogeneity of films with protein, which introduced changes in the refractive index through the films, thus promoting light scattering. The higher the protein ratio, the greater the light dispersion and the transparency reduction. Selective light absorption of LF led to film coloration, as commented on below. 
Table 2.3 Colour parameters of the films $\left(\mathrm{L}^{*}, \mathrm{Cab}^{*}, \mathrm{~h}^{*}\right)$, gloss at $60^{\circ}$ and $\mathrm{Ti}$ at $430 \mathrm{~nm}$ after 1 and 5 storage weeks at $25^{\circ} \mathrm{C}$ and $54 \% \mathrm{RH}$.

\begin{tabular}{|c|c|c|c|c|c|c|c|c|c|c|}
\hline \multirow{2}{*}{$\begin{array}{c}\text { Film } \\
\text { samples }\end{array}$} & \multicolumn{2}{|c|}{$\mathrm{L}^{*}$} & \multicolumn{2}{|c|}{$\mathrm{h}_{\mathrm{ab}} *$} & \multicolumn{2}{|c|}{$\mathrm{C}_{\mathrm{ab}} *$} & \multicolumn{2}{|c|}{$T_{i}(430 \mathrm{~nm})$} & \multicolumn{2}{|c|}{ Gloss $\left(60^{\circ}\right)$} \\
\hline & $1 w$ & $5 w$ & $1 \mathrm{w}$ & $5 w$ & $1 w$ & $5 w$ & $1 \mathrm{w}$ & $5 w$ & $1 \mathrm{w}$ & $5 w$ \\
\hline $0-0$ & $\begin{array}{c}84.6 \\
\pm 0.4^{e, 1}\end{array}$ & $\begin{array}{c}84.4 \\
\pm 0.7^{e, 1}\end{array}$ & $\begin{array}{c}286 \\
\pm 6^{b, 1}\end{array}$ & $\begin{array}{c}302 \\
\pm 3^{d, 2}\end{array}$ & $\begin{array}{c}1.2 \\
\pm 0.5^{a, 1}\end{array}$ & $\begin{array}{c}0.99 \\
\pm 0.13^{a, 1}\end{array}$ & $\begin{array}{c}0.858 \\
\pm 0.004^{\mathrm{e}, 1}\end{array}$ & $\begin{array}{c}0.850 \\
\pm 0.007^{c, 1}\end{array}$ & $\begin{array}{c}22.7 \\
\pm 1.9^{\mathrm{d}, 2}\end{array}$ & $\begin{array}{c}15 \\
\pm 3^{d, 1}\end{array}$ \\
\hline $0.1-0$ & $\begin{array}{c}77.35 \\
\pm 0.009^{a, 1}\end{array}$ & $\begin{array}{c}79.0 \\
\pm 0.2^{\mathrm{b}, 2}\end{array}$ & $\begin{array}{c}63.8 \\
\pm 0.5^{a, 1}\end{array}$ & $\begin{array}{c}63.41 \\
\pm 1.08^{\mathrm{b}, 1}\end{array}$ & $\begin{array}{c}8.3 \\
\pm 0.6^{d, 1}\end{array}$ & $\begin{array}{c}7.58 \\
\pm 0.05^{\mathrm{e}, 1}\end{array}$ & $\begin{array}{c}0.826 \\
\pm 0.002^{b, 1}\end{array}$ & $\begin{array}{c}0.832 \\
\pm 0.007^{\mathrm{b}, 1}\end{array}$ & $\begin{array}{c}8.3 \\
\pm 0.7^{a, 1}\end{array}$ & $\begin{array}{c}10.3 \\
\pm 0.9^{c, 2}\end{array}$ \\
\hline $0-0.1$ & $\begin{array}{c}83.1 \\
\pm 0.6^{d, 1}\end{array}$ & $\begin{array}{c}82.01 \\
\pm 1.15^{\mathrm{d}, 1}\end{array}$ & $\begin{array}{c}308 \\
\pm 17^{c, 1}\end{array}$ & $\begin{array}{c}308 \\
\pm 10^{d, 1}\end{array}$ & $\begin{array}{c}1.4 \\
\pm 0.5^{a, 1}\end{array}$ & $\begin{array}{c}1.2 \\
\pm 0.3^{a, 1}\end{array}$ & $\begin{array}{c}0.850 \\
\pm 0.005^{d, 1}\end{array}$ & $\begin{array}{c}0.851 \\
\pm 0.002^{c, 1}\end{array}$ & $\begin{array}{c}8.3 \\
\pm 0.7^{a, 1}\end{array}$ & $\begin{array}{c}8.8 \\
\pm 0.6^{\mathrm{ab}, 1}\end{array}$ \\
\hline $0.05-0.05$ & $\begin{array}{c}80.8 \\
\pm 0.9^{c, 2}\end{array}$ & $\begin{array}{c}79.0 \\
\pm 0.2^{\mathrm{b}, 1}\end{array}$ & $\begin{array}{c}67.13 \\
\pm 1.08^{a, 2}\end{array}$ & $\begin{array}{c}63.92 \\
\pm 1.12^{\mathrm{b}, 1}\end{array}$ & $\begin{array}{c}5.2 \\
\pm 0.8^{\mathrm{b}, 1}\end{array}$ & $\begin{array}{c}4.6 \\
\pm 0.2^{c, 1}\end{array}$ & $\begin{array}{c}0.840 \\
\pm 0.002^{c, 2}\end{array}$ & $\begin{array}{c}0.835 \\
\pm 0.005^{b, 1}\end{array}$ & $\begin{array}{c}8.5 \\
\pm 0.8^{a, 1}\end{array}$ & $\begin{array}{c}8.4 \\
\pm 0.8^{a, 1}\end{array}$ \\
\hline $0.2-0$ & $\begin{array}{c}76.4 \\
\pm 0.3^{a, 2}\end{array}$ & $\begin{array}{c}75.8 \\
\pm 0.5^{a, 1}\end{array}$ & $\begin{array}{c}59.0 \\
\pm 0.6^{\mathrm{a}, 2}\end{array}$ & $\begin{array}{c}57.36 \\
\pm 0.18^{a, 1}\end{array}$ & $\begin{array}{c}11.3 \\
\pm 1.2^{\mathrm{e}, 1}\end{array}$ & $\begin{array}{c}10.4 \\
\pm 0.3^{f, 1}\end{array}$ & $\begin{array}{c}0.811 \\
\pm 0.004^{a, 1}\end{array}$ & $\begin{array}{c}0.813 \\
\pm 0.006^{a, 1}\end{array}$ & $\begin{array}{c}8.23 \\
\pm 0.17^{a, 1}\end{array}$ & $\begin{array}{c}8.52 \\
\pm 0.16^{a b, 2}\end{array}$ \\
\hline $0-0.2$ & $\begin{array}{c}84.2 \\
\pm 0.9^{\mathrm{e}, 1}\end{array}$ & $\begin{array}{c}84.82 \\
\pm 1.13^{\mathrm{e}, 1}\end{array}$ & $\begin{array}{c}300 \\
\pm 13^{c, 1}\end{array}$ & $\begin{array}{l}292 \\
\pm 5^{c, 1}\end{array}$ & $\begin{array}{c}1.6 \\
\pm 0.7^{\mathrm{a}, 1}\end{array}$ & $\begin{array}{c}2.0 \\
\pm 0.5^{\mathrm{b}, 1}\end{array}$ & $\begin{array}{c}0.851 \\
\pm 0.003^{d, 1}\end{array}$ & $\begin{array}{c}0.853 \\
\pm 0.003^{c, 1}\end{array}$ & $\begin{array}{c}10.1 \\
\pm 0.6^{c, 2}\end{array}$ & $\begin{array}{c}9.6 \\
\pm 0.6^{\mathrm{bc}, 1}\end{array}$ \\
\hline $0.1-0.1$ & $\begin{array}{c}79.3 \\
\pm 1.3^{\mathrm{b}, 1}\end{array}$ & $\begin{array}{c}80.4 \\
\pm 1.5^{\mathrm{c}, 1}\end{array}$ & $\begin{array}{c}59.2 \\
\pm 1.3^{\mathrm{a}, 1}\end{array}$ & $\begin{array}{c}60.4 \\
\pm 1.4^{\mathrm{ab}, 1}\end{array}$ & $\begin{array}{c}6.8 \\
\pm 0.6^{c, 1}\end{array}$ & $\begin{array}{c}6.4 \\
\pm 0.8^{\mathrm{d}, 1}\end{array}$ & $\begin{array}{c}0.830 \\
\pm 0.004^{b, 1}\end{array}$ & $\begin{array}{c}0.837 \\
\pm 0.004^{b, 2}\end{array}$ & $\begin{array}{c}9.4 \\
\pm 0.7^{\mathrm{b}, 1}\end{array}$ & $\begin{array}{c}9.2 \\
\pm 0.5^{\mathrm{ab}, 1}\end{array}$ \\
\hline
\end{tabular}

Different letters $(a, b, c, d, e)$ in the same column indicate significant differences among the different formulations for the same storage time ( $p<0.05)$.

Different numbers $(1,2)$ in the same row indicate significant differences between both storage times for the same formulation $(P<0.05)$.

Sample codes refer to the mass ratio of LF (first digit) and LZ (second digit) with respect to PS. 
Net starch films were practically colourless, as revealed by the very low Chroma values and high lightness. Some lightness reduction was observed in the films after both 1 and 5 storage weeks, with no relevant effect of the protein ratio. LF incorporation had an important effect on the Chroma and hue values, causing a significant increase in both $(p<0.05)$, in agreement with its selective light absorption at low wavelength $(430 \mathrm{~nm})$. Coherently, those films with protein blend also showed Chroma increase and greater redness.

Gloss of the starch films was reduced by protein incorporation by about half, which can be attributed to the increase in their surface roughness associated with the protein migration to the film surface, observed by SEM. While no changes in gloss were observed for films containing proteins at different storage times, net starch films reduced their gloss during storage, such as has previously been observed by other authors (Jiménez et al. 2012; Cano et al. 2014). This change has been attributed to starch recrystallization on the film surface, with greater water availability and molecular mobility.

\subsection{Active properties}

\subsubsection{Antimicrobial properties}

Microbial counts obtained for protein solutions and films in the in vitro assays are shown in Table 2.4. As concerns the protein solutions, no notable reduction in the growth of L.innocua with respect to the control was observed at either $10^{\circ} \mathrm{C}$ or $25^{\circ} \mathrm{C}$, since only a small, but significant, reduction was detected at $25^{\circ} \mathrm{C}$ for LF with respect to the control sample. However, the mixture of both proteins resulted in a significant reduction in the growth of inoculated E.coli; at both tested temperatures. The application of both proteins resulted in a synergistic action against the Gram negative bacteria E.coli, which led to a decimal reduction of 1.3 and 1.9 at 10 and $25^{\circ} \mathrm{C}$, respectively. Barbiroli et al. (2012) observed similar behavior by applying both proteins against E.coli. The ability of the LF to increase the outer membrane's permeability can facilitate the access of $L Z$ to the peptidoglycan in the inner cell membrane. Nevertheless, no reduction in the growth of either bacterium was observed when LF and LZ were included in the PS films, probably due to the relatively weak activity detected in the proteins and the fact that their diffusion to the cells was hindered by the interactions with starch chains in the film matrix (section 3.2). In this sense, it is remarkable that counts in samples coated with protein-free starch films were significantly higher than in the uncoated control sample, which reveals that the 
starch support can act as an effective nutrient for bacteria, while inhibiting the protein diffusion to the culture medium.

Table 4. Microbial counts of L.innocua and E.coli after a period of incubation of $24 \mathrm{~h}$ at $10^{\circ} \mathrm{C}$ and $25^{\circ} \mathrm{C}$ on TSA-NaCl medium for pure protein solutions and films. Mean values and standard deviations of $\log \mathrm{CFU} / \mathrm{cm}^{2}$.

\begin{tabular}{|c|c|c|c|c|c|}
\hline \multirow{2}{*}{\multicolumn{2}{|c|}{ Formulation }} & \multicolumn{2}{|c|}{ L.innocua } & \multicolumn{2}{|c|}{ E.coli } \\
\hline & & $10^{\circ} \mathrm{C}$ & $25^{\circ} \mathrm{C}$ & $10^{\circ} \mathrm{C}$ & $25^{\circ} \mathrm{C}$ \\
\hline \multirow{4}{*}{$\begin{array}{l}\text { Protein } \\
\text { solution }\end{array}$} & Control & $2.6 \pm 0.3^{a b}$ & $6.9 \pm 0.3^{b}$ & $3.57 \pm 0.09^{b}$ & $7.73 \pm 0.19^{d}$ \\
\hline & LF & $2.4 \pm 0.2^{\mathrm{ab}}$ & $6.41 \pm 0.08^{a}$ & $3.41 \pm 0.04^{b}$ & $7.1 \pm 0.2^{b}$ \\
\hline & $L Z$ & $2.25 \pm 0.04^{a}$ & $6.8 \pm 0.3^{b}$ & $3.52 \pm 0.09^{b}$ & $7.41 \pm 0.14^{c}$ \\
\hline & LF-LZ & $2.60 \pm 0.09^{b}$ & $6.86 \pm 0.14^{b}$ & $2.3 \pm 0.2^{a}$ & $5.86 \pm 0.02^{a}$ \\
\hline \multirow{5}{*}{ Films } & Control & $2.5 \pm 0.2^{a}$ & $6.91 \pm 0.14^{a}$ & $2.15 \pm 0.05^{a}$ & $7.18 \pm 0.17^{b c}$ \\
\hline & $0-0$ & $2.8 \pm 0.3^{b}$ & $7.32 \pm 0.10^{\mathrm{cd}}$ & $2.90 \pm 0.06^{\mathrm{e}}$ & $6.88 \pm 0.10^{a}$ \\
\hline & $0.2-0$ & $2.90 \pm 0.09^{b}$ & $7.07 \pm 0.11^{b}$ & $2.33 \pm 0.05^{b}$ & $6.83 \pm 0.07^{\mathrm{a}}$ \\
\hline & $0-0.2$ & $2.87 \pm 0.08^{b}$ & $7.34 \pm 0.07^{d}$ & $2.51 \pm 0.05^{b}$ & $7.31 \pm 0.05^{c}$ \\
\hline & $0.1-0.1$ & $2.86 \pm 0.07^{b}$ & $7.17 \pm 0.07^{b c}$ & $2.43 \pm 0.03^{c}$ & $7.04 \pm 0.04^{b}$ \\
\hline
\end{tabular}

Different letters $(a, b, c, d)$ in the same column indicate significant differences among the different formulations for the same bacterium and incubation conditions $(p<0.05)$.

Accordingly, when films with and without proteins were applied to minced meat (Figure 2.7), no notable antimicrobial activity was observed, since no significant differences $(p<0.05)$ in the counts of total aerobic meat bacteria of the different samples were found after 15 incubation days. Both proteins and their mixtures embedded in the films were ineffective against the natural aerobic microbiota of minced meat pork. However, in samples coated with films containing both proteins (0.1-0.1), the coliform counts after 14 incubation days showed a reduction of about $1 \mathrm{log}$, with respect to the samples coated with the control film (without proteins). As observed in the in vitro test, samples coated with the control film exhibited higher coliform counts than uncoated samples. The results agree with what was observed in in vitro assay, with respect to the nutritive role of the starch support for bacteria and the synergistic action against Gram negative bacteria of combined proteins. Neither LF nor LZ were effective enough when they were applied separately, but a weakly enhanced antimicrobial activity against E.coli and coliform microbiota of pork meat was observed when they were combined. 

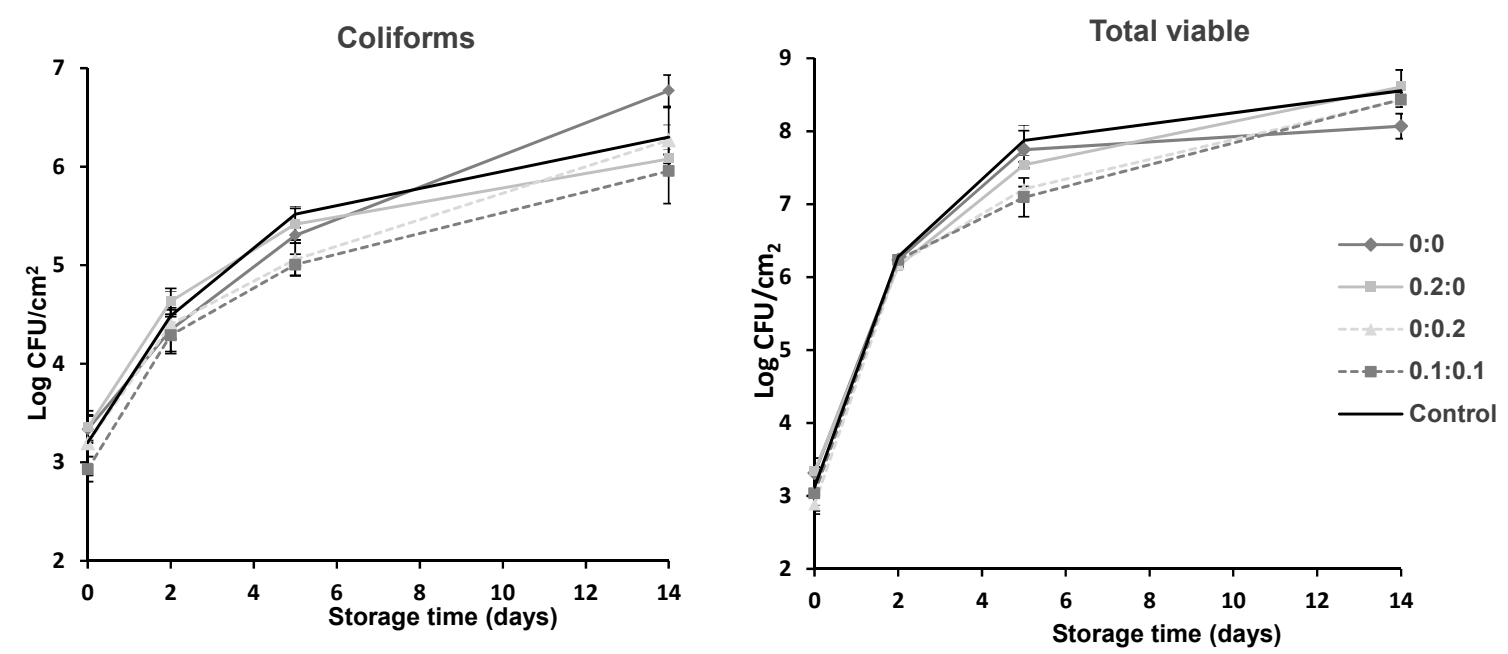

Figure 2.7 Microbial counts of minced pork meat samples coated with PS based edible films containing $L F$ and/or $L Z$ as a function of storage time at $10{ }^{\circ} \mathrm{C}$. Mean values and standard deviation. Control $=$ non-coated samples.

\subsubsection{Antioxidant properties}

The antioxidant capacity of proteins, expressed as TEAC value (trolox equivalent antioxidant capacity) in g protein/L was $13.2 \pm 0.7,15.3 \pm 0.4$ and $15.4 \pm 0.6$, respectively for LF, LZ and their blend. So, the antioxidant activity of LF was significantly higher than those obtained for LZ and the LF-LZ blend $(p<0.05)$. LF has previously been pointed out as a protein with antioxidant ability, mainly due to its strong chelation capacity of transition metals. Therefore, its use as a natural antioxidant preservative in food has great potential (Stejins and Hooijdonk, 2000). LZ showed lower antioxidant ability than LF $(p<0.05)$, but it was high enough for LZ to be considered as a natural antioxidant compound. No synergistic activity between either protein was observed for the LF-LZ mixture.

Figure 2.8 shows peroxide values of lard samples, both uncoated and coated with the films, after differing storage times. Low PV values, with no significant differences among the samples, were obtained after relatively short storage periods. Nevertheless, they increased considerably after long storage times. In this case, significant differences were observed for both uncoated and coated samples. This can be attributed to the low oxygen permeability of the films (Table 2.2), which inhibits the oxygen reactions with the substrate. Among the samples coated with the different films, the highest. 


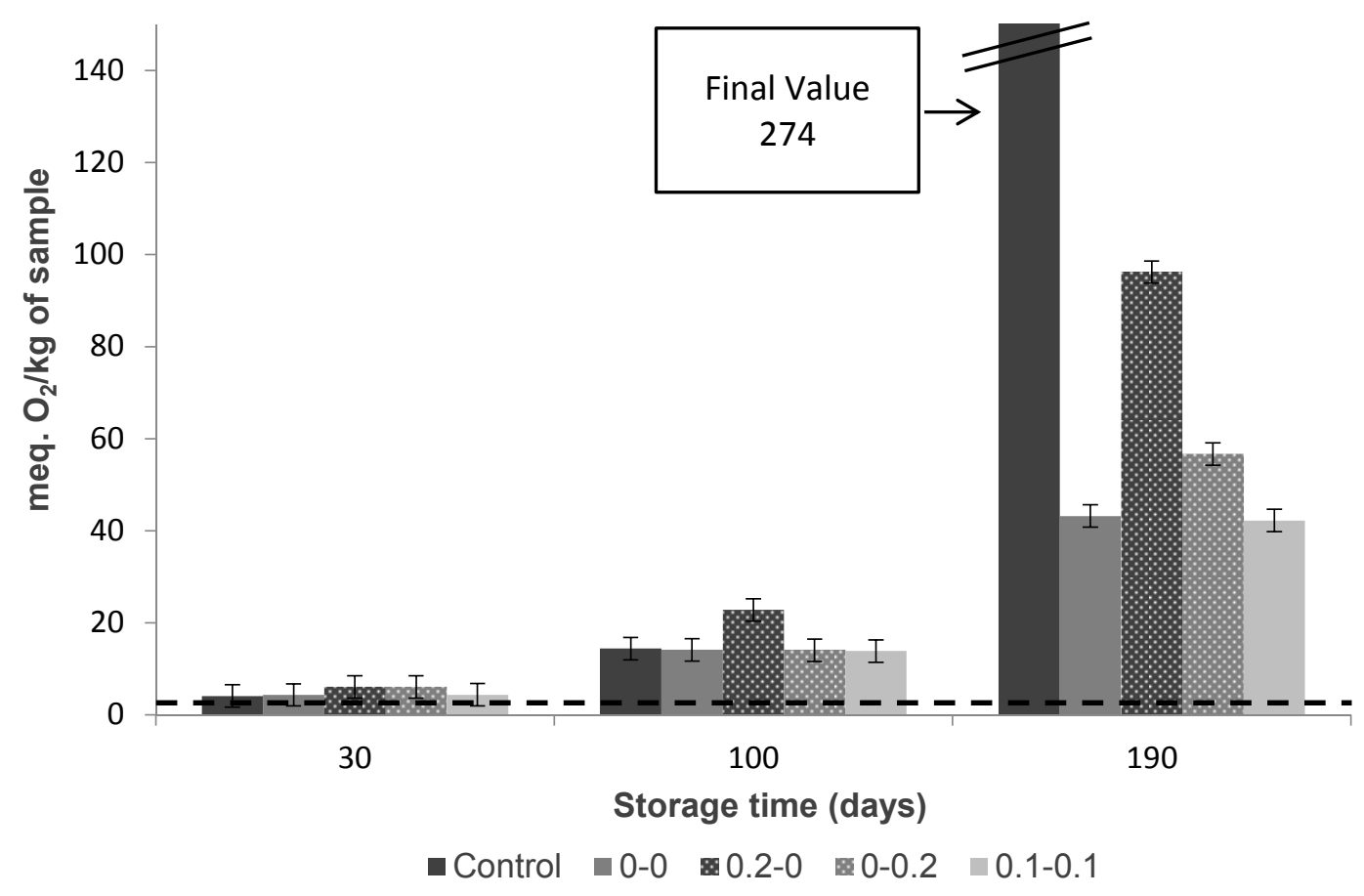

Figure 2.8 Peroxide value (PV) of fat samples coated with PS based edible films containing $\mathrm{LF}$ and/or $\mathrm{LZ}$ at different storage times at $40^{\circ} \mathrm{C}$ and $53 \% \mathrm{RH}$. Mean values and $95 \%$ LSD intervals. Control = non-coated samples. Dashed line corresponds to the $\mathrm{PV}$ initial value of the fat.

OP value was obtained for the films containing $0.2 \mathrm{~g} \mathrm{LF} / \mathrm{g}$ starch, despite the fact that the highest antioxidant activity was found for LF in the TROLOX test. This could be due to the inherent iron content of LF which could promote oxidation reactions at high concentrations of the protein, as reported by Nielsen et al., (2004). 


\section{CONCLUSIONS}

he incorporation of antimicrobial proteins (lactoferrin and/or lysozyme) had an impact on the structural and physical properties of potato starch films and affected their thermal behaviour by increasing the glass transition temperature. Both proteins showed a certain degree of compatibility with starch chains through the bond formations which increased the Tg values, while a part separates and migrates to the film surface, there giving rise to globular heterogeneous formations. The incorporation of proteins, especially lactoferrin, greatly increased the film's brittleness, regardless of the film's water content, although they enhanced the water vapour and oxygen barrier properties. The protein also reduced the film's transparency and gloss, while lactoferrin induced colour changes, associated with its selective light absorption. The thermal degradation of blend films and isolated proteins occurred at temperatures of over $250^{\circ} \mathrm{C}$, which means that starch-protein blends can be thermoprocessed according to the starch's thermoplastic properties and following the usual practices of the plastics industries. The films containing a blend of lactoferrin and lysozyme reduced the total coliform counts in minced pork meat, but did not show significant antimicrobial activity against $L$. innocua and $E$. coli. Nevertheless, all the films were effective at reducing lard oxidation after long storage times. Studies into the release kinetics of the bioactive proteins or peptides in food systems are required to establish the usefulness of both LF and LZ in developing biodegradable and bioactive packaging materials.

\section{Acknowledgements}

The authors acknowledge the financial support provided by the Generalitat Valenciana (GV/2013/152) and Ministerio de Economía y Competividad (Projects AGL2013-42989-

$\mathrm{R})$ and the services rendered by the Electron Microscopy Service of the UPV. Olga Moreno Marro also thanks the Ministerio de Educación, Cultura y Deporte for the FPU 2012-1121 grant. 


\section{REFERENCES}

Arnold, R. R., \& Cole, M. F. (1977). A bactericidal effect for human lactoferrin. Science, 197(4300), 263-265.

Atarés, L., Bonilla, J., \& Chiralt, A. (2010). Characterization of sodium caseinate-based edible films incorporated with cinnamon or ginger essential oils. Journal of Food Engineering, 100(4), 678-687.

ASTM. (1995). Standard test methods for water vapour transmission of materials. In Standard designations: E96-95 annual book of ASTM standards. Philadelphia, PA: American Society for Testing and Materials.

ASTM. (1999). Standard test methods for specular gloss. Designation (D523): Annualbook of ASTM standards (Vol. 06.01) Philadelphia, PA: American Society for Testing and Materials.

ASTM. (2001). Standard test method for tensile properties of thin plastic sheeting. In Standard D882 annual book of American Standard Testing Methods. Philadelphia,PA: American Society for Testing and Materials. ASTM.

ASTM. (2005). Standard test method for oxygen gas transmission rate through plasticfilm and sheeting using a coulometric sensor. In Standard designation: D398505:annual book of American Society for Testing Materials. West Conshohocken, PA: ASTM.

Azeredo, H. M. C. d. (2009). Nanocomposites for food packaging applications. Food Research International, 42(9), 1240-1253.

Barbiroli, A., Bonomi, F., Capretti, G., lametti, S., Manzoni, M., Piergiovanni, L., et al. (2012). Antimicrobial activity of lysozyme and lactoferrin incorporated in cellulose-based food packaging. Food Control,26 (2), 387-392.

Barnett, I., (2012). Packaging Solutions Throughout the Supply Chain: Technology, Trends and Future Outlook. Business Insight, London.

Branen, J. K., \& Davidson, P. M. (2004). Enhancement of nisin, lysozyme, and monolaurin antimicrobial activities by ethylendiaminetetraacetic acid and lactoferrin. International Journal of Food Microbiology, 90, 63-74.

Buonocore, G.G., Conte, A., Corbo, M.R., Sinigaglia, M., Del Nobile, M.A., (2005). Monoand multilayer active films containing lysozyme as antimicrobial agent. Innovative Food Science and Emerging Technologies 6, 459-464. 
Byun, Y., \& Kim, Y. T. (2014). Chapter 14 - bioplastics for food packaging: Chemistry and physics. In J. H. Han (Ed.), Innovations in food packaging (second edition) (pp. 353368). San Diego: Academic Press.

Cano, A., Jiménez, A., Cháfer, M., Gónzalez, C., \& Chiralt, A. (2014). Effect of amylose:Amylopectin ratio and rice bran addition on starch films properties. Carbohydrate Polymers, 111(0), 543-555.

Corradini, C., Alfieri, I., Cavazza, A., Lantano, C., Lorenzi, A., Zucchetto, N., et al. (2013). Antimicrobial films containing lysozyme for active packaging obtained by sol-gel technique. Journal of Food Engineering, 119(3), 580-587.

Corrales, M., Fernández, A., \& Han, J. H. (2014). Chapter 7 - antimicrobial packaging systems. In J. H. Han (Ed.), Innovations in food packaging (second edition) (pp. 133170). San Diego: Academic Press

Das, D.K., Dutta, H., Mahanta, C.L., 2013. Development of a rice starch-based coating with antioxidant and microbe-barrier properties and study of its effect on tomatoes stored at room temperature. LWT_Food Science Technology. 50, 272-278.

Drago, M.E. (2006). Actividades antibacterianas de lactoferrina. Enfermedades Infecciosas y Microbiología, 26 (2), 58-63.

Elias, R. J., Kellerby, S. S., \& Decker, E. A. (2008). Antioxidant activity of proteins and peptides. Critical Reviews in Food Science and Nutrition, 48(5), 430-441.

Ellison, R. D., Giehl, T. J., \& LaForce, F. M. (1988). Damage of the outer membrane of enteric gram-negative bacteria by lactoferrin and transferrin. Infection and Immunity, 56(11), 2774-2781.

Farahnaky, A., Farhat, I. A., Mitchell, J. R., \& Hill, S. E. (2009). The effect of sodium chloride on the glass transition of potato and cassava starches at low moisture contents. Food Hydrocolloids, 23(6), 1483-1487.

Farnaud, S., \& Evans, R. W. (2003). Lactoferrin-a multifunctional protein with antimicrobial properties. Molecular Immunology, 40(7), 395-405.

García-Montoya, I. A., Cendón, T. S., Arévalo-Gallegos, S., \& Rascón-Cruz, Q. (2012). Lactoferrin a multiple bioactive protein: An overview. Biochimica Et Biophysica Acta (BBA) - General Subjects, 1820(3), 226-236.

Gemili, S., Yemenicioglu, A., Altınkaya, S.A., (2009). Development of cellulose acetate based antimicrobial food packaging materials for controlled release of lysozyme. Journal of Food Engineering 90, 453-462.

Gill, A. O., \& Holley, R. A. (2000). Inhibition of bacterial growth on ham and bologna by lysozyme, nisin and EDTA. Food Research International, 33, 83-90. 
Gimenez, B., Gomez-Guillen, M.C., Perez-Mateos, M., Montero, P., Marquez-Ruiz, G., 2011. Evaluation of lipid oxidation in horse mackerel patties covered with boragecontaining film during frozen storage. Food Chemistry. 124, 1393-1403.

González-Chávez, S. A., Arévalo-Gallegos, S., \& Rascón-Cruz, Q. (2009). Lactoferrin: structure, function and applications. International journal of antimicrobial agents, 33(4), 301-e1.

Güçbilmez, Ç. M., Yemenicioğlu, A., \& Arslanoğlu, A. (2007). Antimicrobial and antioxidant activity of edible zein films incorporated with lysozyme, albumin proteins and disodium EDTA. Food Research International, 40(1), 80-91.

Gyawali, R., \& Ibrahim, S. A. (2014). Natural products as antimicrobial agents. Food Control, 46(0), 412-429.

Han, J. H., Seo, G. H., Park, I. M., Kim, G. N., \& Lee, D. S. (2006). Physical and mechanical properties of pea starch edible films containing beeswax emulsions. Journal of Food Science, 71(6), E290-E296.

Han, J.H., Hwang, H.-M., Min, S., Krochta, J.M., 2008. Coating of peanuts with edible whey protein film containing a-tocopherol and ascorbyl palmitate. Journal of Food Science. 73, 1750-3841.

He, Y., Kong, W., Wang, W., Liu, T., Liu, Y., Gong, Q., et al. (2012). Modified natural halloysite/potato starch composite films. Carbohydrate Polymers, 87(4), 2706-2711.

Huang, D., Ou, B., \& Prior, R. L. (2005). The chemistry behind antioxidant capacity assays. Journal of Agricultural and Food Chemistry, 53(6), 1841-1856.

Hutchings, J. B. (1999). Food and colour appearance (2nd ed.). Gaithersburg, MD:Chapman and Hall Food Science Book, Aspen Publication.

Jenssen, H., \& Hancock, R. E. W. (2009). Antimicrobial properties of lactoferrin. Biochimie, 91(1), 19-29.

Jiménez, A., Fabra, M. J., Talens, P., \& Chiralt, A. (2012). Effect of re-crystallization on tensile, optical and water vapour barrier properties of corn starch films containing fatty acids. Food Hydrocolloids, 26(1), 302-310.

Jiménez, A., Fabra, M. J., Talens, P., \& Chiralt, A. (2013). Phase transitions in starch based films containing fatty acids. effect on water sorption and mechanical behaviour. Food Hydrocolloids, 30(1), 408-418.

Joubran, Y., Mackie, A., \& Lesmes, U. (2013). Impact of the Maillard reaction on the antioxidant capacity of bovine lactoferrin. Food chemistry, 141(4), 3796-3802.

Kaur, B., Ariffin, F., Bhat, R., \& Karim, A. A. (2012). Progress in starch modification in the last decade. Food Hydrocolloids, 26(2), 398-404. 
Kechichian, V., Ditchfield, C., Veiga-Santos, P., \& Tadini, C. C. (2010). Natural antimicrobial ingredients incorporated in biodegradable films based on cassava starch. LWT - Food Science and Technology, 43(7), 1088-1094.

Kristo, E., Koutsoumanis, K. P., \& Biliaderis, C. G. (2008). Thermal, mechanical and water vapor barrier properties of sodium caseinate films containing antimicrobials and their inhibitory action on Listeria monocytogenes. Food Hydrocolloids, 22(3), 373-386.

Lee, D. S. (2014). Chapter 6 - antioxidative packaging system. In J. H. Han (Ed.), Innovations in food packaging (second edition) (pp. 111-131). San Diego: Academic Press.

Lin, L., Wang, B., Wang, M., Cao, J., Zhang, J., Wu, Y., et al., 2008. Effects of a chitosan-based coating with ascorbic acid on post-harvest quality and core browning of 'Yali' pears (Pyrus bertschneideri Rehd.). Journal of the Science of Food and Agriculture. 88, 877-884.

Liu, H., Zheng, F., Cao, Q., Ren, B., Zhu, L., Striker, G., \& Vlassara, H. (2006). Amelioration of oxidant stress by the defensin lysozyme. American Journal of Physiology-Endocrinology and Metabolism, 290(5), 824-832.

Ma, X., Chang, P. R., \& Yu, J. (2008). Properties of biodegradable thermoplastic pea starch/carboxymethyl cellulose and pea starch/microcrystalline cellulose composites. Carbohydrate Polymers, 72(3), 369-375.

Mc Hugh, T. H., Avena-Bustillos, R., \& Krochta, J. M. (1993). Hydrophobic edible films: modified procedure for water vapor permeability and explanation of thickness effects. Journal of Food Science, 58(4), 899-903.

Monedero, F. M., Fabra, M. J., Talens, P., \& Chiralt, A. (2010). Effect of calcium and sodium caseinates on physical characteristics of soy protein isolate-lipid films. Journal of Food Engineering, 97(2), 228-234.

Moreira, M. R., Ponce, A. G., Del Valle, C. E., \& Roura, S. I. (2005). Inhibitory parameters of essential oils to reduce a foodborne pathogen. LWT - Food Science and Technology, 38, 565-570.

Moreno, O., Pastor, C., Muller, J., Atarés, L., González, C., Chiralt., A. (2014). Physical and bioactive properties of corn starch - Buttermilk edible films. Journal of Food Engineering 141, 27-36.

Nielsen, N. S., Petersen, A., Meyer, A. S., Timm-Heinrich, M., \& Jacobsen, C. (2004). Effects of lactoferrin, phytic acid and EDTA on oxidation in two food emulsions enriched with long-chain polyunsaturated fatty acids. Journal of Agricultural and Food Chemistry, 52(25), 7690-7699.

Pan, Y., Shiell, B., Wan, J., Coventry, M. J., Roginski, H., Lee, A., et al. (2007). The molecular characterisation and antimicrobial activity of amidated bovine lactoferrin. International Dairy Journal, 17(6), 606-616. 
Pastor, C., Sánchez-González, L., Cháfer, M., Chiralt, A., \& González-Martínez, C. (2010). Physical and antifungal properties of hydroxypropylmethylcellulose based films containing propolis as affected by moisture content. Carbohydrate Polymers, 82(4), 1174-1183.

Pyla, R., Kim, T., Silva, J. L., \& Jung, Y. (2010). Enhanced antimicrobial activity of starch-based film impregnated with thermally processed tannic acid, a strong antioxidant. International Journal of Food Microbiology, 137(2-3), 154-160.

Re, R., Pellegrini, N., Proteggente, A., Pannala, A., Yang, M., \& Rice-Evans, C. (1999). Antioxidant activity applying an improved ABTS radical cation decolorization assay. Free radical biology and medicine, 26(9), 1231-1237.

Realini, C. E., \& Marcos, B. (2014). Active and intelligent packaging systems for a modern society. Meat Science, 98(3), 404-419.

Reyes, R. E., Manjarrez, H. A., \& Drago, M. E. (2005). El hierro y la virulencia bacteriana. Enfermedades Infecciosas y Microbiología, 25, 104-7.

Samarasinghe, R. M., Kanwar, R. K., \& Kanwar, J. R. (2014). The effect of oral administration of iron saturated-bovine lactoferrin encapsulated chitosan-nanocarriers on osteoarthritis. Biomaterials, 35(26), 7522-7534.

Sánchez-García, M.D., Giménez, E., \& Lagaron, J.M. (2008). Morphology and barrier properties of solvent cast composites of thermoplastic biopolymers and purified cellulose fibers. Carbohydrate Polymers 71, 235-244.

Sánchez-González, L., Cháfer, M., Hernández, M., Chiralt, A., \& González-Martínez, C. (2011). Antimicrobial activity of polysaccharide films containing essential oils. Food Control, 22(8), 1302-1310.

Soares, R. M. D., Lima, A. M. F., Oliveira, R. V. B., Pires, A. T. N., \& Soldi, V. (2005). Thermal degradation of biodegradable edible films based on xanthan and starches from different sources. Polymer Degradation and Stability, 90(3), 449-454.

Steijns, J. M., \& Van Hooijdonk, A. C. M. (2000). Occurrence, structure, biochemical properties and technological characteristics of lactoferrin. British Journal of Nutrition, 84(S1), 11-17.

Sung, S. Y., Sin, L. T., Tee, T. T., Bee, S. T., Rahmat, A. R., Rahman, W. A. W. A., ... \& Vikhraman, M. (2013). Antimicrobial agents for food packaging applications. Trends in Food Science \& Technology, 33(2), 110-123.

Suzuki, T., Yamauchi, K., Kawase, K., Tomita, M., Kiyosawa, I., \& Okonogi, S. (1989). Collaborative bacteriostatic activity of bovine lactoferrin with lysozyme against Escherichia coli 0111. Agricultural and biological chemistry, 53(6), 1705-1706.

Wakabayashi, H., Yamauchi, K., \& Takase, M. (2006). Lactoferrin research, technology and applications. International Dairy Journal, 16(11), 1241-1251. 
Wilhelm, H. -., Sierakowski, M. -., Souza, G. P., \& Wypych, F. (2003). Starch films reinforced with mineral clay. Carbohydrate Polymers, 52(2), 101-110.

Yamauchi, K. (1992). Biologically functional proteins of milk and peptides derived from milk proteins. Bulletin of the International Dairy Federation, 272, 51-58.

Zhang, Y., Rempel, C., \& McLaren, D. (2014). Chapter 16 - thermoplastic starch. In J. H. Han (Ed.), Innovations in food packaging (second edition) (pp. 391-412). San Diego: Academic Press. 


\section{INFLUENCE OF THE PROCESSING METHOD AND ANTIMICROBIAL AGENTS ON PROPERTIES OF STARCH- GELATIN BIODEGRADABLE FILMS}

Olga Moreno*, Raúl Díaz, Lorena Atarés, Amparo Chiralt.

Departamento de Tecnología de Alimentos - Instituto de Ingeniería de Alimentos para el Desarrollo. Universitat Politècnica de València, Camino de Vera s/n 46022 Valencia, Spain

Polymer International, 65(8), 905-914 


\section{ABSTRACT}

iodegradable films based on corn starch (CS), bovine gelatin (BG), glycerol (GL) as a plasticizer, and lysozyme (LZ) or N-a-lauroyl-l-arginine ethyl ester monohydrochloride (LAE) as antimicrobial agents were obtained by both, extension-drying (casting) of the aqueous dispersions and melt blending and compression molding. Microstructural analyses revealed the lack of miscibility between CS and BG, which implied polymer phase separation, with the formation of domains rich in each polymer, with different arrangement for casting and melt-blending processes. Thermo-processed films were more permeable to water vapor (60-115\%) and oxygen (70-355 \%), compared to the corresponding casting films and exhibited lower stiffness (50-75 \%) and resistance to break (17-33\%) and greater extensibility (150-190\%) than casting films. LAE improved water vapor barrier and reduced oxygen barrier of the both kinds of films, whereas the opposite effect was observed for LZ. Antimicrobial activity against Listeria innocua was observed for formulations containing LAE processed by both casting and compression molding, all of which exhibited a bactericidal effect.

KEYWORDS: corn starch, bovine gelatin, lysozyme, LAE, Listeria innocua. 


\section{INTRODUCTION}

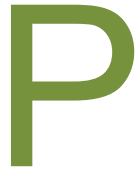

etroleum-derived synthetic plastics have been traditionally used as packaging materials due to their availability, low cost, good mechanical and barrier properties and their thermo-processing ability. In the food industry, these materials are broadly used as packaging materials to preserve and protect food from physical damage, oxidation and microbial spoilage. However, the accumulation of these non-biodegradable materials is a serious environmental problem while their recycling incurs a high cost. This is why new materials based on biodegradable polymers have been developed in the last few years (Tharanathan, 2003).

Starch and gelatin are biodegradable materials, widely available, low cost and with very good film forming ability (Barnett, 2011; Moreno et al., 2014; Ortega-Toro et al., 2014; Wilhelm et al., 2003). The combination of TPS (thermoplastic starch) with other polymers, such as gelatin, has been pointed out as a way of enhancing film mechanical behavior, leading to films with higher resistance and elongation capacity (Acosta et al., 2015; Al-Hassan and Norziah, 2012; Fakhoury et al., 2012, 2013). Previous works reflected that the starch:gelatin combination (1:1 mass ratio) yielded films with improved mechanical resistance and extensibility (Acosta et al., 2015).

Incorporation of bioactive agents into biodegradable films enhanced their functionality and added value to obtain active packaging materials. These compounds also favour the preservation of the packaging itself. Developing active films is a very useful strategy in order to prevent the growth of spoilage microorganisms, hence prolonging the shelf-life of the food products and maintaining their quality. Some of the most widely studied natural bioactive agents are essential oils, phenolic compounds, bacteriocines and enzymes (Bayarri et al., 2014; Corradini et al., 2013).

Lysozyme (LZ) is among the antimicrobial enzymes that have been incorporated into biodegradable polymer materials to obtain active packaging (Muriel-Galet et al., 2014). It is broadly stable, and as it has a high isoelectric point ( $p / \approx 11)$, it is positively charged at the $\mathrm{pH}$ of most food products (Bayarri et al., 2014). The antimicrobial activity of this protein is based on its ability to break the bonds between $\mathrm{N}$-acetylmuramic acid and $\mathrm{N}$ acetylglucosamine of the peptidoglycan of the cell walls of Gram positive bacteria (Güçbilmez et al., 2007). Egg White lysozyme is considered as GRAS (generally 
recognized as safe) by the Food and Drug Administration (FDA), and used as a food additive E-1105.

Ethyl lauril arginate ( $\mathrm{N}$ - $\alpha$-lauroyl-l-arginine ethyl ester monohydrochloride, LAE), is a cationic surfactant derived from lauric acid, L-arginine, and ethanol. It is considered as one of the most potent food antimicrobial agents with a wide spectrum of antimicrobial activity (Muriel-Galet et al., 2014). It interacts with the cell membranes and causes the membrane protein denaturation, which increases its permeability and causes cell growth inhibition or even death (Rodríguezet al., 2004).

LAE can be metabolized to yield digestible compounds, which is why it is considered GRAS by FDA, and it has been accepted as food additive E243 (Hawkins et al., 2009; Higueras et al., 2013). It has recently been incorporated into food packaging materials, such as polyethylene terephthalate and polypropylene, and even biodegradable matrices, such as etilen-vinil-alcohol (Muriel-Galet et al., 2015) and chitosan (Higueras et al., 2013). LAE is predominantly hydrophilic and hence tends to be located in the aqueous phase of food, where the antimicrobial activity takes place. It is chemically stable within the range $\mathrm{pH} 3$ to 7 , which includes most food products. It is effective even at lower concentrations than other food preservatives, which makes it a promising additive for biodegradable films (Higueras et al., 2013).

The novelty of this study resides in the possibility of enhancing the functionality and added value of starch-gelatin films by means of the incorporation of lysozyme or LAE in order to obtain active packaging materials for food applications, based on their low cost and food compatibility. In this sense, both, the casting method, which are useful for food coating, and thermoplastic processing, with potential industrial scale-up, have been studied. Thus, the aim of the present work was to obtain active films based on starchgelatine blends, by incorporating LZ or LAE, using both casting and thermoprocessing methods. The effect of active compounds and processing method on the microstructure, functional properties and antimicrobial power against Listeria innocua of the blend films was analysed. Total migration values of the different films into distinct food simulants were also determined. 


\section{MATERIALS AND METHODS}

\subsection{Materials}

The following materials were used for film preparation: Corn starch (CS) (Roquette Laisa España, S.A., Valencia, Spain); Bovine gelatin type A (BG) (Sancho de Borja, S.L., Zaragoza, Spain); liofilized lysozyme (LZ) (Fluka Analytical, Sigma-Aldrich Chemie $\mathrm{GmbH}$, Steinheim, Germany); Ethyl lauroyl arginate (LAE) at $10 \% \mathrm{w} / \mathrm{v}$ in ethanol (Vedeqsa, Lamirsa, Terrassa, Spain). All other chemicals were reagent grade supplied by Panreac Química S.A. (Castellar del Vallés, Barcelona, Spain). Tryptic Soy Broth (TSB), Palcam Agar Base, Agar Bacteriological and Buffered Peptone Water were from (Scharlab, Barcelona, Spain). Listeria innocua (CECT 910) was provided by the Colección Española de Cultivos Tipo (CECT, Burjassot, Valencia, Spain). Micrococcus lysodeikticus ATCC 4698 was purchased from Sigma, Steinheim, Germany.

\subsection{Lysozyme activity}

The enzyme activity of lysozyme was determined by a spectrophotometric method as described by previous authors (Shugar, 1952), using a spectrophotometer (Helios Zeta UV-VIS, Thermo Fisher Scientific, UK). The absorbance reduction, caused by the lysis of Micrococcus lysodeikticus $(0.015 \% \mathrm{w} / \mathrm{v})$, for $5 \mathrm{~min}$, was measured at $450 \mathrm{~nm}$ and $25{ }^{\circ} \mathrm{C}$ (Shugar, 1952).

The cells were suspended at $0.01 \%(\mathrm{w} / \mathrm{v})$ in phosphate buffer $(66.6 \mathrm{mM}, \mathrm{pH} 6.24)$, aiming to achieve an initial absorbance of between 0.6 and 0.7 at $450 \mathrm{~nm}$ and $25^{\circ} \mathrm{C}$. A lysozyme solution (200-400 units $/ \mathrm{mL}$ ) was prepared using the same buffer, and $100 \mu \mathrm{l}$ of this solution were mixed with $2.5 \mathrm{~mL}$ of $M$. lysodeikticus suspension. The absorbance was monitored at $25^{\circ} \mathrm{C}$ for 5 minutes. A mixture of $2.5 \mathrm{~mL}$ of Micrococcus suspension and $100 \mu \mathrm{L}$ of buffer was used as blank.

The initial slope of the absorbance vs. time curve was used to quantify the enzymatic activity. This was expressed as units of lysozyme per $\mathrm{mg}(\mathrm{U} / \mathrm{mg})$. One unit corresponds to a change in absorbance of 0.001 in $1 \mathrm{~min}$ (Fabra et al., 2014). Each analysis was carried out in triplicate. 


\subsection{Film preparation}

Three different film forming formulations were prepared using corn starch and bovine gelatin (wt. ratio 1:1) as blend matrix, using glycerol as plasticizer. Control films (CF) and films with lysozyme (LZ) or LAE were considered. Both bioactive compounds were added at a polymer:compound wt.ratio of 1:0.1. Two different techniques were used in order to obtain each film formulation, namely casting ( $\mathrm{C}$ films) and melt blending plus thermocompression ( $P$ films). The amount of plasticizer was fitted in each process to obtain handling films by using the minimum amount as possible to reduce its negative effects. In the case of casting films, glycerol was added at $25 \%$ wt. with respect to the total polymer mass, whereas this ratio was $30 \%$ wt. for thermo-processed films. Therefore, six film types were obtained: control films (CCF and PCF), films with LZ (CLZ and PLZ), and films with LAE (CLAE and PLAE), by using casting or thermocompression, respectively.

To obtain casting films, CS was dispersed in distilled water (2\% wt.) and stirred for 5 minutes. In order to induce starch gelatinization, it was immersed in a thermostatic bath at $100{ }^{\circ} \mathrm{C}$ for $30 \mathrm{~min}$, and then cooled down to room temperature. BG dispersion (2\% wt) was prepared at $40{ }^{\circ} \mathrm{C}$ under magnetic stirring for $30 \mathrm{~min}$. Additionally, LZ dispersion at $10 \%$ wt. was prepared under stirring at $800 \mathrm{rpm}$ for $20 \mathrm{~min}$ at $25^{\circ} \mathrm{C}$. CS and BG dispersions were mixed in the adequate proportions to obtain the control films (CCF). Glycerol (25 g/100 g polymer) and LZ or LAE (10\% w/v in ethanol) solutions were added to obtain CLZ and CLAE films with $10 \mathrm{~g}$ of active $/ 100 \mathrm{~g}$ polymer. The mass of film forming dispersion corresponding to $1.5 \mathrm{~g}$ solids was poured in Teflon plates $(150 \mathrm{~mm}$ diameter) and dried for $48 \mathrm{~h}$ at $45 \% \mathrm{RH}$ and $25^{\circ} \mathrm{C}$. Dried films were separated from the plates and conditioned for one week at $25{ }^{\circ} \mathrm{C}$ and $53 \% \mathrm{RH}$ (in desiccators with saturated solutions of magnesium nitrate) prior to analyses.

Compression molded films were obtained by mixing the dry components, CS, BG (and LZ when present) in the proportions defined. The dry blend was mixed with glycerol and water using polymers:glycerol:water mass ratios of 1:0.3:1.1. For films containing LAE, the corresponding amount of the LAE ethanol solution was added to the polymerglycerol-water blend.

Each mixture was hot-blended in a two-roll mill (Model LRM-M-100, Labtech Engineering, Thailand) at $160^{\circ} \mathrm{C}$ and $8 \mathrm{rpm}$ for 10 minutes until a homogeneous blend was obtained. The pellets obtained were conditioned for one week at $25^{\circ} \mathrm{C}$ and $53 \% \mathrm{RH}$ using saturated solutions of magnesium nitrate. The films were obtained by compression 
molding using a hot-plate press (Model LP20, Labtech Engineering, Thailand). Four grams of the blend were preheated at $160^{\circ} \mathrm{C}$ for $5 \mathrm{~min}$ in the press plate and then pressed at $160{ }^{\circ} \mathrm{C}$ and 30 bar for $2 \mathrm{~min}$, followed by 130 bar for $6 \mathrm{~min}$. Thereafter, a cooling cycle to $6{ }^{\circ} \mathrm{C}$ for 3 min was applied. The films were finally conditioned in the same way as those obtained by casting.

\subsection{Microstructural and physical film characterization}

\subsubsection{Film microstructure}

Cross section and surface images of the films were obtained by Field Emission Scanning Electron Microscopy (FESEM), with a microscope ZEISS $尺$, model ULTRA 55 (Germany). Prior to analysis, the samples were conditioned in desiccators containing $\mathrm{P}_{2} \mathrm{O}_{5}$ for $48 \mathrm{~h}$. For the cross-section observations, samples were cryofractured by immersion in liquid nitrogen. All the samples were mounted on cupper stubs and coated with platinum.

\subsubsection{Tensile properties}

The tensile behavior was analyzed following the standard method (ASTM D882, 2001) using a texture analyzer (TA-XTplus, Stable Micro Systems, Surrey, United Kingdom). Twelve replicates per film sample, using film strips (25 mm wide, $100 \mathrm{~mm}$ long), were considered. Prior to every test, the film thickness was measured at four different points by using a hand-held digital micrometer (Electronic Digital Micrometer, Comecta S.A., Barcelona, Spain). Equilibrated film specimens were mounted in the film extension grips and stretched at $50 \mathrm{~mm} \mathrm{~min}^{-1}$ until breaking. Elastic modulus (EM), tensile strength (TS) and elongation at break ( $\% \mathrm{E}$ ) were determined from stress-strain curves, estimated from force-deformation data.

\subsubsection{Optical properties: translucency, color and gloss}

The reflectance spectra of the films (400 to $700 \mathrm{~nm})$ were obtained with a spectrocolorimeter MINOLTA, model CM-3600d (Minolta CO, Tokyo, Japan), on both a black $\left(R_{0}\right)$ and a white $(R)$ background of known reflectance. The internal transmittance of the films $\left(T_{i}\right)$ was calculated from these spectra, as an indicator of the film transparency, using the Kubelka-Munk theory (Hutching, 1999) for multiple scattering. 
The reflectance for an infinite film thickness, $R_{\infty}$, was also determined to obtain color CIE$L^{*} a^{*} b^{*}$ parameters (CIE, 1986), using illuminant $D_{65}$ and observer $10^{\circ}$. Color coordinates, Lightness $\left(\mathrm{L}^{*}\right)$ chrome $\left(\mathrm{C}_{\mathrm{ab}}{ }^{*}\right)$ and hue $\left(\mathrm{h}_{\mathrm{ab}}{ }^{*}\right)$, as well as the whiteness index (WI) of the samples, were calculated according previous works (Atarés et al., 2010). Six samples per formulation were measured.

The gloss of the films was measured according to the standard method (ASTM D523, 1999 ) at $60^{\circ}$ incidence angle, using a flat surface gloss meter (Multi.Gloss 268, Minolta, Germany). Six samples per formulation and three measurements per sample were taken. For casting films, measurements were taken on the side which was in contact with air during drying. Results were expressed as gloss units, relative to a highly polished surface of black glass standard with a value near to 100 .

\subsubsection{Moisture content and barrier properties}

The moisture content of film samples previously conditioned at $53 \% \mathrm{RH}$ was determined in six samples per formulation. Samples were dried in a vacuum oven $\left(60^{\circ} \mathrm{C}-24 \mathrm{~h}\right)$ and, subsequently, conditioned in desiccators with $\mathrm{P}_{2} \mathrm{O}_{5}$ until constant weight was reached. The results were expressed as $\mathrm{g}$ of water per $\mathrm{g}$ of dry film.

The water vapour permeability (WVP) of the films was determined following a modification of the gravimetric method (ASTM E96-95, 1995), as described by other authors (McHugh et al., 1993). Six samples (35 mm diameter) per formulation were analyzed. Film thickness was measured with a hand-held digital micrometer (Electronic Digital Micrometer, Comecta S.A., Barcelona, Spain) at six points. The film samples were secured in Payne permeability cups (Elcometer SPRL, Hermelle/s Argenteau, Belgium) containing $5 \mathrm{~mL}$ of distilled water (100\% RH). Then, the cups were placed in a pre-conditioned cabinet at $25{ }^{\circ} \mathrm{C}$ and $53 \% \mathrm{RH}$ using magnesium nitrate saturated solutions. In order to reduce the resistance to transport of water vapour, a fan was placed above each cup. The cups were weighed periodically $( \pm 0.00001$, ME36S Sartorius, Germany) every $1.5 \mathrm{~h}$, until steady state had been reached (24 h).

The oxygen permeability (OP) of the films was determined by using an OX-TRAN (Model 2/21 ML Mocon Lippke,Neuwied, Germany) following the standard method (ASTM D3985-05, 2005). Measurements were carried out at $53 \% \mathrm{RH}$ and $25{ }^{\circ} \mathrm{C}$ on samples with $50 \mathrm{~cm}^{2}$ of exposed area. The sample thickness was measured at six points before the test using a hand-held digital micrometer (Electronic Digital Micrometer, Comecta 
S.A., Barcelona, Spain). Two replicates per formulation were made. The OP was calculated from the oxygen transmission rate, taking into account the film thickness.

\subsubsection{Film solubility and swelling in water}

Water solubility and swelling of the films were determined by using a modification of the method described by Balaguer et al., (2011). Film samples of $3 \times 3 \mathrm{~cm}^{2}$ were initially conditioned for 2 weeks in a desiccator over $\mathrm{P}_{2} \mathrm{O}_{5}$ (zero theoretical equilibrium moisture content) to obtain dried films. Weighed $\left(W_{d}^{i}\right)$ dried film samples were immersed in $10 \mathrm{~mL}$ of distilled water, gently stirred and kept in contact for $24 \mathrm{~h}$ at $25^{\circ} \mathrm{C}$. Then, the samples were taken out from the solvent, gently drained and weighed $\left(\mathrm{W}_{\mathrm{w}}{ }^{f}\right)$. The total water content of the wet films was determined by conditioning them in desiccators over $\mathrm{P}_{2} \mathrm{O}_{5}$ till constant weight $\left(\mathrm{W}_{d}^{f}\right)$. Three replicates per formulation were run. The solubility of the films was expressed as the weight loss (WL \%) of the samples (Equation 3.1) in $\mathrm{g} / 100 \mathrm{~g}$ of dried film, while the swelling capacity was estimated as the water uptake $(\Delta \mathrm{W})$ (Equation 2) and expressed as $\mathrm{g}$ water/100 $\mathrm{g}$ of final dried film.

$$
\begin{aligned}
& W L \%=\frac{W_{d}^{i}-W_{d}^{f}}{W_{d}^{i}} \cdot 100 \\
& \Delta W \%=\frac{W_{w}^{f}-W_{d}^{f}}{W_{d}^{f}} \cdot 100
\end{aligned}
$$

(Equation 2)

\subsubsection{Overall Migration}

Overall migration tests of the films conditioned for 1 week at $53 \% \mathrm{RH}$ were carried out following the current legislation (Comission Regulation (EU) 10/2011). Film samples with a total area of $20.8 \mathrm{~cm}^{2}$ were immersed in $50 \mathrm{~mL}$ of different food simulants: distilled water, simulant $A$ (ethanol $10 \% \mathrm{v} / \mathrm{v}$, simulating hydrophilic foods), simulant $\mathrm{B}$ (acetic acid $3 \% \mathrm{w} / \mathrm{v}$, simulating low $\mathrm{pH}$ hydrophilic foods) and simulant D2 (isooctane, simulating lipophilic foods with free fats at the surface). All the samples were kept in contact with the simulants for 10 days at $20^{\circ} \mathrm{C}$, to simulate any food contact under frozen and refrigerated conditions. After incubation, the film samples were removed from the simulants, which were evaporated to dryness. The final mass of the residues determines the overall migration value. The results were expressed as $\mathrm{mg}$ of total constituents released per $\mathrm{dm}^{2}$ of film. All the tests were run in duplicate. 


\subsubsection{Thermogravimetric analysis}

The thermal stability of the films was analyzed using a thermogravimetric analyzer (TGA/SDTA 851e, Mettler Toledo, Schwerzenbach, Switzerland). Approximately $3 \mathrm{mg}$ of preconditioned sample were used in each test. The sample was heated from room temperature to $600^{\circ} \mathrm{C}$, under nitrogen flow $(50 \mathrm{~mL} / \mathrm{min})$, at $10^{\circ} \mathrm{C} / \mathrm{min}$. Two replicates per formulation were run.

\subsection{Antimicrobial characterization}

The antimicrobial activity of the films with $L Z$ and LAE was analyzed using the Gram positive bacterium Listeria innocua (CECT 910). The strain used, initially frozen in TSB with $30 \%$ glycerol, was regenerated by inoculation in $10 \mathrm{ml}$ TSB. After incubation $(24 \mathrm{~h}$ at $37^{\circ} \mathrm{C}$ ), $10 \mu \mathrm{l}$ were transferred into $10 \mathrm{ml} \mathrm{TSB}$, which was incubated for $24 \mathrm{~h}$ at the same temperature to obtain the work culture.

Agar plates with $10 \mathrm{~mL}$ of TSA-NaCl (3\%) were inoculated with $10^{2} \mathrm{CFU} / \mathrm{cm}^{2}$ of L.innocua (diluted from the work culture), and completely covered by a film with the same surface as the plate. An inoculated plate without film was used as inoculum control, and films without antimicrobial agents (CCF and PCF) were used as control films. All the plates were incubated at $37^{\circ} \mathrm{C}$ for $24 \mathrm{~h}$, and bacterium counts were performed at different times of incubation (0,5 and $24 \mathrm{~h}$ ), using a specific medium for Listeria, Palcam agar. All the tests were run in duplicate.

\subsection{Statistical analysis}

The statistical analysis of the data was performed through analysis of variance (ANOVA) using Statgraphics Centurion XVI s for Windows 5.1 (Manugistics Corp., Rockville, Md.) 


\section{RESULTS AND DISCUSSION}

\subsection{Microstructural and physical film characterization}

\subsubsection{Microstructure of the films}

Figure 3.1 and Figure 3.2 show the images of the cross sections and surface of the films, obtained by FESEM. Figure 3.1 illustrates the differing internal microstructure of the control films (starch and gelatin blends) obtained by casting and compression molding. The former (CCF) shows a stratified arrangement of the polymers, caused by their limited miscibility, which forms during the drying step. Phase separation occurs during this step and the gelatin-rich phase (with low density) is predominant at the top of the film, whereas the starch-rich phase (with higher density) remains mainly distributed at the bottom of the film. This polymer arrangement is also evidenced at surface level (Figure 3.2), where the gelatin domains can be observed as globular formations, as previously seen in casting films of similar composition by other authors (Acosta et al., 2015). Polymer phase separation could also be observed in control films obtained by compression molding (PCF), even though no gravitational stratification can take place in this case. Figure 3.1 shows the lack of complete adhesion of both phases at the interface of different polymer domains. The PCF surface (Figure 3.2) shows a fibrous structure which could be attributed to the gelatin chain aggregations. This polymer tends to acquire a tridimensional structure similar to collagen, through the aggregation of its helical conformation (Acosta et al., 2015).

The incorporation of LZ into the films seems to enhance the interactions between the two polymers, hence favouring the blending, both for casting and compression-molding films. Figure 3.1 shows some degree of polymer phase separation in CLZ and PLZ films, but the interfacial adhesion appears to be improved as compared to the control films. The surface of casting films with lysozyme (Figure 3.2) also exhibits globular forms, but to a lesser extent than the control films. PLZ samples show less clearly delineated fibrous structures than PCF control films, thus indicating a better degree of gelatin and starch phase blending. 

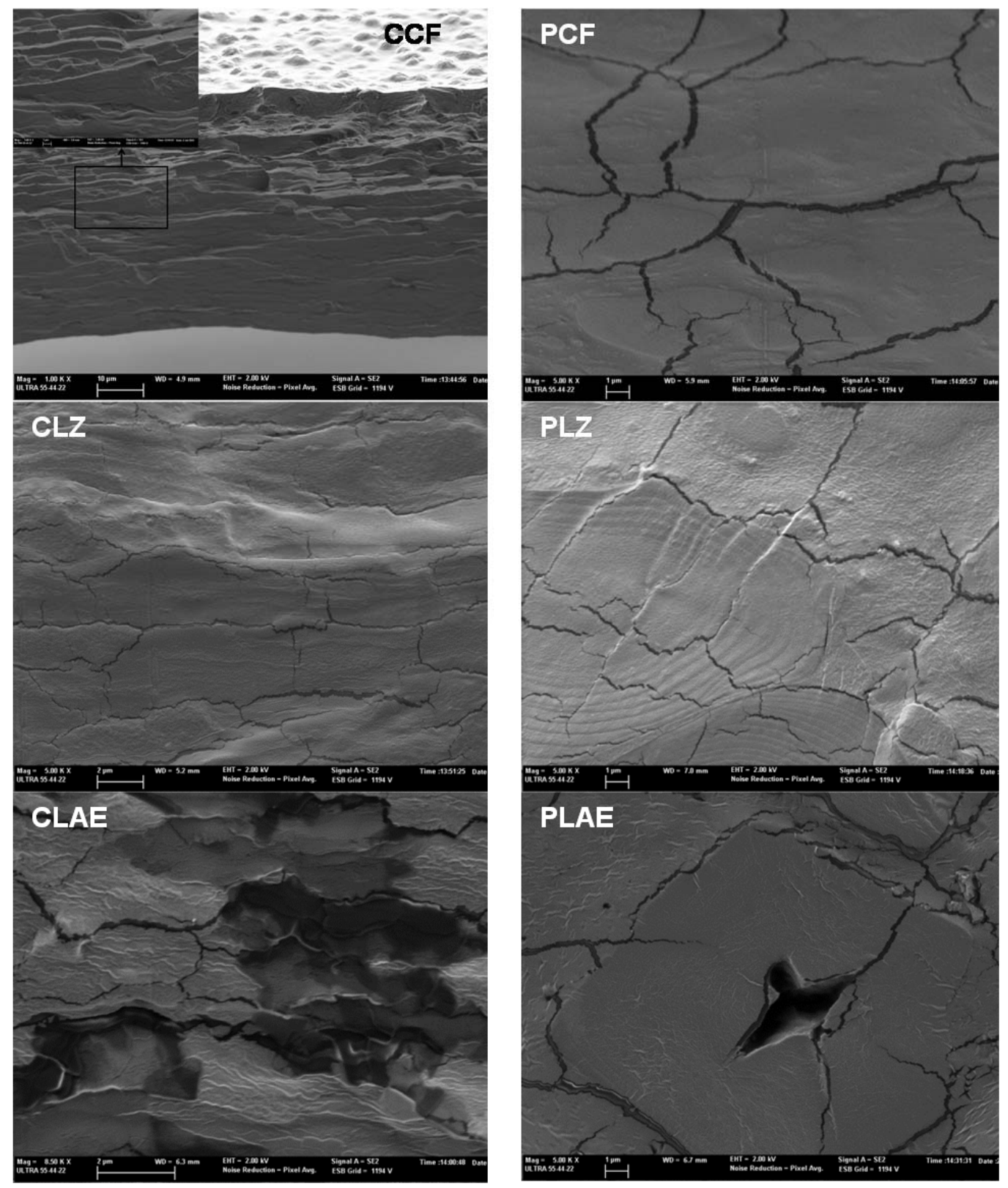

Figure 3.1 FESEM images of the cross section of control films and films containing LZ and LAE, obtained by casting (left) and compression molding (right). Bar in CCF corresponds to $10 \mu \mathrm{m}$ and for the included micrograph, at higher magnification, to $2 \mu \mathrm{m}$; bars in CLZ and CLAE correspond to $2 \mu \mathrm{m}$ and, in PCF, PLZ and PLAE, to $1 \mu \mathrm{m}$. 

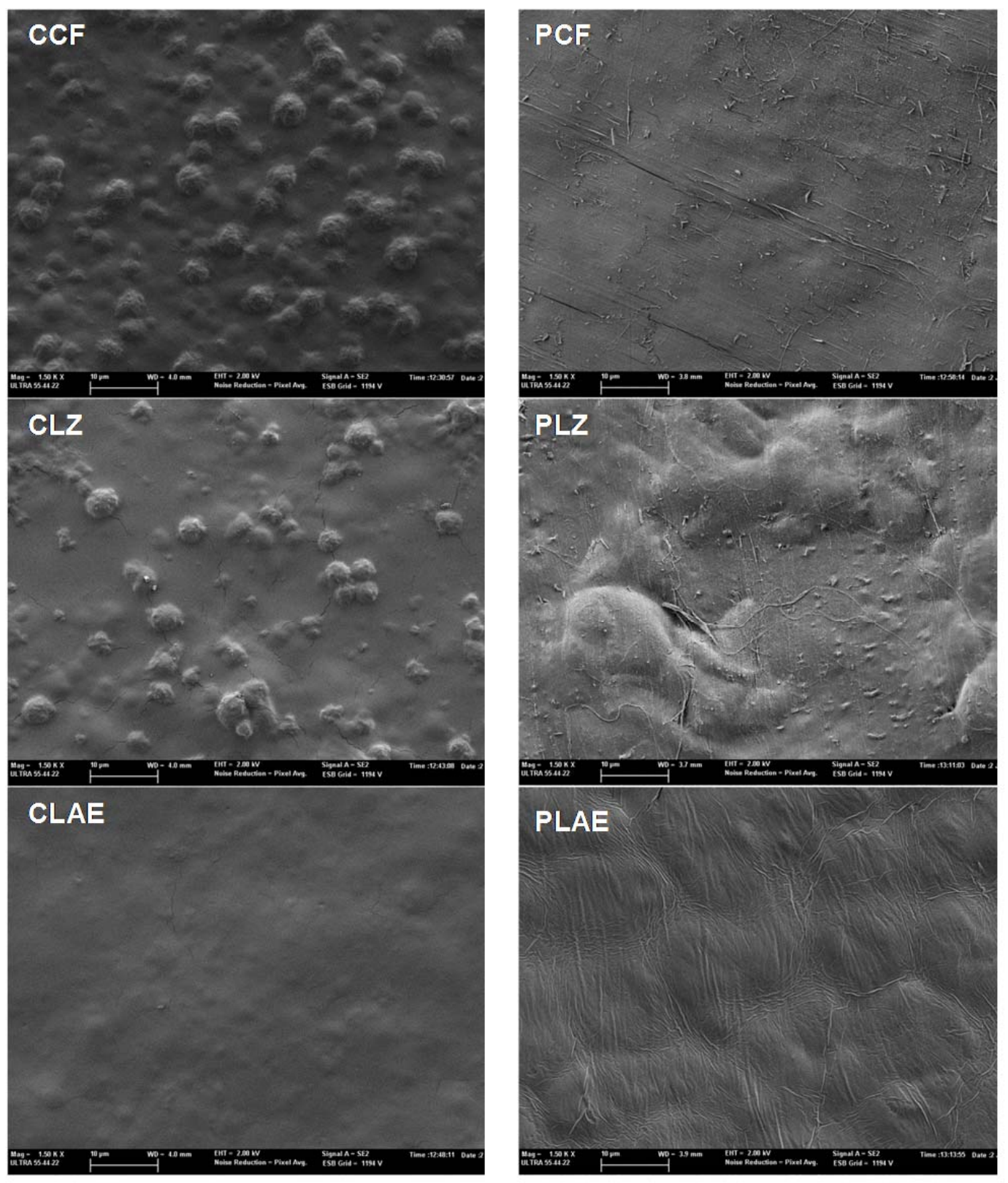

Figure 3.2 FESEM images of the surface of control films and films containing $L Z$ and LAE, obtained by casting (left) and compression molding (right). Bars in all micrographs correspond to $10 \mu \mathrm{m}$.

In films with LAE, the starch and gelatin domains were smaller, which suggests the improvement of the polymer blending capacity caused by this surfactant compound. The internal structure of PLAE films showed some gaps, probably caused by air incorporation during the homogenization step, favoured by the surfactant effect of LAE. The surface of films with LAE was more homogeneous, coherently with the better polymer homogenization due to the interfacial action of this compound. 
So, the amphiphilic nature of $L Z$, and especially of $L A E$, contributed to enhance blending capacity of starch and gelatin phases, thus giving rise to a different microstructural arrangement in the polymer matrix. Likewise, casting or compression molding processes seriously affected film microstructure due to the differences in the polymer chain interactions which occurred in the aqueous solution during film drying or in the melt blending process, as well as the gravitationally induced stratification of separate polymer phases during the drying step of casting films.

\subsubsection{Tensile properties}

Table 3.1 shows the film thickness values, along with the tensile parameters: elastic modulus (EM), tensile strength at break (TS) and percentage elongation at break (\% E) of the films. The compression molding method led to a significantlly increased film thickness, as compared to the casting method, due to the low flowability of the material in the compression step.

Table 3.1 Values of thickness (mm) and tensile parameters (EM (MPa), TS (MPa) and \% E) of the films equilibrated at $53 \%$ of $\mathrm{RH}$ at $25^{\circ} \mathrm{C}$. Average values and standard deviation.

\begin{tabular}{lcccc}
\hline Formulation & Thickness $(\mathrm{mm})^{\mathrm{EM}}(\mathrm{MPa})$ & TS $(\mathrm{MPa})$ & $\% \mathrm{E}$ \\
\hline CCF & $0.065 \pm 0.006^{\mathrm{a}}$ & $1021 \pm 194^{\mathrm{d}}$ & $33 \pm 6^{\mathrm{e}}$ & $14 \pm 5^{\mathrm{a}}$ \\
\hline CLZ & $0.065 \pm 0.004^{\mathrm{a}}$ & $461 \pm 15^{\mathrm{c}}$ & $18 \pm 2^{\mathrm{C}}$ & $32 \pm 9^{\mathrm{b}}$ \\
\hline CLAE & $0.061 \pm 0.003^{\mathrm{a}}$ & $512 \pm 95^{\mathrm{c}}$ & $24 \pm 7^{\mathrm{d}}$ & $35 \pm 2^{\mathrm{b}}$ \\
PCF & $0.180 \pm 0.014^{\mathrm{b}}$ & $110 \pm 42^{\mathrm{b}}$ & $15 \pm 2^{\mathrm{b}}$ & $94 \pm 19^{\mathrm{c}}$ \\
\hline PLZ & $0.227 \pm 0.012^{\mathrm{c}}$ & $119 \pm 34^{\mathrm{b}}$ & $16.4 \pm 0.2^{\mathrm{bc}}$ & $100 \pm 28^{\mathrm{c}}$ \\
\hline PLAE & $0.176 \pm 0.013^{\mathrm{b}}$ & $21.6 \pm 1.8^{\mathrm{a}}$ & $3.4 \pm 0.3^{\mathrm{a}}$ & $29 \pm 3^{\mathrm{b}}$ \\
\hline
\end{tabular}

Different letters $(a, b, c, d, e)$ in the same column indicate significant differences among the different formulations $(p<0.05)$.

The tensile parameters of the casting control films (CCF) were in the order of those reported by previous works (Acosta et al., 2015) for films of similar composition. In general, thermo-pressed films were less rigid, less resistant to fracture and more stretchable than casting films, which can be explained by their different microstructure. In the casting films, both polymer phases are partially separated in the film forming solution, but the polymer chains can extend and interact to a different extent throughout the drying 
step, thus giving rise to two independent networks with strong chain attraction within each homopolymer phase and weaker interactions at the polymer interfaces. On the other hand, in the films obtained by compression molding, polymer domains of different sizes were produced during the melt blending step, which offers less opportunity for the development of molecular interactions. A great contact surface between the two polymer phases is produced, with weak adhesion forces at the interface. Differences in the film thickness for casting and thermo-processed films will also affect their tensile properties.

Lysozyme addition affected the tensile behavior of the compression molded films. As compared to the corresponding control film (PCF), lysozyme addition did not significantly affect the tensile properties of the thermoprocessed films, although the interfacial action of LZ in thermo-compressed films resulted in an improved polymer adhesion (Figure 1). However, casting films with lysozyme (CLZ) were significantly less rigid and resistant, but more stretchable than the corresponding control film (CCF).

On the other hand, LAE addition affected the tensile behavior of the films obtained by both methods. In comparison with control films, films with LAE became less rigid and resistant $(p<0.05)$ in both casting and thermo- compression methods. This reduction of the strength parameters is justified by the improved dispersion of starch and gelatin phases (smaller domains) caused by LAE addition, thus exhibiting greater interfacial area where adhesion forces are weaker. The film extensibility was increased in casting films (CLAE), and notably reduced for those obtained by compression molding (PLAE). The increased extensibility of casting films could be related to the sliding of the polymer chains during the tensile test favoured by the interfacial action of LAE, whereas in the control film (CCF) the intermingled phases show more resistance and lower deformability. On the contrary, the interfacial action of LAE seems to be less effective in the thermo-compression process, since polymer phases are structured as adhered smaller domains (greater interfacial area) with some gaps, which makes the film rupture easier, as compared to the corresponding control film (PCF).

On the other hand, the degree of crystallinity in both polymer phases could also have a remarkable effect on the tensile response of the films obtained by the different methods. In the casting films, aggregation and crystallization phenomena are liable to occur during the drying step due to the high molecular mobility of the polymer chains, whereas this molecular arrangement is much less probable in thermo-compressed films, which will exhibit more amorphous and less resistant structures (Jiménez et al., 2012). 


\subsubsection{Optical properties}

The values of the optical parameters of the films (lightness, chrome, hue, whiteness index and gloss at $60^{\circ}$ ) are reported in Table 3.2. The film processing method significantly affected the colour of the films. Compression molding yielded darker films with higher chrome and lower hue than those obtained by casting $(p<0.05)$. The films obtained by compression molding had some reddish coloration, indicating that some browning reactions take place during the thermal process. On the contrary, the casting films were almost white (with low chrome, regardless of the hue value).

Table 3.2 Values of the colour parameters ( $L^{*}$, Lightness; $C_{a b}{ }^{*}$, Chrome; $h_{a b}{ }^{*}$, hue), Whiteness Index (WI) and Gloss at $60^{\circ}$ for the different film formulations. Average values and standard deviation.

\begin{tabular}{|c|c|c|c|c|c|}
\hline Formulation & $\mathbf{L}^{\prime}$ & $\mathrm{C}_{\mathrm{ab}}$ & $\overline{h_{a b}}$ & WI & Gloss $\left(60^{\circ}\right)$ \\
\hline CCF & $80.6 \pm 0.5^{d}$ & $7.3 \pm 0.2^{b}$ & $98.0 \pm 0.3^{d}$ & $79.4 \pm 0.4^{\mathrm{e}}$ & $12.1 \pm 0.7^{\mathrm{a}}$ \\
\hline CLZ & $81.4 \pm 0.3^{\mathrm{e}}$ & $7.4 \pm 0.4^{b}$ & $98.6 \pm 0.8^{d}$ & $80.0 \pm 0.3^{\mathrm{e}}$ & $14.1 \pm 0.9^{b}$ \\
\hline CLAE & $73.8 \pm 0.6^{c}$ & $4.36 \pm 0.13^{a}$ & $104.0 \pm 0.9^{\mathrm{e}}$ & $73.4 \pm 0.6^{d}$ & $18.7 \pm 1.3^{C}$ \\
\hline PCF & $62.32 \pm 1.05^{b}$ & $30.4 \pm 1.3^{d}$ & $83.6 \pm 0.7^{b}$ & $51.6 \pm 0.9^{b}$ & $12 \pm 4^{\mathrm{a}}$ \\
\hline PLZ & $54.7 \pm 0.2^{a}$ & $33 \pm 3^{\mathrm{e}}$ & $76.5 \pm 2^{a}$ & $43.9 \pm 1.9^{a}$ & $19 \pm 4^{C}$ \\
\hline PLAE & $62.3 \pm 0.7^{b}$ & $26.1 \pm 1.8^{C}$ & $85.5 \pm 0.4^{c}$ & $54.3 \pm 0.2^{c}$ & $19 \pm 4^{c}$ \\
\hline
\end{tabular}

Different letters $(a, b, c, d, e)$ in the same column indicate significant differences among the different formulations $(p<0.05)$.

Lysozyme addition did not affect the colour of casting films, whereas in compression molded films, this compound led to a lightness and hue reduction, and a chrome increase $(p<0.05)$, giving rise to more brownish films, as compared to PCF. LAE incorporation in casting films resulted in a significant decrease in lightness and chrome, whereas hue increased $(p<0.05)$. However, when this compound was incorporated into compression molded films, chrome was significantly reduced $(p<0.05)$ while WI increased with respect to the corresponding control films, thus indicating that less film browning was produced in this case. In fact, of the compression molded films, PLAE were the least affected by browning. The whiteness index values were coherent with the colour parameters, and they were significantly higher in casting films $(p<0.05)$. These results suggest that melt blending and compression molding could not represent a convenient strategy to obtain starch-gelatin films since the dark brown discoloration 
evidences some degradation of the materials occurring during the thermal process, although $L A E$ incorporation mitigated these effects.

For both processing methods, LZ and LAE addition resulted in a significant gloss increase $(p<0.05)$ and no significant effect of the method was observed. The gloss increase can be attributed to the surface roughness reduction (fewer globular formations), as deduced from the FESEM observations in Figure 2.

Figure 3.3 shows the internal transmittance $\left(T_{i}\right)$ spectra of the films, as an indicator of their transparency. The processing method was the factor that mainly affected this property; the films obtained by casting were more transparent (higher $T_{i}$ values) than those obtained by compression molding. The addition of LZ and LAE only affected the transparency of the compression molded films. With respect to the control film (PCF), PLZ showed the lowest $T_{i}$ values, hence being the least transparent films, whereas LAE addition led to a transparency increase in compression molded films (PLAE).

The reduction of $T_{i}$ at low wavelength may be attributable to the browning products absorbing light between 400 and $500 \mathrm{~nm}$. These compounds may result from Maillard reactions (condensation reactions between protein amine groups and carbohydrate carbonyl groups) or the caramelization of the carbohydrates, both enabled by the high process temperature. In this sense, it is remarkable that LZ and LAE provoked different effects, both having amino groups but probably with different reactivity.

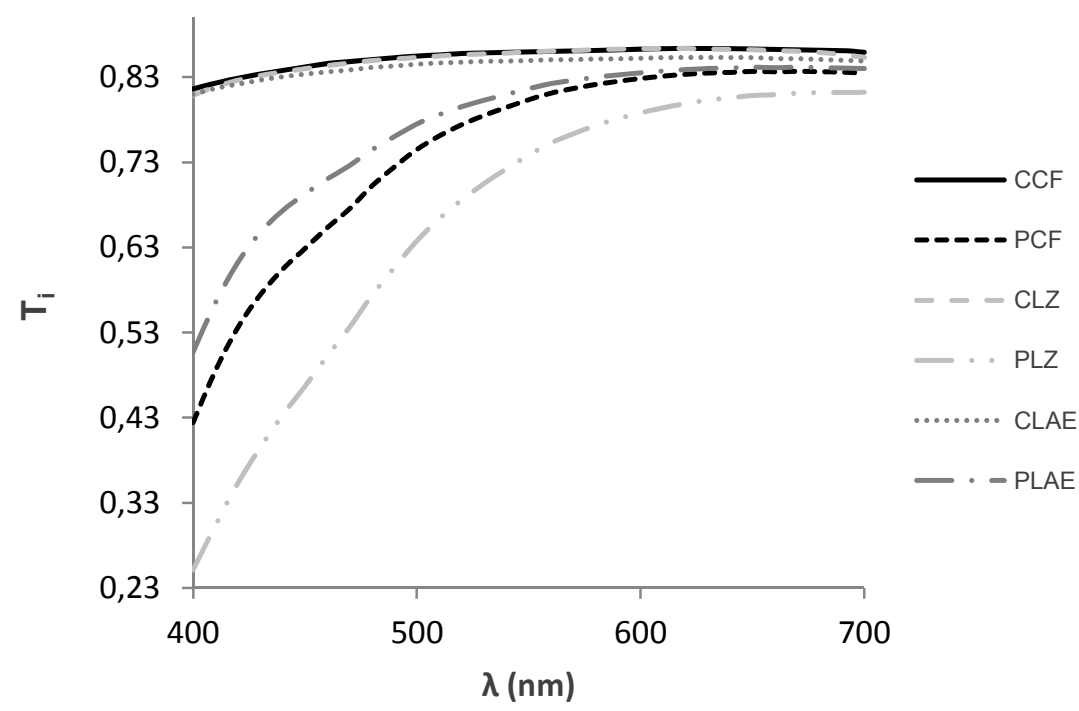


Figure 3.3 Spectral distribution of internal transmittance between 400 and $700 \mathrm{~nm}$, for the different film formulations obtained by casting $(C)$ and compression molding $(P)$.

\subsubsection{Moisture content and barrier properties}

Table 3.3 shows the equilibrium moisture content of the films $\left(X_{w}, g\right.$ water per $g$ dry film), their water vapor permeability (WVP) and their oxygen permeability (OP). The moisture content was slightly lower in thermoprocessed films and casting films with LAE, whereas LZ casting films showed the highest value, although the differences are not very remarkable and could be attributed to the different structural arrangement of polymers which could imply a different ratio of active points for water adsorption. The reduction of water affinity provoked by the LAE addition in the films, suggests that a slightly more hydrophobic matrix is produced in this case, whereas the opposite trend was observed for LZ films. Nevertheless, these effects disappeared in thermoprocessed films, where browning reactions, occurred during heating, may involve polar groups, thus contributing to the overall reduction of the number of active sites for water adsorption.

Table 3.3 Values of the barrier properties (WVP, Water Vapour Permeability; OP, Oxygen Permeability) and equilibrium moisture content (Xw). Average values and standard deviation.

\begin{tabular}{lccc}
\hline Formulation & $\begin{array}{c}\text { WVP } \times 10^{7} \\
\left(\mathbf{g} \cdot \mathbf{m m} / \mathbf{k P a} \cdot \mathbf{h} \cdot \mathbf{m}^{2}\right)\end{array}$ & $\begin{array}{c}\text { OP } \times 10^{13} \\
\left(\mathbf{c m}^{3} / \mathbf{m}^{2} \cdot \text { día }\right)\end{array}$ & $\mathbf{X}_{\mathbf{w}}(\mathbf{g}$ water/g dry film) \\
\hline CCF & $6.9 \pm 0.2^{\mathrm{b}}$ & $1.26 \pm 0.03^{\mathrm{a}}$ & $12 \pm 3^{\mathrm{b}}$ \\
\hline CLZ & $8.2 \pm 0.5^{\mathrm{C}}$ & $1,19 \pm 0.02^{\mathrm{a}}$ & $14.0 \pm 0.2^{\mathrm{c}}$ \\
\hline CLAE & $5.0 \pm 0.6^{\mathrm{a}}$ & $2.08 \pm 0.07^{\mathrm{ab}}$ & $10.3 \pm 0.5^{\mathrm{a}}$ \\
\hline PCF & $15.1 \pm 1.3^{\mathrm{d}}$ & $2.51 \pm 0.02^{\mathrm{b}}$ & $10.3 \pm 0.6^{\mathrm{a}}$ \\
\hline PLZ & $17.6 \pm 0.9^{\mathrm{e}}$ & $1.99 \pm 0.16^{\mathrm{ab}}$ & $9.3 \pm 0.9^{\mathrm{a}}$ \\
\hline PLAE & $8.1 \pm 1.2^{\mathrm{C}}$ & $9.47 \pm 1.18^{\mathrm{C}}$ & $9.7 \pm 0.5^{\mathrm{a}}$ \\
\hline
\end{tabular}

Different letters (a, b, c, d, e) in the same column indicate significant differences among the different formulations $(p<0.05)$.

The barrier properties (WVP and OP) of the casting control films were similar to those previously reported for starch-gelatin casting films (Acosta et al., 2015). However, compression molded films exhibited significantly higher values of WVP and OP $(p<0.05)$ 
than casting films. For both film forming techniques, the incorporation of LZ reduced OP (6, $20 \%$, for $C$ and $P$ films) and increased WVP (19, $17 \%$, for $C$ and $P$ films). Contrarily, LAE significantly increased OP $(65,279 \%$ for $C$ and P films) and reduced WVP $(28,30$ $\%$, for $\mathrm{C}$ and $\mathrm{P}$ films) for both film types. This different response could be explained by the fact that the different structural properties and the induced changes in the hydrophilic character of the matrix (different water adsorption capacity) give rise to different transport rates for water and oxygen in the film. In this sense, compression molded films, exhibiting multiphasic structures with weak interphase adhesion, and being less compact than casting films, allowed for a greater degree of mass transport than casting films. The effect the processing method had on mechanical and barrier properties coincides with that previously reported by other authors for gelatin-starch films (Fakhoury et al., 2013).

The opposite effect of LZ and LAE on WVP and OP agrees with the previously mentioned reverse effect of these compounds on the water affinity of the films; whereas LZ enhanced the matrix hydrophilic character, LAE promoted its hydrophobicity. Consequently, water solubility in the matrix increases in LZ films, whereas oxygen solubility increases in LAE films, thus affecting the permeation behavior of each molecule in the matrix in an opposite way. Likewise, according to the multiphasic structure of the films, tortuosity factor for mass transport of permeants will also affect the mass transport rate (Pérez-Gagó and Krochta, 2001). Moreover, the obtained values for water vapour barrier properties of starch-gelatin blends were not in the established range of water vapour transmission rate for food systems' requirements ${ }^{31}$ and reduction would be necessary, which could be also obtained by cross linking strategies. Nevertheless, oxygen barrier properties of these films cover the whole range of food packaging requirements (Schmid et al., 2012).

\subsubsection{Film water solubility and swelling and migration capacity}

Figure 3.4 shows the values obtained for the water solubility and swelling capacity of the different samples, expressed as weight loss (\%) and water uptake (\%), respectively. Control films obtained by both casting and thermo-pressing methods (CCF and PCF) showed a similar water solubility to that reported by Fakhouri et al. (2013). Neither film composition nor the processing method led to significant changes in the film solubility. On the contrary, films obtained by casting exhibited a significantly greater water uptake $(p<0.05)$ (Figure 3.4). In all likelihood, the chain packing stemming from the drying of the film forming solutions is able to partially recover the hydrated form, binding a high water 
ratio, whereas the different polymer chain packing obtained from melt blending has a much lower water binding capacity in line with the development of different chain interactions at high temperatures without water. In addition, the loss of hydroxyl groups occurred during the caramelization process in compression molded films, could contribute to reduce the water uptake values. Both LZ (more markedly) and LAE enhanced the water uptake capacity of the casting films, whereas no significant effect was observed in compression molded films.

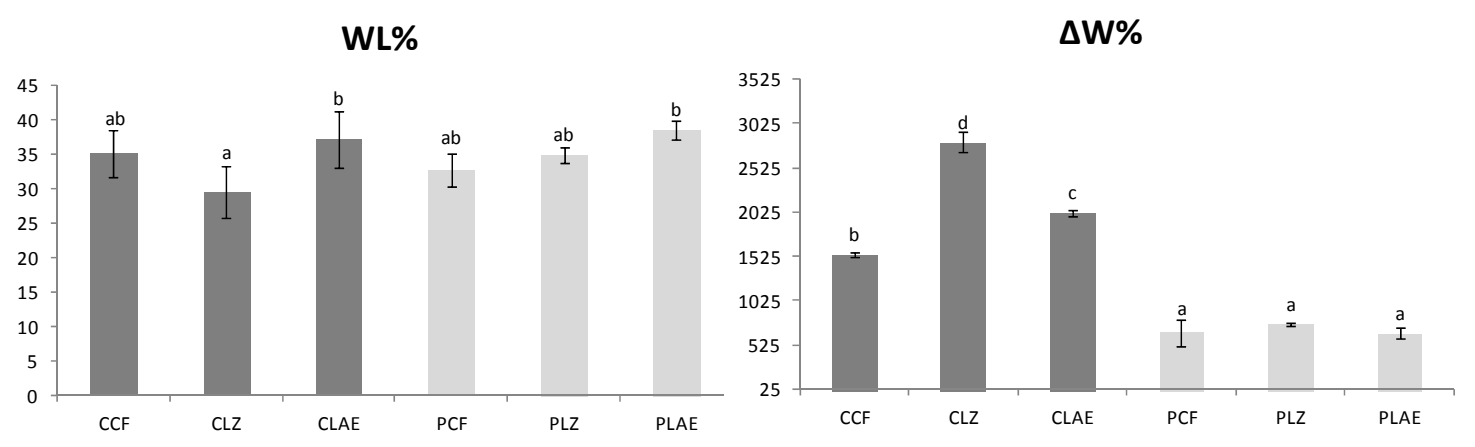

Figure 3.4 a) Weight loss of dried films (WL \%, g/100 g dried film) after $24 \mathrm{~h}$ of immersion in distilled water at $25^{\circ} \mathrm{C}$. Water uptake $(\Delta \mathrm{W} \%, \mathrm{~g}$ water/100 dried film) of the films after $24 \mathrm{~h}$ of immersion in distilled water at $25^{\circ} \mathrm{C}$. Average values and standard deviation. Different letters $(a, b, c, d)$ indicate significant differences among the different formulations.

Related with the solubility of the films in water systems such as foods, Table 3.4 shows the overall migration values obtained for the different films in water and some food simulants. For all the films, migration values in hydrophilic simulants (water, $10 \%$ ethanol and $3 \%$ acetic acid), exceeded the established limit for the overall migration of $10 \mathrm{mg} / \mathrm{dm}^{2}$ by the current law. In the most hydrophobic simulant (isooctane), films obtained by compression molding showed significantly lower overall migration values than those obtained by casting, meeting the established limit. When $10 \%$ ethanol was used, a different behavior was observed for casting and thermoprocessed films; casting films exhibited the lowest migration levels among all the hydrophilic simulants, these being closer to those obtained in isooctane, whereas thermoprocessed films showed the highest values. In general, the film processing mainly affected the the overall migration behavior of the films, while the addition of LZ or LAE slightly promoted the migration of film components in polar simulants. On the basis of these results, different strategies, 
such as a crosslinking process, would be required in order to reduce the migration capacity of the starch-gelatin films in aqueous food systems.

Table 3.4 Overall migration values $\left(\mathrm{mg} / \mathrm{dm}^{2}\right.$ ) of the different films (for 10 days at $20^{\circ} \mathrm{C}$ ) into different food simulants, distilled water, ethanol (10\% v/v) (simulant A), acetic acid

$(3 \% \mathrm{w} / \mathrm{v})($ simulant $\mathrm{B})$ and isooctane (simulant D2). Average values and standard deviation.

\begin{tabular}{lcccc}
\hline Formulation & Water & $\begin{array}{c}\text { Ethanol } \\
(\mathbf{1 0} \% \mathbf{v} / \mathbf{v})\end{array}$ & $\begin{array}{c}\text { Acetic acid } \\
(\mathbf{3} \% \mathbf{w / v})\end{array}$ & Isooctane \\
\hline CCF & $318 \pm 40^{\mathrm{a}, \mathrm{y}}$ & $108 \pm 15^{\mathrm{a}, \mathrm{x}}$ & $362 \pm 36^{\mathrm{a}, \mathrm{y}}$ & $47 \pm 24^{\mathrm{b}, \mathrm{x}}$ \\
CLZ & $394 \pm 84^{\mathrm{ab}, \mathrm{y}}$ & $212 \pm 46^{\mathrm{ab}, \mathrm{x}}$ & $673 \pm 35^{\mathrm{bc}, \mathrm{z}}$ & $79 \pm 8^{\mathrm{b}, \mathrm{x}}$ \\
\hline CLAE & $394 \pm 129^{\mathrm{ab}, \mathrm{xy}}$ & $348 \pm 52^{\mathrm{b}, \mathrm{xy}}$ & $622 \pm 148^{\mathrm{bc}, \mathrm{y}}$ & $126 \pm 99^{\mathrm{b}, \mathrm{x}}$ \\
\hline PCF & $598 \pm 14^{\mathrm{bc}, \mathrm{y}}$ & $713 \pm 16^{\mathrm{c}, \mathrm{z}}$ & $531 \pm 59^{\mathrm{ab}, \mathrm{y}}$ & $3 \pm 2^{\mathrm{a}, \mathrm{x}}$ \\
\hline PLZ & $793 \pm 29^{\mathrm{c}, \mathrm{yz}}$ & $853 \pm 7^{\mathrm{cd}, \mathrm{z}}$ & $774 \pm 42^{\mathrm{c}, \mathrm{y}}$ & $3 \pm 2^{\mathrm{a}, \mathrm{x}}$ \\
\hline PLAE & $735 \pm 164^{\mathrm{c}, \mathrm{y}}$ & $989 \pm 125^{\mathrm{d}, \mathrm{y}}$ & $982 \pm 51^{\mathrm{d}, \mathrm{y}}$ & $2 \pm 2^{\mathrm{a}, \mathrm{x}}$ \\
\hline
\end{tabular}

Different letters $(a, b, c, d)$ in the same column indicate significant differences among the different formulations for the same stimulant $(p<0.05)$.

Different letters $(x, y, z)$ in the same row indicate significant differences among the different simulants for the same formulation $(p<0.05)$.

\subsubsection{Thermogravimetric analysis}

Figure 3.5 shows the obtained thermograms for the different films and pure LZ and LAE. Likewise, in Table 3.5, the values of the initial degradation temperature $\left(T_{0}\right)$ and the temperature at the maximum degradation rate $\left(T_{\max }\right)$ for the different films and the pure active compounds are summarized. These results allow for the elucidation of the thermal stability of the material as a function of the composition, as well as the possible effect of thermal processing, as compared to casting films. The initial degradation temperatures of $\mathrm{LZ}$ and LAE were $217^{\circ} \mathrm{C}$ and $175^{\circ} \mathrm{C}$ respectively. These values are higher than the process temperature $\left(160^{\circ} \mathrm{C}\right)$, which offers some guarantees about their stability during the melt blending process. 

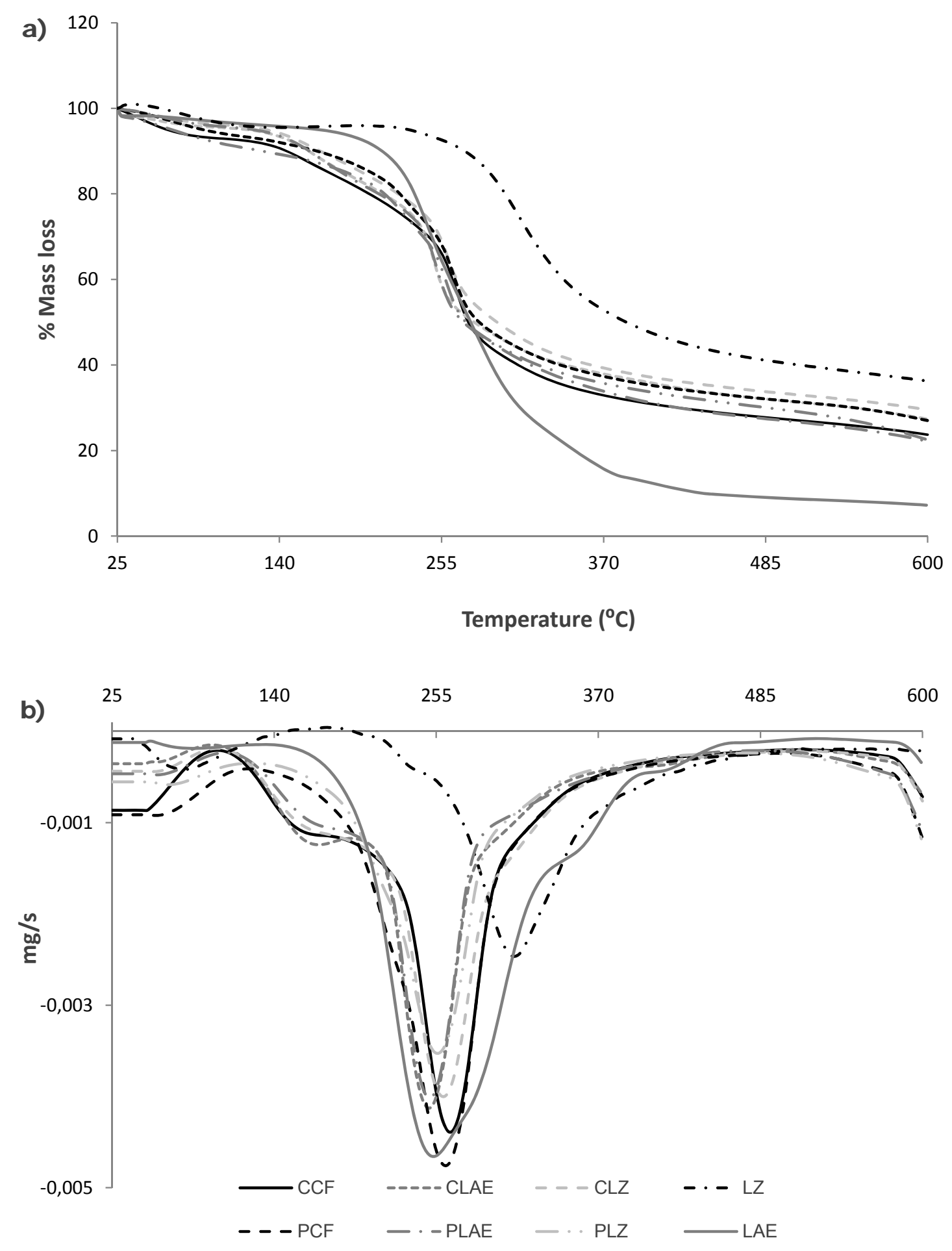

Figure 3.5 Thermogravimetric curves (a) and the first derivative of TGA curves (b) of the film samples and pure antimicrobial compounds ( $L Z$ and $L A E)$. 
Nevertheless, all the films obtained by compression molding, except PLAE, showed a $T_{0}$ value of around $160{ }^{\circ} \mathrm{C}$, whereas this was about $120^{\circ} \mathrm{C}$ for the rest of the films. This indicates that during the thermoprocessing at $160{ }^{\circ} \mathrm{C}$, some degradation compounds were formed from $120^{\circ} \mathrm{C}$ onwards, which may be responsible for the coloration of these films, as previously mentioned. The increase of $T_{0}$ for the films obtained by thermocompression indicates the different chemical composition attained by the materials after being partially degraded during the thermal process. It is remarkable that the thermocompressed films with LAE (PLAE), did not present significant browning, which is coherent with the lower $T_{0}$ value $\left(121^{\circ} \mathrm{C}\right)$ observed in the thermogram. This seems to indicate that there is some thermoprotective effect of this compound in the polymers during the melt blending process. The maximum degradation rate temperature of all the films was between $250^{\circ} \mathrm{C}$ and $260^{\circ} \mathrm{C}$; it was slightly lower both in films with bioactive compounds and, except for LAE formulation, in compression molded films.

Table 3.5 Onset $\left(T_{0}\right)$ and peak $\left(T_{\max }\right)$ (maximum degradation rate) temperatures for polymer degradation in the different films.

\begin{tabular}{lcc}
\hline Formulation & $\mathrm{T}_{\text {máx }}\left({ }^{\circ} \mathrm{C}\right)$ & $\mathrm{T}_{0}\left({ }^{\circ} \mathrm{C}\right)$ \\
\hline CCF & $264.75 \pm 0.11^{\mathrm{e}}$ & $119 \pm 4^{\mathrm{a}}$ \\
\hline CLZ & $260.09 \pm 0.12^{\mathrm{d}}$ & $124.8 \pm 0.7^{\mathrm{a}}$ \\
\hline CLAE & $249.9 \pm 0.4^{\mathrm{a}}$ & $123.5 \pm 1.7^{\mathrm{a}}$ \\
\hline PCF & $261.75 \pm 0.11^{\mathrm{d}}$ & $162.2 \pm 1.4^{\mathrm{b}}$ \\
\hline PLZ & $255.92 \pm 0.12^{\mathrm{c}}$ & $161.3 \pm 1.4^{\mathrm{b}}$ \\
\hline PLAE & $251.3 \pm 1.3^{\mathrm{a}}$ & $121.6 \pm 0.3^{\mathrm{a}}$ \\
\hline LAE & $253.8 \pm 1.1^{\mathrm{b}}$ & $175 \pm 4^{\mathrm{c}}$ \\
\hline LZ & $310.7 \pm 1.6^{\mathrm{f}}$ & $217 \pm 7^{\mathrm{d}}$ \\
\hline
\end{tabular}

Different letters $(a, b, c, d, e, f)$ in the same column indicate significant differences among the different formulations $(p<0.05)$.

On the basis of these results and the optical analysis, thermal processing of starchgelatin blends could not represent a good strategy to obtain films due to the occurrence of some degradation reactions, which give rise to dark brown discoloration of the films. Nevertheless, LAE incorporation implied a certain protection against these browning reactions. 


\subsection{Antilisterial properties of the films and Lysozyme activity}

Table 3.6 shows the results obtained from the analysis of the films' antimicrobial activity. The films with LAE (both CLAE and PLAE) had an absolute bactericidal effect at every control time. On the other hand, none of the formulations with LZ exhibited antilisterial activity, in spite of its notable enzyme activity $(21.803 \pm 2.378 \mathrm{U} / \mathrm{mg})$, determined through the absorbance reduction caused by the lysis of Micrococcus lysodeikticus (Fabra et al., 2014). This could be attributed to the immobilization of LZ in the starch-gelatin matrix, which could limit its diffusion from the film surface, taking into account its high molecular weight (14.4 kDa). Therefore, its potential antimicrobial activity would be inhibited.

Table 3.6 Effect of the films on the growth and survival of Listeria innocua (CECT 910) at $37^{\circ} \mathrm{C}$. Bacterial counts obtained at initial time $(0 \mathrm{~h}), 5$ and $24 \mathrm{~h}$ of incubation. Average values and standard deviation.

\begin{tabular}{lccc}
\hline \multirow{2}{*}{ Formulation } & $\mathbf{0 ~ h}$ & $\mathbf{5 ~ h}$ & $\mathbf{2 4} \mathbf{~}$ \\
\cline { 2 - 4 } & $\log \left(\mathbf{C F U} / \mathbf{c m}^{2}\right)$ & $\log \left(\mathbf{C F U} / \mathbf{c m}^{2}\right)$ & $\log \left(\mathbf{C F U} / \mathbf{c m}^{2}\right)$ \\
\hline Ci $^{\star *}$ & $2.08 \pm 0.07^{\mathrm{a}, \mathrm{x}}$ & $3.91 \pm 0.05^{\mathrm{b}, \mathrm{y}}$ & $7.35 \pm 0.02^{\mathrm{b}, \mathrm{z}}$ \\
CCF & $2.14 \pm 0.04^{\mathrm{b}, \mathrm{x}}$ & $4.19 \pm 0.03^{\mathrm{c}, \mathrm{y}}$ & $7.40 \pm 0.05^{\mathrm{b}, \mathrm{z}}$ \\
\hline CLZ & $2.13 \pm 0.03^{\mathrm{ab}, \mathrm{x}}$ & $4.18 \pm 0.03^{\mathrm{c}, \mathrm{y}}$ & $7.40 \pm 0.03^{\mathrm{b}, \mathrm{z}}$ \\
CLAE & $\mathrm{NDG}^{*}$ & $\mathrm{NDG}^{*}$ & $\mathrm{NDG}^{*}$ \\
PCF & $2.25 \pm 0.02^{\mathrm{c}, \mathrm{x}}$ & $3.86 \pm 0.08^{\mathrm{b}, \mathrm{y}}$ & $7.35 \pm 0.04^{\mathrm{b}, \mathrm{z}}$ \\
\hline PLZ & $2.13 \pm 0.02^{\mathrm{ab}, \mathrm{x}}$ & $3.77 \pm 0.06^{\mathrm{a}, \mathrm{y}}$ & $7.24 \pm 0.07^{\mathrm{a}, \mathrm{z}}$ \\
\hline PLAE & $\mathrm{NDG}^{*}$ & $\mathrm{NDG}^{*}$ & $\mathrm{NDG}^{*}$ \\
\hline
\end{tabular}

Different letters $(a, b, c, d, e)$ in the same column indicate significant differences among the different formulations $(p<0.05)$.

Different letters $(x, y, z)$ in the same row indicate significant differences among the different times of incubation for the same formulation $(p<0.05)$.

\footnotetext{
${ }^{*}$ No Detected Growth.

** Inoculum Control.
} 


\section{CONCLUSIONS}

W

hereas the incorporation of LAE to starch-gelatin blend films was very effective at imparting active (antilisterial) properties to the material, LZ did not confer notable antibacterial activity on the films. LAE also improved the interfacial adhesion of the polymers in both casting and thermoprocessing methods, making the blending process easier. The incorporation of LAE notably reduced stiffness and resistance to break in casting films, making them more extensible, which was only observed for $L Z$ in the case of the casting method. Likewise, LAE promoted water vapor barrier properties and increased the oxygen permeability of the films, although the latter was in the range of food packaging requirements. Likewise, this antimicrobial compound enhanced the thermal stability of the blends, which is highly positive for thermoplastic processing at industrial level. Therefore, as it is a promising compound when formulating biodegradable active films obtained by either casting or thermal processing, its incorporation into starch-gelatin films greatly enhanced their functionality and added value. Nevertheless, due to the fact that there is a high degree of overall migration of the films to hydrophilic food simulants, different strategies, such as the crosslinking process, would be required to limit this aspect.

\section{Acknowledgements}

The authors acknowledge the financial support provided by the Ministerio de Economía y Competividad (Projects AGL2013-42989-R) and the services rendered by the Electron Microscopy Service of the UPV. Olga Moreno Marro also thanks the Ministerio de Educación, Cultura y Deporte for the FPU 2012-1121 grant. 


\section{REFERENCES}

Acosta, S., Jiménez, A., Cháfer, M., González-Martínez, C., Chiralt, A. (2015) Physical properties and stability of starch-gelatin based films as affected by the addition of esters of fatty acids. Food Hydrocolloids, 49, 135-143.

Al-Hassan, A. A., Norziah, M. H. (2012) Starch-gelatin edible films: Water vapor permeability and mechanical properties as affected by plasticizers. Food Hydrocolloids, 26, (1) 108-117.

ASTM. (1995). Standard test methods for water vapour transmission of materials. In Standard designations: E96-95 annual book of ASTM standards. Philadelphia, PA: American Society for Testing and Materials.

ASTM. (1999). Standard test methods for specular gloss. Designation (D523): Annual book of ASTM standards (Vol. 06.01) Philadelphia, PA: American Society for Testing and Materials.

ASTM. (2001). Standard test method for tensile properties of thin plastic sheeting. In Standard D882 annual book of American Standard Testing Methods. Philadelphia, PA: American Society for Testing and Materials. ASTM.

ASTM. (2005). Standard test method for oxygen gas transmission rate through plastic film and sheeting using a coulometric sensor. In Standard designation: D3985-05:annual book of American Society for Testing Materials. West Conshohocken, PA: ASTM.

Atarés, L., Bonilla, J., Chiralt, A. (2010). Characterization of sodium caseinate-based edible films incorporated with cinnamon or ginger essential oils. Journal of Food Engineering, 100, 678-687.

Balaguer, M. P., Gómez-Estaca, J., Gavara, R., \& Hernandez-Munoz, P. (2011). Biochemical properties of bioplastics made from wheat gliadins cross-linked with cinnamaldehyde. Journal of agricultural and food chemistry, 59(24), 13212-13220.

Barnett, I., (2011). Packaging Solutions Throughout the Supply Chain: Technology, Trends and Future Outlook. Business Insight, London.

Bayarri, M., Oulahal, N., Degraeve, P., Gharsallaoui, A., (2014), Properties of lysozyme/lo methoxyl (LM) pectin complexes for antimicrobial edible food packaging, Journal of Food Engineering. 131, 18-25.

Corradini, C., Alfieri, I., Cavazza, A., Lantano, C., Lorenzi, A., Zucchetto, N., Montenero, A., (2013) Antimicrobial films containing lysozyme for active packaging obtained by solgel technique. Journal of Food Engineering, 119, 580-587. 
European Commission. (2011). Commission Regulation (EU) No 10/2011 of 14 January 2011 on plastic materials and articles intended to come into contact with food. Off Journal of European Commission, 50, 1-89.

Fabra, M.J., Sánchez-González, L., Chiralt, A. (2014). Lysozyme release from isolate pea protein and starch based films and their antimicrobial properties. LWT - Food Science and Technology, 55, 22-26.

Fakhoury, F. M., Martelli, S. M., Bertan, L. C., Yamashita, F., Innocentini Mei, L. H., Collares Queiroz, F.P. (2012). Edible films made from blends of manioc starch and gelatin e Influence of different types of plasticizer and different levels of macromolecules on their properties. Food Science and Technology, 49, 149-154.

Fakhoury, F. M., Costa, D., Yamashita, F., Martelli, S. M., Jesus, R. C., Alganer, K., Collares-Queiroz, F. P., Innocentini-Mei, L. H. (2013) Comparative study of processing methods for starch/gelatin films. Carbohydrate Polymers, 95, 681- 689.

Güçbilmez, Ç. M., Yemenicioğlu, A., \& Arslanoğlu, A. (2007). Antimicrobial and antioxidant activity of edible zein films incorporated with lysozyme, albumin proteins and disodium EDTA. Food research international, 40(1), 80-91.

Hawkins, D.R., Rocabayera, X., Ruckman, S., Segret, R., Shaw, D. (2009). Metabolism and pharmacokinetics of ethyl Na-lauroyl-L-arginate hydrochloride in human volunteers. Food and Chemical Toxicology, 47, 2711-2715.

Higueras, L., López-Carballo, G., Hernández-Muñoz, P., Gavara, R., Rollini, M. (2013) Development of a novel antimicrobial film based on chitosan with LAE (ethyl-Nadodecanoyl-L-arginate) and its application to fresh chicken. International Journal of Food Microbiology, 165, 339-345.

Hutchings, J.B., 1999. Food colour and appearance. Aspen Publishers, Maryland.

Ibrahim, H. R., Higashiguchi, S., Koketsu, M., Juneja, L. R., Kim, M., Yamamoto, T (1996). Partially unfolded lysozyme at neutral $\mathrm{pH}$ agglutinates and kills Gram-negative and Gram positive bacteria through membrane damage mechanism. Journal of Agricultural and Food Chemistry, 44, 3799-3806.

Jiménez, A., Fabra, M. J., Talens, P., Chiralt, A. (2012) Edible and Biodegradable Starch Films: A Review. Food Bioprocess Technology, 5, 2058-2076.

McHugh, T. H., Avena-Bustillos, R., Krochta, J. M. (1993). Hydrophobic edible films: modified procedure for water vapor permeability and explanation of thickness effects. Journal of Food Science, 58(4), 899-903.

Moreno, O., Pastor, C., Muller, J., Atarés, L., González, C., Chiralt, A. (2014) Physical and bioactive properties of corn starch - Buttermilk edible films. Journal of Food Engineering, 141, 27-36.

Muriel-Galet, V., López-Carballo, G., Hernández-Muñoz, P., \& Gavara, R. (2014). Characterization of ethylene-vinyl alcohol copolymer containing lauril arginate (LAE) as 
material for active antimicrobial food packaging. Food packaging and shelf life, 1(1), $10-$ 18.

Muriel-Galet, V., López-Carballo, G., Gavara, R., Hernández-Muñoz, P. (2015) Antimicrobial Effectiveness of Lauroyl Arginate Incorporated into Ethylene Vinyl Alcohol Copolymers to Extend the Shelf-Life of Chicken Stock and Surimi Sticks. Food Bioprocess Technol, 8, 208-217.

Ortega-Toro, R., Jiménez, A., Talens, P., Chiralt, A. (2014) Properties of starchhydroxypropyl methylcellulose based films obtained by compression molding. Carbohydrate Polymers 109, 155-165

Pérez-Gago, M. B., \& Krochta, J. M. (2001). Lipid particle size effect on water vapor permeability and mechanical properties of whey protein/beeswax emulsion films. Journal of agricultural and food chemistry, 49(2), 996-1002.

Rodríguez, E., Seguer, J., Rocabayera, X., Manresa., A. (2004) Cellular effects of monohydrochloride of L-arginine, Na-lauroyl ethylester (LAE) on exposure to Salmonella typhimurium and Staphylococcus aureus. Journal of Applied Microbiology. 96, 903-912.

Schmid, M., Dallmann, K., Bugnicourt, E., Cordoni, D., Wild, F., Lazzeri, A., \& Noller, K. (2012). Properties of whey-protein-coated films and laminates as novel recyclable food packaging materials with excellent barrier properties. International Journal of Polymer Science, 8, 1-7.

Shugar, D. (1952) The measurement of lysozyme activity and the ultra-violet inactivation of lysozyme. Biochimica et Biophysica Acta, 8, 302-309.

Tharanathan R., (2003). Biodegradable films and composite coating: past, present and future. Critical Review in Food Science and Technology, 14, 71-78.

Wilhelm, H.-M., Sierakowski , M.-R., Souza, G.P., Wypych, F. (2003) Starch films reinforced with mineral clay. Carbohydrate Polymers, 52, 101-110. 


\section{CHAPTER 4}

\section{INFLUENCE OF STARCH OXIDATION ON THE \\ FUNCTIONALITY OF STARCH- GELATIN BASED ACTIVE FILMS}

\section{Olga Moreno*, Julián, Cárdenas, Lorena Atarés, Amparo Chiralt.}

Departamento de Tecnología de Alimentos - Instituto de Ingeniería de Alimentos para el Desarrollo. Universitat Politècnica de València, Camino de Vera s/n 46022 Valencia, Spain 


\section{ABSTRACT}

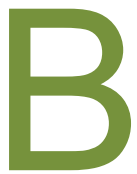

iodegradable active films were prepared using corn starch, with a different degree of oxidation, bovine gelatin, glycerol, as a plasticizer, and ethyl lauroyl arginate (LAE) as antimicrobial compound. The films were obtained by casting and characterised as to their microstructure, polymer crosslinking, tensile, barrier and optical properties and water solubility and uptake capacity. Starch oxidation with sodium periodate greatly improved polymer compatibility, promoting the polymer crosslinking. This was enhanced when 1:1 glucose:periodate molar ratio was used for starch oxidation. Crosslinking promoted the films' strength and barrier capacity, while Maillard reactions gave rise to the formation of brown compounds. When LAE was incorporated in the film formulation, its bifunctional nature (with amino and carbonyl groups) led to its participation in the condensation reactions, which interfered in the network crosslinking, especially when starch chains were partially oxidised. Browning reactions and crosslinking progressed throughout storage time, enhancing the films' stiffness and colouring.

KEYWORDS: biodegradable active films, oxidized corn starch, bovine gelatin, LAE, crosslinking. 


\section{INTRODUCTION}

owadays, most of the food packaging systems are based on petroleum-derived

synthetic plastics, whose production has increased exponentially over the past two decades (Tharanthan, 2003). Nevertheless, the utilization of these materials involves a serious environmental problem and high recycling costs (Moreno et al., 2014). In order to deal with this issue, current research focuses on the development of biodegradable polymers from renewable sources (Byun and Kim, 2014; Cazón, 2016).

Of the natural polymers available, starch is one of the most promising polysaccharides, since it is an abundant, low cost edible material (Barnett, 2011; Cazón, 2016, Moreno et al., 2015) and capable of being processed by the usual treatments applied in synthetic materials (Moreno et al., 2016). Native starch becomes thermoplastic (TPS) when thermally treated with plasticizers, which reduces the melting temperature below that of decomposition, thus allowing it to be moulded into a determined shape (Jiménez et al., 2012). However, TPS films also show some drawbacks when compared to oil-derived synthetic polymers, such as its highly hydrophilic nature, giving rise to water sensitivity and a poor water vapour barrier capacity. Starch retrogradation is also an inconvenience due to the fact that its mechanical properties worsen throughout storage (Ortega-Toro et al., 2014).

Properties of TPS films have been improved by blending with other biopolymers. More specifically, blends with gelatin have been previously reported to yield films with improved resistance and elongation capacity (Acosta et al., 2015; Fakhoury et al., 2012). Moreno et al. (2016) obtained starch-gelatin based films by thermo-processing and found no improvement in the water sensitivity, which suggests the need for developing new strategies to produce more hydrophobic starch matrices, or crosslinking processes which enhance the functionality of the starch material. In this sense, the oxidation of starch, giving rise to dialdehyde formation (DAS), can be used to promote the crosslinking capacity of the chains, while increasing the hydrophobicity of the matrix. During the oxidizing process, an oxidative cleavage of C-2 and C-3 bond of the anhydroglucose units of the native starch is produced (Yu et al., 2010, Du et al., 2008), yielding a reduction in hydroxyl groups to form carboxyl and carbonyl groups. The condensation reaction between carbonyl and amino groups also enables DAS to act as 
crosslinking agent with proteins (Rhim et al., 1998; Wang et al., 2015). In this way, the reinforcement of the inner matrix may improve the mechanical behaviour and water resistance of the films. Rhim et al. (1998) observed improved rigidity, resistance to fracture and extensibility, as well as reduced water solubility, when DAS was added to soy protein films (5:100 mass ratio). On the other hand, the reaction between carbonyls of reducing sugars and protein amino groups led to the formation of Maillard compounds, thus resulting in film browning. The increase in the number of carbonyl groups reduced the thermal stability of DAS (Soliman et al., 1997; Zhang et al., 2007), which can compromise the thermoprocessing of DAS-gelatin blends. Heating DAS-gelatin blends could, hence, extend the reaction between both polymers, resulting in an unsuitable material.

On the other hand, the inner reinforcement of the matrix induced by the crosslinking effect could enhance the retention of bioactive compounds, leading to a more controlled release when applied to foodstuffs. The incorporation of ethyl lauroyl arginate (N- $\alpha-$ lauroyl-I-arginine ethyl ester monohydrochloride, LAE) into DAS-gelatin films, can provide them with antimicrobial properties, while introducing more amino and carbonyl groups in the system. LAE is a potent food antimicrobial agent, derived from lauric acid, L-arginine, and ethanol with a wide spectrum of antimicrobial activity, even at low concentrations (Muriel-Galet et al., 2014). LAE has been reported to cause cell growth inhibition or death by increasing the permeability of the cell membrane, as a consequence of the membrane protein denaturation (Rodriguez et al., 2004). Thus, LAE is a promising antimicrobial additive considered as GRAS (Generally recognized as safe) by the FDA, and accepted as food additive E243 in Europe (Hawkins et al., 2009; Higueras et al., 2013).

The present study aims to evaluate the effect of different degrees of starch oxidation and LAE incorporation on the functional properties of starch-gelatin blend films, obtained by casting method. The crosslinking effect in oxidized starch-gelatin matrices was assessed in comparison with non-oxidized starch. Moreover, the tensile and optical properties and barrier capacity to water vapour after 5 weeks of storage were analysed in order to evaluate the development of the crosslinking effect throughout time. 


\section{MATERIALS AND METHODS}

\subsection{Materials}

The following materials were employed to obtain the films: Corn starch (CS) (Roquette Laisa España, S.A., Valencia, Spain); Bovine gelatin type A (BG) (Sancho de Borja, S.L., Zaragoza, Spain); Sodium periodate (SP) (Fluka Analytical, Sigma-Aldrich Chemie $\mathrm{GmbH}$, Steinheim, Germany); Ethyl lauroyl arginate (LAE) at $10 \% \mathrm{w} / \mathrm{v}$ in ethanol (Vedeqsa, Lamirsa, Terrassa, Spain) and glycerol as plasticizer (Panreac Química S.A., Castellar de Vallès, Barcelona, Spain).

The reagents used for film conditioning (magnesium nitrate or phosphorus pentoxide) and overall migration test (ethanol, acetic acid and isooctane) were all supplied by Panreac Química S.A., Castellar de Vallès, Barcelona, Spain.

\subsection{Oxidation of Starch}

The oxidation of CS was carried out by using SP as oxidizing reagent following a modification of the method described by Wang et al. (2015). CS was dispersed and gently stirred $(10 \% \mathrm{w} / \mathrm{v})$ in distilled water, then, SP was added obtaining two different SP:Glucose unit molar ratios (1 or 0.5 ), to obtain two different oxidation ratios (OR_0.5 and OR_1.0) in the starch samples. The reaction was kept in the dark for four hours at $35^{\circ} \mathrm{C}$. The solution reached a value of $\mathrm{pH} 3.5$ once the components were mixed. Both OS samples were washed with distilled water three times, while being homogenised with a rotor stator homogenizer, Ultraturrax (T25, Janke and Kunkel, Germany) at 8,000 rpm for 30 seconds, and subsequently vacuum filtered (MZ 2C NT, Vacuubrand GMBH + CO KG, Wertheim, Germany). The final solids obtained were used for film preparation, taking into account the water content, which was determined by desiccating both samples in a vacuum oven $\left(60^{\circ} \mathrm{C}-24 \mathrm{~h}\right)$, and then stored in desiccators with $\mathrm{P}_{2} \mathrm{O}_{5}$ until constant weight was reached. 


\subsection{Film preparation}

Six formulations, based on starch and gelatin (mass ratio 1:1), were obtained, employing glycerol as plasticizer: three control formulations with oxidised or non-oxidised starch (OR_0, OR_0.5, OR_1) and three active formulations containing LAE (OR_OLAE, OR_0.5LAE, OR_1LAE).

The preparation of the films was carried out using the casting method, by blending two separate dispersions of both starch and gelatin in distilled water ( $2 \%$ wt.). All of the starch dispersions were homogenized in a rotor stator homogenizer, Ultraturrax, for 1 minute at $8,000 \mathrm{rpm}$, to ensure a complete dispersion of the compound. Then, to induce starch gelatinization, OR_0, OR_0.5 and OR_1 dispersions were immersed in a thermostatic bath at $100^{\circ} \mathrm{C}$, for 30,45 or 60 min, respectively, and cooled down to room temperature. Additionally, BG dispersion was prepared with magnetic stirring (30 min at $40{ }^{\circ} \mathrm{C}$ ). Both starch and BG dispersions were mixed in the correct proportion to obtain the control films (OR_0, OR_0.5, OR_1), with the incorporation of glycerol in a polymer:glycerol mass ratio of $1: 0.25$. Moreover, in order to obtain the active films (OR_0, OR_0.5LAE, OR_1LAE) LAE was added in a polymer:LAE mass ratio of 1:0.1. All of the film-forming formulations were kept under magnetic stirring for $30 \mathrm{~min}$, and then, the right amount was poured into Teflon plates (150 mm diameter) to assess $1.5 \mathrm{~g}$ of dry solids on each plate, corresponding to $84 \mathrm{~g}$ dry solids $/ \mathrm{dm}^{2}$. After drying for $48 \mathrm{~h}$ at $45 \% \mathrm{RH}$ and $25^{\circ} \mathrm{C}$, the films were separated from the plates and stored for one and five weeks at $25{ }^{\circ} \mathrm{C}$ and $53 \% \mathrm{RH}$ (in desiccators with saturated solutions of magnesium nitrate) prior to analyses.

\subsection{Microstructural and physical characterization of films.}

\subsubsection{Film microstructure.}

The film samples were conditioned in desiccators containing $\mathrm{P}_{2} \mathrm{O}_{5}$ for $48 \mathrm{~h}$ in order to eliminate the water content; then, the films were immersed in liquid nitrogen to obtain cryfractured cross sections. All of the samples were mounted on cupper stubs and, after platinum coating, images of the films' cross section were obtained by Field Emission Scanning Electron Microscopy (FESEM), using a ZEISS $®$, model ULTRA 55 (Germany) Microscope. An accelerating voltage of $2 \mathrm{kV}$ was used for the observation. 


\subsubsection{Tensile properties and thickness}

The tensile behaviour of the films was determined following the standard method ASTM D882 (2001). Prior to every test, the films were conditioned at $53 \% \mathrm{RH}$ for one and five weeks to evaluate the crosslinking effect throughout time. A texture analyzer (TA-XTplus, Stable Micro Systems, Surrey, United Kingdom) was employed to obtain the stressstrain curves and the following parameters were determined: Elastic modulus (EM, $\mathrm{MPa}$ ), tensile strength (TS, MPa) and elongation at break (\% E). Firstly, the thickness of all of the film formulations was measured at four different points by using a hand-held digital micrometer (Electronic Digital Micrometer, Comecta S.A., Barcelona, Spain). Then, film stripes ( $25 \mathrm{~mm}$ wide, $100 \mathrm{~mm}$ long) were mounted in the film extension grips and stretched at $50 \mathrm{~mm} \mathrm{~min}^{-1}$ until breaking. 12 replicates per formulation were run.

\subsubsection{Water content and barrier properties of the films.}

The moisture of the film samples, conditioned at $53 \% \mathrm{RH}$, was determined by applying a two-step gravimetric method. Firstly, the samples were desiccated in a vacuum oven (60 ${ }^{\circ} \mathrm{C}-24 \mathrm{~h}$ ) and, secondly, stored in desiccators with $\mathrm{P}_{2} \mathrm{O}_{5}$ until constant weight was reached. The final results were expressed as $\mathrm{g}$ of water per $100 \mathrm{~g}$ of dry film. Six replicates per formulation were considered.

The water vapour permeability (WVP) of the films was determined according to Mc Hugh et al. (1993), following a modification of the ASTM E96-95 gravimetric method (1995). Prior to the test, the thickness of all the samples was measured at six points, as described above. Round film samples (35mm diameter) of each formulation were secured on Payne permeability cups (Elcometer SPRL, Hermelle/s Argenteau, Belgium), with the outwards-facing side in contact with the air during drying. Before securing the films, $5 \mathrm{~mL}$ distilled water was placed (100\% RH) inside each cup, and then the cups were placed inside desiccators containing an oversaturated magnesium-nitrate solution in order to generate $53 \% \mathrm{RH}$. Each pre-equilibrated cabinet was fitted with a fan to provide a strong driving force across the film for water vapour diffusion. The cabinets were stored at $25{ }^{\circ} \mathrm{C}$, weighing the cups periodically $( \pm 0.00001$, ME36S Sartorius, Germany) every $1.5 \mathrm{~h}$, until steady state had been reached (24 h). Four replicates per formulation were considered. 
The oxygen permeability (OP) of the films was determined following the standard method ASTM D3985-95 (2005). Measurements were taken using an OX-TRAN (Model 2/21 ML Mocon Lippke,Neuwied, Germany), at $53 \% \mathrm{RH}$ and $25^{\circ} \mathrm{C}$ and $50 \mathrm{~cm}^{2}$ exposed area. The films were exposed to pure nitrogen flow on one side and pure oxygen flow on the other side. The OP was calculated by dividing the oxygen transmission rate by the difference in oxygen partial pressure between the two sides of the film, and multiplying by the average film thickness, which was measured at six points before the test. Two replicates per formulation were made.

\subsubsection{Optical properties.}

The infinite reflectance spectra $\left(R_{\infty}\right)$ of the film samples $(400$ to $700 \mathrm{~nm}$ ) was obtained with a spectrocolorimeter MINOLTA, model CM-3600d (Minolta CO, Tokyo, Japan), measuring on the side of the films facing the air during drying. To this end, the measurements were taken on both black $(R 0)$ and white $(R)$ backgrounds. Additionally, the spectrum of the white background was measured $(\mathrm{Rg})$. Once all the spectra were obtained, the internal transmittance of the films (Ti), an indicator of the transparency, was calculated, using the Kubelka-Munk theory (Hutchings, 1999) for multiple scattering. The same theory allowed $R_{\infty}$, (reflectance for an infinite film thickness) to be obtained, which was used to calculate the CIE-L*a*b* parameters (CIE, 1986), using illuminant D65 and observer $10^{\circ}$. The colour coordinates $L^{*}$ (lightness), $C_{a b}{ }^{*}$ (chrome) and $h_{a b}{ }^{*}$ (hue) were calculated according to Atarés et al. (2010). Six samples per formulation were measured.

\subsubsection{Film solubility and swelling in water.}

A modification of the method described by Balaguer et al., (2011) was applied to determine the solubility and swelling (water uptake capacity) of the films. Film samples were cut into $3 \times 3 \mathrm{~cm}$ squares and dried for 2 weeks in desiccators over $\mathrm{P}_{2} \mathrm{O}_{5}$ in order to reduce the water content to practically zero. Firstly, the initial dry weight $\left(\mathrm{W}_{d}{ }^{i}\right)$ of the samples was taken, and then the dry films were immersed in $10 \mathrm{~mL}$ of distilled water in glass containers, gently stirred and kept in contact for $24 \mathrm{~h}$ at $25^{\circ} \mathrm{C}$. Directly afterwards, the solvent was poured in a filter, retaining the film sample, the remaining surface water was removed and the final wet weight $\left(\mathrm{W}_{\mathrm{w}}{ }^{\mathrm{f}}\right)$ was measured. These wet samples were dried till constant weight to evaluate the mas of residual solids in the film after soaking 
$\left(W_{d}^{f}\right)$. The solubility of the films was expressed as the weight loss (WL \%, g/g dry film) of the samples (Equation 4.1), while the water update capacity $(\Delta \mathrm{W} \%, \mathrm{~g}$ water/g dry film) was calculated by Equation 4.2. Four replicates per formulation were considered.

$$
\begin{aligned}
& W L \%=\frac{W_{d}^{i}-W_{d}^{f}}{W_{d}^{i}} \cdot 100 \\
& \Delta W \%=\frac{W_{w}^{f}-W_{d}^{f}}{W_{d}^{f}} \cdot 100
\end{aligned}
$$

(Equation 4.2)

\subsubsection{Overall migration}

The overall migration of the films conditioned for 1 week at $53 \% \mathrm{RH}$ was determined according to the current legislation (Commission Regulation (EU) No 10/2011). Film samples were immersed in $50 \mathrm{~mL}$ of simulant, keeping a contact ratio of $6 \mathrm{dm}^{2}$ of sample/kg of simulant. Three food simulants were used: Simulant $A$ (ethanol $10 \% \mathrm{v} / \mathrm{v}$, simulating hydrophilic foods), simulant B (acetic acid $3 \% \mathrm{w} / \mathrm{v}$, simulating hydrophilic acid foods) and simulant D2 (isooctane, simulating lipophilic foods, with free fats at the surface). All the samples were kept in contact with the simulants for 10 days at $20{ }^{\circ} \mathrm{C}$ (test number OM1). Directly after the contact time, the film samples were removed from the simulants, which were evaporated until dry. Finally, the obtained residue was weighed and the results were expressed as milligrams of the total constituents released per $\mathrm{dm}^{2}$ of contact surface $\left(\mathrm{mg} / \mathrm{dm}^{2}\right)$. All of the tests were run in duplicate.

\subsection{Thermogravimetric analysis (TGA)}

The films were characterized as to their thermal stability using a thermogravimetric analyzer (TGA/SDTA 851e, Mettler Toledo, Schwerzenbach, Switzerland). Each sample film (about $3 \mathrm{mg}$ ) was heated from room temperature to $600{ }^{\circ} \mathrm{C}$, under nitrogen flow $(50$ $\mathrm{mL} / \mathrm{min}$ ), at $10^{\circ} \mathrm{C} / \mathrm{min}$. Two replicates per formulation were obtained. 


\subsection{ATR FTIR Spectroscopy analysis}

The attenuated total reflectance (ATR) FTIR spectra of the different films were obtained in a Thermo Nicolet 5700 Fourier transform infrared spectrometer (FTIR). The average spectra were collected from 64 accumulations with a resolution of $4 \mathrm{~cm}^{-1}$ in the $4000-400$ $\mathrm{cm}^{-1}$ range, from five different locations of the same specimen.

\subsection{Statistical analysis}

The statistical analysis of the data was performed through an analysis of variance (ANOVA) using Statgraphics Centurion XVI s for Windows 5.1 (Manugistics Corp., Rockville, Md.).

\section{RESULTS AND DISCUSSION}

\subsection{Microstructure and crosslinking analysis in the films.}

The effect of starch oxidation on the blend film's structure and the crosslinking process has been assessed through the analysis of the film's microstructure, FTIR spectra and thermal behaviour (thermogravimetric analysis: TGA). Films of oxidised starch (DAS) with differing degrees of oxidation $(0,0.5$ and 1.0) were included in the FTIR and TGA analysis to better understand interactions in starch-gelatin films.

\section{FESEM analysis}

FESEM cross section images obtained for starch-gelatin blend films, with differing degrees of oxidation, with and without LAE, are shown in Figure 4.1. In films with a nonoxidised starch, polymer separation can be observed during drying, the film exhibiting a gelatin-rich layer at the top and a starch-rich layer at the bottom, depending on their 
differing densities, as previously reported by Moreno et al. (2016). An oxidation treatment of the starch seems to improve the polymer compatibility by enhancing interactions between starch and gelatin chains; no clearly separated layers were observed in the films with differing degrees of starch oxidation, showing a greater integration between both polymers. The enhanced cross linking ability provided by OS also led to a smother surface fracture in the cross section images of the films, especially for the OR_1 sample, with the highest degree of oxidation.

The incorporation of LAE favoured the polymer compatibility in non-oxidised starch, giving rise to a different film microstructure with small domains of both polymers due to the LAE surfactant action; thus avoiding polymer stratification during the film drying step, as reported by Moreno et al. (2016). With oxidized starch, films containing LAE showed a very smooth fracture surface, thus indicating the good compatibility achieved by all the components. Only small voids could be appreciated in the matrix, which can be attributed to the presence of very small air bubbles incorporated during the homogenization step of the film-forming dispersion. The surfactant effect of LAE promotes air incorporation and the high degree of viscosity of the film-forming dispersion makes its elimination difficult. Microscopic observations revealed a much more homogenous film structure when oxidised starch was used in the starch-gelatin film formulation, which was clearly enhanced by LAE addition. In this case, separate polymer domains were not observed and a cohesive structure without discontinuities could be appreciated. This suggests LAE participation in the polymer network, through its interaction/reaction with the new side groups of starch chains. The LAE molecule has two primary amino groups that are highly reactive with the carbonyls of oxidised starch and also two carbonyls which are potentially reactive with the amino groups of protein. Therefore, the participation of LAE in polymer bonding could be expected on the basis of its molecular structure. 

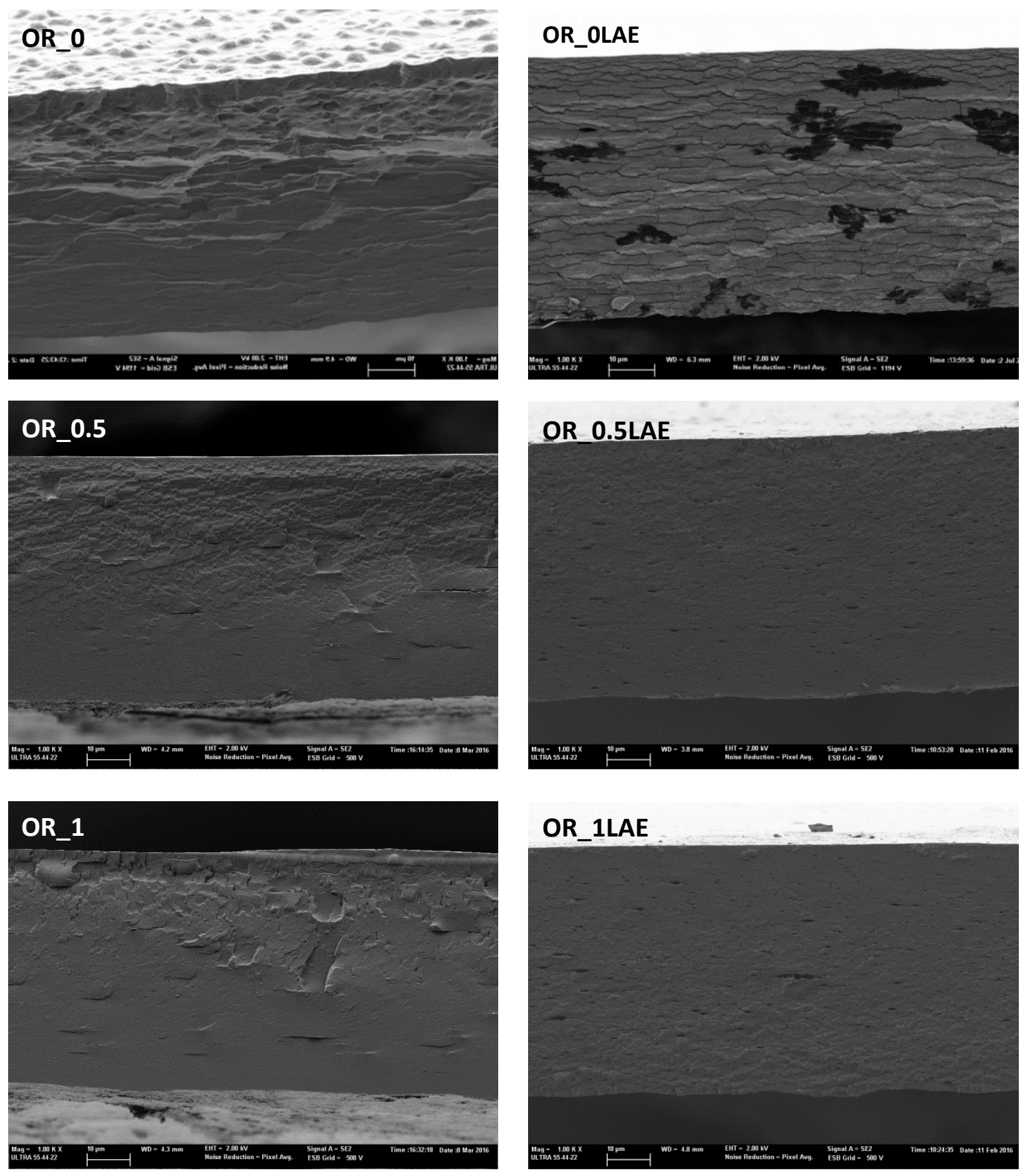

Figure 4.1 Micrographs obtained by FESEM of the cross-section of the films obtained from starch gelatin blends, with differing degrees of starch oxidation, and with or without LAE.

ATR FTIR analysis

Figure 4.2 shows the FTIR spectra of the different films, including pure starch films with differing degrees of oxidation. Non-oxidized starch-based films (DAS_0) showed characteristics peaks between 1000 and $1200 \mathrm{~cm}^{-1}$, attributed to the $\mathrm{C}-\mathrm{O}$ bond 
stretching of starch (Me et al., 2007 de Yu et al.); the peaks around 2850 and $2926 \mathrm{~cm}^{-1}$, 1450 and $1370 \mathrm{~cm}^{-1}$ are related to the $\mathrm{C}-\mathrm{H}$ stretching and bending modes of the methylene (Sheng et al., 2011); the absorption around $1640 \mathrm{~cm}^{-1}$ is a typical band residing in the spectra of starch and its derivative, related to the tightly bound water (Seligra et al., 2016; Yu et al., 2010; Zhang et al., 2012), while the peak observed around $3300 \mathrm{~cm}^{-1}$ is associated with the stretching of $\mathrm{OH}$ groups from glucose, glycerol and water (Zhang et al., 2014). As the degree of oxidation increased, the absorbance of the bands associated with $-\mathrm{OH}$ groups exhibited a lower intensity, which could be related with the reduction of the $-\mathrm{OH}$ number in the starch chains and their lower water affinity. In fact, oxidation with periodate leads to the breakage of the C-2 and C-3 bonds of the anhydroglucose units, reducing the content of hydroxyl groups and forming aldehyde groups. Nevertheless, the characteristic absorption peak around $1740 \mathrm{~cm}^{-1}$, corresponding to carbonyl $(\mathrm{C}=\mathrm{O})$ stretching vibration, presented a very weak intensity due to the formation of hemiacetal linkage between oxidised and non-oxidised starch residues (Zhang et al., 2007; Zhang et al., 2014). It is remarkable that the absorption peaks in samples with oxidised starch decreased in intensity at a constant wavenumber, as previously described by other authors (Rivero et al. (2010) for crosslinked polymer structures, probably associated with the major restrictions for bond vibration. 


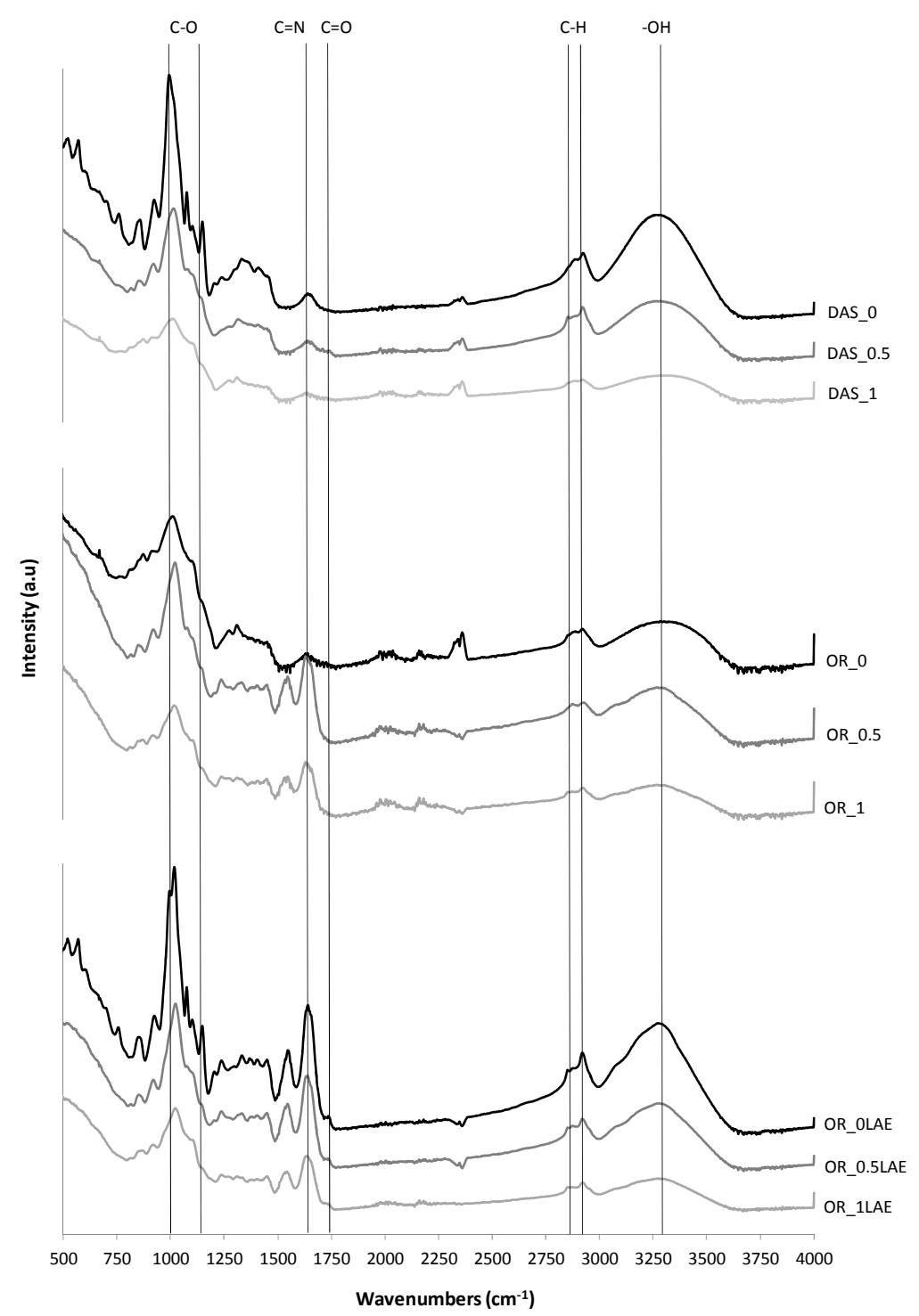

Figure 2. FTIR spectra of films obtained from starch films and starch gelatin blend films, with differing degrees of starch oxidation and with or without LAE.

Starch-gelatin blend films also exhibited a lower degree of intensity in the absorbance of the different bands, particularly those associated with the vibration of $\mathrm{OH}$ groups, which could be related with the strong interaction between both polymers forming a tight network where new bonds are formed. Particularly, dialdehyde polysaccharides are able to crosslink with amino groups of proteins through the formation of Schiff bases, imine group $(C=N)$, which is associated with a stretching vibration around $1630 \mathrm{~cm}^{-1}$ (Azeredo and Waldron, 2016; Yin et al., 2008), as observed for both formulations with oxidised starch (OR_0.5, OR_1). 
The incorporation of $\mathrm{LAE}$ introduced new $\mathrm{C}=\mathrm{O}$ and $\mathrm{NH}_{2}$ groups, with vibration bands at 1730 and $3400 \mathrm{~cm}^{-1}$, respectively (Kamoun, 2015), which is reflected in a higher relative intensity of these bands in samples containing this compound. Likewise, LAE could also promote the formation of $\mathrm{C}=\mathrm{N}$ groups, by reacting with both starch' carbonyls or gelatin amino groups, as revealed by the relative intensity of the peak at $1630 \mathrm{~cm}^{-1}$. A higher intensity of the peaks, associated with the vibration of these groups, was noticed when compared to the corresponding formulations without LAE; this could be related with a greater ability of the network to permit bond vibration and to a greater concentration of $\mathrm{C}=\mathrm{N}$ groups. Thus, the carbonyl-amino reaction to form $\mathrm{C}=\mathrm{N}$ groups was enhanced by the presence of LAE. FTIR signal attenuation was also observed in line with the degree of starch oxidation, which could be attributed to a more crosslinked structure, as previously commented on.

From FTIR analyses, the crosslinking between starch and gelatin was evidenced, as well as the participation of LAE in condensation reactions between amino groups and carbonyls. Starch oxidation greatly promotes the inter-chain bonding between polysaccharides and proteins, although the reaction probably involves, to a greater extent, molecules of low molecular weight and higher molecular mobility and reactivity, such as LAE, and short chain macromolecules resulting from the partial depolymerization of starch during oxidation, as described by Fiedorowicz and Para, (2006). Edge-chain carbonyls of non-oxidised starch can also participate in the crosslinking process. Likewise, cross-linked chains, by means of the formation of acetal bonds between carbonyls and hydroxyls, can also contribute to the polymer network formed in oxidised starch (Du et al., 2008), especially when no proteins were present (samples DAS_0.5 and DAS_1.0).

\section{Thermogravimetric analysis}

Figure 4.3 shows the thermograms obtained for the starch-gelatin films (a), with or without LAE, and for pure starch (b), with differing degrees of oxidation. The evaluation of the normalized mass loss curve with temperature for all of the formulations reflects a slight initial loss, attributed to the water retained in the polymeric network, followed by a pronounced mass loss associated with the polymer degradation. The oxidation of starch greatly affected the thermo-stability of the polymer, decreasing the temperature of both the onset and maximum degradation rates, as previously reported by other authors (Soliman et al., 1997; Zhan et al., 2012), in line with the disruption of starch chains 
(Fiedorowicz and Para, 2006). Likewise, two steps appeared in the degradation process, which can be associated with the thermal changes both in the more oxidized chains and also in those chains less affected by the oxidation process, the latter being those of high molecular weight or branched chains (such as amylopectin). In general, the thermodegradation of oxidised starch is a more prolonged process (less pronounced drop in mass) than that of non-oxidised, which suggests the involvement of different mechanisms. In fact, an initial crosslinking process could occur from about $100^{\circ} \mathrm{C}$ due to the formation of acetalic inter-chain unions through the carbonyl side groups, as reported by $\mathrm{Du}$ et al., (2008). Afterwards, the crosslinked structure degrades at higher temperature, this increasing the temperature range of the overall degradation process.

For starch-gelatin blend films, two main steps could be observed in polymer degradation. The first one, which starts near $100^{\circ} \mathrm{C}$, must be attributed to the promotion of the starchprotein reaction induced by the temperature increase. The rate of this step was greatly increased by starch oxidation and LAE addition, on the basis of the significantly lower $(p<0.05)$ onset temperature $\left(T_{0}\right)$. This phenomenon points to the prevailing reaction of the starch carbonyl groups with the protein amino groups, or to the fact that LAE is bifunctional and reacts with both carbonyl or/and amino groups in this first step. This behaviour indicates that starch-protein blend films cannot be obtained by thermoplastic processing, especially if oxidized starch is used. The reaction of non-oxidized starch and gelatin or LAE during the thermo-processing of blend films was previously reported (Moreno et al. 2016), but this was greatly enhanced in OS due to the extensive formation of carbonyl groups, which are highly reactive with protein amino groups. 

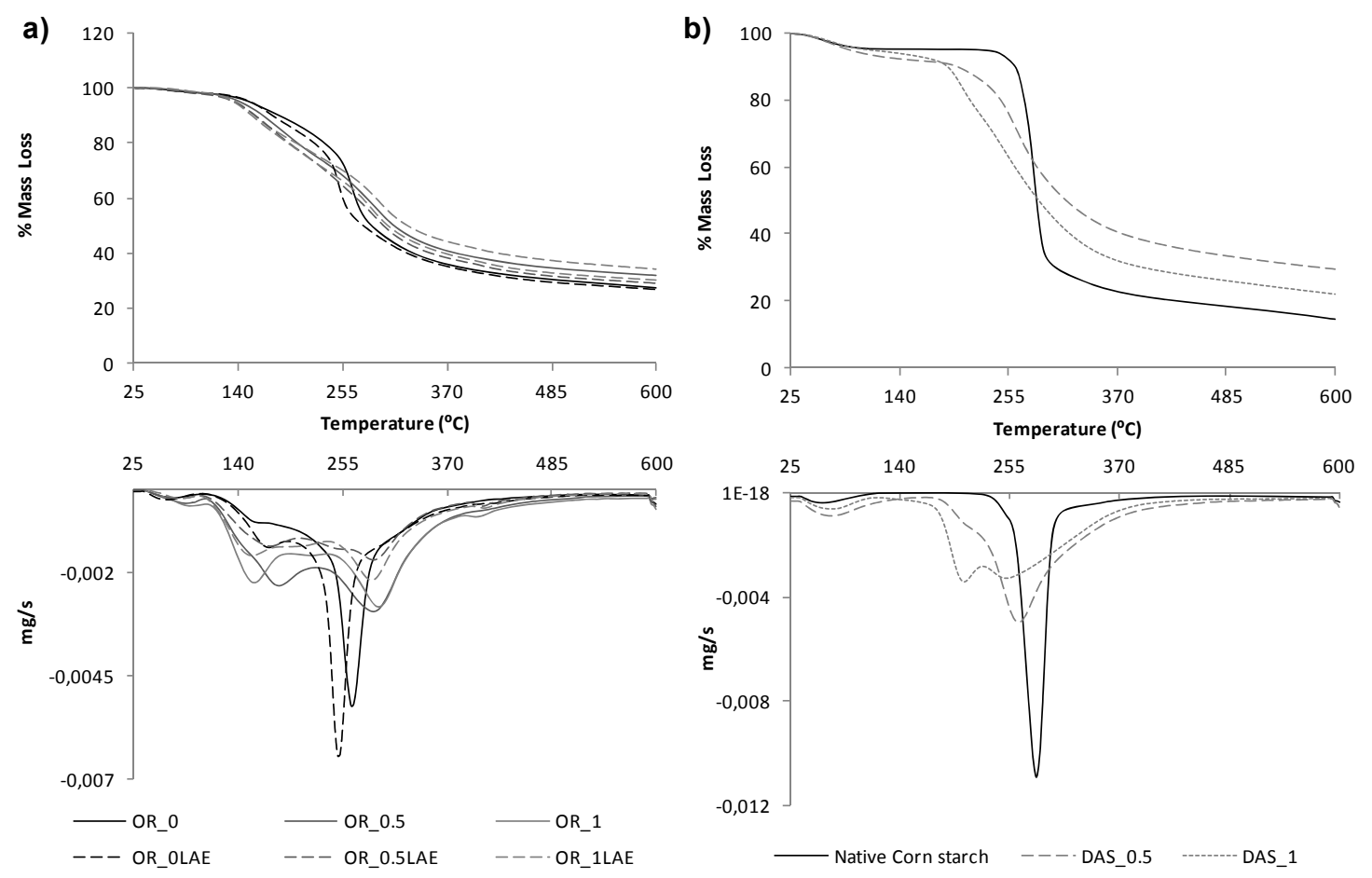

Figure 3. Thermogravimetric curves and the first derivatives of the TGA curves for film samples obtained from (a) starch-gelatin blends with differing degrees of starch oxidation, with or without LAE (b) starch with differing degrees of oxidation.

The second, and main, degradation step of the starch-gelatin films, characterized by the temperature of the fast degradation rate $\left(T_{\max }\right)$, reflected a significant increase $(p<0.05)$ in the $T_{\max }$ for films with OS, according to the previous formation of a crosslinked matrix during the first step. In this sense, it is remarkable that films containing LAE exhibited lower values of $T_{\max }$, which suggests that the participation of LAE in the crosslinking reaction did not imply the formation of such a tight network, whereas a more continuous degradation/reaction process (less marked steps) was observed for films containing this compound and oxidized starch.

Thermal analysis reveals that starch-gelatin blend films are very sensitive, when the temperature rises above $100^{\circ} \mathrm{C}$, which is greatly enhanced when the starch is oxidized, or other compounds containing amino or carbonyl groups, such as LAE, are present in the blend. These reactions promote uncontrolled crosslinking in the polymer network, which slowly degrades at higher temperatures. Therefore, the thermal processing of starch-gelatin blend films is limited by the occurrence of these uncontrolled reactions at high temperatures, also provoking the extensive formation of coloured compounds. 
On the basis of the film's microstructure and crosslinking analysis, a high level of crosslinking between oxidised starch and gelatin chains can be expected in blend films, especially for the highest ratio of starch oxidation. The addition of LAE implied its participation in the bonding reactions, given that its molecule has carbonyl and amino groups, which can compete with the macromolecules' functional groups, thus limiting the inter-chain bonds. This occurred mainly when starch was partially oxidised and there was lower carbonyl concentration in its chains.

\subsection{Tensile, barrier and optical properties of the films}

\section{Tensile properties}

The values of the tensile parameters (elastic modulus (EM, MPa), tensile strength (TS, $\mathrm{MPa}$ ) and elongation at break (\% E)), and the film thickness are shown in Table 4.1. The differing degrees of starch oxidation clearly affected the tensile behaviour of the films. The partial oxidation (OR_0.5) led to a decrease in the stiffness while increasing the stretchability of the films, in comparison with the non-oxidized formulation (OR_0). However, when the starch oxidation was complete (OR_1), films became more rigid and resistant, with lower extensibility. The crosslinking process associated with starch oxidation involved an increase in the stiffness as a consequence of the reinforcement of the matrix, but this trend was not observed for partial oxidation. The poorer progress of chain bonding, together with the possible starch de-polymerization during oxidation could yield a less cohesive polymeric network, thus exhibiting lower strength in tensile behaviour.

The effect of LAE incorporation on tensile behaviour was dependent on the degree of starch oxidation. When the oxidation was complete, LAE hardly affected the tensile behaviour of the films. However, the extensibility of partially oxidized films decreased when LAE was added, whereas it increased when LAE was added to non- oxidized films. In both cases, partial and non-oxidised films, its addition caused a decrease in stiffness and resistance to break. These different effects, depending on the degree of oxidation of starch, could be related with the different participation of this molecule in bonding reactions with carbonyl groups of starch chains or amino groups of protein, as previously commented on. At higher oxidation ratios, the carbonyls of the starch chains compete with those of LAE with the highest concentration and their reaction with the protein chains could promote inter-chain bonding. However, at intermediate oxidation ratios, 
there could be a greater contribution of LAE reactions, which are less effective at promoting the network cohesion, thus reducing the strength of the polymer matrix, but decreasing its stretchability. In fact, due to its lower molecular weight, LAE would be more reactive with carbonyl groups than gelatin and, consequently, it could be linked to the oxidized chains of starch, decreasing the degree of crosslinking of the polymer matrix. In the case of non-oxidised starch, the interfacial action of LAE between the polymer domains led to films with increased plastic deformability and lower strength, as reported by Moreno et al. (2016).

The tensile behaviour of the films indicated that the degree of crosslinking of the starchgelatin matrix, caused by the reaction between carbonyl and amino groups, did not progress to the same extent in the case of partial oxidation as a result of the heterogeneity of the chains (containing hydroxyl and carbonyl groups), which probably produces greater steric hindrances to the creation of new bonds. However, the crosslinking effect for OR_1 films was much more noticeable, as reflected by the great reinforcement of the polymer matrix. In the presence of $L A E$, the partial oxidation of starch offers more opportunities for the reaction of LAE through its carbonyl groups, which did not contribute to a reinforcement of the polymer matrix to the same extent as protein linkages. 
Table 4.1 Film thickness $(\mu \mathrm{m})$ and moisture content; Tensile parameters (Elastic modulus (EM, MPa), Tensile Strength (TS, MPa) and deformation at break (\% E)); Barrier properties (Water Vapor Permeability (WVP) and Oxygen Permeability (OP)); Colour coordinates ( $\mathrm{L}^{*}, \mathrm{C}_{a b}{ }^{*}$, $\mathrm{h}_{\mathrm{ab}}{ }^{*}$ ) and internal transmittance $\left(\mathrm{T}_{\mathrm{i}}\right)$ at $430 \mathrm{~nm}$ of the starch-gelatin blend films, with differing degrees of starch oxidation, with or without LAE, conditioned for 1 week at $53 \% \mathrm{RH}$ and $25^{\circ} \mathrm{C}$.

\begin{tabular}{|c|c|c|c|c|c|c|}
\hline & \multicolumn{2}{|c|}{ OR_0 } & \multicolumn{2}{|c|}{ OR_0.5 } & \multicolumn{2}{|c|}{ OR_1 } \\
\hline & No LAE & LAE & No LAE & LAE & No LAE & LAE \\
\hline Thickness $(\mu \mathrm{m})$ & $65 \pm 6^{b, y}$ & $61 \pm 3^{a, x}$ & $60 \pm 2^{a, x}$ & $64 \pm 2^{b, y}$ & $65 \pm 2^{b, x}$ & $65 \pm 9^{b, x}$ \\
\hline Xw(d.b. g water/g dry film) & $12,0 \pm 3,0^{b, x}$ & $10,3 \pm 0,5^{b, x}$ & $8,1 \pm 0,5^{a, x}$ & $10,6 \pm 0,5^{b, y}$ & $8,9 \pm 0,5^{a, y}$ & $7,7 \pm 1,0^{a, x}$ \\
\hline EM (MPa) & $1020 \pm 190^{b, y}$ & $510 \pm 90^{b, x}$ & $470 \pm 70^{\mathrm{a}, \mathrm{y}}$ & $360 \pm 70^{\mathrm{a}, \mathrm{x}}$ & $1290 \pm 80^{c, x}$ & $1300 \pm 200^{c, x}$ \\
\hline TS (MPa) & $33 \pm 6^{a, y}$ & $24 \pm 7^{a, x}$ & $21 \pm 6^{a, y}$ & $35 \pm 6^{a, x}$ & $46 \pm 8^{b, x}$ & $46 \pm 8^{b, x}$ \\
\hline$\% \mathrm{E}$ & $14 \pm 5^{\mathrm{b}, \mathrm{x}}$ & $35 \pm 2^{c, y}$ & $27 \pm 5^{c, y}$ & $18 \pm 10^{b, x}$ & $6,2 \pm 1,5^{a, x}$ & $7 \pm 2^{a, x}$ \\
\hline WVP $\times 10^{7}\left(\mathrm{~g} \cdot \mathrm{mm} / \mathrm{kPa} \cdot \mathrm{h} \cdot \mathrm{m}^{2}\right)$ & $6,9 \pm 0,2^{c, y}$ & $5,0 \pm 0,6^{a, x}$ & $5,0 \pm 0,3^{b, x}$ & $5,0 \pm 0,9^{a, x}$ & $4,6 \pm 0,1^{a, x}$ & $5,2 \pm 0,6^{a, y}$ \\
\hline $\mathrm{OP} \times 10^{13}\left(\mathrm{~cm}^{3} / \mathrm{m} \mathrm{s} \mathrm{Pa}\right)$ & $1,26 \pm 0,03^{b, x}$ & $2,08 \pm 0,07^{b, y}$ & $1,00 \pm 0,15^{\mathrm{ab}, \mathrm{x}}$ & $2,50 \pm 0,50^{b, x}$ & $0,75 \pm 0,09^{a, x}$ & $0,95 \pm 0,11^{\mathrm{a}, \mathrm{x}}$ \\
\hline $\mathrm{L}_{\mathrm{ab}} *$ & $80,6 \pm 0,5^{c, y}$ & $73,8 \pm 0,6^{a, x}$ & $76,8 \pm 1,1^{a, y}$ & $73,4 \pm 1,0^{a, x}$ & $78 \pm 0,8^{b, y}$ & $73,8 \pm 0,4^{b, x}$ \\
\hline $\mathrm{C}_{\mathrm{ab}} *$ & $7,27 \pm 0,17^{a, y}$ & $4,41 \pm 0,08^{a, x}$ & $28 \pm 2^{b, x}$ & $28,3 \pm 0,7^{b, x}$ & $33,3 \pm 1,0^{c, y}$ & $29,2 \pm 0,7^{c, x}$ \\
\hline$h_{a b} *$ & $98 \pm 0,3^{c, x}$ & $104 \pm 0,9^{b, y}$ & $81 \pm 2^{a, x}$ & $79,2 \pm 0,5^{a, x}$ & $91,2 \pm 0,7^{b, y}$ & $79,1 \pm 0,6^{a, x}$ \\
\hline$T_{i}(430 \mathrm{~nm})$ & $0,833 \pm 0,004^{c, y}$ & $0,826 \pm 0,005^{c, x}$ & $0,74 \pm 0,02^{b, x}$ & $0,73 \pm 0,014^{b, x}$ & $0,689 \pm 0,016^{a, x}$ & $0,711 \pm 0,004^{a, y}$ \\
\hline
\end{tabular}

Different letters $(a, b, c)$ in the same row indicate statistical differences $(p<0.05)$ between the formulations, either with or without LAE, with differing degrees of starch oxidation.

Different letters $(x, y)$ in the same row indicate statistical differences $(p<0.05)$ between samples with and without $L A E$, for each degree of starch oxidation. 
Table 4.1 shows the values of the equilibrium moisture content of the films and their barrier properties to water vapour and oxygen (WVP and OP). Starch oxidation led to a significant $(p<0.05)$ decrease in the moisture content and WVP for both degrees of oxidation, coherently with the greater hydrophobic nature of the matrix, resulting from the transformation of $-\mathrm{OH}$ into $-\mathrm{C}=\mathrm{O}$ groups in the starch chains (Zhang et al., 2007), and the crosslinking effect, which created more resistance to mass transfer in the matrix. LAE addition affected the moisture content of the films, reducing the value for non-oxidised and fully oxidised starch, but increasing the value at intermediate oxidation ratio. This also points to differences in the network crosslinking when LAE is present, which affects the active points for water adsorption, depending on the degree of oxidation. Oxygen permeability was also significantly reduced $(p<0.05)$ by starch oxidation, which can also be related to the tighter matrix caused by crosslinking and the milder water plasticising effect associated with the lower water content. Only films containing LAE with an intermediate oxidation ratio exhibited non-reduced oxygen permeability, which is coherent with the poorer progress of the inter-chain bonds due to the LAE competence in the carbonyl-amino reactions, previously commented on. Thus, starch oxidation allows less polar and tighter polymer matrices to be obtained, with lower water affinity and enhanced barrier properties, thus improving both water vapour and oxygen permeability. This is explained by the weaker water plasticizing effect, since the films' moisture content falls, and also by the crosslinking in the polymer network, which slows down the transport mechanisms by promoting the tortuosity factor of the polymeric network.

\section{Optical properties}

Table 4.1 shows the values of the colour coordinates $\left(L_{a b}{ }^{*}\right.$, lightness; $C_{a b}{ }^{*}$, chrome; $h_{a b}{ }^{*}$, hue) of the different films. Starch oxidation significantly reduced $(p<0.05)$ the lightness and hue of films and gave rise to a significant $(p<0.05)$ increase in the chrome; this is coherent with the formation of brown compounds resulting from the carbonyl-amino reactions to form Maillard compounds. Specifically, the yellow-brown coloration associated with protein-aldehyde reactions may be attributed to the formation of conjugated Schiff's bases, which are intermediate products of the Maillard reaction (Cheftel et al., 1985; Martucci and Ruseckaite,, 2009). In addition, when the LAE was incorporated, all of the oxidized formulations exhibited a decrease in lightness and hue, obtaining browner films, which is coherent with the involvement of LAE in the browning 
reactions, due to the presence of amino and carbonyl groups in its molecular structure. Both the oxidized formulations containing LAE and the film with an intermediate degree of oxidation without LAE had very similar colour coordinate values, whereas films with fully oxidized starch without LAE were slightly lighter and less red, thus indicating that browning progressed to a lesser extent in this case, where a more effective polymer crosslinking was observed. On the other hand, the incorporation of LAE into films with non-oxidised starch provoked a decrease in the films' lightness and colour saturation, while also promoting the film yellowish, which also points to the formation of coloured compounds to a certain extent.

The internal transmittance $\left(T_{i}\right)$ of the films also decreased in line with starch oxidation, mainly at lower wavelengths, where brown compounds absorb light Table 1 also shows the values of $T_{i}$ at $430 \mathrm{~nm}$, which reflect that the higher the degree of starch oxidation, the lower the $T_{i}$ values. This behaviour was coherent with the selective absorption of brown products (Maillard compounds) mainly coming from the reaction of low molecular weight compounds, such as the reducing sugars resulting from the partial hydrolysis of starch. Condensation reactions were encouraged by the greater availability of carbonyl groups obtained during the oxidation process. The addition of LAE did not imply any significant changes in the transmittance of the films, except for OD_1 films, for which its addition led to an increase in internal transmittance. Crosslinking in the matrix can also contribute to a reduction in internal transmittance due to the promotion of the film's opacity (Martucci and Ruseckaite, 2009).

\subsection{Water solubility, water uptake capacity and overall migration of the films.}

To analyse the effect that the crosslinking promoted by starch oxidation has on the films' hydrophobicity, their water solubility, water uptake capacity and overall migration in different food simulants were analysed.

Figure 4.4 shows the water solubility values of the films, expressed as weight loss $\%$ $(\mathrm{WL} \%)$ in water, and the water uptake capacity ( $\Delta \mathrm{W} \%)$ expressed as the mass of water gained by the dry film. Starch oxidation led to a highly significant decrease $(p<0.05)$ in the water uptake capacity of the films, coherently with the polarity reduction in the polymeric matrix, in line with the fall in the number of $-\mathrm{OH}$ groups, and by the crosslinking of the polymer chains which restrict the water absorption by steric 
hindrance. Nonetheless, the solubility in water (WL \%) of the films was significantly greater $(p<0.05)$ in the case of oxidized samples. The periodate oxidation of starch led to the formation of dialdehyde starch, but also induced a disruption of the starch polysaccharide chains. This fragmentation could result in both changes in the organization of starch chains and solubility (Fiedorowicz and Para, 2006).

WL \%

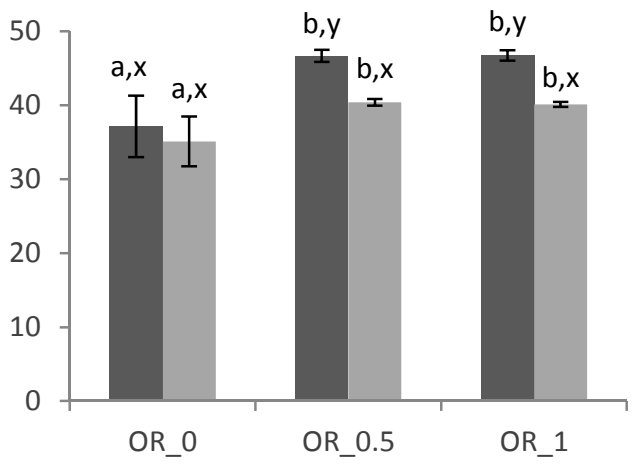

$\Delta \mathbf{W} \%$

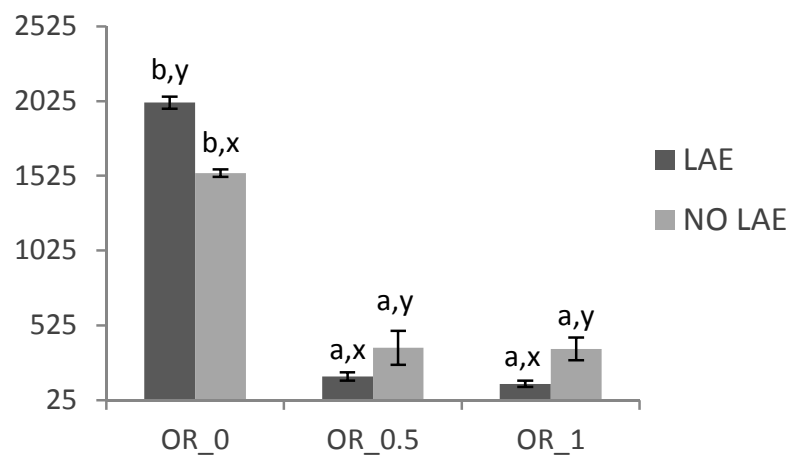

Figure 4.4 Weight loss (WL\%, g per100 g dried film) and Water uptake ( $\Delta \mathrm{W} \%, \mathrm{~g}$ water per $100 \mathrm{~g}$ dried film) of the films after $24 \mathrm{~h}$ of immersion in distilled water at $25^{\circ} \mathrm{C}$. Mean values and standard deviation. Different letters $(a, b)$ indicate significant differences $(p<0.05)$ between samples with the differing degrees of starch oxidation. Different letters $(x, y)$ indicate significant differences $(p<0.05)$ between samples, with and without LAE.

On the other hand, the addition of LAE involved a significant increase $(p<0.05)$ in solubility, while significantly reducing the water uptake values for both oxidized formulations, contrary to what occurred for non-oxidized films. The higher solubility values of oxidized films with LAE could be explained by its tighter attachment to the carbonyl groups present in the low molecular weight molecules resulting from the partial hydrolysis of starch, which were easily released into the water. Likewise, the reduction in the water uptake capacity produced by LAE is coherent with the involvement of this molecule in the crosslinking of the polymers, thus cooperating in the steric limitation of water absorption in the network.

Table 4.2 summarizes the mean values of the overall migration of the films into food stimulants with differing polarity: simulant $A$ (ethanol $10 \% \mathrm{v} / \mathrm{v}$, simulating food of hydrophilic nature), simulant $B$ (acetic acid $3 \% \mathrm{w} / \mathrm{v}$, simulating food of hydrophilic nature 
and $\mathrm{pH}$ below 4.5) and simulant $\mathrm{D} 2$ (isooctane, simulating food of lipophilic nature and with free surface fats). All of the film formulations exceeded the threshold level of 10 $\mathrm{mg} / \mathrm{dm}^{2}$ established by the current law (Commission Regulation (EU) No 10/2011) for every simulant, the highest values being obtained in the acid medium. However, the oxidized formulation in $3 \%$ acetic acid had significantly $(p<0.05)$ lower migration values than non-oxidized formulations. This suggests that crosslinking was effective at reducing the disintegration action of the acid medium, thus limiting the release of film compounds. On the contrary, the oxidized films showed a significantly $(p<0.05)$ higher degree of migration in ethanol $10 \%(\mathrm{v} / \mathrm{v})$ than the non-oxidised. This could be attributed to the formation of low molecular compounds during the oxidation process, which is more easily released into the aqueous media. No significant differences were noticed for the different films' migration in isooctane. The addition of LAE only affected the migration values in the films with non-oxidised starch, promoting their release in aqueous media at neutral and acid $\mathrm{pH}$, only. This agrees with the partial attachment of LAE to the polymer network in oxidised matrices, as previously commented on, thus restricting its migration observed in non-oxidised matrices.

Table 2. Overall migration values $\left(\mathrm{mg} \mathrm{dm}^{-2}\right)$ of the different films into different food simulants (Ethanol (10\% v/v), Simulant A; Acetic Acid (3\% w/v), Simulant B; lisooctane, Simulant D2). Sample codes refer to the degree of oxidation of the corn starch. Mean values and standard deviation.

\begin{tabular}{lccc}
\hline & Etanol 10 \% (v/v) & Acetic Acid 3 \% (w/v) & Isooctane \\
\hline OR_0 & $108 \pm 15^{\mathrm{a}, \mathrm{y}}$ & $362 \pm 36^{\mathrm{a}, \mathrm{z}}$ & $47 \pm 24^{\mathrm{a}, \mathrm{x}}$ \\
\hline OR_0LAE & $348 \pm 52^{\mathrm{c}, \mathrm{y}}$ & $622 \pm 148^{\mathrm{b}, \mathrm{z}}$ & $126 \pm 99^{\mathrm{a}, \mathrm{x}}$ \\
\hline OR_0.5 & $243 \pm 30^{\mathrm{b}, \mathrm{y}}$ & $236 \pm 21^{\mathrm{a}, \mathrm{y}}$ & $51 \pm 65^{\mathrm{a}, \mathrm{x}}$ \\
\hline OR_0.5LAE & $260 \pm 18^{\mathrm{b}, \mathrm{y}}$ & $277 \pm 16^{\mathrm{a}, \mathrm{y}}$ & $29 \pm 5^{\mathrm{a}, \mathrm{x}}$ \\
\hline OR_1 & $218 \pm 40^{\mathrm{b}, \mathrm{y}}$ & $247 \pm 20^{\mathrm{a}, \mathrm{y}}$ & $25 \pm 32^{\mathrm{a}, \mathrm{x}}$ \\
\hline OR_1LAE & $237 \pm 3^{\mathrm{b}, \mathrm{y}}$ & $280 \pm 8^{\mathrm{a}, \mathrm{z}}$ & $30,1 \pm 0,5^{\mathrm{a}, \mathrm{x}}$ \\
\hline
\end{tabular}

Different letters $(a, b, c)$ in the same column indicate statistical differences $(p<0.05)$ between the formulations for the same simulant.

Different letters $(x, y, z)$ indicate statistical differences $(p<0.05)$ between simulants for each formulation.

Starch oxidation and the subsequent crosslinking to gelatin greatly limit the water uptake capacity of the films, although they did not reduce either the film's water solubility or the migration values into neutral aqueous food simulants. Nevertheless, crosslinked films 
were more resistant to the acid systems, coherent with the formation of a tight network. The partial disruption of starch chains by oxidation led to an increase in the soluble fraction of the films. In the same sense, the addition of a low molecular weight compound (LAE) promoted the film's solubility in water and its migration into aqueous food simulants.

\subsection{Effect of starch oxidation on the stability of the film properties.}

For the purposes of evaluating the potential progress of both Maillard and crosslinking reactions in the film network throughout time, the colour parameters, tensile properties and water vapour barrier capacity of the films were analysed after 5 storage weeks at $53 \% \mathrm{RH}$ and $25^{\circ} \mathrm{C}$.

Figure 4.5 compares the values of the tensile properties of the films (EM, TS and \% E) and WVP obtained after 1 and 5 weeks of storage. The results obtained pointed to a progression of the crosslinking process throughout storage time in oxidised formulations, since the two films with oxidised starch, both the one with and the one without LAE, exhibited a remarkable increase $(p<0.05)$ in $E M$ and a decrease in the film extensibility. Likewise, a slight increase in WVP was observed for these samples when there was no $\mathrm{LAE}$ in the formulation.

On the other hand, the colour of the films also changed during storage. Figure 4.6 shows the locust of the different films in the $a^{*} b^{*}$ chromatic diagram after 1 and 5 weeks of storage; here, although no notable changes can be appreciated for the films with nonoxidised starch, either with or without LAE, those films containing oxidized starch evolved towards a redder hue with higher colour saturation. These chromatic changes were associated with a $16 \%$ reduction in lightness for the films with an intermediate degree of starch oxidation, both with and without LAE, a $9 \%$ reduction for the LAE-free sample with fully oxidised starch and a $10 \%$ increase in the case of non-oxidized starch with LAE. These colour changes also indicate the progression of the formation of conjugated Schiff's bases (intermediate products of the Maillard reaction) causing an increase in colour intensity (Martucci and Ruseckaite, 2009) throughout storage. Browning reactions progressed to a greater extent in the films with oxidized starch, thus indicating the progressive reaction between carbonyls and amino groups. The films with an intermediate oxidation ratio exhibited the greatest changes, both with and without $\mathrm{LAE}$, whereas in the case of those with the highest oxidation ratio, the browning of the 
films with LAE was more limited. However, the colour of the LAE-free films with the highest oxidation degree, which exhibited less initial browning, changed until they reached similar browning levels to the OR_1LAE sample.
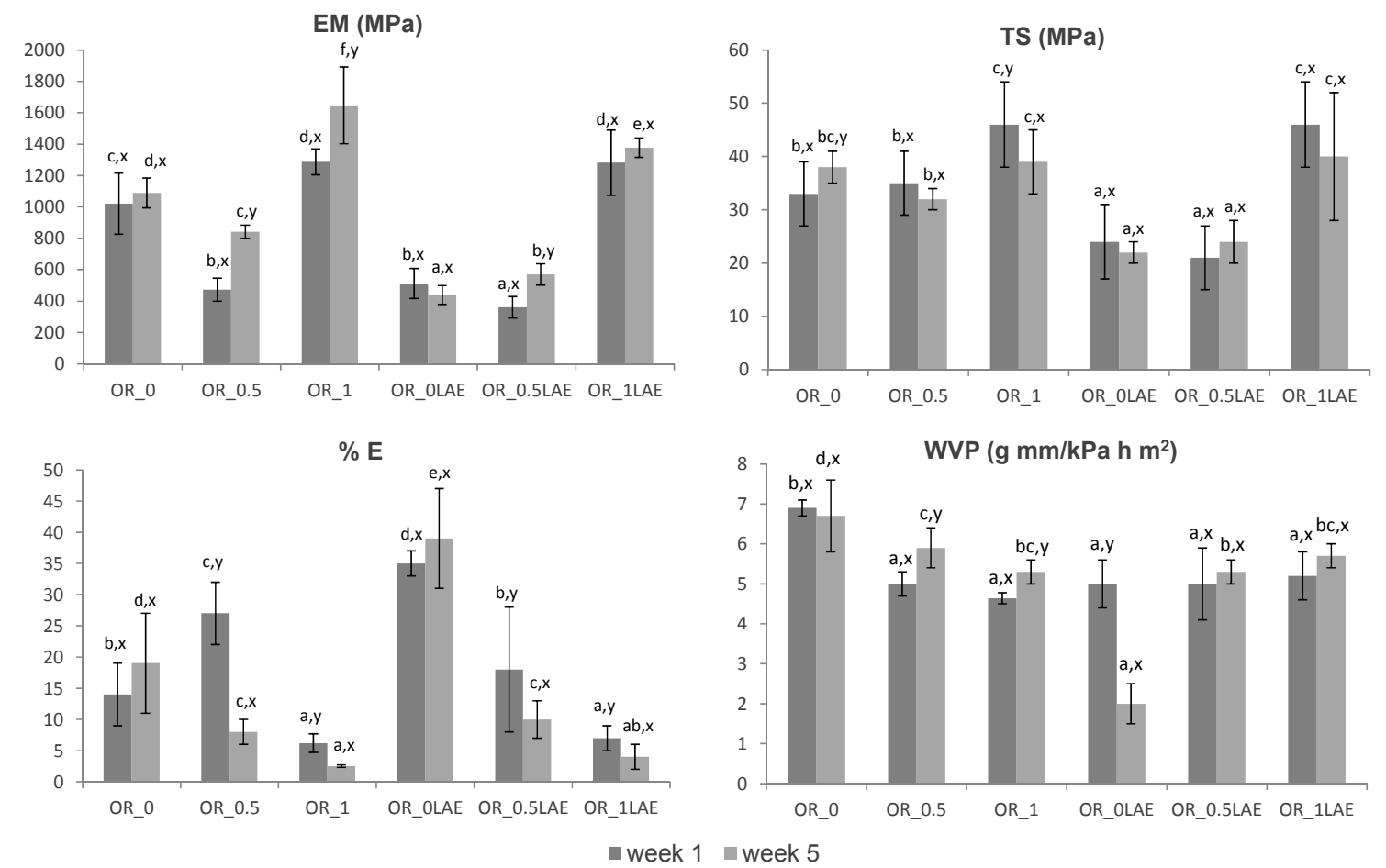

Figure 5. Effect of storage time (1 and 5 weeks) on the tensile parameters (EM, TS and $\%$ E) and Water Vapour Permeability (WVP) of the starch-gelatin blend films, with differing degrees of starch oxidation, with or without LAE films, conditioned at $53 \% \mathrm{RH}$. Mean values and standard deviation. Different letters (a, b, c, d, e, f) indicate significant differences $(p<0.05)$ between the different film formulations for the same conditioning time. Different letters $(x, y)$ indicate significant differences $(p<0.05)$ between both conditioning times for the same formulation.

The browning reactions progressed in oxidized starch films, mainly in those with an intermediate oxidation degree, giving rise to more coloured films, which can limit their application. Nevertheless, these Maillard compounds have antimicrobial activity (Hauser et al., 2014; Wu et al., 2014), which could improve the films' functionality, imparting active properties. In fact, in vitro studies with LAE-free oxidized films also exhibited antilisterial activity (results not shown), without any additional incorporation of active compounds. 


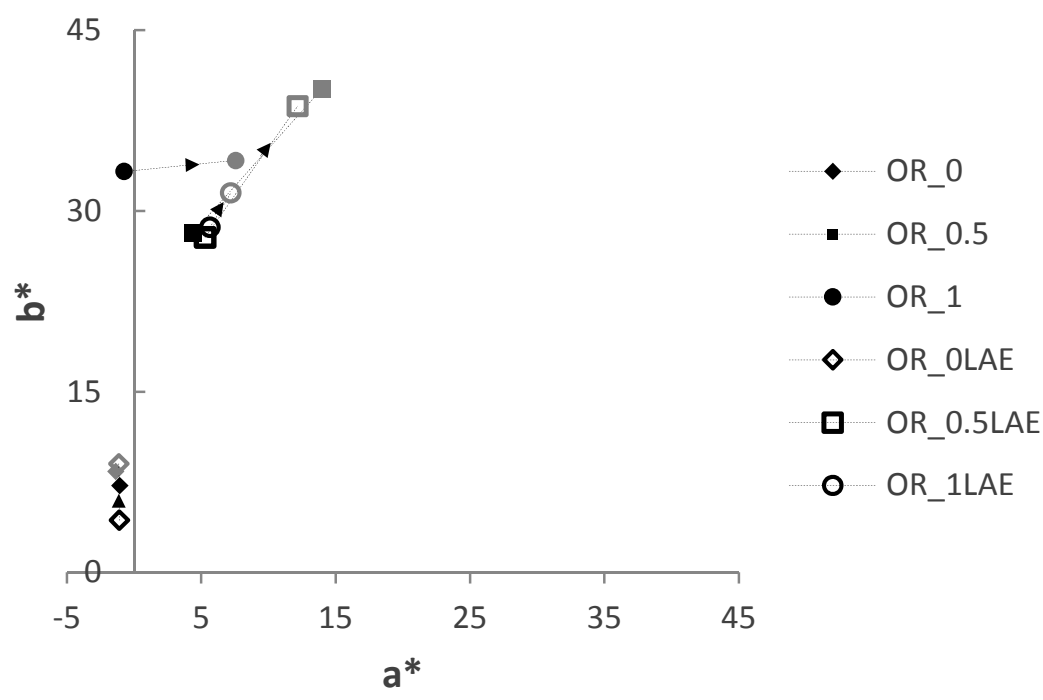

Figure 6. Colour development in the $a^{*} b^{*}$ chromatic diagram of the starch-gelatin films conditioned at $53 \% \mathrm{RH}$ and $25^{\circ} \mathrm{C}$. ( 1 week: black marks, and 5 weeks: grey marks). 


\section{CONCLUSIONS}

tarch oxidation with sodium periodate greatly promoted crosslinking in starchgelatin (1:1) films, enhancing the films' strength and oxygen and water vapour barrier capacity, while reducing their water uptake capacity and migration to acid media. A glucose:periodate molar ratio of $1: 1$ was more effective than 1:0.5, due to the greater progress of di-aldehyde formation, which offers more reactive groups for the amino-carbonyl reaction and the formation of inter-chain bonds between polysaccharides and proteins. Incorporating $\mathrm{LAE}$ as an antimicrobial compound interferes with the polymer crosslinking reactions due to its bifunctional nature: it contains carbonyl and amino groups which also react with the polymer chains, especially when there is an intermediate degree of starch oxidation. This affected the tensile behaviour of the films, which were less stiff and stretchable. Nevertheless, an amino-carbonyl condensation reaction also provoked browning in the films, in line with the formation of Maillard compounds. This browning, as well as crosslinking, progressed in the film network throughout storage, especially in partially oxidized starch films, which could compromise their application for certain uses. Nevertheless, the Maillard compounds formed could confer active properties on the films due to their antimicrobial capacity.

\section{Acknowledgements}

The authors acknowledge the financial support provided by Ministerio de Economía y Competividad (Projects AGL2013-42989-R and AGL2016-76699-R). The authors also thank Oscar Gil and Amparo Ribes from the Institute of Materials Technology (UPV) for the support and assistance in the use of the infrared spectrometer and the services rendered by the Electron Microscopy Service of the UPV. Olga Moreno Marro also thanks the Ministerio de Educación, Cultura y Deporte for the FPU 2012-1121 grant. 


\section{REFERENCES}

Acosta, S., Jiménez, A., Cháfer, M., González-Martínez, C., \& Chiralt, A. (2015). Physical properties and stability of starch-gelatin based films as affected by the addition of esters of fatty acids. Food Hydrocolloids, 49, 135-143.

ASTM. (1995). Standard test methods for water vapour transmission of materials. In Standard designations: E96-95 annual book of ASTM standards. Philadelphia, PA: American Society for Testing and Materials.

ASTM. (2001). Standard test method for tensile properties of thin plastic sheeting. In Standard D882 annual book of American Standard Testing Methods. Philadelphia, PA: American Society for Testing and Materials. ASTM.

ASTM. (2005). Standard test method for oxygen gas transmission rate through plasticfilm and sheeting using a coulometric sensor. In Standard designation: D3985-05:annual book of American Society for Testing Materials. West Conshohocken, PA: ASTM.

Atarés, L., Bonilla, J., \& Chiralt, A. (2010). Characterization of sodium caseinate-based edible films incorporated with cinnamon or ginger essential oils. Journal of Food Engineering, 100(4), 678-687.

Azeredo, H. M., \& Waldron, K. W. (2016). Crosslinking in polysaccharide and protein films and coatings for food contact-A review. Trends in Food Science \& Technology, 52, 109-122.Bakal, G., \& Diaz, A. (2005). The lowdown on lauric arginate. Food Quallity, 12(1), 54-61.

Balaguer, M. P., Gómez-Estaca, J., Gavara, R., \& Hernandez-Munoz, P. (2011). Biochemical properties of bioplastics made from wheat gliadins cross-linked with cinnamaldehyde. Journal of agricultural and food chemistry, 59(24), 13212-13220.

Barnett, I., (2011). Packaging Solutions Throughout the Supply Chain: Technology, Trends and Future Outlook. Business Insight, London.

Byun, Y., \& Kim, Y. T. (2014). Chapter 14 - Bioplastics for food packaging: Chemistry and physics. In J. H. Han (Ed.), Innovations in food packaging (2nd ed., pp. 353-368). San Diego: Academic Press.

Cazón, P., Velazquez, G., Ramírez, J. A., \& Vázquez, M. (2016). Polysaccharide-based films and coatings for food packaging: A review. Food Hydrocolloids.

Cheftel, J.C., Cuq, J.-L., Lorient, D., 1985. Amino acids, peptides, and proteins. In: Fennema, O.R. (Ed.), Food Chemistry. Marcel Dekker, New York, pp. 245-369.

Commission Regulation (EU) No. 10/2011 of 14 January 2011 on plastic materials and articles intended to come into contact with food.

Du, Y. L., Cao, Y., Lu, F., Li, F., Cao, Y., Wang, X. L., \& Wang, Y. Z. (2008). Biodegradation behaviors of thermoplastic starch (TPS) and thermoplastic dialdehyde starch (TPDAS) under controlled composting conditions. Polymer Testing, 27(8), 924-930. 
Fakhoury, F. M., Martelli, S. M., Bertan, L. C., Yamashita, F., Mei, L. H. I., \& Queiroz, F. P. C. (2012). Edible films made from blends of manioc starch and gelatin-Influence of different types of plasticizer and different levels of macromolecules on their properties. LWT-Food Science and Technology, 49(1), 149-154.

Fiedorowicz, M., \& Para, A. (2006). Structural and molecular properties of dialdehyde starch. Carbohydrate Polymers, 63(3), 360-366.

Hauser C., Müller U., Sauer T., Augner K., Pischetsrieder. (2014). Maillard reaction products as antimicrobial components for packaging films. Food chemistry, 145, 603-613.

Hawkins, D.R., Rocabayera, X., Ruckman, S., Segret, R., Shaw, D. (2009). Metabolism and pharmacokinetics of ethyl Na-lauroyl-L-arginate hydrochloride in human volunteers. Food and Chemical Toxicology, 47, 2711-2715.

Higueras, L., López-Carballo, G., Hernández-Muñoz, P., Gavara, R., \& Rollini, M. (2013). Development of a novel antimicrobial film based on chitosan with LAE (ethyl-N a-dodecanoyl-Larginate) and its application to fresh chicken. International journal of food microbiology, 165(3), 339-345.

Hutchings, J. B. (1999). Food and colour appearance (2nd ed.). Gaithersburg, MD: Chapman and Hall/Food Science Book/Aspen Publication.

Jiménez, A., Fabra, M. J., Talens, P., \& Chiralt, A. (2012). Edible and biodegradable starch films: a review. Food and Bioprocess Technology, 5(6), 2058-2076.

Kamoun, E. A. (2016). N-succinyl chitosan-dialdehyde starch hybrid hydrogels for biomedical applications. Journal of advanced research, 7(1), 69-77.

Martucci, J. F., \& Ruseckaite, R. A. (2009). Tensile properties, barrier properties, and biodegradation in soil of compression-Molded gelatin-dialdehyde starch films. Journal of Applied Polymer Science, 112(4), 2166-2178.

McHugh, T. H., Avena-Bustillos, R., \& Krochta, J. M. (1993). Hydrophobic edible films: modified procedure for water vapor permeability and explanation of thickness effects. Journal of Food Science, 58(4), 899-903.

Moreno, O., Pastor, C., Muller, J., Atarés, L., González, C., \& Chiralt, A. (2014). Physical and bioactive properties of corn starch-Buttermilk edible films.Journal of Food Engineering, 141, 2736.

Moreno, O., Atarés, L., \& Chiralt, A. (2015). Effect of the incorporation of antimicrobial / antioxidant proteins on the properties of potato starch films. Carbohydrate polymers, 133, 353364.

Moreno, O., Díaz, R., Atarés, L., \& Chiralt, A. (2016). Influence of the processing method and antimicrobial agents on properties of starch-gelatin biodegradable films. Polymer International.

Muriel-Galet, V., López-Carballo, G., Hernández-Muñoz, P., \& Gavara, R. (2014). Characterization of ethylene-vinyl alcohol copolymer containing lauril arginate (LAE) as material for active antimicrobial food packaging. Food packaging and shelf life, 1(1), 10-18.

Ortega-Toro, R., Jiménez, A., Talens, P., \& Chiralt, A. (2014). Properties of starch-hydroxypropyl methylcellulose based films obtained by compression molding. Carbohydrate polymers, 109, 155165. 
Rhim, J. W., Gennadios, A., Weller, C. L., Cezeirat, C., \& Hanna, M. A. (1998). Soy protein isolate-dialdehyde starch films. Industrial Crops and Products, 8(3), 195-203.

Rivero, S., García, M. A., \& Pinotti, A. (2010). Crosslinking capacity of tannic acid in plasticized chitosan films. Carbohydrate Polymers, 82(2), 270-276.

Rodríguez, E., Seguer, J., Rocabayera, X., Manresa., A. (2004) Cellular effects of monohydrochloride of L-arginine, Na-lauroyl ethylester (LAE) on exposure to Salmonella typhimurium and Staphylococcus aureus. Journal of Applied Microbiology. 96, 903-912.

Seligra, P. G., Jaramillo, C. M., Famá, L., \& Goyanes, S. (2016). Biodegradable and nonretrogradable eco-films based on starch-glycerol with citric acid as crosslinking agent. Carbohydrate polymers, 138, 66-74.

Sheng, Y., Wang, Q. H., Xu, X. C., Jiang, W. Y., Gan, S. C., \& Zou, H. F. (2011). Oxidation of cornstarch using oxygen as oxidant without catalyst. LWT - Food Science and Technology, 44, 139-144.

Soliman, A. A., El-Shinnawy, N. A., \& Mobarak, F. (1997). Thermal behaviour of starch and oxidized starch. Thermochimica Acta, 296(1), 149-153.

Tharanathan, R. N. (2003). Biodegradable films and composite coatings: past, present and future. Trends in Food Science \& Technology, 14(3), 71-78.

Wang, X., Gu, Z., Qin, H., Li, L., Yang, X., \& Yu, X. (2015). Crosslinking effect of dialdehyde starch (DAS) on decellularized porcine aortas for tissue engineering. International journal of biological macromolecules, 79, 813-821.

Wu Shuping., Hu Jiao., Wei Liuting., Du Y., Shi X., Zhang L. (2014). Antioxidant and antimicrobial activity of Maillard reaction products fron xylan with chitosan/chitooligomer/glucosamine hydrochloride/taurine model systems. Food Chemistry 143, 148-203

Yin, Q. F., Ju, B. Z., Zhang, S. F., Wang, X. B., \& Yang, J. Z. (2008). Preparation and characteristics of novel dialdehyde aminothiazole starch and its adsorption properties for $\mathrm{Cu}$ (II) ions from aqueous solution. Carbohydrate Polymers, 72(2), 326-333.

Yu, J., Chang, P. R., \& Ma, X. (2010). The preparation and properties of dialdehyde starch and thermoplastic dialdehyde starch. Carbohydrate Polymers, 79(2), 296-300.

Zhang, L., Zhang, S., Dong, F., Cai, W., Shan, J., Zhang, X., \& Man, S. (2014). Antioxidant activity and in vitro digestibility of dialdehyde starches as influenced by their physical and structural properties. Food chemistry, 149, 296-301.

Zhang, S. D., Zhang, Y. R., Zhu, J., Wang, X. L., Yang, K. K., \& Wang, Y. Z. (2007). Modified corn starches with improved comprehensive properties for preparing thermoplastics. Starch-Stärke, 59(6), 258-268.

Zhang, Y. R., Wang, X. L., Zhao, G. M., \& Wang, Y. Z. (2012). Preparation and properties of oxidized starch with high degree of oxidation. Carbohydrate Polymers, 87(4), 2554-2562. 


\section{CHAPTER 5}

\section{APPLICATION OF THE ACTIVE FILMS CONTAINING LAE ON REAL FOODS: MARINATED SALMON AND CHICKEN BREAST FILLETS.}

Active starch-gelatin films for shelf-life extension of marinated salmon

Starch-gelatin antimicrobial packaging materials to extend the shelf life of chicken breast fillets 


\section{ACTIVE STARCH-GELATIN FILMS FOR SHELF-LIFE EXTENSION OF MARINATED SALMON}

\section{Olga Moreno*, Àgueda Gil, Lorena Atarés, Amparo Chiralt.}

Departamento de Tecnología de Alimentos - Instituto de Ingeniería de Alimentos para el Desarrollo. Universitat Politècnica de València, Camino de Vera s/n 46022 Valencia, Spain 


\section{ABSTRACT}

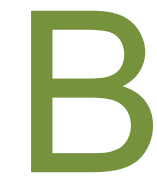

iodegradable active films were obtained by casting, by blending glycerol plasticized oxidized corn starch (OS) and bovine gelatine (BG) (1:1 mass ratio), with and without ethyl lauroyl arginate (LAE) as antimicrobial agent $(1.3 \mathrm{~g}$ $\mathrm{LAE} / 100 \mathrm{~g}$ polymer). Water vapour barrier capacity and colour of the films conditioned at 53 or $88 \%$ relative humidity were determined. The incorporation of LAE did not notably affect film properties in terms of water adsorption capacity and water vapour permeability, which were not enough reduced. This resulted in weight losses of marinated salmon samples packaged in these films. Both LAE incorporation and high RH promoted film browning, coherently with the progression of Maillard reactions between amino groups of gelatine or LAE and carbonyl groups of oxidized starch. These compounds imparted antimicrobial properties to the films with and without LAE, both exhibiting antilisterial activity in in vitro tests. The antimicrobial efficacy of both film formulations was confirmed by the great reduction of total viable counts in stored salmon samples, remaining below the legal limit after 45 storage days.

KEYWORDS: biodegradable films, corn starch, bovine gelatine, LAE, marinated salmon. 


\section{INTRODUCTION}

Nowadays, quality and safety preservation in food is a serious concern for process operations, since during their manipulation and transport, foodstuffs, mainly fresh or minimally processed, are susceptible to spoilage microorganisms (Tharanthan et al, 2003). The use of suitable active packaging protects food products against chemical contaminants, oxygen, moisture, mechanical damage, and deterioration caused by spoilage microorganisms, from packaging to its delivery to the consumer (Rhim et al., 2013; Sung et al., 2013). Petroleum-derived synthetic plastics have been commonly used for food packaging due to their low cost and their optimum processing and physical properties (Siracusa et al., 2008), but their serious environmental impact (SánchezGarcía et al., 2008) has driven current research towards biobased/biodegradable food packaging materials (Byun \& Kim, 2014; Cazón et al., 2016).

Along these lines, starch is one of the most promising materials due to its ready availability, low cost and food compatibility and is the subject of extensive research (Moreno et al., 2015, Cazón et al., 2016). Nonetheless, thermoplastic starch films have some drawbacks, namely their poor mechanical properties and those associated with their highly hydrophilic nature, such as poor water barrier capacity and low water resistance (Du et al., 2008; Ortega-Toro et al., 2014). These drawbacks can be addressed by blending it with other renewable polymers, such as gelatin, which has been reported to enhance the tensile properties of starch films (Acosta et al., 2015; Fackhoury et al., 2013). In addition, chemical modification of starch, such as oxidation (Masina et al., 2016), can increase its hydrophobic nature, since the oxidative cleavage of the C-2 and C-3 bond of the anhydroglucose units gives rise to di-aldehyde starch (DAS), thus reducing the number of hydroxyl groups and so its hydrophilic nature (Yu et al., 2010, Du et al., 2008). Likewise, the condensation reaction between carbonyl and amino groups from proteins enables DAS to act as a crosslinking agent (Azeredo and Waldron, 2016; Wang et al., 2015), although it can lead to film browning as a result of the formation of Maillard compounds (Moreno et al., 2016).

Films based on DAS/Protein blends have been reported to show better functionality (Martucci et al., 2009; Rhim et al., 1998), and they are suitable matrices for the incorporation of antimicrobial compounds (Acosta et al., 2016; Pizzoli et al., 2016), since 
they can exert a controlled release of the active compounds to the food surface. The inclusion of antimicrobial agents in polymer matrices to develop antimicrobial packaging is a promising strategy with which (Salarbashi et al., 2016) to fight both spoilage microorganisms, mainly responsible for off-odours, off-flavours, texture problems or food discoloration and also pathogenic microorganisms that can affect human health (Davidson and Taylor, 2007). In this sense, Starch/Gelatin blend films incorporated with ethyl lauroyl arginate ( $\mathrm{N}$ - $\alpha$-lauroyl-l-arginine ethyl ester monohydrochloride, LAE) have been proven to exhibit antilisterial activity in in vitro tests (Moreno et al., 2016). More specifically, LAE is a promising antimicrobial compound considered as GRAS (Generally recognized as safe) by the FDA with a maximum dose of up to 200 ppm (Kang et al., 2014), and accepted as food additive (E243, in Europe) for several food products, (Hawkins et al., 2009; Higueras et al., 2013). It is a potent antimicrobial agent, derived from lauric acid, L-arginine, and ethanol, with a wide spectrum of antimicrobial activity (Muriel-Galet et al., 2014), reported to cause cell growth inhibition or death by increasing the permeability of the cell membrane, as a consequence of the membrane protein denaturation (Rodriguez et al., 2004).

Fish and seafood products are highly perishable mainly due to microbial spoilage, (Aubourg et al., 2007) which make them good candidates for preservation by using antimicrobial packaging. Therefore, they are highly susceptible to Listeria spp. contaminations (ILSI Research Foundation / Institute of Risk Sciences, 2005, USFDA, 2003), which implies a huge problem for food safety, mainly due to the high mortality rate associated with listeriosis (Scallan et al., 2011). Refrigeration conditions are insufficient to inhibit the growth of Listeria spp (Cornu et al., 2006; Eklund et al., 1995) and it is essential to develop and implement strategies with which to reduce the initial levels of contamination, as well as to prevent the growth of these bacteria in fish products. In this sense, active packaging based on LAE may be a good means of facing up to this issue, since LAE has been successfully proven to be effective at controlling the growth of Listeria moncytogenes in different food matrices, such as roasted turkey (Jiang et al., 2011), frankfurters (Martín et al., 2010; Porto-Fett et al., 2010), cheese (Soni et al., 2012) or cooked cured ham (Stopforth et al., 2010). The application of LAE for the purposes of salmon preservation has been reported to require a higher dose than the maximum allowed, $200 \mathrm{ppm}$, since its partitioning into the lipid phase reduces the molecules available for direct contact with bacteria (Kang et al., 2014). Its inclusion in a food compatible polymer matrix could mitigate this problem, making the active more effective through its controlled release to the potentially contaminated product surface. 
The aim of the present study was to characterize antimicrobial films based on oxidized corn starch and bovine gelatin, by analysing the effect of LAE incorporation on the film functional properties, as well as to study the effectiveness of the films at controlling microbial growth (with special emphasis on the antilisterial activity) in marinated salmon and at extending its shelf life.

\section{MATERIALS AND METHODS}

\subsection{Materials}

Films were formulated with corn starch (Roquette Laisa España, S.A.), bovine gelatin type A (Sancho de Borja, S.L., Zaragoza, Spain), etil-lauroil-arginate (LAE) at $10 \% \mathrm{wt}$ in ethanol (Vedeqsa, Lamirsa, Terrassa, Spain), and glycerol as plasticizer (Panreac Química S.A., Castellar de Vallès, Barcelona, Spain). Sodium periodate (Sigma-Aldrich, Madrid, Spain) was used for starch oxidation purposes. Controlled relative humidity was achieved with saturated solutions of magnesium nitrate and potassium chloride (Panreac Química S.A., Castellar de Vallès, Barcelona, Spain). For the microbiological assays, Tryptic Soy Broth (TSB), Palcam Agar Base, Agar Bacteriological, Violet Red Bilis Agar and Buffered Peptone Water were supplied by Scharlab (Barcelona, Spain). Listeria innocua (CECT 910) was supplied by Colección Española de Cultivos Tipo (CECT, Burjassot, Valencia, Spain).

\subsection{Film preparation}

Prior to obtaining the film, starch was oxidized following a modification of the method described by Wang et al. (2015), using sodium periodate as oxidizing agent. Starch was dispersed in distilled water (10\% wt.) and sodium periodate was added at a 1:1 molar ratio with respect to the glucose units. Once the components were mixed, the solution reached a value of $\mathrm{pH} 3.5$. After $4 \mathrm{~h}$ under magnetic stirring in the dark, keeping the solution at $35^{\circ} \mathrm{C}$, the dispersion was vacuum filtered (MZ 2C NT, Vacuubrand GMBH+ 
CO KG, Wertheim, Germany) to stop the reaction. The filtrate was washed with distilled water at $8000 \mathrm{rpm}$ (Ultraturrax T25, Janke and Kunkel, Germany) for 30 seconds and newly vacuum filtrated. The washing process was repeated three times. The final filtrate (OS), whose moisture content was determined gravimetrically, was used for film formulation purposes.

Two film formulations were prepared, both of them based on a 1:1 mass blend of oxidized starch (OS) and bovine gelatin (BG), using glycerol ( $0.25 \mathrm{~g} / \mathrm{g}$ polymer blend) as plastizicer. This control formulation was referred to as $O S: B G$, and the active formulation (OS:BG:LAE) included $1.3 \mathrm{~g}$ of LAE per $100 \mathrm{~g}$ of polymer blend. This concentration of LAE was defined in order not to exceed the legal limit (200 ppm) when released into the food. This limit for LAE was established for different food products, including salmon (EFSA journal 2013; Khang et al., 2014).

In order to obtain the film-forming dispersions, OS was dispersed in distilled water (2\% wt.) and gelatinization was induced by heating in a bath at $99^{\circ} \mathrm{C}$ for 1 hour, under stirring. The dispersion was then cooled down to room temperature. Separately, BG was dispersed in water at $2 \%$ (wt.) under magnetic stirring at $40^{\circ} \mathrm{C}$. OS and BG dispersions were mixed and glycerol was added, thus obtaining formulation OS:BG. LAE was afterwards added to this dispersion to obtain OS:BG:LAE. Both formulations were finally vacuum degasified.

The films were obtained by casting the mass of film-forming dispersion containing $1.5 \mathrm{~g}$ of solids per casting plate (15 cm diameter). After drying for $48 \mathrm{~h}$ at $45 \% \mathrm{RH}$ and $25^{\circ} \mathrm{C}$, the films were peeled off and conditioned for one week at either 53 or $88 \% \mathrm{RH}$, using saturated solutions of magnesium nitrate or potassium chloride, respectively. $53 \% \mathrm{RH}$ may be a common storage condition for the films, but when applied to intermediate moisture content products, such as marinated salmon, films will quickly equilibrate with the product aw, until their properties reach values near to those determined in the higher $\mathrm{RH}$ conditioned films.

\subsection{Film characterization}

\subsubsection{Moisture content and Water vapour permeability (WVP)}

Moisture content was gravimetrically determined in six replicates per formulation. The samples were desiccated in two steps; firstly, in a convection oven $\left(60^{\circ} \mathrm{C}, 24 \mathrm{~h}\right)$ and, 
secondly, in cabinets containing $\mathrm{P}_{2} \mathrm{O}_{5}$, until constant mass was reached. Results were expressed as $\mathrm{g}$ of water per $100 \mathrm{~g}$ of dry film.

Water vapour permeability was measured following a modification of the gravimetrical method ASTM E96-95 (McHugh et al., 1993) using Payne permeability cups (Elcometer SPRL, Hermelle/s Argenteau, Belgium) of $3.5 \mathrm{~cm}$ in diameter. To this end, six circular samples per formulation were cut, and their thickness was measured at six points per sample (Electronic Digital Micrometer, Comecta S.A., Barcelona, Spain). WVP was determined at $5{ }^{\circ} \mathrm{C}$ and two water vapour gradients, namely $53-100 \%$ and $88-100 \%$. The $\mathrm{RH}$ was attained using saturated solutions (magnesium nitrate or potassium chloride) and pure water. The side of the film which was in contact with air during drying was oriented towards the gas phase at the lowest $\% \mathrm{RH}$. The cups were weighed every $1.5 \mathrm{~h}$, for $24 \mathrm{~h}$ with an analytical balance (ME36S Sartorius, Germany). After the steady state was reached, the slope obtained from the weight loss vs. time was used to calculate WVP as previously described (Jiménez et al., 2012b).

\subsubsection{Optical properties: transparency, colour and gloss}

Once conditioned at either 53 or $88 \%$ RH for 1 week, and after 5 months' storage at 53 $\% \mathrm{RH}$, the reflectance spectra of the films were obtained on both black and white backgrounds, by using a spectrocolorimeter (CM-3600d, Minolta Co., Tokyo, Japan). From these spectra, the infinite reflectance and internal transmittance ( $\mathrm{Ti}$ ) of the films were obtained by applying the Kubelka-Munk theory for multiple scattering (Hutchings, 1999), as described in previous studies (Atarés et al., 2010). Six replicates per formulation were considered, and the measurements were taken on the surface in contact with air during drying. CIE-L*a*b* coordinates (lightness, Lab*; chrome, Cab* and hue, hab*) of the films were obtained from the infinite reflectance spectra using D65 illuminant $/ 10^{\circ}$ observer.

The film gloss was measured at a $60^{\circ}$ incidence angle, following the ASTM standard D523 (ASTM, 1999), using a flat surface gloss meter (Multi-Gloss 268, Minolta Co., Tokyo, Japan). After 1 week of conditioning at 53 or $88 \mathrm{RH}$, three films per formulation were placed on a matte black surface, and five measurements per sample were taken on the film side in contact with air during drying. The results were expressed as gloss units relative to a highly polished surface of black glass standard with a value near to 100 . 


\subsubsection{In vitro antimicrobial activity of the films}

The antimicrobial activity of the films was analysed using the Gram positive bacterium Listeria innocua (CECT 910). Prior to all assays, the strain, which was initially kept frozen in TSB with $30 \%$ glycerol, was regenerated by inoculating a loopful in $10 \mathrm{~mL}$ TSB. After incubation $\left(24 \mathrm{~h}\right.$ at $\left.37^{\circ} \mathrm{C}\right), 10 \mu \mathrm{l}$ were transferred into $10 \mathrm{~mL}$ TSB, which was incubated for $24 \mathrm{~h}$ at the same temperature to obtain the work culture with exponential phase cells.

Tubes with $10 \mathrm{~mL}$ of TSB were inoculated with $10^{4} \mathrm{CFU} / \mathrm{mL}$ of L.innocua, diluted from the work culture. After 1 week conditioning and 5 storage months, film samples (OS:BG and OS:BG:LAE), $5.3 \mathrm{~cm}$ in diameter, were introduced into the inoculated tubes; inoculated tubes without film were used as a control. All of the tubes were incubated at $37{ }^{\circ} \mathrm{C}$ for $24 \mathrm{~h}$. Bacterium counts were performed at different times of incubation; initial time (after $1 \mathrm{~h}$ of contact), 5 and $24 \mathrm{~h}$. Palcam agar was used as the specific medium for Listeria. All of the tests were run in duplicate.

\subsection{Preparation and characterization of salmon samples}

Fresh salmon was purchased in a local supermarket. Sucrose and sodium chloride (1:1 mass proportion) were mixed homogeneously. Salmon steaks were covered with this mixture (1:1 mass ratio salmon:mixture) on both sides and wrapped in plastic film. Weight $\left(2 \mathrm{~kg}\right.$ ) was applied to favour leaking, and salmon was kept at $5{ }^{\circ} \mathrm{C}$ for $48 \mathrm{~h}$. After this, steaks were peeled and cross-sliced diagonally ( $4 \mathrm{~mm}$ thickness). Circular samples $(5.3 \mathrm{~cm}$ diameter, $10 \pm 0.5 \mathrm{~g}$ ) were cut from these slices for microbial tests. All of the samples were vacuum packaged and stored at $-20^{\circ} \mathrm{C}$ until analyses.

\section{Physicochemical characterization}

Marinated salmon was characterized as to its moisture content, water activity (aw), pH and colour, in comparison to fresh salmon. The moisture content $(\mathrm{g}$ of water per $100 \mathrm{~g}$ of salmon) was gravimetrically quantified in six replicates (5-10 g each) using an analytical balance (ME36S Sartorius, Germany), by desiccation in a vacuum oven at $60{ }^{\circ} \mathrm{C}$. Water activity and $\mathrm{pH}$ were determined in 6 replicates using a Dew Point Water Activity Meter 4TE (Lérida, Spain) and a pH meter (Mettler Toledo Seven Easy pH meter, Switzerland), 
respectively. The optical properties of marinated salmon were measured in the same way as the films (section 2.3.2.)

\section{Microbiological characterization}

Initial microbiological quality (Coliforms and Total viable Counts (TVC)) was determined in $10 \mathrm{~g}$ samples taken from random regions of the marinated salmon fillets. These were aseptically placed inside a stomacher filter bag with $90 \mathrm{~mL}$ of already sterilized buffer peptone water and homogenized for 90 seconds in Stomacher (Bag Mixer 400, Interscience). The obtained homogenate was ten-fold diluted in TSB media and plated out. TVC were determined in Plate Count Agar incubated at $30^{\circ} \mathrm{C}$ for $72 \mathrm{~h}$, while coliforms were determined in Violet Red Bile Agar incubated at $37^{\circ} \mathrm{C}$ for $48 \mathrm{~h}$. All of the tests were run in triplicate.

\subsection{In vivo antimicrobial activity of the films}

\subsubsection{Antimicrobial activity against Listeria innocua in marinated salmon}

Marinated salmon samples (10 g each) were placed in sterile Petri dishes $(5.3 \mathrm{~cm}$ of diameter), inoculating Listeria innocua (102 CFU/cm2) on the sample surface. All of the samples were completely coated using both film formulations (OS:BG and OS:BG:LAE) conditioned at $88 \% \mathrm{RH}$ for 1 week until reach similar aw values to salmon samples were reached. Uncoated, inoculated samples were used as control. Bacterial growth was monitored throughout the storage of the salmon samples at $5{ }^{\circ} \mathrm{C}$ for 45 days. To this end, each sample was aseptically removed from the dish and homogenized in Stomacher with $90 \mathrm{~mL}$ of peptone water for 90 seconds. Ten-fold dilutions were made and poured onto agar PALCAM, prior to incubation at $37^{\circ} \mathrm{C}$ for $48 \mathrm{~h}$. Each film formulation was tested in duplicate.

\subsubsection{Shelf-life of packaged marinated salmon}

Marinated salmon samples of $5.3 \mathrm{~cm}$ in diameter were vacuum packaged in the obtained films ( 1 week conditioned at $88 \mathrm{RH}$ ), and stored for 45 days at $5{ }^{\circ} \mathrm{C}$, in order to monitor the preservation ability of the films during storage time. Control samples were vacuum packaged in conventional vacuum polyamide/low density polyethylene (PA/LDPE) 
plastic, water vapour transmission rate of $2.8 \mathrm{~g} / \mathrm{m}^{2} 24 \mathrm{~h}$ and oxygen permeability rate of $50 \mathrm{~cm}^{3} / \mathrm{m}^{2} 24 \mathrm{~h}$ (La Pilarica S.A., Paterna, Valencia, Spain). The growth of TVC and Coliforms was analysed after 25,35 and 45 days of storage, as described in section 2.4. Each film sample was tested in duplicate.

In parallel, sample weight loss (referred to the initial mass) was also determined in order to control the degree of sample dehydration throughout the whole test, and colour measurements were taken in the salmon samples. This was done as described in section 2.3.2. for the films, directly at four points on the salmon surface. The film was removed and samples were covered with an optical glass. Four samples were considered for the purposes of controlling weight loss and colour at the different storage times,

\subsection{Statistical analyisis}

The statistical analysis of the data was performed through analysis of variance (ANOVA) using Statgraphics Centurion XVI s for Windows 5.1 (Manugistics Corp., Rockville, Md.). Fisher's least significant difference (LSD) at the $95 \%$ confidence level was used to compare treatments.

\section{RESULTS AND DISCUSSION}

\subsection{Physical and antimicrobial properties of the films}

\subsubsection{Moisture and water vapour permeability}

Table 5.1.1 shows the moisture content and WVP values of the films conditioned at either 53 or $88 \% \mathrm{RH}$. Moisture content slightly increased at the highest $\mathrm{RH}$, coherently with the shape of the water sorption isotherms of hygroscopic polymers, since the two $\mathrm{RH}$ levels correspond to different points of the isotherm plateau (Jimenez et al., 2013). LAE incorporation did not cause significant differences in the moisture content of the films $(p>0.05)$. The WVP of the films was higher than that of oil-derived polymers, 
coherently with the hydrophilic nature of starch and gelatin (Prodpran et al., 2007; Avena-Bustillo et al., 2011). The WVP increased significantly at 88-100 \% RH with respect to that at $53-100 \%$ due to the higher mean moisture content in the films in contact with higher $\mathrm{RH}$ levels. Water molecules interact with the film matrix, which leads to a plasticizing effect of the polymer structure and enhances water diffusion across the film. This agrees with what was reported by Jiménez et al. (2012a) for starch films; an increase in the $\mathrm{RH}$ resulted in greater water vapour permeability. Nevertheless, the obtained WVP values were lower than those obtained for starch-gelatin blend films with non-oxidized starch (Moreno, et al., 2016). On the other hand, LAE incorporation did not significantly affect the water barrier properties of the films $(p>0.05)$

Table 5.1.1 Moisture content $\left(X_{w}, g\right.$ water per $100 \mathrm{~g}$ dry film) and water vapor permeability (WVP) of the film samples conditioned at 53 or $88 \% \mathrm{RH}$. RH gradients used for WVP tests are indicated.

\begin{tabular}{|c|c|c|c|}
\hline & RH (\%) & OS:BG & OS:BG:LAE \\
\hline \multirow{2}{*}{$\mathrm{X}_{\mathrm{w}}$ (g water/100 g dry film) } & 53 & $12.9 \pm 1.5^{\mathrm{a}, 1}$ & $12.0 \pm 1.8^{\mathrm{a}, 1}$ \\
\hline & 88 & $16.4 \pm 1.8^{\mathrm{a}, 1}$ & $15.9 \pm 1.9^{\mathrm{a}, 1}$ \\
\hline \multirow{2}{*}{ WVP $\times 10^{7}\left(\mathrm{~g} \cdot \mathrm{mm} / \mathrm{kPa} \cdot \mathrm{h} \cdot \mathrm{m}^{2}\right)$} & $53-100$ & $3.1 \pm 0.3^{\mathrm{a}, 1}$ & $3.2 \pm 0.5^{\mathrm{a}, 1}$ \\
\hline & $88-100$ & $6.6 \pm 0.9^{\mathrm{a}, 2}$ & $5.8 \pm 0.3^{\mathrm{a}, 2}$ \\
\hline
\end{tabular}

Different letters in the same raw indicate significant differences due to LAE incorporation $(p<0.05)$.

Different numbers $(1,2)$ in the same column indicate significant differences due to $\mathrm{RH}(\mathrm{p}<0.05)$.

\subsubsection{Optical properties: transparency, colour and gloss}

Table 5.1.2 shows the optical parameters of the films, namely the colour coordinates, lightness $\left(\mathrm{Lab}^{*}\right)$, chrome $\left(\mathrm{Cab}^{*}\right)$ and hue $\left(\mathrm{hab}^{*}\right)$, internal transmittance $(\mathrm{Ti})$ at $430 \mathrm{~nm}$ and gloss at $60^{\circ}$. Both the increase in $\mathrm{RH}$ and $\mathrm{LAE}$ incorporation had a slight, but statistically significant $(p<0.05)$, effect on the colour of the films. As the $\mathrm{RH}$, and hence the moisture content, grew higher, lightness and hue were slightly reduced and chrome was increased $(p<0.05)$. The same effect was observed as a consequence of LAE incorporation. These changes suggest the progression of browning reactions between the carbonyl groups of OS and the amino groups of gelatin and LAE, thus yielding brown products, such as Maillard compounds. As water availability increases (high RH), molecular mobility is promoted and, hence, carbonyl-amino can take place to a larger extent. Moreover, the small molecular size of LAE may enhance its reactivity, which 
would boost the browning process. In agreement with the colour changes, the internal transmittance of the films at low wavelength was reduced by LAE incorporation, which was further enhanced at high $\mathrm{RH}$. This is the result of the greater light absorption of the brown compounds between 400 and $500 \mathrm{~nm}$.

Film gloss is related with the smoothness of the film surface after drying (Ward et al., 1997). All of the films had gloss values of under 60, hence they could be described as only slightly glossy. Both LAE addition and the highest $\mathrm{RH}$ produced some gloss changes, which may be due to little changes in the surface microstructure. However, considering the variability of the gloss values, this trend could not be considered as relevant.

Table 5.1.2 Optical parameters (lightness $\left(L^{*}\right)$, chrome $\left(C_{a b}{ }^{*}\right)$, hue $\left(h_{a b}{ }^{*}\right)$ ), internal transmittance $\left(T_{i}\right)$ at $430 \mathrm{~nm}$ and gloss at $60^{\circ}$ of films conditioned at 53 and $88 \% \mathrm{RH}$.

\begin{tabular}{|c|c|c|c|}
\hline & RH (\%) & OS:BG & OS:BG:LAE \\
\hline \multirow{2}{*}{$L^{*}$} & 53 & $75.5 \pm 0.4^{\mathrm{b}, 2}$ & $73.4 \pm 0.8^{a, 2}$ \\
\hline & 88 & $74.5 \pm 0.2^{\mathrm{b}, 1}$ & $69.8 \pm 0.6^{a, 1}$ \\
\hline \multirow{2}{*}{$\mathrm{C}_{\mathrm{ab}}{ }^{*}$} & 53 & $32.4 \pm 0.7^{b, 1}$ & $34.4 \pm 0.3^{\mathrm{a}, 1}$ \\
\hline & 88 & $35.2 \pm 0.9^{b, 2}$ & $36.3 \pm 0.3^{a, 2}$ \\
\hline \multirow{2}{*}{$\mathrm{h}_{\mathrm{ab}}{ }^{*}$} & 53 & $79 \pm 0.03^{b, 2}$ & $77.2 \pm 0.2^{\mathrm{a}, 2}$ \\
\hline & 88 & $78.5 \pm 0.5^{\mathrm{b}, 1}$ & $75.9 \pm 0.3^{\mathrm{a}, 1}$ \\
\hline \multirow{2}{*}{$\mathrm{T}_{\mathrm{i}}(430 \mathrm{~nm})$} & 53 & $0.695 \pm 0.009^{b, 1}$ & $0.577 \pm 0.007^{a, 1}$ \\
\hline & 88 & $0.606 \pm 0.017^{\mathrm{b}, 2}$ & $0.525 \pm 0.012^{\mathrm{a}, 2}$ \\
\hline \multirow{2}{*}{ Gloss $\left(60^{\circ}\right)$} & 53 & $57 \pm 9^{\mathrm{b}, 1}$ & $21 \pm 10^{\mathrm{a}, 1}$ \\
\hline & 88 & $25 \pm 5^{b, 2}$ & $33 \pm 8^{a, 2}$ \\
\hline
\end{tabular}

Different letters $(a, b)$ in the same raw indicate significant differences due to LAE incorporation $(p<0.05)$.

Different numbers $(1,2)$ in the same column indicate significant differences due to $\mathrm{RH}(p<0.05)$.

The extent of the browning reactions in the films throughout the conditioning time at 53 $\% \mathrm{RH}$ was assessed through the colour development. After 5 months' conditioning, the lightness of OS:BG films was significantly reduced to $65.7 \pm 1.6$, at the same time as hue changed from $79.2 \pm 0.3$ to $76.3 \pm 1.3$ and colour saturation increased from $32.4 \pm 0.7$ to $37.9 \pm 1.9(p<0.05)$. These changes point to the progression of the carbonyl-amino 
condensation reaction throughout storage time and the progressive formation of Maillard compounds. Browning progressed to greater extent in LAE-free films and no significant differences were observed as regards the colour parameters of films with and without LAE after 5 storage months.

\subsubsection{In vitro antimicrobial activity of the films.}

Table 5.1.3 shows the results obtained for the analysis of the antimicrobial effectiveness of the films after different storage times at $53 \% \mathrm{RH}: 1$ week and 5 months. Both control films without LAE exhibited antimicrobial ability at controlling the growth of L.innocua, after 5 and $24 \mathrm{~h}$ of incubation at $37^{\circ} \mathrm{C}$; this was attributed to the Maillard compounds resulting from the carbonyl-amino reaction, which have previously been reported to show antimicrobial activity (Hauser et al., 2014; Wu et al., 2014). More specifically, Hauser et al. (2014) demonstrated that films with Maillard products showed strong antimicrobial activity through different mechanisms, such as the generation of hydrogen peroxide; while Einarsson et al. (1983) observed that these compounds exhibited a greater inhibitory effect against Gram positive bacteria than against Gram negative. In addition, the enhancement of the browning reaction in the films during storage time, as previously commented on, yielded a greater formation of Maillard compounds and, as a result, the antimicrobial effectiveness of the LAE-free films after 5 months of storage increased in comparison with that of films stored for 1 week. The listeria inhibition growth, in terms of log reduction with respect to the control sample, were 2.38 and $1.68 \mathrm{CFU} / \mathrm{mL}$, respectively for films stored for 1 week and 5 months. The incorporation of LAE into the films led to a total bactericidal effect at all the incubation times tested. The minimally inhibitory concentration (MIC) of LAE reported against Listeria monocytogenes was 8 $\mu \mathrm{g} / \mathrm{mL}$ (Higueras et al., 2013), and the concentration reached in the medium, assuming a total release from the films, would be $200 \mu \mathrm{g} / \mathrm{mL}$. Therefore, the MIC value would be exceeded in the culture medium, acting against the microbial cells effectively. 
Table 5.1.3 Effect of the films, conditioned for 1 week and 5 months at $53 \% \mathrm{RH}$, on the growth and survival of Listeria innocua (CECT 910) at $37^{\circ} \mathrm{C}$. Bacterial counts obtained at initial time (less than $1 \mathrm{~h}$ contact), 5 and $24 \mathrm{~h}$ of incubation. Average values and standard deviation.

\begin{tabular}{cccc}
\hline \multirow{2}{*}{ Formulation } & Initial time & 5h & 24h \\
& Log (CFU/mL) & $\log (\mathrm{CFU} / \mathrm{mL})$ & $\log (\mathrm{CFU} / \mathrm{mL})$ \\
\hline Control Listeria & $4.33 \pm 0.09^{\mathrm{a}, 1}$ & $6.59 \pm 0.06^{\mathrm{b}, 2}$ & $8.78 \pm 0.05^{\mathrm{b}, 3}$ \\
\hline OS:BG 1 week & $4.37 \pm 0.09^{\mathrm{a}, 1}$ & $4.6 \pm 0.4^{\mathrm{a}, 1}$ & $7.099 \pm 0.007^{\mathrm{a}, 2}$ \\
\hline OS:BG 5 months & $4.307 \pm 0.106^{\mathrm{a}, 1}$ & $4.1 \pm 0.6^{\mathrm{a}, 1}$ & $6.4 \pm 1.0^{\mathrm{a}, 2}$ \\
\hline OS:BG:LAE 1 week & $\mathrm{NDG}^{*}$ & $\mathrm{NDG}^{*}$ & $\mathrm{NDG}^{*}$ \\
\hline OS:BG:LAE 5 months & NDG $^{*}$ & $\mathrm{NDG}^{*}$ & $\mathrm{NDG}^{*}$ \\
\hline
\end{tabular}

Different letters $(a, b)$ in the same column indicate significant differences among the different formulations $(p<0.05)$.

Different numbers $(1,2,3)$ in the same row indicate significant differences among the different times of incubation for the same formulation $(p<0.05)$.

${ }^{*}$ No Detected Growth.

\subsection{Film application to extend shelf-life of marinated salmon.}

\subsubsection{Physicochemical and microbiological properties of salmon samples}

A physicochemical and microbiological characterization of the marinated salmon samples was carried out. Moisture content, water activity and $\mathrm{pH}$ were significantly reduced $(p<0.05)$ after marinating with respect to the values of fresh salmon, reaching values of $52.4 \pm 0.8 \mathrm{~g}$ water $/ \mathrm{g}$ salmon, $0.925 \pm 0.017$ and $5.98 \pm 0.03$, respectively. In contrast, these values for fresh salmon were $70 \pm 4 \mathrm{~g}$ water/g salmon, $0.988 \pm 0.000$ and $6.21 \pm 0.13$, respectively. Coherently with the fish's osmotic dehydration and the solute gain (sucrose and sodium chloride) in contact with the sucrose-salt mixture, a moisture reduction occurred, and the aw value and $\mathrm{pH}$ fell too. Linked to these changes, the concentration of pigments increased in the tissue, thus modifying the selective light absorption properties of the muscle (Sánchez-Zapata et al., 2008). Therefore, in comparison with the colour coordinates of fresh salmon (data not shown), whereas the hue of salmon (45 \pm 4 ) was not significantly affected after marinating, lightness (38 \pm 2 ) and colour saturation (chrome: $16 \pm 2$ ) were significantly reduced, as previously reported by other authors (Cardinal et al., 2001, Lerfall and Rotabakk, 2015. These colour changes could be visually appreciated. 
As regards the initial microbiological quality, marinating did not affect the microbial flora of the fresh salmon. No Coliforms were detected either in fresh or marinated salmon and TVC were $3.8 \pm 0.5 \log$ CFU/g, thus indicating good hygienic fish handling practices (legal limit: $10^{6} \mathrm{cfu} / \mathrm{g}$ ).

\subsubsection{In vivo antilisterial activity of the films in marinated salmon}

Figure 5.1.1 shows the counts of Listeria innocua in inoculated marinated salmon samples coated with OS:BG and OS:BG:LAE films, as well as those of uncoated samples (control) throughout the storage time under refrigeration conditions $\left(5^{\circ} \mathrm{C}\right)$. The application of both films entailed some growth reduction in comparison with the control sample. During the first 25 storage days, the LAE presence in the films did not imply significant differences in the listeria counts. However, at the end storage time (45 days), the growth inhibition with respect to the control was significantly greater $(p<0.05)$ for the samples coated with OS:BG films (1.87 log CFU/g of reduction with respect to the control sample) than for those coated with the OS:BG:LAE film (0.98 log CFU/g). Hence, the incorporation of LAE into the films did not result in an improved antilisterial activity in salmon samples, despite the stronger activity observed in the in vitro test for OS:OB:LAE films. Assuming a total release of the active, its more limited antilisterial action in salmon could be attributed to the predominant partitioning of the compound in the fat phase, thus making it unable to act against the bacteria prevalent in the aqueous phase, as previously reported (Kang et al., 2014). The specific interactions with the complex food matrix limited the antimicrobial action of the compound. The antimicrobial action of the active compounds is affected not only by the target microorganisms, but also by a wide number of factors associated to the food composition, such as $\mathrm{pH}$, water activity, fat and protein contents, or its nature microflora (Han, 2005). Many antimicrobials (such as chitosan, nisin, LAE and $\varepsilon$-polylysine) have been tested against Listeria in salmon (Kang et al., 2014) and, in spite of the numerous studies demonstrating their efficacy in other food products, such as fresh cheese (Soni et al., 2012), cured ham (Stopforth et al., 2010) and Frankfurt style sausages (Martin et al., 2010), antilisterial activity has not been found when directly applied to salmon. This has been attributed to the effective distribution of the antimicrobial compound in the fat phase of the fish, thus reducing its availability for antimicrobial action (Kang et al., 2014). The obtained results suggest that the inclusion of LAE in the OS:BG films did not enough effective to limit its migration into the fat phase, in order to enhance its antimicrobial action in salmon samples. However, the active compounds generated in OS:BG films were effective at controlling the listeria 
growth in salmon in the same way as that observed for in vitro tests. Active Maillard compounds and the potentially generated hydrogen peroxide are water-soluble and can act against bacteria, inhibiting their growth during a long period of time. In fact, compared with the initial counts, no growth was observed after 25 storage days,

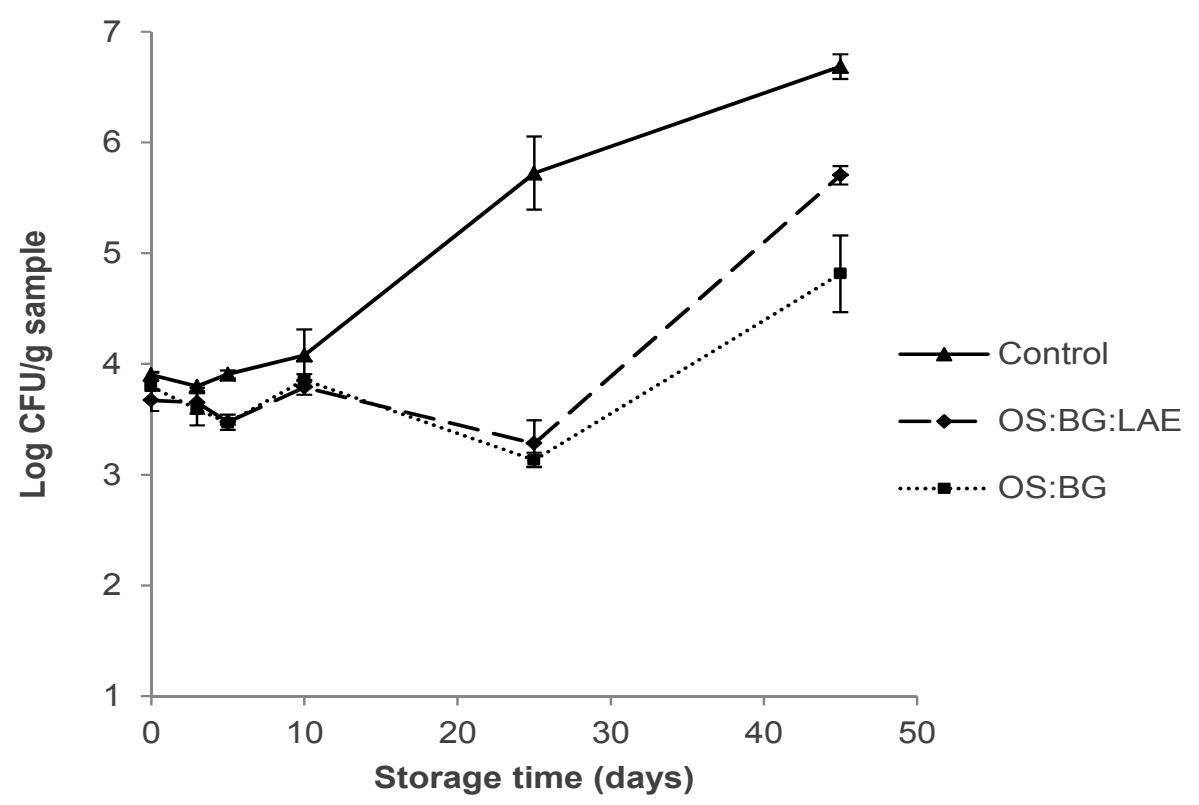

Figure 5.1.1 Microbial counts obtained at initial time, 3, 5, 10, 25 and 45 days of storage of marinated salmon kept at $5^{\circ} \mathrm{C}$ inoculated with Listeria innocua, either without film coating (Control) or completely coated with both film formulations (OS:BG and $\mathrm{OS}: \mathrm{BG}: \mathrm{LAE}$ ) conditioned for 1 week at $88 \% \mathrm{RH}$. Mean values and standard deviation.

\subsubsection{Shelf-life of packaged marinated salmon}

The shelf life of marinated salmon samples, vacuum packaged in the OS:BG biodegradable films was compared to that of samples packaged in commercial synthetic plastic (control). Coliform counts were not detectable in any case. Figure 5.1.2 shows the results of TVC counts over 45 storage days at $5{ }^{\circ} \mathrm{C}$. 


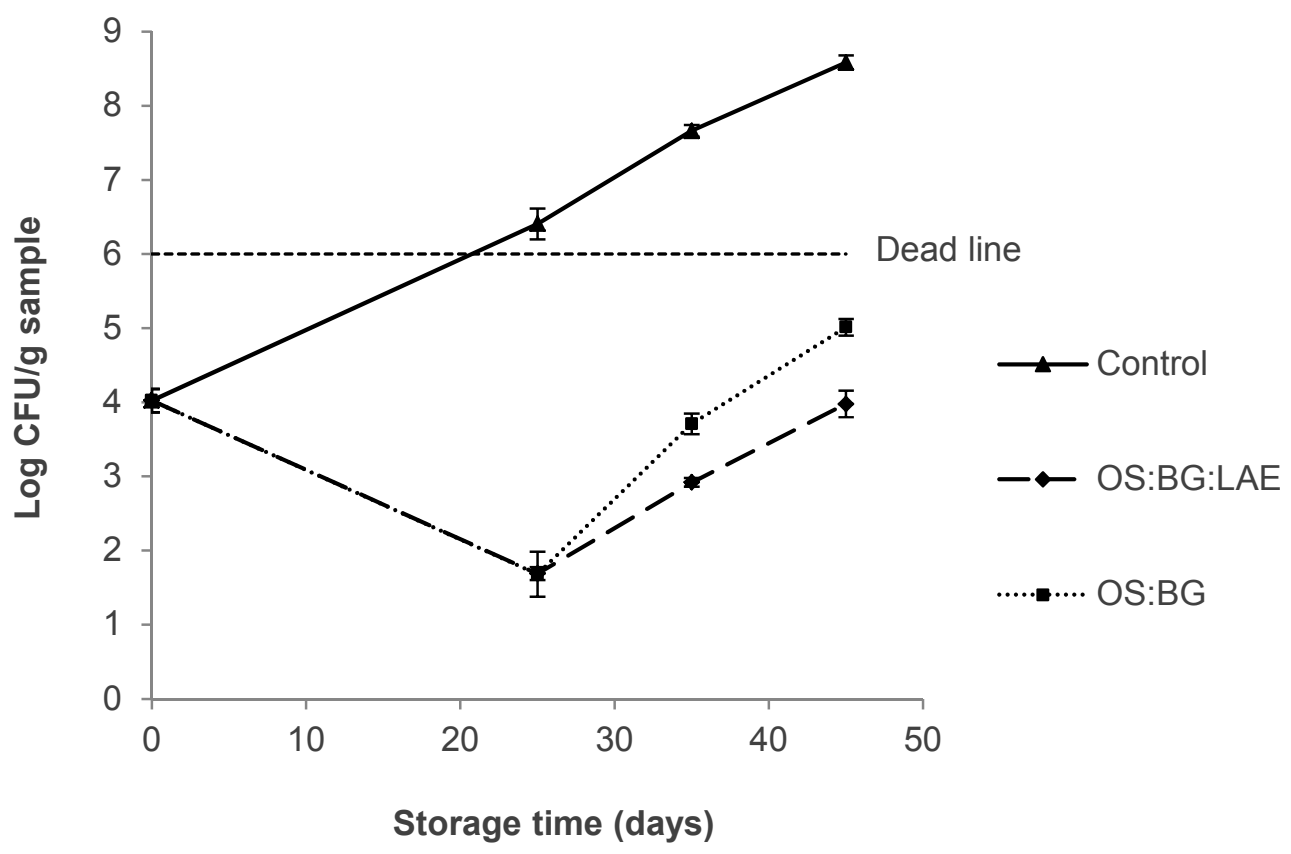

Figure 5.1.2 TVC counts obtained at initial time, 3, 25, 35 and 45 days of storage of marinated salmon at $5{ }^{\circ} \mathrm{C}$, vacuum packaged in commercial synthetic plastic (Control), or with both film formulations (OS:BG and OS:BG:LAE) conditioned for 1 week at $88 \% \mathrm{RH}$.

Mean values and standard deviation.

The application of both kinds of films (with and without LAE) resulted in a reduced cell population as compared to the control sample. In the early stages of the test, a similar bactericidal effect of both OS:BG and OS:BG:LAE films was observed, which suggests the Maillard products were prevalent in the antimicrobial action, since no LAE was present in OS:BG films. After 25 days, the population of TVC bacteria exceeded the established legal limit $\left(10^{6} \mathrm{CFU} / \mathrm{g}\right)$ for control samples, whereas a marked count reduction (4.7 log CFU/g) was observed for samples packaged in OS:BG films with and without LAE with respect to the control. Therefore, although the bacterial population in marinated salmon samples packaged in OS:BG and OS:BG:LAE films remained under the legal limit throughout the entire test, after 25 days of storage, a greater growth inhibition was observed for films containing LAE. More specifically, at the end of storage, OS:BG:LAE packaged samples exhibited a reduction with respect to the legal limit of $2 \log$ CFU/g, in comparison with the $1 \log$ CFU/g of reduction for OS:BG packaged samples. The antimicrobial effectiveness of the films against the natural microflora of marinated salmon seems to be enhanced by the presence of LAE, but this effect was only appreciated after a long storage time. 
However, despite the good antimicrobial properties of the films, they were not effective at controlling the moisture loss of the samples due to their relatively high WVP values (Table 5.1.1). In fact, whereas no mass loss occurred in the control sample, packaged in the conventional plastic film, samples packaged in OS:BG films exhibited a linear mass loss in line with the storage time; the slope was 0.0027 day $^{-1}$ and 0.0021 day $^{-1}$ ,respectively, for samples in films with and without LAE, with a final mass loss of nearly $10 \%$ in the samples. This mass loss implied a progressive reduction in both the product moisture content and aw, mainly at surface level, which also affected the sample colour and could also contribute to the antimicrobial activity of the films (combined hurdles). This can have an impact on the product's organoleptic properties, such as juiciness, as well as on the product's appearance through their effect on the optical properties.

Figure 5.1 .3 shows the development of the colour attributes for the different salmon samples packaged in the conventional and developed films throughout the storage time. Whereas no significant changes in colour coordinates were observed for the control samples, taken the variability in the values into account, the samples packaged in $O S: B G$ films, with and without $L A E$, exhibited similar significant reduction in lightness. This can be mainly attributed to the above mentioned water loss that occurred in both kinds of samples. For samples packaged in OS:BG films with LAE, no significant changes in either hue or colour saturation (chrome) occurred during storage; however, in the samples in contact with films without LAE, a significant increase in hue and chrome values occurred after 25 days of storage, which points to a certain discoloration effect. However, subsequent changes lead these colour parameters closer to the initial values. The potential oxidation of the salmon pigments, such as carotenoids, could explain this initial development, and this effect on the colour could be subsequently mitigated by the progressive water loss, which enhanced the concentration of the natural pigments. At the end of storage ( 45 days), the differences in the sample lightness are the main factor that contribute to the total colour difference with respect to the initial sample. These values were $6 \pm 3$ for plastic packaged samples, close to the natural variability in the samples, and $11 \pm 5$ and $16 \pm 6$, respectively, for samples in contact with OS:BG and OS:BG:LAE films. Therefore, despite the good antimicrobial properties of the OS:BG films, their ability to preserve the quality of salmon during storage are compromised by their poor water vapour barrier properties, which in turn, affect the product lightness imparting a non-acceptable colour difference (Hutchings, 1999) with respect to the initial product. In consequence, a multilayer film, including a high water vapour barrier layer, would be necessary to guarantee the quality of the marinated salmon throughout such a lengthy 
storage period. Other quality parameters, such as fat oxidation and sensory properties, must also be assessed in the multilayer-film packaged sample.
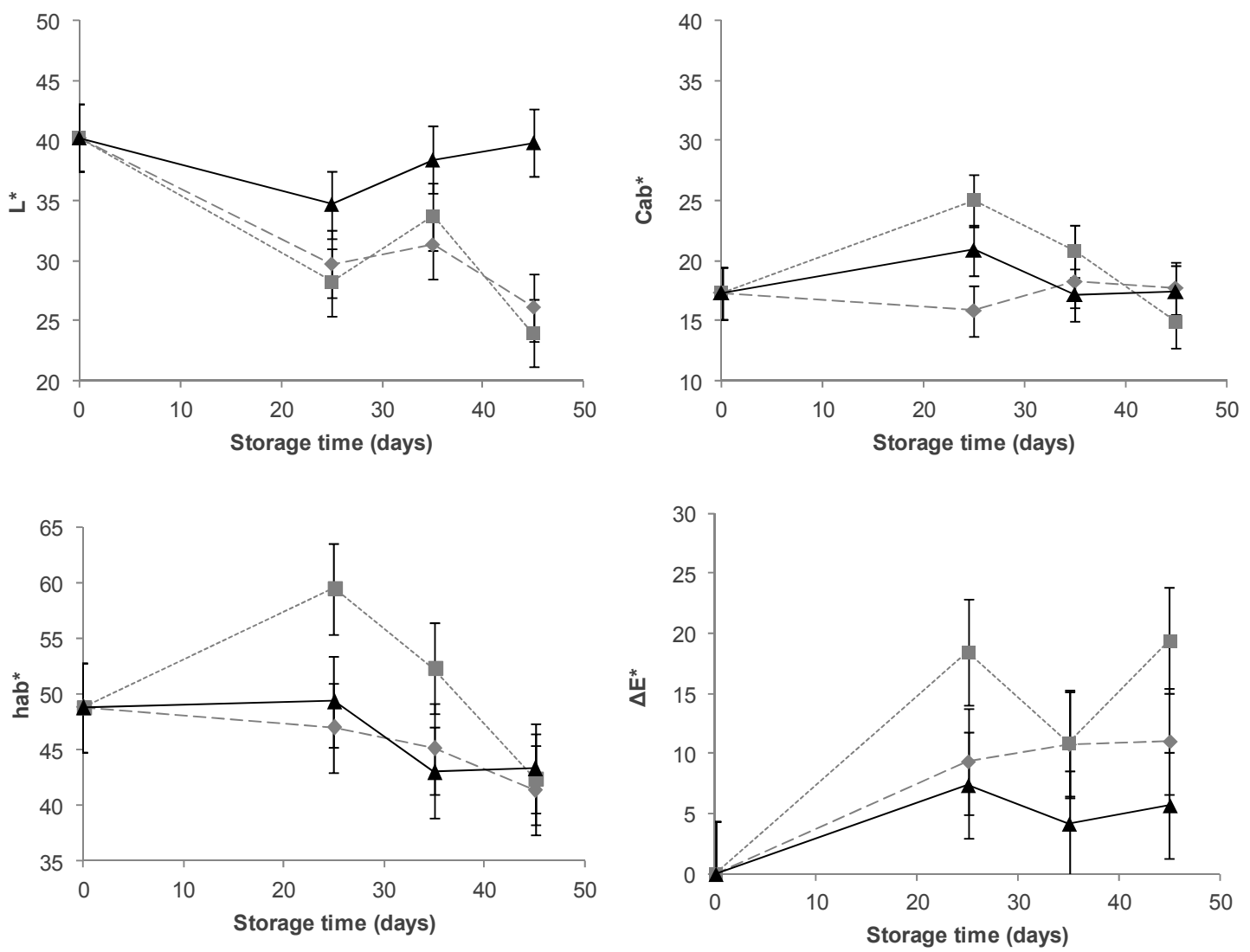

-- OS:BG:LAE

$O S: B G$

$\leftarrow$ Control

Figure 5.1.3 Development of colour parameters (lightness, $L^{*}$; chrome, $\mathrm{C}_{a b}{ }^{*}$; hue, $\mathrm{h}_{\mathrm{ab}}{ }^{*}$ ) and total colour difference $(\Delta \mathrm{E})$ with respect to the initial colour of marinated salmon vacuum packaged throughout the storage time at $5^{\circ} \mathrm{C}$. Bars correspond to the LSD intervals (95\% confidence level). 


\section{CONCLUSIONS}

xidized starch-gelatin blend films, with and without LAE, were highly effective at controlling microbial growth, exhibiting antilisterial activity in marinated salmon samples, greatly extending the product shelf life in terms of microbial spoilage. However, the films exhibited high values of water vapour permeability, which implied a weight loss of about $10 \%$ in salmon samples packaged for 45 days. The films exhibited browning mainly when stored at a high relative humidity or when containing LAE due to the carbonyl-amino reactions and the formation of Maillard compounds, which have antimicrobial activity. These reactions progressed during storage, increasing the antimicrobial power. LAE incorporation provoked a total bactericidal effect when tested in vitro against Listeria innocua, although it was not effective in marinated salmon where the antilisterial effect was similar for films with and without LAE. The TVC in salmon samples remained below the legal limit after 45 storage days, which would allow for an extended shelf-life. However, salmon samples underwent darkening in line with desiccation, which affects their quality. Therefore, a multilayer film, with good water vapour barrier properties, would be necessary in order to extend the shelf life in a wider concept, including all of the quality parameters.

\section{Acknowledgements}

The authors acknowledge the financial support provided by Ministerio de Economía y Competividad (Projects AGL2013-42989-R and AGL2016-76699-R). Olga Moreno Marro also thanks the Ministerio de Educación, Cultura y Deporte for the FPU 2012-1121 grant. 


\section{REFERENCES}

Acosta, S., Jiménez, A., Cháfer, M., González-Martínez, C., \& Chiralt, A. (2015). Physical properties and stability of starch-gelatin based films as affected by the addition of esters of fatty acids. Food Hydrocolloids, 49, 135-143.

Acosta, S., Chiralt, A., Santamarina, P., Rosello, J., González-Martínez, C., \& Cháfer, M. (2016). Antifungal films based on starch-gelatin blend, containing essential oils. Food Hydrocolloids, 61, 233-240.

ASTM. (1995). Standard test methods for water vapor transmission of materials. Standard Designations: E96-95. In: Annual Book of American Society for Testing Materials, West Conshohocken, PA, USA.

ASTM. (1999). Standard test methods for specular gloss. Designation (D523): Annual book of American Society for Testing Materials, Philadelphia, PA, USA.

Atarés, L., Bonilla, J., \& Chiralt, A. (2010). Characterization of sodium caseinate-based edible films incorporated with cinnamon or ginger essential oils. Journal of Food Engineering, 100(4), 678-687.

Aubourg S.P., Quitral V., Larraín A., Rodríguez A., Gómez j., Maier L., Vinagre J. (2007). Autolytic degradation and microbiological activity in farmed Coho salmon (Oncorhynchus kisutch) during chilled storage. Food Chemistry, 104, 369-375.

Avena R. J.- Bustillos, B. Chiou, C.W. Olsen, P.J. Bechtel, D.A. Olson., T.H. McHugh. (2011). Gelation, Oxygen Permeability, and Mechanical Properties of Mammalian and Fish Gelatin films. Journal of Food Science, 76, 519-524.

Azeredo, H. M., \& Waldron, K. W. (2016). Crosslinking in polysaccharide and protein films and coatings for food contact-A review. Trends in Food Science \& Technology, 52, 109-122.

Byun, Y., \& Kim, Y. T. (2014). Chapter 14 - Bioplastics for food packaging: Chemistry and physics. In J. H. Han (Ed.), Innovations in food packaging (2nd ed., pp. 353-368). San Diego: Academic Press.

Cazón, P., Velazquez, G., Ramírez, J. A., \& Vázquez, M. (2016). Polysaccharide-based films and coatings for food packaging: A review. Food Hydrocolloids.

Cornu, M., Beaufort, A., Rudelle, S., Laloux, L., Bergis, H., Miconnet, N., Serot, T., DelignetteMuller, M.L. (2006). Effect of temperature, water-phase salt, and phenolic contents on Listeria monocytogenes growth rates on cold-smoked salmon and 
evaluation of secondary models. International Journal of Food Microbiology, 106, 159168.

Davidson, P.M., Taylor, T.M., 2007. Chemical preservatives and natural antimicrobial compounds. In: Doyle, M.P., Beuchat, L.R. (Eds.), Food Microbiology: Fundamentals and Frontiers, third ed. ASM Press, Washington, DC, pp. 713-746.

De Oliveira Pizzoli, A. P., Marchiore, N. G., De Souza, S. J., de Freitas Santos, P. D., Gonçalves, O. H., Yamashita, F., ... \& Leimann, F. V. (2016). Antimicrobial PLA/TPS/gelatin sheets with enzymatically crosslinked surface containing silver nanoparticles. Journal of Applied Polymer Science, 133(8).

Du, Y. L., Cao, Y., Lu, F., Li, F., Cao, Y., Wang, X. L., \& Wang, Y. Z. (2008). Biodegradation behaviors of thermoplastic starch (TPS) and thermoplastic dialdehyde starch (TPDAS) under controlled composting conditions. Polymer Testing, 27(8), 924930.

Einarsson H., Gorang-Snygg B., Eriksson C. (1983). Inhibition of Bacterial Growth by Maillard Reaction Products. Food Chemistry, 31, 1043-1047.

Eklund, M.W., Poysky, F.T., Paranjpye, R.N., Lashbrook, L.C., Peterson, M.E., Pelroy, G.A. (1995). Incidence and sources of Listeria monocytogenes in cold-smoked fishery products and processing plants. Journal of Food Protection, 58, 502-508.

European Food Safety Authority (2013): Analysis of the baseline survey on the prevalence of Listeria monocytogenes in certain ready-to-eat foods in the EU, 2010-2011 Part A: Listeria monocytogenes prevalence estimates. The EFSA Journal, 2013, 11(6).

Fakhouri, F. M., Costa, D., Yamashita, F., Martelli, S. M., Jesus, R. C., Alganer, K., ... \& Innocentini-Mei, L. H. (2013). Comparative study of processing methods for starch/gelatin films. Carbohydrate polymers, 95(2), 681-689.

Han, J. H. (2005). Introduction to active food packaging technologies. In J. H. Han (Ed.), Innovations in food packaging (pp. 80e107). London: Academic Press.

Hauser C., Müller U., Sauer T., Augner K., Pischetsrieder. (2014). Maillard reaction products as antimicrobial components for packaging films. Food chemistry, 145, 603613.

Hawkins,D.R., Rocabayera,X., Ruckman,S., Segret, R., Shaw,D. (2009). Metabolism and pharmacokinetics of ethyl Na-lauroyl-L-arginate hydrochloride in human volunteers. Food and Chemical Toxicology, 47, 2711-2715.

Higueras, L., López-Carballo, G., Hernández-Muñoz, P., Gavara, R., \& Rollini, M. (2013). Development of a novel antimicrobial film based on chitosan with LAE (ethyl-N $\alpha$ dodecanoyl-L-arginate) and its application to fresh chicken. International journal of food microbiology, 165(3), 339-345. 
Hutchings, J. B. (1999). Instrumental specification. In Food colour and appearance (199237 pp). Springer US.

Jiang, Z., Neetoo, H., \& Chen, H. (2011). Efficacy of freezing, frozen storage and edible antimicrobial coatings used in combination for control of Listeria monocytogenes on roasted turkey stored at chiller temperatures. Food Microbiology, 28(7), 1394-1401.

Jiménez, A., Fabra, M. J., Talens, P., \& Chiralt, A. (2012a). Edible and biodegradable starch films: a review. Food and Bioprocess Technology, 5(6), 2058-2076.

Jiménez, A., Fabra, M. J., Talens, P., \& Chiralt, A. (2012b). Effect of re-crystallization on tensile, optical and water vapour barrier properties of corn starch films containing fatty acids. Food Hydrocolloids, 26(1), 302-310.

Jiménez, A., Fabra, M. J., Talens, P., \& Chiralt, A. (2013). Phase transitions in starch based films containing fatty acids. Effect on water sorption and mechanical behaviour. Food Hydrocolloids, 30(1), 408-418.

Kang, J., Stasiewicz, M. J., Murray, D., Boor, K. J., Wiedmann, M., \& Bergholz, T. M. (2014). Optimization of combinations of bactericidal and bacteriostatic treatments to control Listeria monocytogenes on cold-smoked salmon. International journal of food microbiology, 179, 1-9.

Martin, E. M., O’Bryan, C. A., Lary, R. Y., Griffis, C. L., Vaughn, K. L., Marcy, J. A., ... \& Crandall, P. G. (2010). Spray application of liquid smoke to reduce or eliminate Listeria monocytogenes surface inoculated on frankfurters. Meat science, 85(4), 640-644.

Martucci, J. F., \& Ruseckaite, R. A. (2009). Tensile properties, barrier properties, and biodegradation in soil of compression-Molded gelatin-dialdehyde starch films. Journal of Applied Polymer Science, 112(4), 2166-2178.

Masina, N., Choonara, Y. E., Kumar, P., du Toit, L. C., Govender, M., Indermun, S., \& Pillay, V. (2016). A review of the chemical modification techniques of starch. Carbohydrate Polymers.

McHugh, T. H., Avena-Bustillos, R., \& Krochta, J. M. (1993). Hydrophobic edible films: modified procedure for water vapor permeability and explanation of thickness effects. Journal of Food Science, 58(4), 899-903.

Moreno O., Atarés L., Chiralt A., (2015). Effect of the incorporation of antimicrobial/antioxidant proteins on the properties of potato starch films. Carbohydrate Polymers, 133, 353-364

Moreno, O., Díaz, R., Atarés, L., \& Chiralt, A. (2016). Influence of the processing method and antimicrobial agents on properties of starch-gelatin biodegradable films. Polymer International, 65(8), 905-914.

Muriel-Galet, V., López-Carballo, G., Hernández-Muñoz, P., \& Gavara, R. (2014). Characterization of ethylene-vinyl alcohol copolymer containing lauril arginate (LAE) as 
material for active antimicrobial food packaging. Food packaging and shelf life, 1(1), 1018.

Ortega-Toro, R., Jiménez, A., Talens, P., \& Chiralt, A. (2014). Effect of the incorporation of surfactants on the physical properties of corn starch films. Food Hydrocolloids, 38, 6675.

Pereira de Abreu D. A, Paseiro Losada P., Maroto J., Cruz J.M. (2011). Natural antioxidant active packaging film and its effect on lipid damage in frozen blue shark (Prionace glauca). Innovative Food Science and Emerging Technologies, 12, 50-55.

Porto-Fett, A. C. S., Campano, S. G., Smith, J. L., Oser, A., Shoyer, B., Call, J. E., \& Luchansky, J. B. (2010). Control of Listeriamonocytogenes on commercially-produced frankfurters prepared with and without potassium lactate and sodium diacetate and surface treated with lauric arginate using the Sprayed Lethality in Container (SLIC $尺$ ) delivery method. Meat science, 85(2), 312-318.

Prodpran, T., Benjakul, S., \& Artharn, A. (2007). Properties and microstructure of proteinbased film from round scad (Decapterus maruadsi) muscle as affected by palm oil and chitosan incorporation. International Journal of Biological Macromolecules, 41, 605-614.

Rhim, J. W., Gennadios, A., Weller, C. L., Cezeirat, C., \& Hanna, M. A. (1998). Soy protein isolate-dialdehyde starch films. Industrial Crops and Products, 8(3), 195-203.

Rhim, J. W., Park, H. M., \& Ha, C. S. (2013). Bio-nanocomposites for food packaging applications. Progress in Polymer Science, 38(10), 1629-1652.

Rodriguez, E., Seguer, J., Rocabayera, X., \& Manresa, A. (2004). Cellular effects of monohydrochloride of I-arginine, Na-lauroyl ethylester (LAE) on exposure to Salmonella typhimurium and Staphylococcus aureus. Journal of Applied Microbiology, 96(5), 903912.

Salarbashi, D., Mortazavi, S. A., Noghabi, M. S., Bazzaz, B. S. F., Sedaghat, N., Ramezani, M., \& Shahabi-Ghahfarrokhi, I. (2016). Development of new active packaging film made from a soluble soybean polysaccharide incorporating $\mathrm{ZnO}$ nanoparticles. Carbohydrate polymers, 140, 220-227.

Sánchez-García, M.D., Giménez, E., Lagaron, J.M., (2008). Morphology and barrier properties of solvent cast composites of thermoplastic biopolymers and purified cellulose fibers. Carbohydrate. Polymers. 71, 235-244.

Scallan, E., Hoekstra, R. M., Angulo, F. J., Tauxe, R. V., Widdowson, M. A., Roy, S. L., Griffin, P. M. (2011). Foodborne illness acquired in the United States-major pathogens. Emerg Infect Dis, 17.1.

Siracusa, V., Rocculi, P., Romani, S., \& Dalla Rosa, M. (2008). Biodegradable polymers for food packaging: a review. Trends in Food Science \& Technology, 19(12), 634-643.

Soni, K. A., Desai, M., Oladunjoye, A., Skrobot, F., \& Nannapaneni, R. (2012). Reduction of Listeria monocytogenes in queso fresco cheese by a combination of listericidal and 
listeriostatic GRAS antimicrobials. International journal of food microbiology, 155(1), 8288.

Stopforth, J. D., Visser, D., Zumbrink, R., Van Dijk, L., \& Bontenbal, E. W. (2010). Control of Listeria monocytogenes on cooked cured ham by formulation with a lactatediacetate blend and surface treatment with lauric arginate. Journal of food protection, 73(3), 552-555.

Sung, S. Y., Sin, L. T., Tee, T. T., Bee, S. T., Rahmat, A. R., Rahman, W. A. W. A., Tan, A-C \& Vikhraman, M. (2013). Antimicrobial agents for food packaging applications. Trends in Food Science \& Technology, 33(2), 110-123.

Tharanathan, R. N. (2003). Biodegradable films and composite coatings: past, present and future. Trends in Food Science \& Technology, 14(3), 71-78.

Wang y., Zhang Y., Hou C., Qi Z., He X., Li Y. (2015). Facile synthesis of monodisperse functional magnetic dialdehyde starch nano-composite and used for highly effective recovery of $\mathrm{Hg}$ (II). Chemosphere, 141, 26-33.

Ward G., Nussinovitch A. (1997). Characterizing the gloss properties of hydrocolloid films. Food Hydrocolloids, 11(4), 357-365.

Wu Shuping., Hu Jiao., Wei Liuting., Du Y., Shi X., Zhang L. (2014). Antioxidant and antimicrobial activity of Maillard reaction products fron xylan with chitosan/chitooligomer/glucosamine hydrochloride/taurine model systems. Food Chemistry 143, 148-203

Yu, J., Chang, P. R., \& Ma, X. (2010). The preparation and properties of dialdehyde starch and thermoplastic dialdehyde starch. Carbohydrate Polymers, 79(2), 296-300. 


\section{STARCH-GELATIN ANTIMICROBIAL PACKAGING MATERIALS TO EXTEND THE SHELF LIFE OF CHICKEN BREAST FILLETS}

Olga Moreno ${ }^{a *}$, Lorena Atarés ${ }^{a}$, Amparo Chiralt ${ }^{a}$, Malco C. Cruz-Romero ${ }^{b}$, Joseph Kerry ${ }^{\text {b }}$

${ }^{a}$ Departamento de Tecnología de Alimentos - Instituto de Ingeniería de Alimentos para el Desarrollo. Universitat Politècnica de València, Camino de Vera s/n 46022 Valencia, Spain

${ }^{\mathrm{b}}$ Food Packaging Group, School of Food \& Nutritional Sciences, University College Cork, Cork, Ireland 


\section{ABSTRACT}

ntimicrobial starch:gelatin (1:1) films containing LAE (10 \% wt.) were used as food contact active layers in chicken breast fillets vacuum-packaged in polyamide/polyethylene pouches. Active layers were thermoprocessed (TP) or cast $(\mathrm{OC})$ on the plastic film. Oxidized starch was used in OC coatings. Packaged chicken breast samples were stored at $4{ }^{\circ} \mathrm{C}$ and their physicochemical properties $(\mathrm{pH}$, colour and lipid oxidation) and microbial quality were analysed throughout storage. Both TP and OC films significantly $(p<0.05)$ extended the shelf life of chicken breast fillets compared to control samples. While the microbiological shelf life was more extended when OC films were used, they also significantly $(p<0.05)$ promoted lipid oxidation. Oxidation reaction in $\mathrm{OC}$ films promoted browning and the formation of Maillard reaction compounds, which enhanced antimicrobial effectiveness, but also promoted oxidative processes. This greatly affected the $\mathrm{pH}$ and colour parameters of $\mathrm{OC}$ packaged samples. The overall results indicated that TP containing LAE could effectively extend the shelf life of chicken breast fillets without significantly affecting the oxidation of the meat components.

KEYWORDS: LAE, starch, gelatin, antimicrobial, themoprocessed, oxidized coating. 


\section{INTRODUCTION}

tarch has been the subject of extensive study for the purposes of developing packaging materials because it is an abundant, cheap and biodegradable material that is also edible and, thus, adequate for food contact purposes (Cazón, 2016). However, thermoplastic starch (TPS) films have some drawbacks, namely their poor mechanical properties, high water absorption capacity and low water resistance (Du et al., 2008). Different alternatives have been used to improve the properties of starch films, such as blending them with other biopolymers. Starch-gelatin (S-G) based films have been reported to enhance the mechanical resistance and extensibility of starch films (Acosta et al., 2015) and S-G blends have been used to obtain thermo-processed materials for food packaging applications (Moreno et al., 2016). Starch oxidation is a strategy used to increase the hydrophobic nature of starch, since hydroxyl groups in positions $\mathrm{C}-2$ and $\mathrm{C}-3$ of the anhydroglucose units produce dialdehyde starch (DAS) by means of an oxidative cleavage (Yu et al., 2010, Du et al., 2008). It was observed that DAS binds amino groups (e.g. from proteins), producing a more stable crosslinking structure (Wang et al., 2015) and improving the mechanical properties and water resistance of the films due to a reinforced matrix. As DAS is suitable for use in food contact materials and since it was also shown that it can improve the mechanical and barrier properties of starch films, DAS has the potential to be used for packaging applications in the food industry (Martucci and Ruseckaite, 2009). Nevertheless, starch thermo-stability is reduced by oxidation (Soliman et al., 1997), due to the lower thermal stability of the introduced carbonyl groups (Zhang et al., 2007). The thermo-processing of DAS-protein blends can also lead to an extensive browning reaction of polymers at high temperatures via a carbonyl-amino condensation reaction, producing a material that is unsuitable for packaging applications (Martucci and Ruseckaite, 2009). Therefore, for the purposes of crosslinking, carefully controlled conditions (e.g. casting method) can be used to manufacture films using these blends.

Due to their ability for food contact purposes, S-G matrices can be used as carriers of bioactive compounds (e.g. antimicrobials) to manufacture active layers for packaging applications. Active packaging is defined as a type of packaging that changes the condition of the packaging to extend shelf-life or improve safety or sensory properties, while maintaining the quality of the food (Quintavalla and Vicini (2002). Strategies, such 
as the incorporation of a volatile antimicrobial compound into a sachet connected to the package; the direct addition of the active substance into the polymer matrix of the package, the coating of the surface of the packaging material with the active compound carried in an adequate support or the use of antimicrobial macromolecules with film forming ability, have been employed to develop antimicrobial packaging (Coma, 2008). S-G matrices carrying antimicrobial compounds (active layers) are suitable for food contact applications and could exert a controlled release of the antimicrobial towards the food surface.

The application of antimicrobial packaging could be especially interesting for the highly perishable meat products, where microbial contamination occurs primarily at the surface, due to post-processing handling (Quintavalla and Vicini, 2002). Chicken meat is very popular in Europe; however, due to its characteristics (composition, high water activity $\left(\mathrm{a}_{\mathrm{w}}\right)$ and a high $\mathrm{pH}$ ) it is highly perishable (Azlin-Hasim et al., 2015; Rodriguez-Calleja., 2012; Zouaghi and Cantalejo, 2016). Therefore, the poultry industry has shown interest in technologies which can be used to extend the shelf life of chicken breast fillets (Rodriguez-Calleja., 2012).

Ethyl lauroyl arginate (N-a-lauroyl-l-arginine ethyl ester monohydrochloride, LAE), a potent food antimicrobial agent, is considered as GRAS (Generally Recognized As Safe) by the FDA, and in Europe is a food additive (E243) accepted for use in meat products (Hawkins et al., 2009; Higueras et al., 2013). LAE is a cationic surfactant derived from lauric acid, L-arginine, and ethanol that has a wide spectrum of antimicrobial activity (Muriel et al., 2015), even at low concentrations. Higueras et al. (2013) reported a minimally inhibitory concentration (MIC) of 16 and $8 \mu \mathrm{g} / \mathrm{mL}$ for Escherichia coli and Listeria monocytogenes, respectively. It was reported that $L A E$ increases the permeability of the cell membrane, as a consequence of a membrane protein denaturation causing cell growth inhibition or death (Rodriguez et al., 2004). This promising antimicrobial has been successfully applied on chicken (Higueras et al., 2013; Nair et al., 2014); however, to the best of our knowledge, neither the use of S-G matrix as a carrier of this antimicrobial nor the application of the antimicrobial active films as food contact material for the purposes of extending the shelf life of chicken fillets was reported.

The aim of this study was to assess the effectiveness of antimicrobial starch-gelatin films containing LAE at extending the shelf life of chicken breast fillets. Antimicrobial layers were obtained by either the thermoprocessing of non-oxidized starch-gelatin blends or the casting of oxidised starch-gelatin solutions. In both cases, food contact with the films 
was promoted through the vacuum packaging of samples in commercial polyethylene/polyamide laminates.

\section{MATERIALS AND METHODS}

\subsection{Materials}

Film preparation required the following materials: Corn starch (S) (Roquette Laisa España, S.A., Valencia, Spain); Bovine gelatin type A (G) (Sancho de Borja, S.L., Zaragoza, Spain); Sodium periodate (SP) (Fluka Analytical, Sigma-Aldrich Chemie $\mathrm{GmbH}$, Steinheim, Germany); Ethyl lauroyl arginate (LAE) at $10 \% \mathrm{w} / \mathrm{v}$ in ethanol (Vedeqsa, Lamirsa, Terrassa, Spain) and glycerol as plasticizer (Panreac Química S.A., Castellar de Vallès, Barcelona, Spain). Magnesium nitrate for conditioning the pellets was provided by Panreac Química S.A. (Castellar del Vallés, Barcelona, Spain). Conventional vacuum polyamide/low density polyethylene (PA/LDPE) pouches (200x300 $\mathrm{mm}$, water vapour transmission rate of $2.8 \mathrm{~g} / \mathrm{m}^{2} 24 \mathrm{~h}$ and oxygen permeability rate of 50 $\mathrm{cm}^{3} / \mathrm{m}^{2} 24 \mathrm{~h}$ ) were supplied by Cryovac (Sealed AirW.R. Grace Europe Inc., Lausanne, Switzerland) and used as industry standard materials for coating and packaging trials throughout these studies.

The microbiological media used were Maximum Recovery Diluent, Plate Count Agar (PCA), M RS Agar, Brilliance ${ }^{\mathrm{TM}}$ E.coli / Coliform Selective Medium, all of which were supplied by Oxoid (Oxoid Ltd., Basingstoke, England). Tryptic Soy Agar and Yeast extract granulate were supplied by Merck (Merck KGaA, 64271 Darmstadt, Germany).

\subsection{Starch Oxidation}

The corn starch (S) was oxidized following the method described by Wang et al. (2015), using SP as oxidizing agent, but with some modifications. Briefly, a $10 \%(\mathrm{w} / \mathrm{v})$ dispersion of $S$ in distilled water was obtained and gently stirred. SP was added in a molar ratio SP:Glucose unit of 1:1. The dispersion obtained was kept in the dark for four 
hours, under controlled conditions $\left(35^{\circ} \mathrm{C}\right.$ and $\mathrm{pH}$ 3.5). The oxidized starch (OS) was vacuum filtered (Vacuum / Pressure Station, Barnant Company, Barrington, Illinois, United States) and washed three times with distilled water to ensure the complete elimination of the reagent. The oxidised starch was re-dispersed in water at $8000 \mathrm{rpm}$ for 30 seconds using an ultraturrax (DI25, Janke andKunkel, Germany)) and vacuum filtered. The obtained wet solids were used for film preparation, taking into account the water content, previously determined gravimetrically.

\subsection{Film preparation}

\subsubsection{Thermo-processed films}

Two thermo-processed (TP) film formulations were obtained based on a S:G blend (wt. ratio 1:1). To prepare the control formulation (TP_C), the dry components were mixed, and glycerol and water added in a polymer:glycerol:water mass ratio of 1:0.3:1.1. For the antimicrobial active formulation (TP_LAE), LAE was also added, in a polymer: LAE mass ratio of 1:0.1.

To obtain a homogeneous pellet, each formulation was hot-blended at $160^{\circ} \mathrm{C}$ and $8 \mathrm{rpm}$ for 10 minutes on a two-roll mill (Model LRM-M-100, Labtech Engineering, Thailand). Before use, the pellets were conditioned at $53 \%$ relative humidity $(\mathrm{RH})$ for one week at $25{ }^{\circ} \mathrm{C}$ on a desiccator containing an oversaturated solution of $\mathrm{Mg}\left(\mathrm{NO}_{3}\right)_{2}$. The films were obtained by compression moulding using a hot-plate press (Model LP20, Labtech Engineering, Thailand). Four grams of the conditioned pellets paste were pre-heated for $5 \mathrm{~min}$ at $160{ }^{\circ} \mathrm{C}$ in the press plate and then pressed at 30 bar for 2 min and 130 bar pressure for $6 \mathrm{~min}$ at $160{ }^{\circ} \mathrm{C}$. Thereafter, a cooling cycle to $6{ }^{\circ} \mathrm{C}$ was applied for $3 \mathrm{~min}$. The obtained films were $17 \mathrm{~cm}$ in diameter and $180 \pm 0.014 \mu \mathrm{m}$ thick.

\subsubsection{Coated packaging}

Two oxidized starch coating (OC) formulations were obtained. OS (6 \% wt.) was dispersed in distilled water. In order to obtain a total gelatinization of the OS, the dispersion was kept at $99^{\circ} \mathrm{C}$ in a thermostatic water bath (SW23, Julabo $\mathrm{GmbH}, 77960$ Seelbach/ Germany) for $1 \mathrm{~h}$ under gentle agitation at $100 \mathrm{rpm}$. At the same time, a $6 \%$ wt. dispersion of $\mathrm{G}$ was prepared at $40{ }^{\circ} \mathrm{C}$ while being stirred at $450 \mathrm{rpm}$ in a hot-plate for $30 \mathrm{~min}$. Then, both dispersions were cooled down to room temperature and blended in a 
mass ratio OS:G of $1: 1$. For both the control and the active formulation, glycerol was added under constant stirring at a concentration of $25 \% \mathrm{w} / \mathrm{w}$ of the total polymer mass. For the active formulation (OC_LAE), LAE was added in a polymer:LAE ratio of 1:0.1. All of the solutions were kept under constant stirring for $30 \mathrm{~min}$ at $450 \mathrm{rpm}$ until casting. Casting was carried out on a levelled inner polyethylene layer of PA/LDPE laminates using a Micron II film applicator (Gardco, FL, USA) and dried for $48 \mathrm{~h}$ at $20^{\circ} \mathrm{C}$. The solid density obtained on the surface of the PA/LDPE films was $84 \mathrm{~g}$ dry solids $/ \mathrm{dm}^{2}$. To remove unwanted residues at the edges of the coated films, these were cleaned with ethanol. To obtain pouches $(102 \times 177 \mathrm{~mm})$, the edges of the films were heat- sealed using a Henkelman Polar 80 (Henkelman Vacuum System, Model Polar 80, 5221 CK 'sHertogenbosch, The Netherlands) with a sealing time of $2.5 \mathrm{~s}$. In order to avoid adhesion between the coated layers, sterile food grade aluminium foil was placed between them prior to sealing.

\subsection{Chicken supply and sample preparation}

Fresh chicken breast fillets were purchased from a local supplier (Shannon Vale Foods Ltd. Clonakilty, Co. Cork, Ireland). Once received, the chicken was kept in a chill room at $2{ }^{\circ} \mathrm{C}$, and used within $24 \mathrm{~h}$. To avoid cross contamination during sample preparation, all utensils and work surfaces were sanitized with $70 \%$ ethanol. Moreover, before use, the TP and OC films were decontaminated by exposure to UV light for $15 \mathrm{~min}$ in a laminar flow (Airclean 600 PCR Workstation STARLAB, Airclean Systems, USA). Excess fat and cartilage were trimmed from the chicken breast fillets and immediately packaged using either control (TP_C or OC_C) or active films with LAE (TP_LAE or OC_LAE). In the case of the samples packaged with TP films, chicken breast fillets were wrapped in the UV sterilised TP films and placed individually into PA/LDPE pouches. For the chicken breast fillets packaged in the coated PA/LDPE pouches, individual chicken breast fillets were placed into the coated pouches. To maximise contact between the active film layers and the chicken breast fillets, samples were vacuum packed using a Henkelman Polar 80 vacuum system and stored at $4{ }^{\circ} \mathrm{C}$. Three independent experimental series were run for both TP and OC packaged samples. Moreover, fresh chicken samples (3) were vacuum packaged in the conventional PA/LDPE pouches for the initial characterization of the raw material (chicken control). 


\subsection{Physicochemical characterization}

\subsubsection{Proximal analysis}

The proximal composition (fat, moisture, protein and ash) of the control chicken, as well as that of the packaged samples was determined after 2 hours of contact with the packaging.

Fat and moisture contents were determined using the CEM Analysis System (CEM Corporation, Matthews, NC 28105, USA) as described by Bostian et al. (1985). Protein content was determined using the Kjeldahl Method, following AOAC Procedures (1999) (method 981.10). Finally, the ash content was obtained by a gravimetric method; where chicken samples were weighed before and after overnight incineration in a furnace (Nabertherm, Model L9/C6, Nabertherm, Germany) at $550{ }^{\circ} \mathrm{C}$. All the tests were run in duplicate for each series, and the reported values are the average of 6 replicates.

\subsubsection{Determination of $\mathrm{pH}$, lipid oxidation and colour during chilled storage}

Throughout storage, the $\mathrm{pH}$, lipid oxidation and colour changes in the packaged chicken breast fillets were monitored. For Day 0 , the reported values correspond to $2 \mathrm{~h}$ contact with the films. The $\mathrm{pH}$ of the chicken breast fillets was measured using a digital $\mathrm{pH}$ meter by direct insertion of the glass electrode probe into the chicken breast fillet (MettlerToledo $\mathrm{GmbH}$, Schwerzenbach, Switzerland). Four measurements were taken per chicken breast fillet, each value representing the average of 12 replicates.

The lipid oxidation of the chicken breast fillets during chilled storage was assessed using the method described by Siu and Draper (1978).The results were expressed as milligrams of malondialdehyde (MDA) per kilogram of chicken breast fillets, and each value represents the average of 6 replicates (three independent experiments per two samples per two readings)

Once the films were removed, the surface colour of the chicken breast was measured using a portable Minolta CR-300 colorimeter (Minolta Camera Co., Osaka, Japan), previously calibrated with a white ceramic plate $(Y=93.6, x=0.3130, y=0.3193)$. The $\mathrm{CIE} \mathrm{L}^{*}, \mathrm{a}^{*} \mathrm{~b}^{*}$ colour coordinates of the surface of the chicken breast fillets was measured at ten random points on the sample surface. The total colour difference of the packaged samples with respect to the fresh chicken throughout chilled storage was calculated using Equation 5.2.1. The reported value is the average of 30 replicates. 


\subsection{Microbiological analysis}

Microbiological analysis of the packaged chicken breast fillets was carried out at the different storage times. A total of $10 \mathrm{~g}$ of meat sample was aseptically taken from both the upper and bottom surface of the chicken breast fillets using sterile forceps and scalpels, placed into a sterile stomacher filter bag (Seward, UK) to which $90 \mathrm{~mL}$ of sterile Maximum recovery diluent (MRD) (Oxoid, UK) was added and thoroughly mixed for 3 min using a stomacher (Seward, UK) in order to obtain a primary 10-fold dilution. This homogenate was then 10-fold serially diluted using MRD and used to enumerate total viable counts (TVC), psychrotrophic bacteria (PB), Lactic acid bacteria (LAB), anaerobic bacteria (AB), total coliforms (TC) and Escherichia coli (E. coli). TVC and PB were enumerated in PCA plates, after incubation at $37^{\circ} \mathrm{C}$ or $4{ }^{\circ} \mathrm{C}$ for $48 \mathrm{~h}$ or 7 days, respectively. $L A B$ was enumerated using overlaid MRS agar plates after incubation at 30 ${ }^{\circ} \mathrm{C}$ for $72 \mathrm{~h}$. Enumeration of $\mathrm{AB}$ was performed in TSA enriched with $0.6 \%$ yeast extract after $72 \mathrm{~h}$ incubation at $30^{\circ} \mathrm{C}$ under anaerobic conditions in an anaerobic jar containing Anaerocult $\circledast$. Finally, TC and E. coli were enumerated in the chromogenic medium Brilliance E.coli /Coliforms Selective Agar after incubation at $37^{\circ} \mathrm{C}$ for $24 \mathrm{~h}$. The results of bacterial counts were converted to $\log _{10}$ colony-forming units per gram of sample (log CFU/g) prior to statistical analyses.

\subsection{Statistical analysis}

One-way analysis of variance of data was performed using Statgraphics Centurion XVI (Manugistics Corp., Rockville, MD). Fisher's least significant difference (LSD) at the 95 $\%$ confidence level was used to compare treatments. 


\section{RESULTS AND DISCUSSION}

\subsection{Physicochemical characteristics of chicken breasts after two hours of packaging}

\subsubsection{Proximal composition}

All of the chicken samples exhibited a similar initial proximal composition, similar to the values previously reported for these kinds of samples (Azlin-Hasim et al., 2015; Qiao et al., 2002) (Table 5.2.1). The slight variation in the meat composition could be attributed to commercial breeds, diet formulation, housing and general management practices (Quiao et al., 2002). Contact with both TP films significantly decreased the moisture content in the chicken samples compared to control chicken or chicken packaged using both OC films, which can be attributed to the water absorption by the S-G films. Moreno et al (2016) reported a water uptake capacity of $600 \mathrm{~g}$ of water/g dry film for TP_C and TP_LAE formulations, whereas OC_C and OC_LAE films showed a lower water uptake (300 and $100 \mathrm{~g}$ of water/g dry film, respectively). The higher water uptake capacity of the TP films may cause a significant reduction in the moisture content of the chicken samples. As previously reported, the starch oxidation increases the hydrophobicity of the starch matrix, due to the formation of carbonyl and carboxyl groups from hydroxyl groups of non-oxidised chains (Du et al., 2008; Yu et al., 2010,). The increased hydrophobicity of the $\mathrm{OC}$ films reduced their water absorption from the chicken samples, thus better preserving their moisture content (Table 5.2.1). The protein content of samples packaged in TP films significantly $(p<0.05)$ increased with respect to that of the control chicken or chicken packaged in $O C$ films. This increase must be attributed to the significant $(p<0.05)$ reduction in their moisture content by the film's water absorption. 
Table 5.2.1 Composition of the breast samples of both fresh control chicken and after two hours of contact with the packaging. Mean values and statistical deviation. OC, oxidized coating; TP, thermo-processed.

\begin{tabular}{lcccc}
\hline \multicolumn{1}{c}{ Sample } & Moisture \% & Fat \% & Protein \% & Ashes \% \\
\hline Control Chicken & $73.74 \pm 0.04^{\mathrm{b}}$ & $2.59 \pm 0.08^{\mathrm{ab}}$ & $23.7 \pm 0.3^{\mathrm{ab}}$ & $1.26 \pm 0.04^{\mathrm{a}}$ \\
\hline OC_C & $73.5 \pm 0.6^{\mathrm{b}}$ & $2.4 \pm 0.7^{\mathrm{a}}$ & $23.7 \pm 0.3^{\mathrm{a}}$ & $1.24 \pm 0.06^{\mathrm{a}}$ \\
\hline OC_LAE & $73.0 \pm 0.5^{\mathrm{b}}$ & $3.1 \pm 0.3^{\mathrm{b}}$ & $23.4 \pm 0.5^{\mathrm{a}}$ & $1.24 \pm 0.05^{\mathrm{a}}$ \\
\hline TP_C & $72.1 \pm 0.7^{\mathrm{a}}$ & $3.15 \pm 0.10^{\mathrm{b}}$ & $24.9 \pm 1.3^{\mathrm{b}}$ & $1.25 \pm 0.02^{\mathrm{a}}$ \\
\hline TP_LAE & $71.8 \pm 0.9^{\mathrm{a}}$ & $3.2 \pm 0.6^{\mathrm{b}}$ & $24.7 \pm 0.7^{\mathrm{b}}$ & $1.24 \pm 0.03^{\mathrm{a}}$ \\
\hline
\end{tabular}

Different superscripts $(a, b)$ in the same column indicate significant differences between the different formulations.

\subsubsection{Colour, $\mathrm{pH}$ and Lipid oxidation}

Table 5.2.2 shows the colour changes in chicken breast fillets measured after two hours in contact with the different active packaging systems. Significant changes $(p<0.05)$ in the CIE lightness $\left(L^{*}\right)$, redness $\left(a^{*}\right)$ and yellowness $\left(b^{*}\right)$ of the chicken breast fillets packaged using TP films were noticed after two hours in contact. The significant decrease $(p<0.05)$ in the $L^{*}$ values indicated that the chicken breast fillets were darker compared to control samples, which may be attributed to the significant reduction in the moisture content of the chicken breast fillets (section 3.1.1.), which mainly occurred at the surface in contact with the TP film where colour was measured. Water loss lead to changes in the selective light reflection of the sample surface due to the changes in the refractive index of the material and the surface concentration of the pigments (Hutchings, 1999). Thus, the surface moisture loss caused an increase in the darkness of the chicken breast fillets and small changes in the $a^{*}$ and $b^{*}$ values. The migration of the brown compounds from the films, formed during their processing (Moreno et al. 2016), could also slightly affect the chromatic parameters of the fillets. Fletcher et al. (2000) and de Huang et al. (2011) reported $b^{*}$ values of 6.8 for fresh chicken breasts, slightly higher than the obtained $b^{*}$ value; however, genetics has been reported to exert a great influence on the colour of the meat (Lonergan et al., 2003).

After two hours in contact with the active packaging system, the $\mathrm{pH}$ of the chicken breast fillets ranged between 5.86 and 6.16 , which is considered a typical $\mathrm{pH}$ value for poultry meat (Barbut et al., 2005; Economou et al, 2009; Huang et al., 2011; Rodriguez-Calleja et al., 2012; Qiao et al., 2002). Whereas no significant differences in the $\mathrm{pH}$ were noticed for samples packaged using OC-LAE, TP_C or TP-LAE films when compared with the 
control chicken,.samples coated with OC_C films exhibited a significantly $(p<0.05)$ lower $\mathrm{pH}$-value than the control sample,

Lipid oxidation is one of the main factors causing flavour deterioration during the storage of meat and meat products (Azlin-Hasim et al., 2015; Fernández et al., 1997, RodriguezCalleja et al., 2012). This autooxidative degradation generates products which affect food quality; not only the flavour, but also the colour, aroma, texture and nutritive value, even at low temperatures (Eriksson, 1982; Fennema, 1993). The breakage of the initial reaction products obtained from lipid oxidation, mainly hydroperoxides, causes secondary products, such as pentanal, hexanal, 4-hydroxynonenal and malondialdehyde (MDA) (Pearson et al., 1983; Raharjo and Sofos, 1993). Hence, the quantification of MDA by the thiobarbituric acid-reacting substances (TBARS) assay provides an indicator of the secondary oxidation. The analysis of the lipid oxidation of all of the initial samples showed low MDA levels, ranging between 0.05 and $0.33 \mathrm{mg} \mathrm{MDA} / \mathrm{kg}$ of sample, which are typical values for fresh chicken meat (Azlin-Hasim et al., 2015; Chouliara et al., 2007; Rodriguez-Calleja et al., 2012). Significantly $(p<0.05)$ higher TBARS values were obtained in samples packaged in contact with the active films compared to the control samples, with the highest values obtained in samples packaged using the OC coatings.

Table 5.2.2 Values determined for CIE Lab* coordinates ( $L^{*}$, lightness; $a^{*}$, redness; $b^{*}$, yellowness), lipid oxidation expressed as $\mathrm{mg}$ of MDA / $\mathrm{kg}$ of sample, and $\mathrm{pH}$, for fresh chicken and samples after two hours in contact with the different packaging systems. Mean values and statistical deviation.

\begin{tabular}{lccccc}
\hline \multicolumn{1}{c}{ Sample } & $\mathbf{L}^{*}$ & $\mathbf{a}^{*}$ & $\mathbf{b}^{*}$ & $\mathrm{pH}$ & $\begin{array}{c}\text { TBARS } \\
\text { (mg MDA/kg sample) }\end{array}$ \\
\hline Chicken control & $56 \pm 3^{\mathrm{C}}$ & $1.29 \pm 0.14^{\mathrm{a}}$ & $6.4 \pm 1.9^{\mathrm{C}}$ & $6.07 \pm 0.09^{\mathrm{bC}}$ & $0.05 \pm 0.03^{\mathrm{a}}$ \\
\hline OC_C & $55 \pm 2^{\mathrm{bC}}$ & $2.7 \pm 1.3^{\mathrm{C}}$ & $5.3 \pm 1.8^{\mathrm{b}}$ & $5.86 \pm 0.19^{\mathrm{a}}$ & $0.27 \pm 0.06^{\mathrm{cd}}$ \\
\hline OC_LAE & $55 \pm 2^{\mathrm{b}}$ & $1.6 \pm 0.9^{\mathrm{ab}}$ & $5.3 \pm 1.8^{\mathrm{b}}$ & $6.00 \pm 0.17^{\mathrm{b}}$ & $0.33 \pm 0.09^{\mathrm{d}}$ \\
\hline TP_C & $50 \pm 2^{\mathrm{a}}$ & $2.0 \pm 0.6^{\mathrm{b}}$ & $5.7 \pm 1.3^{\mathrm{bC}}$ & $6.10 \pm 0.11^{\mathrm{bc}}$ & $0.17 \pm 0.07^{\mathrm{b}}$ \\
\hline TP_LAE & $50 \pm 2^{\mathrm{a}}$ & $1.8 \pm 1.1^{\mathrm{ab}}$ & $4.4 \pm 1.0^{\mathrm{a}}$ & $6.16 \pm 0.09^{\mathrm{C}}$ & $0.19 \pm 0.12^{\mathrm{bC}}$ \\
\hline
\end{tabular}

Different superscripts $(a, b, c, d)$ in the same column indicate significant differences between the different formulations.

\subsubsection{Microbiological analyses}

The microbial counts determined after two hours in contact with the active packaging systems are shown in Table 5.2.3. The TVC counts of the control chicken $(4.3 \pm 0.3 \mathrm{log}$ 
CFU/g of sample) indicated the good microbiological quality of the chicken meat (AzlinHasim et al., 2015). Similar initial TVC and PB counts were previously reported for these kinds of products (Azlin-Hasim et al., 2015; Balamatsia et al., 2006; Chouliara et al., 2007; Rodriguez-Calleja et al., 2012); although higher LAB counts were obtained in this study. After two hours in contact with the active films, a significant decrease $(p<0.05)$ in the counts of all bacteria, except Coliforms, was noticed for chicken breast fillets packaged in the OC_LAE system. In its turn, E. coli was not detected in these samples. Moreover, chicken breast fillets packaged with the OC_C system showed significantly lower counts of TVC compared to TP_C samples. These results suggest an antimicrobial action of the OC packaging systems, regardless of the presence of $L A E$, which could be related to the presence of antimicrobial compounds formed during film processing. In fact, the carbonyl groups present that are formed in the starch oxidation react with the amino groups of gelatin and/or LAE and form Maillard reaction compounds (Moreno et al. unpublished data). Maillard reaction compounds have been reported to possess antimicrobial activity (Hauser et al., 2014; Wu et al., 2014), attributed to the generation of hydrogen peroxide (Hauser et al., 2014). The greater antimicrobial activity of the OC_LAE films, compared to TP_LAE films, may also be due to the presence of Maillard reaction compounds in these active packaging films and the combined antimicrobial effect with LAE. However, the hydrogen peroxide generated could negatively affect the quality of the food product through the promotion of oxidative processes.

Table 5.2.3 Microbial counts for TVC, PB, LAB, AB, Coliforms and E.coli of the fresh chicken breasts and samples after two hours in contact with the different packaging system. Results expressed as log CFU/g of sample. Mean values and statistical deviation. OC, oxidized coating; TP, thermo-processed.

\begin{tabular}{lcccccc}
\hline \multicolumn{1}{c}{ Sample } & TVC & PB & LAB & AB & Coliforms & E. coli \\
\hline Chicken control & $4.3 \pm 0.3^{\mathrm{b}}$ & $5.10 \pm 0.07^{\mathrm{bc}}$ & $4.2 \pm 0.4^{\mathrm{bC}}$ & $4.6 \pm 0.4^{\mathrm{bc}}$ & $2.0 \pm 0.3^{\mathrm{ab}}$ & $1.49 \pm 0.16^{\mathrm{a}}$ \\
\hline OC_C & $4.2 \pm 0.3^{\mathrm{b}}$ & $5.0 \pm 0.3^{\mathrm{bc}}$ & $4.3 \pm 1.2^{\mathrm{C}}$ & $4.8 \pm 0.8^{\mathrm{C}}$ & $2.7 \pm 0.3^{\mathrm{bc}}$ & $1.6 \pm 0.5^{\mathrm{a}}$ \\
\hline OC_LAE & $3.0 \pm 0.3^{\mathrm{a}}$ & $4.2 \pm 0.6^{\mathrm{a}}$ & $2.3 \pm 1.3^{\mathrm{a}}$ & $3.5 \pm 0.7^{\mathrm{a}}$ & $1.5 \pm 0.5^{\mathrm{a}}$ & $\mathrm{ndg}^{*}$ \\
\hline TP_C & $5.1 \pm 0.5^{\mathrm{C}}$ & $5.5 \pm 0.5^{\mathrm{C}}$ & $4.4 \pm 0.4^{\mathrm{C}}$ & $4.9 \pm 0.3^{\mathrm{C}}$ & $3.0 \pm 0.7^{\mathrm{C}}$ & $2.1 \pm 0.7^{\mathrm{a}}$ \\
\hline TP_LAE & $4.0 \pm 0.9^{\mathrm{b}}$ & $4.7 \pm 0.7^{\mathrm{b}}$ & $3.5 \pm 0.5^{\mathrm{ab}}$ & $4.1 \pm 0.7^{\mathrm{ab}}$ & $2.3 \pm 0.8^{\mathrm{b}}$ & $1.4 \pm 0.3^{\mathrm{a}}$ \\
\hline
\end{tabular}




\subsection{Effect of the packaging system applied on the lipid oxidation, $\mathrm{pH}$ and colour of chicken breast fillets during chilled storage}

\subsubsection{Lipid oxidation}

The changes in lipid oxidation during the chilled storage of the chicken breast fillets are shown in Figure 5.2.1a for the different packaging systems. Chicken breast fillets wrapped inTP films exhibited very slow lipid oxidation throughout storage, whereas samples in contact with OC coated films exhibited a significant $(p<0.05)$ increase in the TBARS values. The significant increase $(p<0.05)$ in the lipid oxidation of chicken samples in OC films, compared to TP films, may be due to the presence of oxidant species formed during the oxidation process of starch with sodium periodate. In fact, Maillard reaction compounds are produced in $\mathrm{OC}$ films due to the carbonyl-amino condensation reaction, and previous studies (Hauser et al., 2014) reported the generation of hydrogen peroxide $\left(\mathrm{H}_{2} \mathrm{O}_{2}\right)$ in line with their antimicrobial action. These oxidant species can also accelerate lipid oxidation in the chicken breast fillets. When packaged in OC_LAE films, samples also underwent significantly greater $(p<0.05)$ lipid oxidation than those in contact with OC_C films, suggesting a greater formation of oxidant compounds when LAE was present in the films. This could be explained by the presence of more reactive amino groups, in line with the greater molecular mobility of this low molecular weight compound (Cárdenas et al., 2016, http://hdl.handle.net/10251/68651).

Melton (1983) reported that a TBARS value of $1.5 \mathrm{mg} \mathrm{MDA} / \mathrm{kg}$ is regarded as the limit beyond which chicken meat will normally develop objectionable odours/tastes. This limit of acceptability in terms of TBARS was reached after 9 storage days in samples packaged in OC_LAE films, while for samples packaged using OC_C films it was reached after nearly 19 days of storage. In contrast, the samples packaged in TP films did not show significant differences in TBARS values, with respect to the fresh chicken, throughout 19 days of chilled storage. 


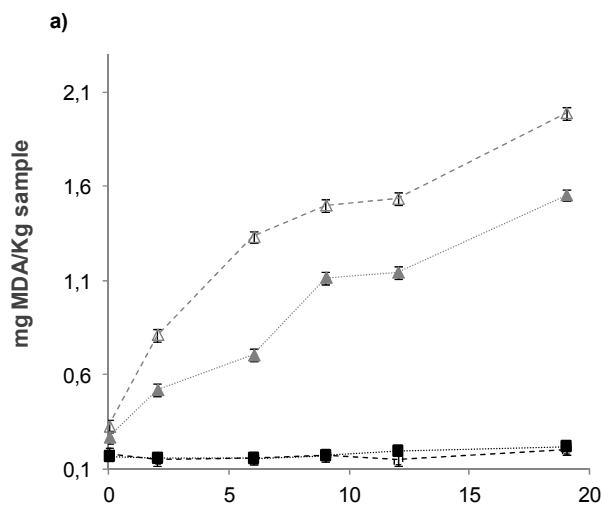

b)

Storage time (days)

Figure 5.2.1 Development of a) TBARS (mg of MDA/g of sample) and b) $\mathrm{pH}$ of the chicken breast samples packaged in thermo-processed films (TP) and oxidized coating films (OC), throughout 19 days at $4{ }^{\circ} \mathrm{C}$. Mean values and $95 \%$ LSD intervals.

\subsection{2. $\mathrm{pH}$ and Colour}

Figure 5.2.1b and Figure 5.2.2 show the changes in the $\mathrm{pH}$ and colour, respectively, for the different packaging systems during chilled storage of the chicken breast fillets in,. The initial $\mathrm{pH}$ values were significantly lower $(\mathrm{p}<0.05)$ in the samples packaged in OC films with and without LAE. These samples exhibited a slow progressive $\mathrm{pH}$ decrease up to day 13; and, after 19 storage days, only samples packaged in OC_LAE films showed a significantly notable $\mathrm{pH}$ decrease $(\mathrm{p}<0.05)$. In contrast, samples packaged in TP films, exhibited a significant decrease $(p<0.05)$ in the $\mathrm{pH}$ up to day 6 of storage, which can be related to the higher counts of $L A B$ found in these samples (section 3.2.3.). The greater production of lactic acid that occurred in line with their higher population provoked a sharper decrease from the initial $\mathrm{pH}$ value of the chicken breast fillets, as previously reported by other authors (Azlin-Hasim et al., 2015; Chouliara et al., 2007). However, after 6 storage days, the $\mathrm{pH}$ increased, which could be caused by the action of PB (higher counts) and the subsequent production of volatile amine and ammonia (CortezVega et al., 2012). The highest $\mathrm{pH}$ values were noticed in samples packaged in LAE-free TP_C films, which also had the highest microbial counts. These results suggest that the development of the $\mathrm{pH}$ of the chicken samples was affected by microbial growth and the oxidation process to a different extent in OC and TP packaged chicken fillets. In samples packaged using $\mathrm{OC}$ films, the $\mathrm{pH}$ was apparently more affected by the progress of the oxidation process, since they had lower microbial counts; in TP systems, however, the sample $\mathrm{pH}$ was mainly governed by the action of bacteria that grow to a greater extent 
(section 3.2.3). Lipid oxidation is also associated with protein oxidation, which increases the number of carboxyl groups and decreases that of sulfhydryl groups, due to the interaction of reactive oxygen species with the proteins (Soyer et al., 2010). Therefore, the significantly $(p<0.05)$ increased oxidation level of chicken breast fillets packed in the OC_LAE system during storage could cause the significant $(p<0.05)$ decrease in the $\mathrm{pH}$ of the chicken meat samples.

The colour of meat is one attribute that greatly influences consumer acceptability of the product (Qiao et al., 2001), since they evaluate the visual appearance of the meat according to their expectations before purchase (Lonergan et al., 2003). Figure 5.2.2 shows the changes in the $L^{*}, a^{*}$ and $b^{*}$ values of chicken breast fillets during chilled storage at $4{ }^{\circ} \mathrm{C}$. $L^{*}$ values of chicken breast fillets increased $(p<0.05)$ when they were packaged in TP or OC packaging systems, indicating that the chicken breast fillets became paler during storage. Previous studies have reported that the $\mathrm{pH}$ significantly influences the lightness of meat products (Barbut et al., 2005; Lonergan et al., 2003; Qiao et al., 2001; Van Laack et al., 2000) and low pH can affect protein solubility and denaturation, leading to a paler meat (Sosnicki, 1995; Pietrzak et al., 1997). Therefore, the $\mathrm{pH}$ changes could provoke the increase in lightness observed in the meat.

Throughout the whole storage period, the redness ( $a^{*}$ values) of chicken breast fillets packaged using both TP and OC films containing LAE was significantly $(p<0.05)$ less marked than that of samples packed in the LAE-free films. This suggests that LAE could interact with the meat pigments, thus affecting its redness. The yellowness ( $b^{*}$ values) of the chicken breast fillets packaged in OC films showed a negative correlation with the $\mathrm{pH}$, since the decrease in $\mathrm{pH}$ took place simultaneously alongside an increase in yellowness. These findings coincide with previous studies carried out on chicken meat (Qiao et al., 2001). The significantly $(p<0.05)$ higher yellowness values obtained at the end of storage in samples packaged in OC_LAE films (Figure 5.2.2c) may be related with the higher oxidation levels observed in these samples and their lower $\mathrm{pH}$ (Figure 5.2.1). Figure 5.2.2d shows the total colour difference quantified for the packaged samples throughout chilled storage at $4^{\circ} \mathrm{C}$ with respect to the initial fresh chicken. $\mathrm{A} \Delta \mathrm{E}$ value of 1.5 was quantified between the different fresh samples, at the limit of the visual colour difference perception ( $\Delta \mathrm{E} \sim 1$ in the $C I E L^{*} a^{*} b^{*}$ space (Hutchings, 1999)). Most of the packaged samples exhibited colour differences with respect to fresh chicken of under 5 , which correspond to a reasonable tolerance as regards the colour difference in food products (Bodart et al., 2008). The samples that were newly packaged in TP systems showed greater $\Delta \mathrm{E}$ values due to their surface dehydration, as commented on above, 
but this difference was mitigated throughout storage in line with the progressive water diffusion from the inner part of the breast. After 19 storage days, the samples packaged in the OC_LAE system also exceeded $5 \Delta \mathrm{E}$ units, which is attributable to the great oxidation progress and the $\mathrm{pH}$ - associated change. Therefore, only samples packaged in the OC_LAE system exhibited an unacceptable colour change after 19 storage days, but they also presented excessive oxidation levels.

a)

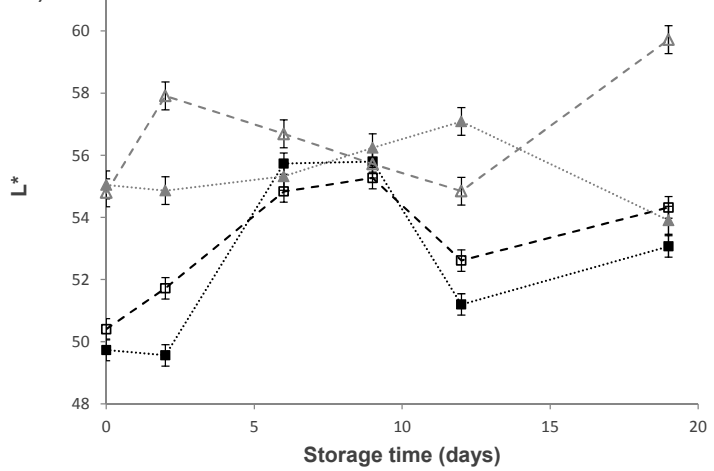

c)

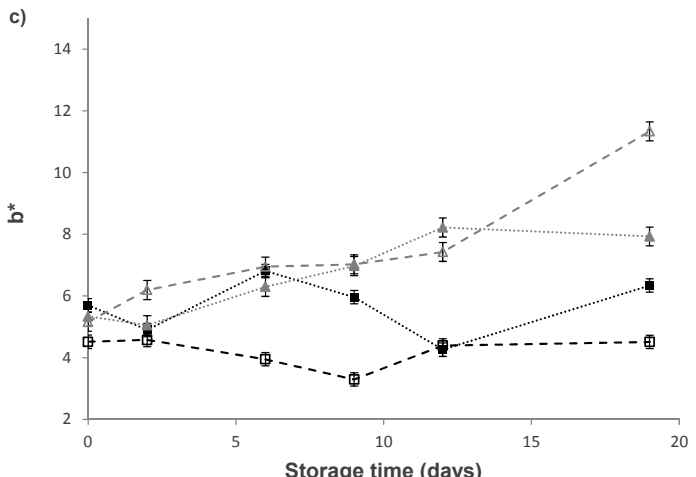

b)

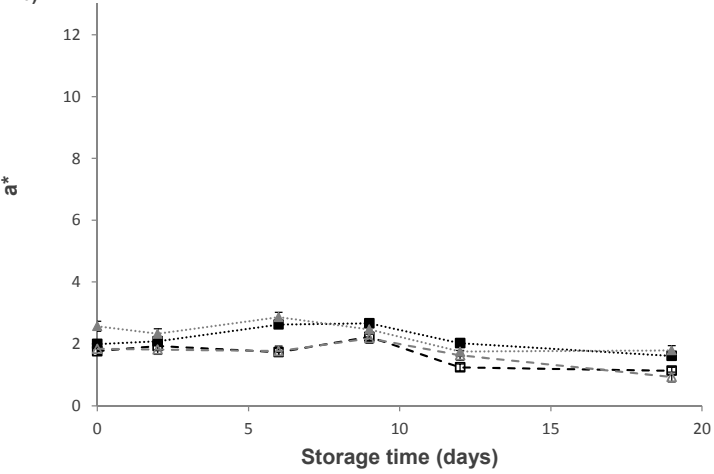

d)

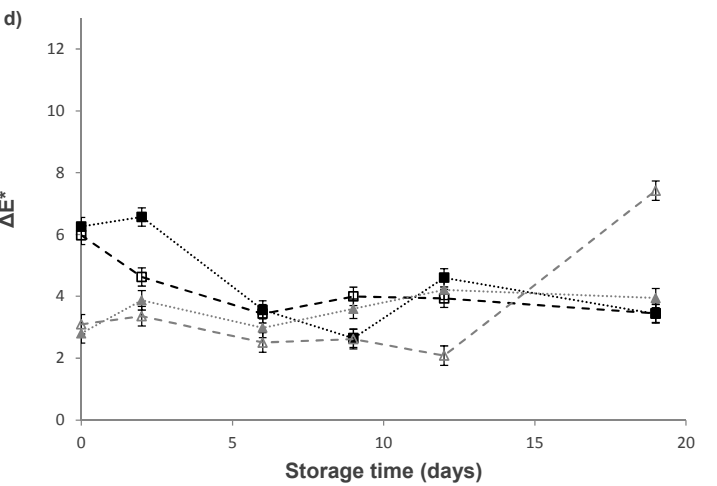

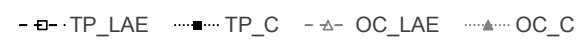

Figure 5.2.2 Development of the colour coordinates: a) $L^{*}$, lightness; b) $a^{*}$, redness; c)

$b^{*}$, yellowness and d) total colour difference, $\Delta \mathrm{E}^{*}$ of the chicken breast samples packaged in thermo-processed films (TP) and oxidized coating films (OC), throughout 19 days at $4{ }^{\circ} \mathrm{C}$. Mean values and $95 \%$ LSD intervals. 


\subsubsection{Microbial growth}

The microbial quality of poultry meat is used as an indicator of freshness (Balamatsia et al., 2006), since the growth of spoilage microorganisms can cause the development of unacceptable off-odours and off-flavours (Zhao et al., 1994; Davies, 1995). Chouliara and Kontominas (2006) set out the useful application of natural food preservatives to enhance protection against not only spoilage, but also against pathogenic microorganisms. The following recommended limits of acceptability are applied for raw chicken: Aerobic plate counts: $m=10^{6}$ (CFU/g of chicken meat) (acceptable limit) and $\mathrm{M}$ $=10^{7}$ (CFU/g of chicken meat) (Unacceptable limit) (ICMFS, 1990). Thus, in this study, a marginal value of 6 log CFU/g of chicken meat for TVC was set as the maximum limit of acceptability.

Changes in the microbiological counts of TVC, PB, LAB, AB and the total coliforms of chicken breast fillets in the different packaging systems during chilled storage are shown in Figure 5.2.3. Generally, the microbial count of all bacteria increased during storage time, and chicken samples packaged using films containing LAE (TP_LAE or OC_LAE) exhibited a delayed growth of bacteria compared to control films. However, lower bacterial counts were noticed in samples packaged in OC films when compared to those in TP films. The differences in the bacterial load may be due to the presence of Maillard compounds formed during the film processing; these possess antimicrobial activity, as previously commented on (section 3.1.3.). Greater effects were noticed in TVC and LAB for samples packaged in OC_C films compared to samples in contact with TP_C films. Similarly, OC_LAE films were more effective than TP_LAE films at delaying the growth of most bacteria, which also points to a combined effect of LAE and the Maillard compounds developed in the $\mathrm{OC}$ films. An in vitro test study revealed that $\mathrm{OC}$ film formulations with and without LAE exhibited antimicrobial activity against $L$. innocua (CECT 910) (data not shown), which was attributed to these Maillard compounds, whose antimicrobial activity was attributed to their capacity to generate hydrogen peroxide (Hauser et al., 2014). Due to its oxidant capacity, a higher degree of oxidation was also observed when $\mathrm{OC}$ films were used to package the chicken breast fillets (section 3.2.1.).

As commented on above (section 3.2.2.), the changes in the $\mathrm{pH}$ of samples packaged in TP films were closely related to the microbial growth (Figure 5.2.1b). The significant $(p<0.05)$ decrease in the $\mathrm{pH}$ between days 2 and 6 in the case of fillets packaged in TP films can be related to the growth of LAB and the production of lactic acid (Azlin-Hasim et al., 2015; Chouliara et al., 2007). Likewise, the subsequent increase in the $\mathrm{pH}$ may be related to the higher PB counts and the production of volatile amine and ammonia 
(Cortez-Vega et al., 2012). These changes were more noticeable in samples packaged using TP_C films, which also showed the highest microbial counts.
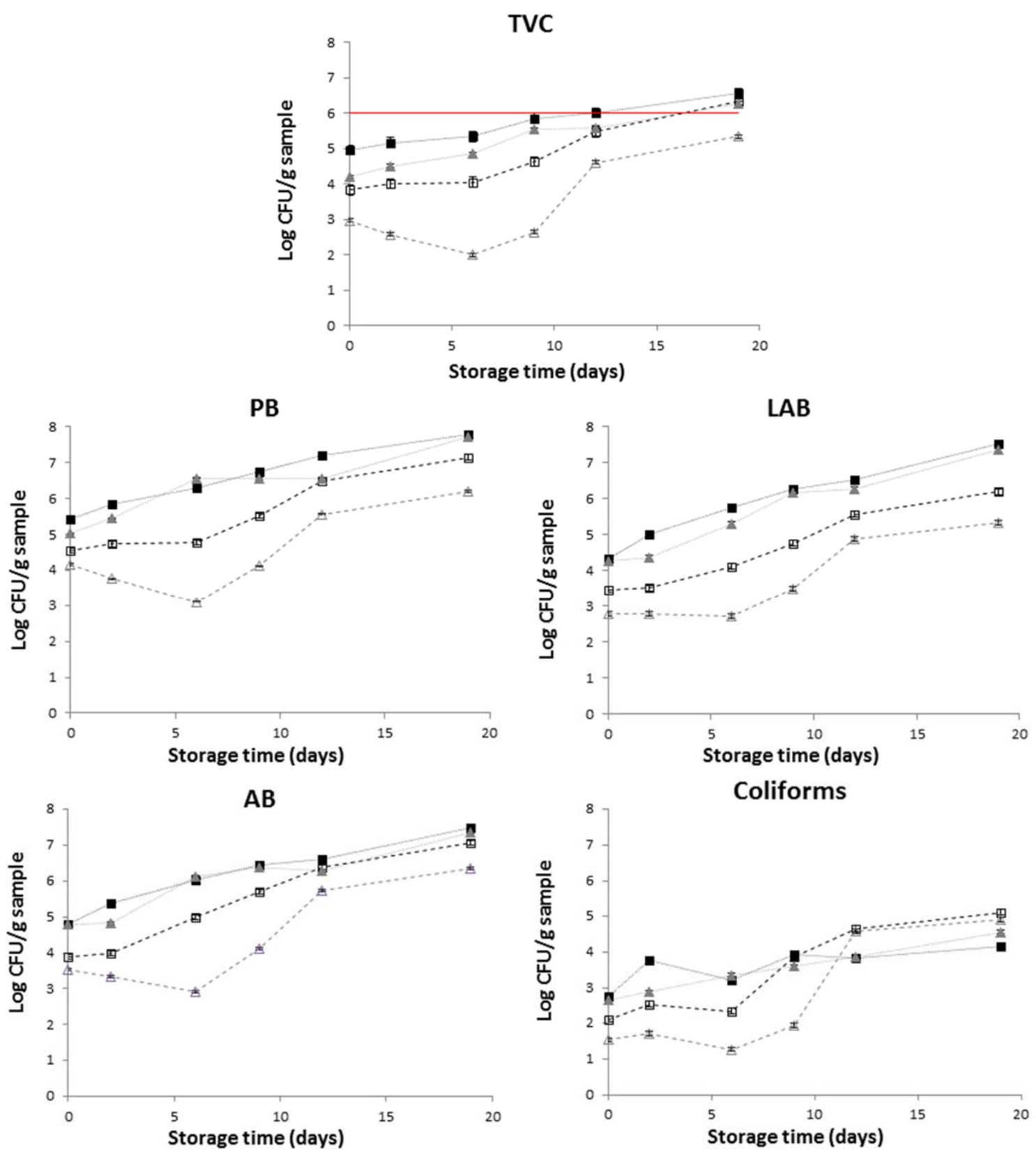

- ש- TP_LAE

- TP_C Dead line

$\cdots$ OC_LAE

$\triangle O C \_C$

Figure 5.2.3 Mean values (and 95 \% LSD intervals) of microbial counts obtained for the chicken breast samples packaged in thermo-processed (TP) films and oxidized coating (OC) films, throughout 19 days at $4{ }^{\circ} \mathrm{C}$. 
In terms of microbial growth, the use of films containing LAE significantly extended the shelf life of chicken breast filets, when compared to control films. The limit of microbial acceptability (6 log CFU/g of chicken) for TVC was reached after day 12 for samples packaged in TP_C films; however, this limit was reached after day 16 when fillets were packaged in TP_LAE or OC_C films and it was not reached throughout the 19 storage days in the case of the fillets in contact with OC_LAE films. However, for chicken samples packaged in OC_LAE, the limiting factor for shelf life was lipid oxidation instead of microbiological acceptability (section 3.2.1). As previously stated (section 3.1.3), OC films exhibited antimicrobial activity in chicken samples regardless of the LAE presence; nevertheless, this was enhanced by the incorporation of this compound and it is remarkable that the incorporating LAE to the films had a greater antimicrobial effect in OC films than in TP films due to the combined action of active compounds.

Regardless of the active packaging system used, the PB counts were the highest and so, PB were the main spoilage microorganism. It was reported that chilled storage conditions $\left(4^{\circ} \mathrm{C}\right)$ can enhance the growth of psychrotrophic bacteria compared to mesophilic bacteria (TVC) (Murphy et al., 2013). The spoilage rate of chicken is influenced, among other things, by the initial number and type of bacteria present and their subsequent growth during product storage which, in turn, depends on the combined effect of the treatment and other factors, such as storage temperature, $\mathrm{pH}$ and packaging environment (Rodriguez-Calleja et al., 2012).

$L A B$, as anaerobic facultative bacteria, are able to grow in the presence or absence of $\mathrm{O}_{2}$ (Azlin-Hasim et al., 2015). As reported in section 3.1.3, the initial LAB counts were higher than the TVC counts. However, both antimicrobial packaged films (TP_LAE and $\left.O C \_L A E\right)$ delayed the growth of $L A B$. Likewise, during storage, the lowest $A B$ counts were obtained in samples packaged in TP_LAE or OC_LAE systems, these counts being significantly lower in samples packaged in OC-LAE films. The change in the internal environment at a low $\mathrm{O}_{2}$ concentration may have favoured the growth of $A B$, since one of the factors that affects the flora of chicken is the packaging system used (RodriguezCalleja et al., 2012).

The coliform count was also significantly $(p<0.05)$ affected by the packaging system. In the first period, chicken breast fillets packaged using TP or OC films containing LAE had the lowest total coliform counts. However, the growth resumed after day 6 in samples packaged in all of the films containing LAE. This behaviour may be due to the partial recovery and growth of the bacteria in response to the stress induced by the antimicrobial compound increasing their viability and resuming growth during storage. 
Regardless of the packaging system, the initial counts of $E$. coli were below the detection limit ( $<1 \log$ CFU/g) (data not shown) and a slight increase in the E. coli counts was noticed during the storage period in samples packaged in the LAE free films, reaching a level of $2.1 \mathrm{log}$ CFU/g at the end of storage. Antimicrobial TP_LAE or OC_LAE films were effective at maintaining the numerical presence of $E$. coli below the detection limit, indicating the effectiveness of LAE as an antimicrobial with which to preserve chicken breast fillets.

The obtained results indicated that $L A B$, Gram positive bacteria, were more sensitive to the antimicrobial action of LAE than total coliforms, Gram negative bacteria, which offer greater resistance to the antimicrobial action of LAE. This agrees with previous studies which reported a more intense antimicrobial activity of LAE against Gram positive bacteria than against Gram negative (Higueras et al., 2013; Ma et al., 2013; Muriel-Galet et al., 2012). 


\section{CONCLUSIONS}

ilms of S-G containing LAE greatly enhanced the shelf life of chicken breast

fillets. The microbiological limit of acceptability for TVC was reached after 16 or

12 days of storage when chicken breast fillets were packaged in TP films containing or not LAE, respectively. This represented a notable increase (4 days) in the shelf life of chicken breast fillets compared to samples packaged in non-active films (TP_C). Those films containing oxidised starch (OC) without LAE also exhibited antimicrobial activity, extending the shelf life of the fillets by 4 days when compared to non-active TP_C films. Nevertheless, OC_LAE films were the most effective at controlling microbial growth (the microbial limit was not reached during the 19 storage days), but the presence of pro-oxidant compounds in OC films promoted lipid oxidation, which, in turn, affected the colour of the samples. Therefore, in samples packaged in OC films, the critical parameter to define the shelf life of the chicken breast fillets was the oxidation level. The limit of acceptability of $1.5 \mathrm{mg} \mathrm{MDA} / \mathrm{kg}$ was reached after 9 days of storage. So, despite the greater antimicrobial effectiveness of OC films, this material is not recommended as packaging material for the purposes of preserving oxidationsensitive foodstuffs. Overall, starch-gelatin TP films containing LAE have the potential to be used as antimicrobial packaging material in order to increase the shelf life of chicken breast fillets significantly during chilled storage.

\section{Acknowledgements}

The authors acknowledge the financial support provided by Ministerio de Economía y Competividad (Projects AGL2016-76699-R and AGL2013-42989-R). Olga Moreno Marro also thanks the Ministerio de Educación, Cultura y Deporte for the FPU 2012-1121 grant. 


\section{REFERENCES}

Acosta, S., Jiménez, A., Cháfer, M., González-Martínez, C., Chiralt, A. (2015) Physical properties and stability of starch-gelatin based films as affected by the addition of esters of fatty acids. Food Hydrocolloids, 49, 135-143.

Azlin-Hasim, S., Cruz-Romero, M. C., Morris, M. A., Cummins, E., \& Kerry, J. P. (2015). Effects of a combination of antimicrobial silver low density polyethylene nanocomposite films and modified atmosphere packaging on the shelf life of chicken breast fillets. Food Packaging and Shelf Life, 4, 26-35.

Balamatsia, C. C., Paleologos, E. K., Kontominas, M. G., \& Savvaidis, I. N. (2006). Correlation between microbial flora, sensory changes and biogenic amines formation in fresh chicken meat stored aerobically or under modified atmosphere packaging at $4 \mathrm{C}$ : possible role of biogenic amines as spoilage indicators. Antonie van Leeuwenhoek, 89(1), 9-17.

Barbut, S., L. Zhang, \& M. Marcone. (2005). Effects of pale, normal, and dark chicken breast meat on microstructure, extractable proteins, and cooking of marinated fillets. Poultry Science, 84:797-802.

Bodart, M., De Penaranda, R., Deneyer, A. \&Flamant, G. (2008). Photometry and colorimetry characterisation of materials in daylightin evaluation tolos. Building and Environment, 43 (12), 2046-2058.

Bostian, M. L., Fish, D. L., Webb, N. B., \& Arey, J. J. (1985). Automated methods for determination of fat and moisture in meat and poultry products: Collaborative study. Journal of the Association of Official Analytical Chemists, 68(5), 876-880.

Cárdenas Estela, J. (2016). Films biodegradables activos de almidón-gelatina. Efecto de la oxidación del almidón. http://hdl.handle.net/10251/68651.

Cazón, P., Velazquez, G., Ramírez, J. A., \& Vázquez, M. (2016). Polysaccharide-based films and coatings for food packaging: A review. Food Hydrocolloids.

Chouliara, E., Kontominas, M. G., Singh, V. K., Govil, J. N., Ahmad, K., \& Sharma, R. K. (2007). Combined effect of thyme essential oil and modified atmosphere packaging to extend shelf-life of fresh chicken meat. Natural products I, 423-441.

Chouliara, E., Karatapanis, A., Savvaidis, I. N., \& Kontominas, M. G. (2007). Combined effect of oregano essential oil and modified atmosphere packaging on shelf-life extension of fresh chicken breast meat, stored at 4 C. Food Microbiology, 24(6), 607-617.

Coma, V., (2008). Bioactive packaging technologies for extended shelf life of meatbased products. Meat science, 78(1), 90-103. 
Cortez-Vega, W. R., Pizato, S., \& Prentice, C. (2012). Quality of raw chicken breast stored at $58 \mathrm{C}$ and packaged under different modified atmospheres. Journal of Food Safety, 32(3), 360-368.

Davies, A.P., 1995. Advances of MAP. In: Gould, G.W. (Ed.), Natural antimicrobial systems and Food Preservation. Blackie, Glasgow, pp. 304-320.

Dawson, P.L., Hon, H., Vollet, L.M., Clardy, L.B., Martinez, R.M., Acton, J.C., 1995. Film oxygen transmission rate effects on ground chicken meat quality. Poultry Science, 14, $1381-1387$.

Du, Y. L., Cao, Y., Lu, F., Li, F., Cao, Y., Wang, X. L., \& Wang, Y. Z. (2008). Biodegradation behaviors of thermoplastic starch (TPS) and thermoplastic dialdehyde starch (TPDAS) under controlled composting conditions. Polymer Testing, 27(8), 924930.

EC (2007). Commission Regulation No 1441/2007 of 5 December 2007 amending Regulation (EC) No 2073/2005 on microbiological criteria for foodstuffs.

Economou, T., Pournis, N., Ntzimani, A., \& Savvaidis, I. N. (2009). Nisin-EDTA treatments and modified atmosphere packaging to increase fresh chicken meat shelf-life. Food Chemistry, 114(4), 1470-1476.

Eriksson, C. E. (1982). Lipid oxidation catalysts and inhibitors in raw materials and processed foods. Food Chemistry., 9, 3-9.

Fennema, 0. R. (1993). Química de los alimentos. Ed. Acribia, Zaragoza, Spain.

Fernández, J., Pérez-Álvarez, J. A., \& Fernández-López, J. A. (1997). Thiobarbituric acid test for monitoring lipid oxidation in meat. Food Chemistry, 59(3), 345-353.

Fletcher, D. L., M. Qiao, and D. P. Smith. 2000. The relationship of raw broiler breast meat color and $\mathrm{pH}$ to cooked meat color and $\mathrm{pH}$. Poultry Science, 79:784-788.

Hauser C., Müller U., Sauer T., Augner K., Pischetsrieder. (2014). Maillard reaction products as antimicrobial components for packaging films. Food chemistry, 145, 603613.

Hawkins, D.R., Rocabayera, X., Ruckman, S., Segret, R., Shaw, D. (2009). Metabolism and pharmacokinetics of ethyl Na-lauroyl-L-arginate hydrochloride in human volunteers. Food and Chemical Toxicology, 47, 2711-2715.

Higueras, L., López-Carballo, G., Hernández-Muñoz, P., Gavara, R., Rollini, M. (2013) Development of a novel antimicrobial film based on chitosan with LAE (ethyl-Nadodecanoyl-L-arginate) and its application to fresh chicken. International Journal of Food Microbiology, 165, 339-345.

Huang, H., Williams, S. K., Sims, C. A., \& Simmone, A. (2011). Sodium metasilicate affects antimicrobial, sensory, physical, and chemical characteristics of fresh commercial chicken breast meat stored at $4 \mathrm{C}$ for 9 days. Poultry science, 90(5), 1124-1133. 
Hutchings, J. B. (1999). Instrumental specification. In Food colour and appearance (199237 pp). Springer US.

Jiménez, A., Fabra, M. J., Talens, P., \& Chiralt, A. (2012). Edible and biodegradable starch films: a review. Food and Bioprocess Technology, 5(6), 2058-2076.

Lonergan, S. M., Deeb, N., Fedler, C. A., \& Lamont, S. J. (2003). Breast meat quality and composition in unique chicken populations. Poultry Science, 82(12), 1990-1994.

Malathi, A. N., Santhosh, K. S., \& Nidoni, U. (2014). Recent trends of biodegradable polymer: biodegradable films for food packaging and application of nanotechnology in biodegradable food packaging. Current Trends in Technology and Science, 3(2), 73-79.

Martucci, J. F., \& Ruseckaite, R. A. (2009). Tensile properties, barrier properties, and biodegradation in soil of compression-Molded gelatin-dialdehyde starch films. Journal of Applied Polymer Science, 112(4), 2166-2178.

Melton, S. L. (1983). Methodology for following lipid oxidation in muscle foods. Food Technology., 37, 105-I 11.

Moreno, O., Pastor, C., Muller, J., Atarés, L., González, C., Chiralt, A. (2014). Physical and bioactive properties of corn starch - Buttermilk edible films. Journal of Food Engineering, 141, 27-36.

Moreno, O., Díaz, R., Atarés, L., \& Chiralt, A. (2016). Influence of the processing method and antimicrobial agents on properties of starch-gelatin biodegradable films. Polymer International.

Muriel-Galet, V., López-Carballo, G., Gavara, R., Hernández-Muñoz, P. (2015) Antimicrobial Effectiveness of Lauroyl Arginate Incorporated into Ethylene Vinyl Alcohol Copolymers to Extend the Shelf-Life of Chicken Stock and Surimi Sticks. Food Bioprocess Technol, 8, 208-217.

Mrkić, S., Galić, K., Ivanković, M., Hamin, S., \& Ciković, N. (2006). Gas transport and thermal characterization of mono-and di-polyethylene films used for food packaging. Journal of applied polymer science, 99(4), 1590-1599.

Murphy, K. M., O'Grady, M. N., \& Kerry, J. P. (2013). Effect of varying the gas headspace to meat ratio on the quality and shelf-life of beef steaks packaged in high oxygen modified atmosphere packs. Meat Science, 94(4), 447-454.

Nair, D. V., Nannapaneni, R., Kiess, A., Mahmoud, B., \& Sharma, C. S. (2014). Antimicrobial efficacy of lauric arginate against Campylobacter jejuni and spoilage organisms on chicken breast fillets. Poultry science, 93(10), 2636-2640.

Pearson, A. M., Gray, J. I., Wolzak, A. M. \& Horenstein, N. A. (1983). Safety implications of oxidized lipids in muscle foods. Food Technology., 37, 121-129.

Pietrzak, M., Greaser, M. L., \& Sosnicki, A. A. (1997). Effect of rapid rigor mortis processes on protein functionality in pectoralis major muscle of domestic turkeys. Journal of Animal Science, 75(8), 2106-2116. 
Qiao, M., D. L. Fletcher, D. P. Smith, and J. K. Northcutt, (2001). The effect of broiler breast meat color on $\mathrm{pH}$, moisture, waterholding capacity, and emulsification capacity. Poultry Science, 80:676-680.

Qiao, M., Fletcher, D. L., Northcutt, J. K., \& Smith, D. P. (2002). The relationship between raw broiler breast meat color and composition. Poultry Science, 81(3), 422-427.

Quintavalla, S., \& Vicini, L. (2002). Antimicrobial food packaging in meat industry. Meat science, 62(3), 373-380.

Raharjo, S. \& Sofos, J. N. (1993). Methodology for measuring malonaldehyde as a product of lipid peroxidation in muscle tissues: A review. Meat Science, 35, 145-169.

Rodríguez, E., Seguer, J., Rocabayera, X., Manresa., A. (2004) Cellular effects of monohydrochloride of L-arginine, Na-lauroyl ethylester (LAE) on exposure to Salmonella typhimurium and Staphylococcus aureus. Journal of Applied Microbiology. 96, 903-912.

Rodríguez-Calleja, J. M., Cruz-Romero, M. C., O’Sullivan, M. G., García-López, M. L., \& Kerry, J. P. (2012). High-pressure-based hurdle strategy to extend the shelf-life of fresh chicken breast fillets. Food Control, 25(2), 516-524.

Siracusa, V., Rocculi, P., Romani, S., \& Dalla Rosa, M. (2008). Biodegradable polymers for food packaging: a review. Trends in Food Science \& Technology, 19(12), 634-643.

Siu, G. M., \& Draper, H. H. (1978). A survey of malonaldehyde content of retail meats and fish. Journal of Food Science, 43, 1147-1149.

Soliman, A. A., El-Shinnawy, N. A., \& Mobarak, F. (1997). Thermal behaviour of starch and oxidized starch. Thermochimica Acta, 296(1), 149-153.

Sosnicki, A. A. (1995). The domestic turkey: a model of the impact of selection and production practices on meat quality. Expression of tissue proteinases and regulation of protein degradation as related to meat quality. A. Ouali, DI Demeyer, and FJM Smulders, ed. Audet Tijdschriften BV, Nijmegen, The Netherlands, 363-380.

Soyer, A., Özalp, B., Dalmış, Ü., \& Bilgin, V. (2010). Effects of freezing temperature and duration of frozen storage on lipid and protein oxidation in chicken meat. Food chemistry, 120(4), 1025-1030.

Van Laack, R. L. J. M., Liu, C. H., Smith, M. O., \& Loveday, H. D. (2000). Characteristics of pale, soft, exudative broiler breast meat. Poultry Science, 79(7), 1057-1061.

Wang, X., Gu, Z., Qin, H., Li, L., Yang, X., \& Yu, X. (2015). Crosslinking effect of dialdehyde starch (DAS) on decellularized porcine aortas for tissue engineering. International journal of biological macromolecules, 79, 813-821.

Wu Shuping., Hu Jiao., Wei Liuting., Du Y., Shi X., Zhang L. (2014). Antioxidant and antimicrobial activity of Maillard reaction products fron xylan with chitosan/chitooligomer/glucosamine hydrochloride/taurine model systems. Food Chemistry 143, 148-203 
Yu, J., Chang, P. R., \& Ma, X. (2010). The preparation and properties of dialdehyde starch and thermoplastic dialdehyde starch. Carbohydrate Polymers, 79(2), 296-300.

Zhang, S. D., Zhang, Y. R., Zhu, J., Wang, X. L., Yang, K. K., \& Wang, Y. Z. (2007). Modified corn starches with improved comprehensive properties for preparing thermoplastics. Starch-Stärke, 59(6), 258-268.

Zhao, Y., Wells, J. H., \& McMILLIN, K. W. (1994). Applications of dynamic modified atmosphere packaging systems for fresh red meats: review. Journal of Muscle Foods, 5(3), 299-328.

Zouaghi, F., \& Cantalejo, M. J. (2016). Study of modified atmosphere packaging on the quality of ozonated freeze-dried chicken meat. Meat science, 119, 123-131. 


\section{GENERAL DISCUSSION}

$\mathrm{n}$ order to obtain starch-based (S) biodegradable active packaging materials with improved properties or antimicrobial capacity, different blends with protein materials have been studied, namely buttermilk (BM); enzymes, such as lysozyme (LZ) and lactoferrin (LF) and their blends, and bovine gelatin (BG). Additionally, the incorporation of ethyl lauroyl arginate (LAE), as antimicrobial agent, was also studied. Films were obtained by applying two different methodologies, wet process (casting) and melt blending and compression moulding as dry process. On the other hand, the oxidation of $S$ was also studied, prior to its blend with $B G$ and the incorporation of $L A E$, aiming to reinforce the crosslinking between polymer chains and to improve the films' functional properties. All of the different approaches were also intended to minimize the highly hygroscopic nature of $S$ films and their retrogradation throughout storage time. Therefore, the films were characterized as to their main functional properties as packaging material, as well as to their antioxidant and/or antimicrobial properties. The food preservation capacity of the materials obtained using the different blend strategies, in terms of the lipid oxidation and microbiological spoilage of several food systems, was also studied.

Although proteins are also hydrophilic polymers, no total compatibility with $S$ was observed in the different blends, and both the kind of protein and its ratio in the film affected the structural homogeneity of the materials, which greatly affected the physical properties and thermal behaviour of the films. Despite the high content in whey protein, BM also contains low molecular weight compounds, such as lactose, and salts, which had a plasticizing effect in the films. Its incorporation resulted in a heterogeneous structure causing the weakening of the matrix, due to the presence of discontinuities and interruptions in the $S$ network. This led to a reduction in not only the stiffness and resistance to break of the films, but also in their barrier ability against water vapour and transparency; these effects were more marked when the BM ratio increased in the films. However, the polymer homogenization under heating when using the film with the highest BM proportion ( $60 \mathrm{wt}$. \%) resulted in the formation of a gel during the film drying step, which increased its compatibility and reinforced the polymeric matrix, thus 
enhancing the functional properties of the film when compared with films with no thermally treated BM.

As concerns the blends with LF and/or LZ, both proteins showed a better, although still partial, compatibility with $\mathrm{S}$, when compared with BM. Their incorporation in relatively low proportions (10 and $20 \%$ wt.) showed a lack of complete polymer miscibility, the film structure exhibiting discontinuities and globular formations at the surface, due to the phase separation and creaming of the protein phase. As occurred in starch BM blend films, the incorporation of LF and LZ implied an increase in the films' brittleness with a notable decrease in their stretchability and transparency. This trend was more evident for films containing LF, which showed poorer mechanical behaviour, regardless of the films' water content. Nonetheless, both proteins showed partial compatibility with $\mathrm{S}$, which led to the formation of starch-protein aggregates, increasing the mean molecular weight and, thus, the glass transition temperature $(\mathrm{Tg})$ of the amorphous phase of the films. StarchLZ interactions occurred to a greater extent, leading to higher Tg values. Nevertheless, both proteins provoked a decrease in the initial $\left(T_{0}\right)$ and the maximum degradation rate ( $\left.T_{\max }\right)$ temperatures. Barrier properties were improved subsequent to the addition of proteins; this was firstly due to the partial complexation that limited the mass transfer processes, in agreement with the $\mathrm{Tg}$ increase, and secondly, to the protein-rich layer formed on the film's surface throughout the drying step.

The blend films of $S$ with BG (mass ratio 1:1), also exhibited phase separation, which was mitigated by the addition of LAE addition to the films. In films obtained by casting, a BG-rich phase was located at the top, while the higher density S-rich phase was located at the bottom, in agreement with the stratification also observed when LF and/or LZ were incorporated. The BG blend with $S$ greatly increased the elongation of the films without affecting their resistance, due to the high degree of cohesion between each homopolymer chain. However, a slight decrease in the films' stiffness was observed as a result of the BG incorporation. In addition, the fact that BG was more compatible than the previously tested proteins also implied a huge reduction in WVP, to a greater extent than that observed for LF and/or LZ incorporation.

On the other hand, the films' preparation method seriously affected the interactions between $S$ and $B G$ chains, influencing the microstructure of the films and their main functional properties. In films obtained by casting, the unfolded chains of polymers in water solution interact during the drying step, leading to a partial phase separation and stratification according to their respective density, thus resulting in two independent networks with strong chain attraction within each homopolymer phase. In addition, the 
organization and mobility of starch chains throughout the drying step enables the crystallization process. In contrast, thermoprocessed films had different polymer domains with less opportunity for molecular interaction and weaker interface adhesion between the different domains, exhibiting a more amorphous structure. Consequently, cast films had a stronger structure, leading to greater stiffness and resistance, better water vapour and oxygen barrier properties and higher transparency. On the other hand, the thermal treatment of the polymer blend enabled a carbonyl-amino condensation reaction between starch and $\mathrm{BG}$, thus decreasing both the content of $-\mathrm{OH}$ and the water binding capacity of the films. Consequently, thermoprocessed films showed a notably lower water uptake capacity, and the reactions that occurred during the melt blending process led to the browning of the films. Nonetheless, thermoprocessed films were the only ones which showed overall migration values under the legal limit established by the current law $\left(10 \mathrm{mg} / \mathrm{dm}^{2}\right)$ referring to the hydrophobic food simulant, isooctane, whereas their lower structural cohesiveness led to higher overall migration values in hydrophilic simulants.

The incorporation of $L Z$ and $L A E$ as antimicrobial agents had different effects on the functional properties of the S-BG films depending on the film processing method. Due to their amphiphilic nature, both LZ and LAE enhanced the blending capacity between polymers, which was much more noticeable when LAE was applied, giving rise to smaller domains in the thermoprocessed films and increasing both the interfacial adhesion and the overall hydrophobicity of the films. Its incorporation also seemed to exert a thermo-protective effect during the melt blending process. $L Z$ addition mitigated the stratification phenomenon in cast films, while increasing the water binding capacity of the films. The different effects of both agents were also appreciable in the case of barrier properties. LZ incorporation led to a decrease in OP and an increase in WVP, while LAE provoked the opposite behaviour.

Starch oxidation treatment also affected the functional properties of the films. Specifically, the oxidation process led to the obtaining of dialdehyde starch (DAS), with a decrease in $-\mathrm{OH}$ groups and an increase in $\mathrm{C}=\mathrm{O}$. The condensation reaction between these carbonyl and amino groups from BG enhanced the compatibility between polymers through the crosslinking of the chains. As a consequence, a more hydrophobic and homogeneous structure was obtained, with greater integration and no phase separation. The complete oxidation of the starch led, thus, to great matrix reinforcement, increasing the stiffness and resistance of the films, while decreasing their elongation capacity. Likewise, the polarity reduction and the greater cohesion of the matrix implied lower equilibrium moisture contents in the films and an increase in their water vapour and 
oxygen barrier capacity, as well as a reduction in the water bonding capacity. However, oxidation also provoked a disruption of $S$ chains, mostly appreciable for films containing partially oxidized S (OS), which showed a less cohesive network. Thermal stability was also affected by the chains' fragmentation, leading to a decrease in both $T_{0}$ and $T_{\max }$ for both oxidation degrees of starch. Although oxidation did not causereduction in the overall migration values under the established threshold limit $\left(10 \mathrm{mg} / \mathrm{dm}^{2}\right)$, it was effective at reducing the migration in an acid medium, while increasing it in a $10 \%$ ethanol aqueous medium.

LAE contains carbonyl and amino groups and, due to its bifunctional nature, its incorporation into OS-BG films as antimicrobial agent interfered with the polymer crosslinking reactions. The lower molecular weight of LAE implied an easier reaction with OS instead of gelatin, as well as a higher reaction with the short $S$ chains resulting from oxidation. Consequently, LAE participated in crosslinking reactions but no improvement in the network tightness was observed subsequent to its incorporation. These effects were especially noticeable when partial oxidation was applied, due to the lower amount of $\mathrm{C}=\mathrm{O}$ groups generated. Hence, the films were less stiff and stretchable, and exhibited a greater water binding capacity and higher migration values in aqueous media at neutral $\mathrm{pH}$.

The crosslinking process in Starch BG films led to a more homogeneous structure with increased transparency and gloss. In addition, the reinforcement of the polymeric network enhanced the tensile behaviour of the films and slowed down the mass transport mechanisms throughout the films, by promoting the tortuosity factor. In the same way, the anti-plasticizing effect also promoted a reduction in the permeability values. As commented on above, all of these phenomena were also observed for BM-starch films when blends were thermally treated; this led to the formation of a protein gel during film drying caused by crosslinking of the protein strands above the critical gel concentration, which was favoured by the presence of calcium salts in the medium. Nevertheless, the enhancement of the functional properties that occurred in heated starch-BM blends was lower than that obtained with OS and BG blends. In addition, a progression of crosslinking throughout storage time was observed in the latter case, leading to greater stiffness and barrier properties of the films. Figure D.1 shows a) the map of the elongation, \% E - tensile strength, TS (MPa) and b) the map of OP - WVP of all the film formulations obtained using the different blending strategies, where the aforementioned effects can be observed. 

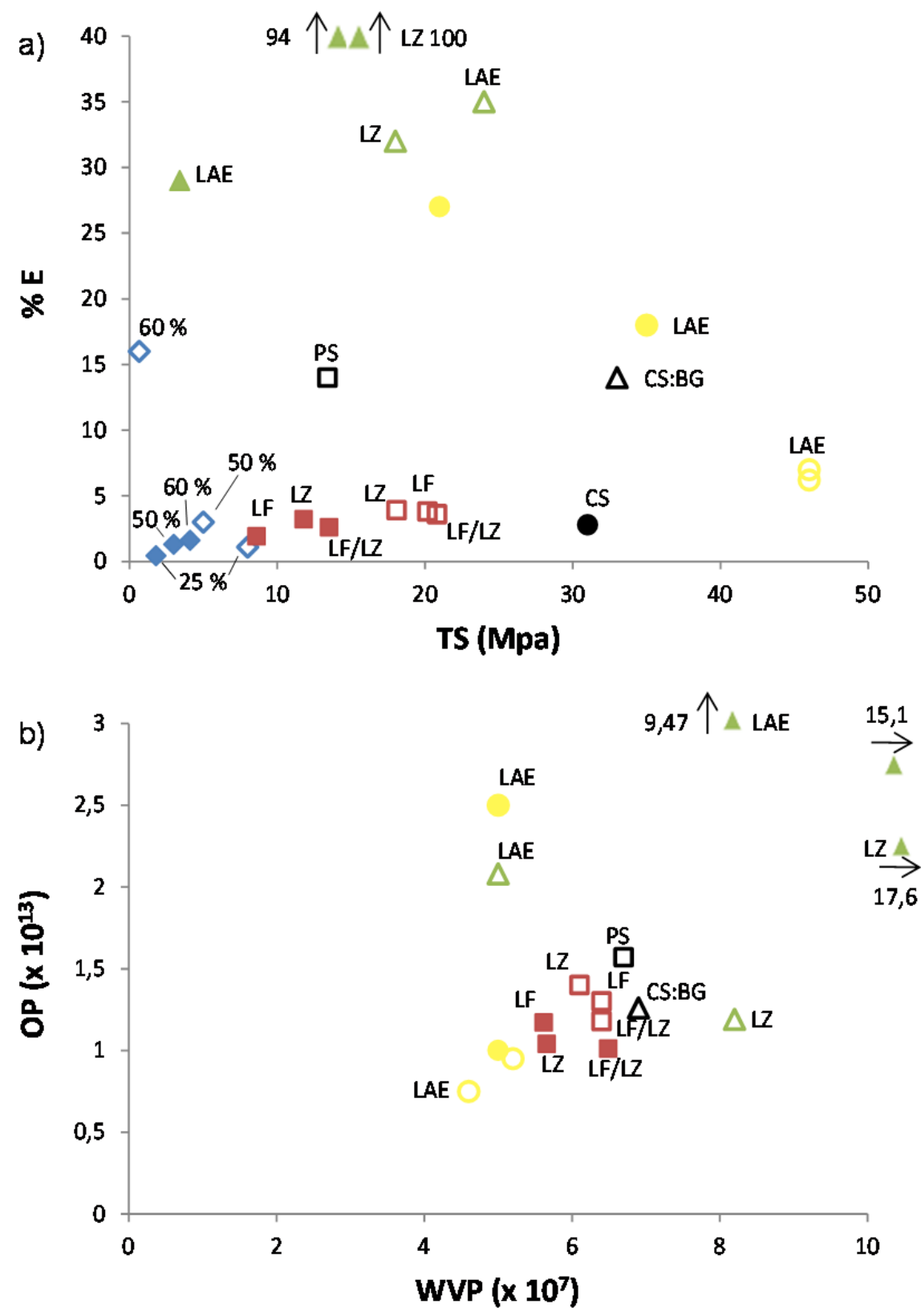

$\diamond \mathrm{BM} \quad \mathrm{LF} / \mathrm{LZ} \triangle \mathrm{LAE} / \mathrm{LZ} \quad$ Oxidized

Figure D.1 a) Map of tensile behaviour and b) map of oxygen permeability, OP $\left(\mathrm{cm}^{3} / \mathrm{m} \mathrm{s}\right.$ $\mathrm{Pa})$, and water vapour permeability, WVP $\left(\mathrm{g} \cdot \mathrm{mm} / \mathrm{kPa} \cdot \mathrm{h} \cdot \mathrm{m}^{2}\right)$ for all the film formulations.

Black marks correspond to net starch film (Corn starch, CS; Potato starch, PS) and CS:BG film. Solid marks correspond to heat treatment (BM), highest proportion of protein, $20 \%$ wt. (LF/LZ), thermoprocessing (LAE/LZ) and partial oxidation (Oxidized starch). 
On the other hand, not only did the protein incorporation affect the film colour, but also the film processing method and $S$ oxidation, which could impact on the consumer acceptability. The changes introduced by BM and LF were coherent with the ratio of incorporation, leading to an increase in colour saturation $\left(\mathrm{C}_{\mathrm{ab}}{ }^{*}\right)$ and a shift towards a yellow and reddish hue, respectively. When BG was blended with $S$, the processing method played a key role in the development of colour; the thermal treatment promoted a reddish coloration, because of the browning reactions. As previously commented on, these dark brown colorations evidenced thermal reactions; hence, thermoprocessing could not represent a convenient strategy with which to obtain S-BG films. LAE incorporation mitigated these effects, whereas LZ enhanced them to a higher extent. As regards the oxidation treatment of $S$, the yellow-brown coloration of the films associated with carbonyl-amino condensation reactions might be attributed to the formation of conjugated Schiff's bases, which are intermediate products of the Maillard reaction. As a result, a decrease in lightness and hue together with an increase in chrome was noticed in oxidized-starch films. Maillard compounds also induced a reduction in internal transmittance $\left(T_{i}\right)$ at low wavelength, between 400 and $500 \mathrm{~nm}$, leading to a decrease in transparency, coherently with the degree of oxidation. The involvement of LAE in the browning reaction was evidenced by a greater reduction in lightness and a strengthening of the brownish hue. As well as the crosslinking effect, the browning of OS-BG films also increased throughout storage time, exhibiting higher chrome and lower lightness; this occurred to a lesser extent when the $S$ oxidation was complete, due to the poorer molecular mobility caused by the higher degree of crosslinking. Figure D.2 shows the chromatic plot of all the films' formulations obtained by using different blending strategies, where the aforementioned effects can be observed. 


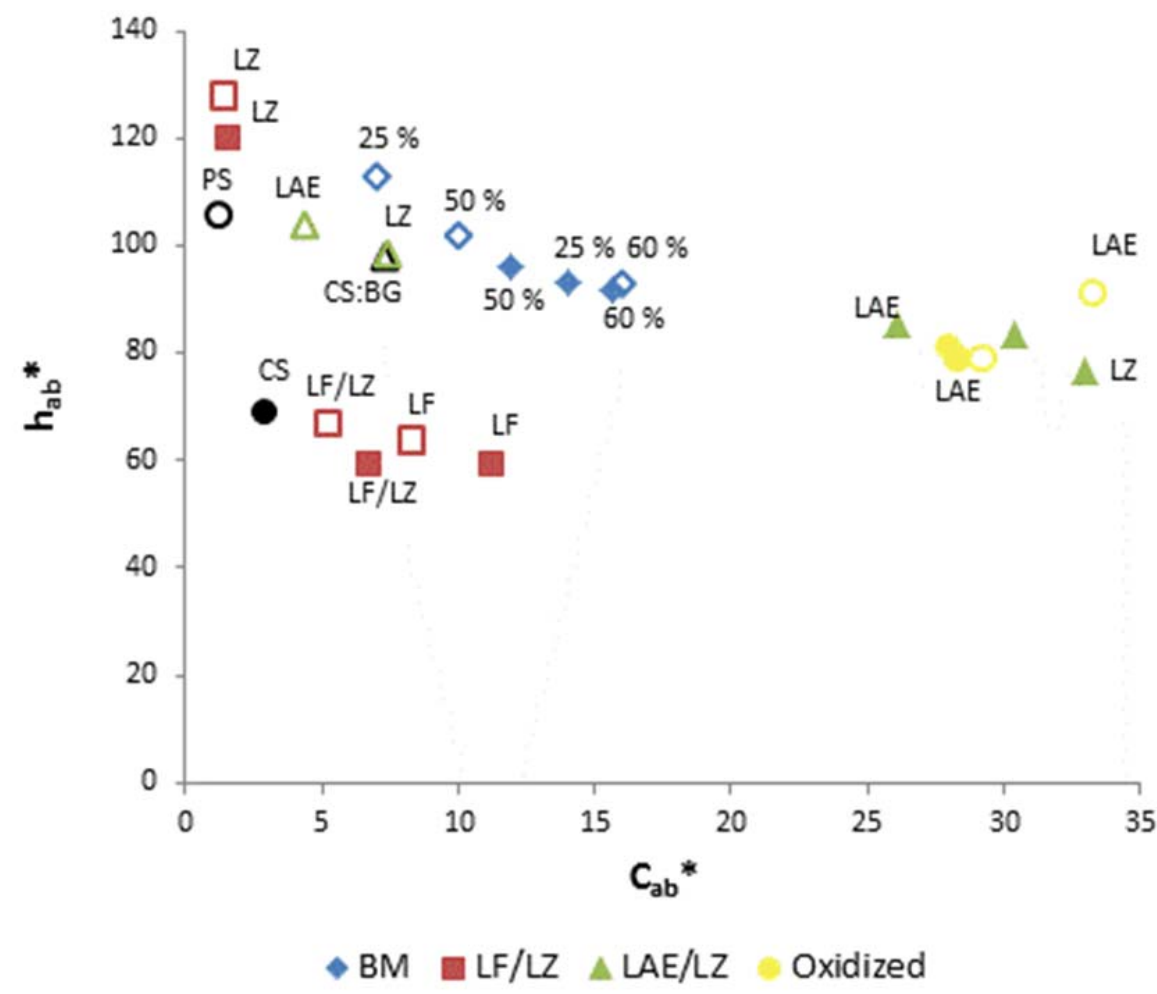

Figure D.2 Chromatic plot for all the film formulations. Black marks correspond to net starch film (Corn starch, CS; Potato starch, PS) and CS:BG film. Solid marks correspond to heat treatment (BM), highest proportion of protein, $20 \%$ wt. (LF/LZ), thermoprocessing (LAE/LZ) and partial oxidation (Oxidized starch).

As concerns the active properties of the films, the antioxidant and antimicrobial capacity was determined by the kind of active agent used in each case. Either solutions of BM or active proteins, such as LF and/or LZ, exhibited antioxidant activity when tested in vitro, the proteins being significantly more active. More specifically, LF showed the lowest trolox equivalent antioxidant capability (TEAC) value, being the most effective antioxidant compound tested in vitro, while no synergistic effect between proteins was observed. When incorporated into the films, BM only exhibited antioxidant activity when it was thermally treated, although the TEAC values were significantly higher than those obtained for their water solutions. Active films containing LF and/or LZ (10 and $20 \% \mathrm{wt}$.) were applied in vivo to preserve pork lard and a decrease in the peroxide value (PV) was found for all samples coated with films with and without proteins, coherently with the low oxygen permeability values of the films. In contrast with that observed in in vitro tests, the samples coated with films containing LF showed the highest PV value, probably due to its content in iron, which could catalyse oxidation in the lard. An antimicrobial analysis 
of the obtained films revealed that BM, LZ and LF were not effective at controlling the growth of Listeria innocua in starch films. The same result was obtained for solutions of LF and LZ; nonetheless, a significant synergistic action was found when applied in combination in vitro against the Gram negative bacterium Escherichia coli. Films containing LF and/or LZ were ineffective against the natural aerobic microbiota in minced pork meat not only when tested in vitro, but also in vivo; however, a synergistic effect at controlling the growth of Coliforms was noticed. A key factor in the active properties of films is the release of the antimicrobials into the food system. This could be the main reason for the low antimicrobial activity of both proteins, since their inhibited diffusion would hinder their action whereas starch coul be a nutrient for the bacteria.

LAE was the strongest antimicrobial compound tested, since its incorporation in S-BG films at $10 \mathrm{wt}$. \% resulted in a total in vitro inhibition of $L$. innocua. In addition, OS:BG without LAE was also effective at controlling $L$. innocua growth in vitro, due to the formation of Maillard compounds, which have been reported to show antimicrobial activity related with their production of hydrogen peroxide. Likewise, the high degree of browning reached in the films throughout storage time was related with a greater inhibition of bacterial growth. The combination of LAE, at $1.3 \%$ wt. in the film, with Maillard compounds in OS-BG films led to a total bactericidal effect in in vitro tests with L. innocua. Despite the strong antimicrobial activity proven in in vitro tests, when films containing LAE were applied for the preservation and extension of the shelf life of chicken breast and marinated salmon fillets, the interactions with the complex food matrices led to a decrease in its antimicrobial capacity, in comparison with the in vitro results. More specifically, OS:BG films with 1.3 wt. \% of LAE, were more effective at controlling natural microbiota growth than L.innocua in marinated salmon. Nonetheless, at the end of the storage time (45 days) the counts were always under the maximum limit of $6 \log \mathrm{CFU} / \mathrm{g}$, in every case. As concerns the preservation of chicken breast fillets, OS:BG films were more effective at controlling all of the microorganisms tested throughout storage time than the thermoprocessed $S: B G$ films, with the same proportion of LAE (10 \% wt.). The combination of LAE and Maillard compounds was more effective at preserving chicken fillets. However, despite its ability at extending the shelf life, $O S: B G$ films, either with or without LAE, were not effective at maintaining either the oxidation levels or the colour properties of the food,. As previously commented on, Maillard compounds are able to produce hydrogen peroxide, which, in addition to its antimicrobial ability, might promote lipid oxidation. 


\section{CONCLUSION}

1. Microstructural analysis of starch-buttermilk blend films revealed a reduced compatibility between the starch and milk proteins, leading to phase separation and a heterogeneous structure where lipid droplets can also be observed. Heating the buttermilk implied structural differences and the protein phase interpenetrated the starch matrix when there are $60 \%$ of BM in the film. Incorporation of BM to starch films provoke a significant decrease in film stiffness and resistance to break without notable changes in film stretchability, except for $60 \%$ non-heated BM, when films become more extensible but very soft. BM slightly promotes WVP of the starch films and imparted them a more saturated yellowness, reducing their gloss when not heated, but increasing it when heated. Only films containing heated BM showed antioxidant activity, which is attributed to the active peptides released during thermal-homogenization treatments. Buttermilk did not exhibit antimicrobial activity against Listeria innocua, probably due to the low proportion of antimicrobial compounds or to the difficulties involved in their release into the culture medium. Despite its high protein content, with potential antioxidant or antimicrobial properties, BM is not appropriate to formulate starch film due to the negative effect of the other solids present in the commercial powder on the film properties.

2. The incorporation of antimicrobial proteins (lactoferrin and/or lysozyme) had an impact on the structural and physical properties of potato starch films and affected their thermal behaviour by increasing the glass transition temperature. Both proteins showed a certain degree of compatibility with starch chains through the bond formations which increased the Tg values, while a part separates and migrates to the film surface, there giving rise to globular heterogeneous formations. The incorporation of proteins, especially lactoferrin, greatly increased the film's brittleness, regardless of the film's water content, although they enhanced the water vapour and oxygen barrier properties. The protein also reduced the film's transparency and gloss, while lactoferrin induced colour changes, associated with its selective light absorption. The thermal degradation of blend films and isolated proteins occurred at temperatures of over $250{ }^{\circ} \mathrm{C}$, which means that starch-protein 
blends can be thermoprocessed according to the starch's thermoplastic properties and following the usual practices of the plastics industries. The films containing a blend of lactoferrin and lysozyme reduced the total coliform counts in minced pork meat, but did not show significant antimicrobial activity against L. innocua and E. coli. Nevertheless, all the films were effective at reducing lard oxidation after long storage times. Studies into the release kinetics of the bioactive proteins or peptides in food systems are required to establish the usefulness of both LF and LZ in developing biodegradable and bioactive packaging materials.

3. Whereas the incorporation of LAE to starch-gelatin blend films was very effective at imparting active (antilisterial) properties to the material, LZ did not confer notable antibacterial activity on the films. LAE also improved the interfacial adhesion of the polymers in both casting and thermoprocessing methods, making the blending process easier. The incorporation of LAE notably reduced stiffness and resistance to break in casting films, making them more extensible, which was only observed for $L Z$ in the case of the casting method. Likewise, LAE promoted water vapor barrier properties and increased the oxygen permeability of the films, although the latter was in the range of food packaging requirements. Likewise, this antimicrobial compound enhanced the thermal stability of the blends, which is highly positive for thermoplastic processing at industrial level. Therefore, as it is a promising compound when formulating biodegradable active films obtained by either casting or thermal processing, its incorporation into starch-gelatin films greatly enhanced their functionality and added value. Nevertheless, due to the fact that there is a high degree of overall migration of the films to hydrophilic food simulants, different strategies, such as the crosslinking process, would be required to limit this aspect.

4. Starch oxidation with sodium periodate greatly promoted crosslinking in starch-gelatin (1:1) films, enhancing the films' strength and oxygen and water vapour barrier capacity, while reducing their water uptake capacity and migration to acid media. A glucose:periodate molar ratio of 1:1 was more effective than 1:0.5, due to the greater progress of di-aldehyde formation, which offers more reactive groups for the aminocarbonyl reaction and the formation of inter-chain bonds between polysaccharides and proteins. Incorporating $\mathrm{LAE}$ as an antimicrobial compound interferes with the polymer crosslinking reactions due to its bifunctional nature: it contains carbonyl and amino 
groups which also react with the polymer chains, especially when there is an intermediate degree of starch oxidation. This affected the tensile behaviour of the films, which were less stiff and stretchable. Nevertheless, an amino-carbonyl condensation reaction also provoked browning in the films, in line with the formation of Maillard compounds. This browning, as well as crosslinking, progressed in the film network throughout storage, especially in partially oxidized starch films, which could compromise their application for certain uses. Nevertheless, the Maillard compounds formed could confer active properties on the films due to their antimicrobial capacity.

5. Oxidized starch-gelatin blend films, with and without LAE, were highly effective at controlling microbial growth, exhibiting antilisterial activity in marinated salmon samples, greatly extending the product shelf life in terms of microbial spoilage. However, the films exhibited high values of water vapour permeability, which implied a weight loss of about $10 \%$ in salmon samples packaged for 45 days. The films exhibited browning mainly when stored at a high relative humidity or when containing LAE due to the carbonylamino reactions and the formation of Maillard compounds, which have antimicrobial activity. These reactions progressed during storage, increasing the antimicrobial power. LAE incorporation provoked a total bactericidal effect when tested in vitro against Listeria innocua, although it was not effective in marinated salmon where the antilisterial effect was similar for films with and without LAE. The TVC in salmon samples remained below the legal limit after 45 storage days, which would allow for an extended shelf-life. However, salmon samples underwent darkening in line with desiccation, which affects their quality. Therefore, a multilayer film, with good water vapour barrier properties, would be necessary in order to extend the shelf life in a wider concept, including all of the quality parameters.

6. Films of S-G containing LAE greatly enhanced the shelf life of chicken breast fillets. The microbiological limit of acceptability for TVC was reached at 16 or 12 days of storage when chicken breast fillets were packaged in TP films containing or not LAE, respectively. This represented a notable increase (4 days) of the shelf life of chicken breast fillets compared to samples packaged in non-active films (TP_C). Those films containing oxidised starch $(\mathrm{OC})$ without LAE also showed antimicrobial activity, extending shelf life of the fillets 4 days when compare to non-active TP_C films. Nevertheless, OC_LAE films were the most effective at controlling microbial growth (the microbial limit was not reached in 19 storage days), but the presence of pro-oxidant 
compounds in $\mathrm{OC}$ films promoted lipid oxidation, which, in turn, affected the colour of the samples. Therefore, in samples packaged in OC films the critical parameter to define shelf life of the chicken breast fillets was the oxidation level. The limit of acceptability of $1.5 \mathrm{mg} \mathrm{MDA} / \mathrm{kg}$ was reached after 9 days of storage. So, despite of the higher antimicrobial effectiveness of OC films, this material is not recommended as packaging material for preservation of oxidation sensitive foodstuffs. Overall, starch-gelatine TP films containing LAE have the potential to be used as antimicrobial packaging material to significantly increase the shelf life of chicken breast fillets during chilled storage.

\section{Final remark}

Starch protein blend films with with antimicrobial properties represent a good pacakaging stragety to extend shelf-life of perishable foods such as meat or fish products because of their edible character and their ability for contact porpouses. Nevertheless, their water uptake capacity and poor water vapor barrier properties, still represet a hurdle for their use. Multilayer films combining starch-protein films with more hydrophobic materials coud be used to mitigate this issue. Starch oxidation and crosslinking promotion reduced water absorption capacity of the films, giving them antimicrobial activity, but induce the presence of pro-oxidant compounds, which can enhace deterioration of foodstuffs sensitive to oxidative processes. 
